\title{
6. MIDDLE MIOCENE TO QUATERNARY DIATOM BIOSTRATIGRAPHY IN THE NANKAI TROUGH AND JAPAN TRENCH, AND MODIFIED LOWER MIOCENE THROUGH QUATERNARY DIATOM ZONES FOR MIDDLE-TO-HIGH LATITUDES OF THE NORTH PACIFIC ${ }^{1}$
}

\author{
Fumio Akiba, Central Technical Laboratory, Japan Petroleum Exploration Company²
}

\begin{abstract}
During Leg 87 of the Deep Sea Drilling Project, eleven holes were drilled at Sites 582 and 583 in the Nankai Trough, off Shikoku, southwestern Honshu, and three holes at Site 584 in the Japan Trench, off northeastern Honshu, Japan. In the former area, a low-latitude diatom zone called the Pseudoeunotia doliolus Zone is recognized in thick upper Quaternary sediments, which yield rare but characteristic admixtures of marine planktonic, marine tychopelagic-tobenthic, and nonmarine diatoms. In the latter area, all the sediments recovered contain abundant to common diatoms, allowing recognition of 12 continuous diatom zones from upper Quaternary through lower middle Miocene. Three hiatuses occur in this area around the Pleistocene/Pliocene boundary and in the upper and middle Miocene. In addition, 19 modified diatom zones for a lower Miocene through upper Quaternary interval are proposed. These middle-to-highlatitude zones are numerically coded (NPD1-NPD12) and represent the entire North Pacific. The establishment of these zones is based primarily on Leg 87 data and other DSDP materials and partially on several Japanese subaerial sequences. Correlation of the new zonal framework with previously established frameworks is attempted by the evaluation of operational usefulness of previously used datums. Resting spores of Chaetoceros and its related forms are recorded with specific intent for the first time, and possible ramifications of its frequency variation are presented.

Nine new species are proposed: Delphineis sheshukovae Akiba n. sp., Denticulopsis praelauta Akiba and Koizumi n. sp., Kisseleviella ezoensis Akiba n. sp., Nitzschia umaoiensis Akiba n. sp., Thalassiosira jouseae Akiba n. sp., T. praenidulus Akiba n. sp., T. sancettae Akiba n. sp., T. umaoiensis Akiba n. sp., and T. urahoroensis Akiba n. sp. Transfers of systematic positions of the following four taxa are also proposed: Delphineis simonsenii (Mertz) Akiba $\mathrm{n}$. comb., Ikebea tenuis (Brun) Akiba n. comb., Thalassiosira delicata (Barron) Akiba n. stat., and Thalassiothrix robusta (Schrader) Akiba n. comb.
\end{abstract}

\section{INTRODUCTION}

During Leg 87,14 holes were drilled at three sites in two different trench complexes off Japan, the Nankai Trough off Shikoku, southwestern Japan (Sites 582 and 583) and the Japan Trench, off the northeastern end of Honshu (Site 584) (Fig. 1). Neogene diatom biostratigraphies of both areas had been thoroughly investigated by studies of three previous DSDP cruises, Leg 31 for the Nankai Trough (Koizumi, 1975a) and Legs 56 and 57 for the Japan Trench (Harper, 1980; Barron, 1980a).

In the Nankai Trough area, where the low-latitude diatom zonation of Burckle $(1972,1977)$ is applicable for biostratigraphic subdivision, thick upper Quaternary to upper Pliocene sediments were recovered. Diatoms, however, are generally rare and usually occur in the upper Quaternary interval. Diatoms are not very age diagnostic in this area compared with other microfossils; diatoms rarely occur, and abundant displaced diatoms including both marine tychopelagic-to-benthic and nonmarine forms lowered the relative frequencies of marine planktonic diatoms that are useful for biostratigraphy.

In the Japan Trench area, on the other hand, very abundant to common diatom remains are present in all the sediments recovered. Those sediments range from

\footnotetext{
${ }^{1}$ Kagami, H., Karig, D. E., Coulbourn, W. T., et al., Init. Repts. DSDP, 87: Washington (U.S. Govt. Printing Office).

2 Address: Central Technical Laboratory, Japan Petroleum Exploration Co., Ltd., 3-5-5, Midorigaoka, Hamura-cho, Nishitama-gun, Tokyo 190-11, Japan.
}

upper Quaternary to lower middle Miocene. Three possible hiatuses are recognized: one at the Pleistocene/Pliocene boundary, a second within upper upper Miocene, and a third in the middle Miocene. In this area, the middle-to-high-latitude diatom zonation, initially established by Koizumi $(1973 \mathrm{a}, \mathrm{b})$, is applicable to the recovered sediments.

The zonation of Koizumi (1973a, b) was modified or revised several times by subsequent workers, including Koizumi himself, because of the introduction of newly found, biostratigraphically useful diatom species or differing concepts of the specific datum levels (Koizumi, 1975c, 1977, 1979; Barron, 1980a, 1981, in press a; Akiba et al., 1982; Akiba, 1982a; Akiba and Ichinoseki, 1983; Maruyama, 1984). As a result of such modifications and revisions, Neogene diatom biostratigraphy for this region has been refined further and biostratigraphic resolution has increased considerably. On the other hand, confusion has increased recently because of different definitions of diatom zones bearing the same names or the assignment of the same interval to different zones by different investigators. This situation obscures regional correlation of Neogene diatomaceous sequences and also might prevent usage of diatom zones by nonspecialists. Especially, zonations of middle Miocene to upper Miocene intervals proposed by Akiba and others (1982), Akiba (1982a), and Maruyama (1984) use a zonal system that differs from both Koizumi's and Barron's zonations. Unification of these different zonations, or at least a clear correlation between them, is desirable. To 

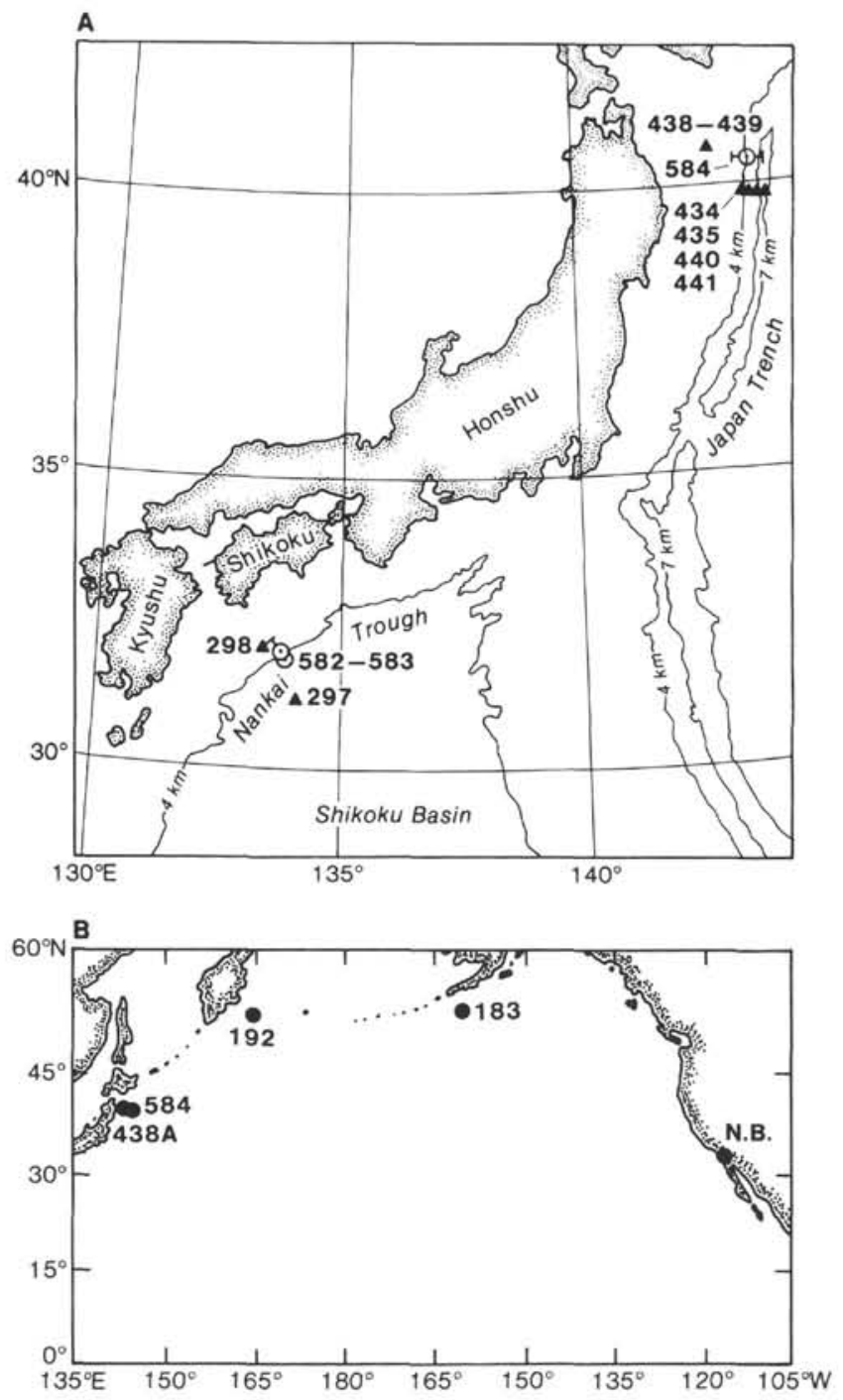

Figure 1. Location of Sites 582 and 583 in the Nankai Trough and Site 584 in the Japan Trench (A), and other sections discussed or referred to in this chapter (B); numbers refer to DSDP sites; N. B. is the Newport Beach Section, California.

some extent these problems are answered in this chapter by the evaluation of diatom datums used by different authors.

The zonation used in this chapter (Fig. 2) is basically the same as those presented by Akiba and others (1982), Akiba (1982a), and Akiba and Ichinoseki (1983), with the incorporation of a few modifications suggested by Maruyama (1982) and Barron (in press a) and the introduction of three new zones for the Miocene interval. The Pliocene and Pleistocene zonations basically follow those of Koizumi (1973a, b). Although many different zone names from either Koizumi (1973a, b) or Barron (1980a, in press a) are used here, datums used in this chapter are almost identical to those of Barron (1980a, in press a), with a very few exceptions. As a result, 19 modified Neogene diatom zones ranging from the lower Miocene through Pleistocene were easily recognized for the middle-to-high latitudes of the North Pacific. All

\begin{tabular}{|c|c|c|c|c|}
\hline 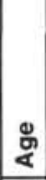 & 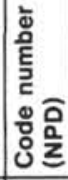 & Diatom zone & Boundary datum & Ma \\
\hline \multirow{3}{*}{ 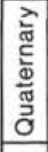 } & 12 & Neodenticula seminae & \multirow{2}{*}{$\begin{array}{l}\text { - L R. curvirostris } \\
\text {-L A. oculatus }\end{array}$} & \multirow{2}{*}{0.25} \\
\hline & 11 & Rhizosolenia curvirostris & & \\
\hline & 10 & Actinocyclus oculatus & Thalassiosira & 0.9 \\
\hline \multirow{3}{*}{ 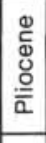 } & 9 & Neodenticula koizumii & - - antiqua & 1.7 \\
\hline & 8 & N. koizumii-N. kamtschatica & - L N. kamtschatica & 2.4 \\
\hline & $7 \mathrm{~B}$ & Neodenticula kamtschatica & . kolzumil & 3.2 \\
\hline \multirow{5}{*}{ 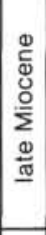 } & $7 \mathrm{~A}$ & Rouxia californica & calliornica & 6.0 \\
\hline & $6 B$ & Thalassionema schraderi & schraderi & 7.4 \\
\hline & $6 \mathrm{~A}$ & Denticulopsis katayamae & 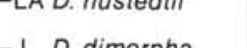 & 9.0 \\
\hline & $5 \mathrm{D}$ & Denticulopsis dimorpha & amorpna & 10.4 \\
\hline & $5 \mathrm{C}$ & Thalassiosira yabei & . aimorpiad & 11.0 \\
\hline \multirow{4}{*}{ 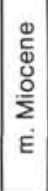 } & $5 B$ & Denticulopsis praedimorpha & D. praedimorphá & 12.1 \\
\hline & $5 \mathrm{~A}$ & Crucidenticula nicobarica & D. praedimorpha & 13.3 \\
\hline & 4B & Denticulopsis hyalina & FA D. hustedtii & 13.9 \\
\hline & $4 \mathrm{~A}$ & Denticulopsis lauta & 6. туатыс & (1) \\
\hline \multirow{4}{*}{ 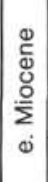 } & 3B & Denticulopsis praelauta & 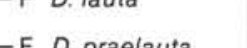 & \\
\hline & $3 A$ & Crucidenticula kanayae & D. Prdelacta & 10.4 \\
\hline & 2 & Thalassiosira fraga & & 10.0 \\
\hline & 1 & Thalassiosira spinosa & 1. $1 \mathrm{rat}$ & 19.0 \\
\hline
\end{tabular}

Figure 2. Modified Neogene diatom zonation for the middle-to-high latitudes of the North Pacific and its corresponding code numbers. $\mathrm{L}=$ last occurrence, $\mathrm{LA}=$ last abundant occurrence, $\mathrm{F}=$ first occurrence, $\mathrm{FA}=$ first abundant occurrence.

zones, except for the lowermost Thalassiosira spinosa Zone, were recognized in several DSDP sites off northeastern Honshu (Harper, 1980; Barron, 1980a; Akiba et al., 1982; Maruyama, 1984) and also in many on-land sequences of Honshu and Hokkaido (e.g., Tsuchi et al., 1979; 1981a, b). Neogene North Pacific diatom zone (NPD) code numbers are assigned to each zone for easy reference by researchers unfamiliar with diatom biostratigraphy. Originally proposed by Barron (in press a), the code numbers are basically followed in this report with only slight modifications. Letters A to D following several code numbers do not necessarily indicate subzones but are used to help correlate diatom zonations of this chapter with those of either Koizumi or Barron.

In addition, occurrences of resting spores of the genus Chaetoceros and its closely related forms are recorded and its new implications are suggested. These spores have not been treated fully in previous reports.

Several important taxonomic changes of zonal marker species used in this chapter (for example, revision of the genus Denticulopsis Simonsen into Crucidenticula Akiba and Yanagisawa, Denticulopsis emend., and Neodenticula Akiba and Yanagisawa) are treated separately by Akiba and Yanagisawa (this volume). 


\section{METHODS}

Samples for diatom analysis ( $\sim 1$ to $3 \mathrm{~cm}^{3}$ each) were taken aboard the Glomar Challenger from every section of Leg 87 cores. One sample per core was examined first, and samples from more closely spaced intervals were investigated between levels of significant floral change. In addition, selected samples from Sites 183 and 192 of Leg 19 (Koizu$\mathrm{mi}, 1973 \mathrm{a}$ ) and Sites 438A and 439 of Leg 57 (Barron, 1980a) were reexamined in order to check either the applicability of several newly proposed diatom zones for these sites or the relative abundances of low-latitude species reported at Site 438A by Barron (1980a). Several samples from on-land Neogene sequences in Japan were also examined in order to recover well-preserved diatom specimens suitable for describing some Miocene taxa, because the Miocene interval encountered at Leg 87 sites generally yielded rather poorly preserved diatom assemblages.

Unprocessed strewn-slides were prepared (after Akiba, 1982a, b) by placing $\sim 1 \mathrm{~g}$ of wet sample into a $100-\mathrm{ml}$ beaker and then adding $\sim 20 \mathrm{ml}$ of boiling distilled water. After the distilled sample had soaked overnight, more distilled water was added to obtain a solution of suitable density. The solution was left for $-20 \mathrm{~s}$ in order to let grains denser than diatoms, such as grains of quartz, settle to the bottom of the beaker. An $18 \times 18-\mathrm{mm}$ cover slip and a Pleurax mounting medium were used to prepare slides from the solution (generally without any further cleaning). Slides for taxonomic purposes were prepared following the method of Koizumi (1968).

One hundred diatom valves were counted for each sample at $500 \times$ magnification, except for Hole 438A, where 300 valves were counted at $1250 \times$ magnification. After the counting, the slides were scanned to record the presence of other diatom species missed in the original tally. More than 200 and usually almost 1000 diatom valves were observed for samples containing sufficient diatom remains. In general, for those samples that contained fewer than 100 diatom valves per slide, all the diatom valves on each slide were counted. Identifications of diatoms were checked at $1250 \times$ magnification.

A single diatom valve is counted as one when more than one half of a valve is observed; other criteria for identifying specific genera are given by Schrader and Gersonde (1978). A few exceptions, however, are adopted here. Broken specimens of Thalassionema and Thalassiothrix species are counted as one valve when two apices are observed, and intercalary bands of either Denticulopsis dimorpha or D. praedimorpha are included in the count, because they are morphologically unique and resistant to dissolution and because previous authors (e.g., Schrader, 1973a, b; Barron, 1980a, 1981) regarded them as complete valves. Relative frequencies of these two species, therefore, are slightly exaggerated compared to other diatoms. Resting spores of Chaetoceros and its allied forms are counted separately during the routine 100 count of diatom valves.

Diatom abundance is indicated as $\mathrm{R}$ (rare, less than 100 diatom valves per slide); F (few, 101-1000 valves); C (common, 1001-3000 valves); and A (abundant, more than 3000 valves), and their state of preservation is recorded as P (poor), M (moderate), and G (good) based on the degree of breakage and dissolution of diatom valves. Nearly all the diatom species are tabulated, but several species that occur only very sporadically and are not important for biostratigraphic or paleoceanographic studies are included as "miscellaneous" in the occurrence chart.

\section{BIOSTRATIGRAPHY}

\section{Site $\mathbf{5 8 2}$}

Three holes were drilled at Site 582, located in the Nankai Trough off Shikoku Island, about $2 \mathrm{~km}$ south of a deformation front, where thrusting associated with subduction begins. They are Hole 582, Hole 582A, and Hole 582B (for all three holes: $31^{\circ} 46.51^{\prime} \mathrm{N}, 133^{\circ} 54.83^{\prime} \mathrm{E}$; water depth $4879 \mathrm{~m}$ ). One of the main objectives of drilling at both Nankai Trough Sites 582 and 583 was to investigate changes in the physical and mechanical properties of sediments during subduction. Drilling problems allowed recovery of only four and two cores from Holes 582 and 582A, respectively, but in Hole 582B upper Quaternary trench-fill sediments (approximately $560 \mathrm{~m}$ thick) overlying lower Quaternary and upper Pliocene hemipelagites were penetrated to a depth of $749.4 \mathrm{~m}$. Occurrences of diatoms are restricted to upper Quaternary turbidite intervals at this site.

Abundance of diatoms ranges from common to rare in most of the samples from Holes 582, 582A, and 582B (Table 1). Abundance varies with almost no general relation to increasing sub-bottom depth, except for a sudden decrease near Sample 582B-42,CC, also noted by sedimentologic analysis. Samples 582B-51-1, 93-94 cm through 582B-73-1, 58-59 cm contain either very few diatom remains (mostly moderately-to-poorly preserved fragments of Coscinodiscus spp.) or are barren. Therefore, their occurrences are not shown in Table 1.

Three samples from Holes 582 and $582 \mathrm{~A}$, and samples from 582B-2-1, 127-129 cm through 582B-50-1, $99-100 \mathrm{~cm}(518.80 \mathrm{~m})$ belong to the upper Quaternary Pseudoeunotia doliolus Zone (0-0.64 Ma) of Burckle $(1972,1977)$ based on the occurrence of $P$. doliolus and no consistent occurrence of Nitzschia reinholdii. We have interpreted the very sporadic occurrences of the latter species in a few samples of Hole 582B to be reworked specimens.

Diatom assemblages encountered in these holes represent three different habitats: marine planktonic, marine tychopelagic to benthic, and nonmarine. The first group is predominant. Most specimens of the latter two groups were evidently displaced to the site by turbidity currents. Among these marine tychopelagic-to-benthic diatoms, Paralia sulcata occurs consistently and in some samples very abundantly (over $20 \%$ ). Most, but not all, of these occurrences are displaced ones, because the species is also frequently found in modern planktonic flora of the area. Nonmarine diatoms are recognized in all the samples examined, and their abundance in several samples accounts for more than $30 \%$ of the total assemblage. Nonmarine diatoms are generally better preserved than marine ones. Marine planktonic species consist predominantly of warm-water extant forms such as Coscinodiscus nodulifer, Nitzschia marina, Pseudoeunotia doliolus, Rhizosolenia bergonii, and Thalassiosira lineata. No typical cold-water forms were found in any of the samples examined. Consequently, the low-latitude diatom zonation of Burckle $(1972,1977)$ was applied to these holes instead of the middle-to-high latitude scheme (e.g., Koizumi, 1973a, b; Barron, 1980a, in press a; and this chapter).

\section{Site $\mathbf{5 8 3}$}

Across the lowest structural terrace of the landward slope of the Nankai Trough, off Shikoku Island, eight holes were drilled at Site 583. They are Hole $583\left(31^{\circ}\right.$ $50.0^{\prime} \mathrm{N}, 133^{\circ} 51.4^{\prime} \mathrm{E}$; water depth $4634 \mathrm{~m}$ ); Hole 583A $\left(31^{\circ} 50.18^{\prime} \mathrm{N}, 133^{\circ} 51.26^{\prime} \mathrm{E}\right.$; water depth $\left.4618 \mathrm{~m}\right)$; Holes 583B and $583 \mathrm{C}\left(31^{\circ} 49.8^{\prime} \mathrm{N}, 133^{\circ} 51.26^{\prime} \mathrm{E}\right.$; water depth $4677 \mathrm{~m})$; Hole $583 \mathrm{D}\left(31^{\circ} 49.76^{\prime} \mathrm{N}, 133^{\circ} 51.54^{\prime} \mathrm{E}\right.$; water depth $4676 \mathrm{~m})$; Holes $583 \mathrm{E}$ and $583 \mathrm{~F}\left(31^{\circ} 50.1^{\prime} \mathrm{N}, 133^{\circ}\right.$ $51.3^{\prime} \mathrm{E}$; water depth $\left.4629 \mathrm{~m}\right)$; and Hole $583 \mathrm{G}\left(31^{\circ}\right.$ $50.07^{\prime} \mathrm{N}, 133^{\circ} 51.4^{\prime} \mathrm{E}$; water depth $4627 \mathrm{~m}$ ). Holes 583 , 583E, and 583F reached $439.7 \mathrm{~m}$ sub-bottom depth; Holes 
Table 1. Stratigraphic occurrence of diatoms in Holes 582, 582A, and 582B.

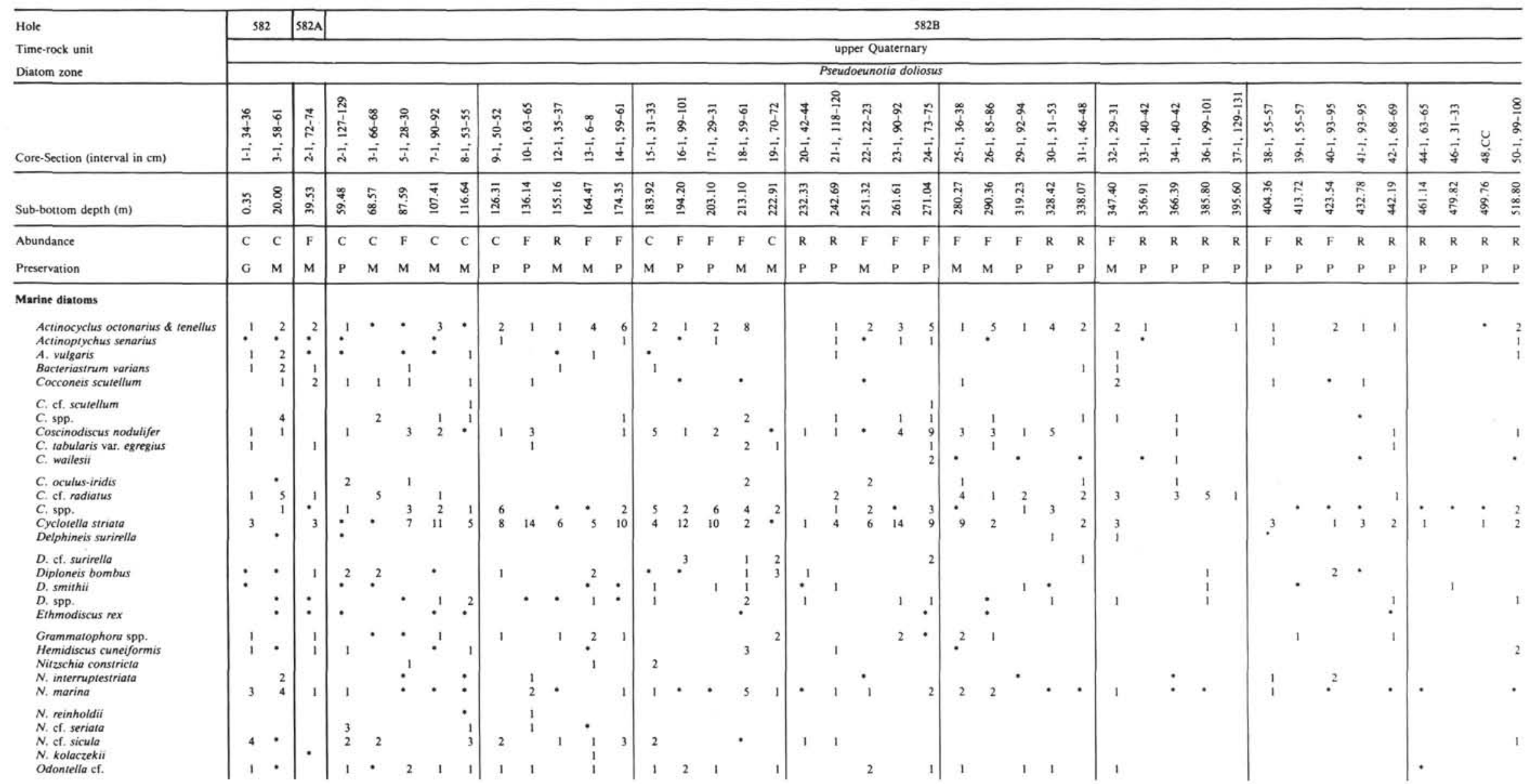




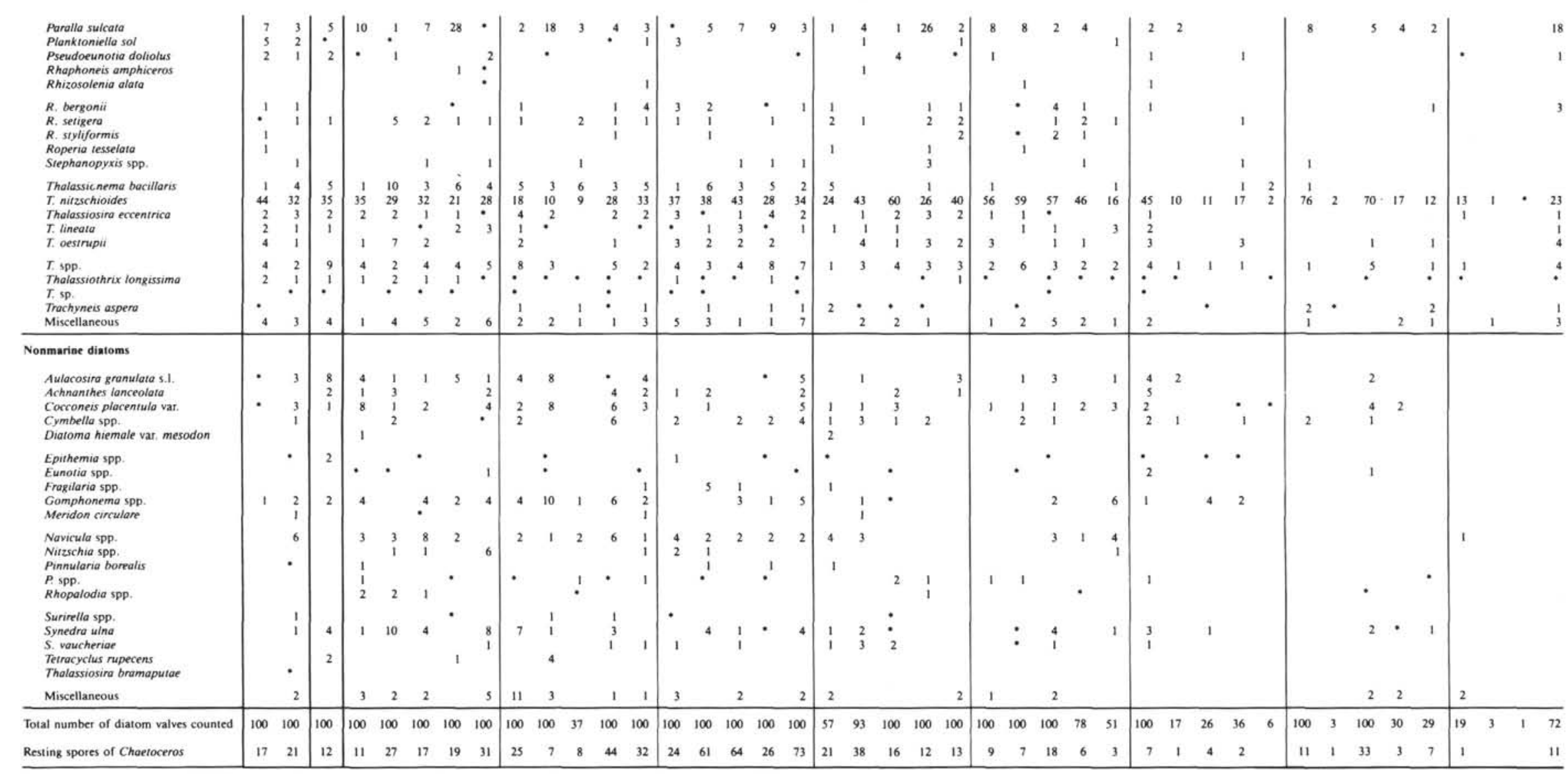

Note: Numbers represent either individuals in routine 100 count or total ones in a single mount; ${ }^{*}$ indicates presence of taxa. See Figure 2 for complete names in diatom zones. 
583B, 583C, and 583D reached $326.6 \mathrm{~m}$; and Hole 583G reached $450.7 \mathrm{~m}$ sub-bottom depth. All the recovered sediments from those holes are Quaternary, and most are turbidites.

Diatoms are recognized in all the samples examined from the seven holes at Site 583; their abundance and preservation vary (Tables 2 and 3 ). In Holes 583 through $583 \mathrm{D}$, diatoms are mostly few to common, and in a few cases diatoms are rare. Their preservation is moderate to poor. In Holes $583 \mathrm{~F}$ and $583 \mathrm{G}$, diatoms are rare to very rare, and their preservation is poor.

All the samples from Holes 583 through 583D belong to the upper Quaternary Pseudoeunotia doliolus Zone of Burckle $(1972,1977)$. Isolated occurrences of Nitzschia reinholdii recognized in a few samples from Hole 583 are evidently reworked specimens. The interval from 583F-6-1, 60-62 cm (199.31 m sub-bottom) through $583 \mathrm{~F}-25-1,124-126 \mathrm{~cm}(383.03 \mathrm{~m})$ is also assigned to the above $P$. doliolus zone, but the underlying interval, $583 \mathrm{~F}-26-1,122-123 \mathrm{~cm}$ through $583 \mathrm{~F}-29-1,47-48 \mathrm{~cm}$, lacks zone-diagnostic or age-diagnostic diatoms. Similarly samples from Hole $583 \mathrm{G}$ cannot be assigned to any diatom zones, because age-diagnostic diatoms are absent.

Floral composition of diatoms from the Site 583 holes is essentially uniform and practically identical to that from Site 582. They are composed of admixtures of marine planktonic, marine tychopelagic-to-benthic, and nonmarine diatoms. Most of the diatoms in the latter two categories are presumably displaced specimens. Their presence supports turbidite origin of these sediments. Nonmarine diatoms occur throughout the cored sequences in these holes in varying numbers. Their abundance ranges from a few specimens in most cases to as much as $15 \%$ of the total assemblage, but in Hole $583 \mathrm{~A}$ very abundant nonmarine diatoms $(20-40 \%)$ are encountered in an interval between 583A-2-1, 112-113 cm $(5.13 \mathrm{~m})$ and $583 \mathrm{~A}-8-1,90-91 \mathrm{~cm}(34.91 \mathrm{~m})$. In addition to diatoms representing the above two habitats, it is probable that even a portion of the marine planktonic diatoms are displaced. Taira (this volume) suggested that the upper Quaternary turbidite sediments recovered at Sites 582 and 583 may have been transported from Suruga Bay, about $600 \mathrm{~km}$ northeast of these sites, to the Nankai Trough. Floral compositions of living marine planktonic diatoms recognized in Suruga Bay are not essentially different from those encountered at Sites 582 and 583 (Akiba, unpublished data). Therefore, even if Taira's suggestion is correct, at this point we cannot differentiate indigenous diatoms at these sites from displaced diatoms that possibly originated in Suruga Bay.

\section{Site $\mathbf{5 8 4}$}

Site 584 (Hole 584: $40^{\circ} 28.0^{\prime} \mathrm{N}, 143^{\circ} 57.1^{\prime} \mathrm{E}$; water depth $4078 \mathrm{~m}$ ) was drilled $42.5 \mathrm{~km}$ upslope from the midslope terrace of the Japan Trench, off northernmost Honshu. Among the objectives at this site were the calibration of Neogene subsidence history; the establishment of a high-resolution stratigraphy using biostratigraphy and paleomagnetics; a test of the nature of a deep seismic reflection presumed to mark a Cretaceous un- conformity, and a better understanding of the tectonic processes affecting slope sediments. Because of persistent caving near $900 \mathrm{~m}$ sub-bottom depth in the three holes (Holes 584, 584A, and 584B), the deep unconformity could not be reached. However, a nearly complete lower middle Miocene through lower Pliocene section, which showed an unexpected structural geometry at lower horizons, was recovered at this site. A thin Quaternary sequence unconformably overlies the lower Pliocene.

Diatoms occur consistently throughout the sequence with varying abundance and preservation, allowing continuous zonal assignments by diatoms at this site. In general, Quaternary sediments yield abundant to common diatoms, which are moderately preserved to well preserved, and lower Pliocene through upper Miocene sediments contain abundant to common diatoms with good to moderate preservation. Abundance and state of preservation of diatoms decline abruptly in the middle of the upper Miocene, and in the lower half of the upper Miocene through middle Miocene, common to few diatoms with poor preservation were recognized.

\section{Hole 584}

Eleven diatom zones from the Neodenticula seminae Zone (NPD12; upper Quaternary) through the Denticulopsis lauta Zone (NPD4A; middle Miocene) were recognized in the $941 \mathrm{~m}$ continuous section cored from Hole 584 (Tables 4-7). Two upper Pliocene zones (the Neodenticula koizumii Zone [NPD9] and the N. koizumii-N. kamtschatica Zone [NPD8]) and the middle middle Miocene Crucidenticula nicobarica Zone (NPD5A) represent hiatuses at this hole (Fig. 3).

Quaternary diatoms were recovered from Samples 584-1-1, 0-3 cm through 584-1-3, 3-5 cm. Samples 584$1-1,0-3 \mathrm{~cm}$ and $584-1-1,83-85 \mathrm{~cm}$ belong to the $N$. seminae Zone (NPD12), of which the base is marked by the last occurrence of Rhizosolenia curvirostris between Samples 584-1-1, 83-85 cm and 584-1-2, 83-85 cm. Samples 584-1-2, 83-85 $\mathrm{cm}$ and 584-1-3, 3-5 $\mathrm{cm}$ are assigned to the $R$. curvirostris (NPD11) and Actinocyclus oculatus zones (NPD10), respectively. The zonal assignment of the latter is tentative because of the lack of $R$. curvirostris in the sample. The very thin Quaternary interval (about $4.3 \mathrm{~m}$ thick) in this hole is characterized by such diatoms as A. curvatulus, Bacteriosira fragilis, Cyclotella striata, Delphineis kippae, N. seminae, Nitzschia cf. grunowii, $R$. hebetata f. hiemalis, Stephanopyxis dimorpha, Thalassiosira gravida with fine areolation, T. sancettae n. sp., and T. trifulta. Such low-latitude species as Coscinodiscus nodulifer, Planktoniella sol, Roperia tesselata, Pseudoeunotia doliolus, and T. lineata occur very sporadically. Displaced nonmarine diatoms are common in this interval, whereas they are practically absent in the underlying Pliocene and Miocene intervals. Reworked Pliocene and Miocene fossils are rather consistently present. The most common species among these reworked diatoms are Neodenticula kamtschatica, which attains relative frequencies of almost $10 \%$, and such species as A. ingens, Denticulopsis hustedtii s.l., and T. zabelinae, which occur less frequently. Percentages of resting spores of Chaetoceros and its allied forms are 
high in this interval, second only to their very abundant occurrence in the upper upper Miocene interval in this hole.

Two upper Pliocene diatom zones (the $N$. koizumii Zone [NPD9] and the underlying N. koizumii-N. kamtschatica Zone [NPD8]) are missing in this hole between $584-1-3,3-5 \mathrm{~cm}$ and $584-1-3,83-85 \mathrm{~cm}$. The lower Pliocene through the uppermost upper Miocene $N$. kamtschatica Zone (NPD7B) is recognized from 584-1-3, 83-85 cm through 584-51-3, 75-76 cm. The last occurrence of Rouxia californica, which marks the upper $b$ Subzone and the lower $a$ Subzone of Barron's (1980a) N. kamtschatica Zone, is between Samples 584-45,CC and 584-46,CC. It is generally regarded to approximate the Miocene/Pliocene boundary (Harper, 1977a; Barron, 1980a) and is coincident with both the last occurrence of Ikebea tenuis (=Goniothecium tenue) and the first occurrence of Rossiella tatsunokuchiensis. The coincidence of three events has already been noted by Koizumi (1977) and Barron (1980a).

The $N$. kamtschatica Zone, as modified in this chapter, is characterized by abundant to mass occurrence of $N$. kamtschatica throughout its interval in this hole. Other significant events recognized in this zone include a limited and common occurrence of Delphineis simonsenii between 584-14,CC and 584-34,CC; the first occurrence of Melosira albicans at 584-39,CC; the first occurrence of Nitzschia jouseae at 584-32,CC; the last common occurrence of $N$. rolandii Schrader emend. Koizumi at 584-41,CC; and the first occurrence of Thalassiosira jouseae n. sp. at 584-34,CC.

The interval from 584-51-4, 31-33 cm through 584$61-2,32-34 \mathrm{~cm}$ is assigned to the upper upper Miocene Rouxia californica Zone (NPD7A), of which the top is marked by the last common occurrence of $R$. californi$c a$. Common occurrences of $R$. californica and common to rare occurrences of Neodenticula kamtschatica characterize this zone. The relative frequency of $N$. kamtschatica decreases rapidly downhole near the base of the overlying $N$. kamtschatica Zone and is consistently low in the $R$. californica Zone. $N$. kamtschatica, recognized in the lower part of this zone, is represented generally by smaller specimens with narrower pseudosepta than those in the N. kamtschatica Zone, a morphologic characteristic that makes it difficult to clearly differentiate $N$. kamtschatica from Nitzschia rolandii. A short acme of Coscinodiscus sp. A, in 58452, CC and 584-53,CC near the top of this zone, also occurs in Hole 438A and has also been noticed in several sequences, both on-land and off-shore (on the Pacific Ocean side of Hokkaido). The brevity and the top of the range of this species are very useful in making an approximation of the top of the $R$. californica Zone (Akiba, 1982a, unpublished data). Odontella aurita also exhibits a short acme near the boundary between the Neodenticula kamtschatica Zone and the $R$. californica Zone (584-47,CC through 584$51, C C)$. This species is a long-ranging neritic species, but its acme may possibly have significant paleoceanologic meaning; this bloom occurs in many on-land sequences of Hokkaido (Akiba, unpublished data) as well as in Hole 438A. Nitzschia pliocena last occurs at Sam- ple $584-54, C C$. Other events recognized in the $R$. californica Zone include the last occurrence of Thalassiosira singularis at the top of this zone (Sample 584-51-4, $31-33 \mathrm{~cm}$ ); the last (common?) occurrence of Thalassiosira temperei in 584-54,CC: and an isolated occurrence of Asterolampra acutiloba at 584-56,CC.

The upper upper Miocene Thalassionema schraderi Zone (NPD6B) is recognized in the interval from 584$61, C C$ through $584-63-2,123-124 \mathrm{~cm}$. The top of this zone is marked by the last consistent occurrence of $T$. schraderi, but $T$. schraderi might be reworked uphole in Hole 584; it occurs rarely and sporadically in the overlying $R$. californica Zone. The first occurrence of Nitzschia pliocena is at 584-62,CC, and N. rolandii first occurs in Sample 584-63-1, 62-63 cm, although it only becomes common higher in the stratigraphic section, at 584-61, CC. An isolated occurrence of a low-latitude species, Thalassiosira burckliana, is recognized in Sample 584-63-2, 123-124 cm.

One of the most interesting and noteworthy features manifest in this zone and continuing through to the lower part of the overlying $R$. californica Zone is the abundant to mass occurrences of resting spores of Chaetoceros and its allied forms. In other intervals of this hole (with the exception of the thin Pleistocene section and a few other intervals), such resting spores occur on the order of less than 100 specimens per routine 100 count of diatom valves. The interval from 584-56, CC through 584-63-2, 123-124 cm, however, consistently yields an extreme abundance of such resting spores, more than 100 specimens and up to nearly 500 specimens in some cases when counted by the above-described method. Similarly, abundant and limited occurrences of these resting spores are also recognized in Hole 438 A and several on-land sequences of Hokkaido (Akiba and Ichinoseki, 1983). These occurrences and their possible implications will be discussed in more detail in a following section. It is worthwhile to note here, however, that intervals of very abundant occurrences of Coscinodiscus marginatus and also common occurrences of Synedra jouseana coincide with the mass occurrence of resting spores in Hole 584.

Three samples from 584-63,CC through Sample 58464,CC are assigned to the Denticulopsis katayamae Zone (NPD6A), the top of which is marked by the last common occurrence of $D$. hustedtii s.l. This zone is characterized by abundant to common occurrences of $D$. hustedtii s.l. above the last occurrence of $D$. dimorpha. In this zone $D$. hustedtii s.l. consists mainly of $D$. katayamae, as revealed by examination at higher magnification, although occurrences of the latter species are not tabulated here. The common occurrence of Thalassiosi$r a$ cf. praeconvexa is another characteristic feature of this zone at Site 584 .

The interval from 584-65-1, 138-139 cm through 584$74, C C$ belongs to the lower upper Miocene $D$. dimorpha Zone (NPD5D), based on the limited occurrence of $D$. dimorpha. Common to abundant occurrences of both $D$. dimorpha and $D$. hustedtii s.l. characterize this zone. The first occurrence of $D$. katayamae, included here with $D$. hustedtii s.l., is in the middle of this zone, as 
Table 2. Stratigraphic occurrence of diatoms in Holes 583, 583A, 583B, and 583C.

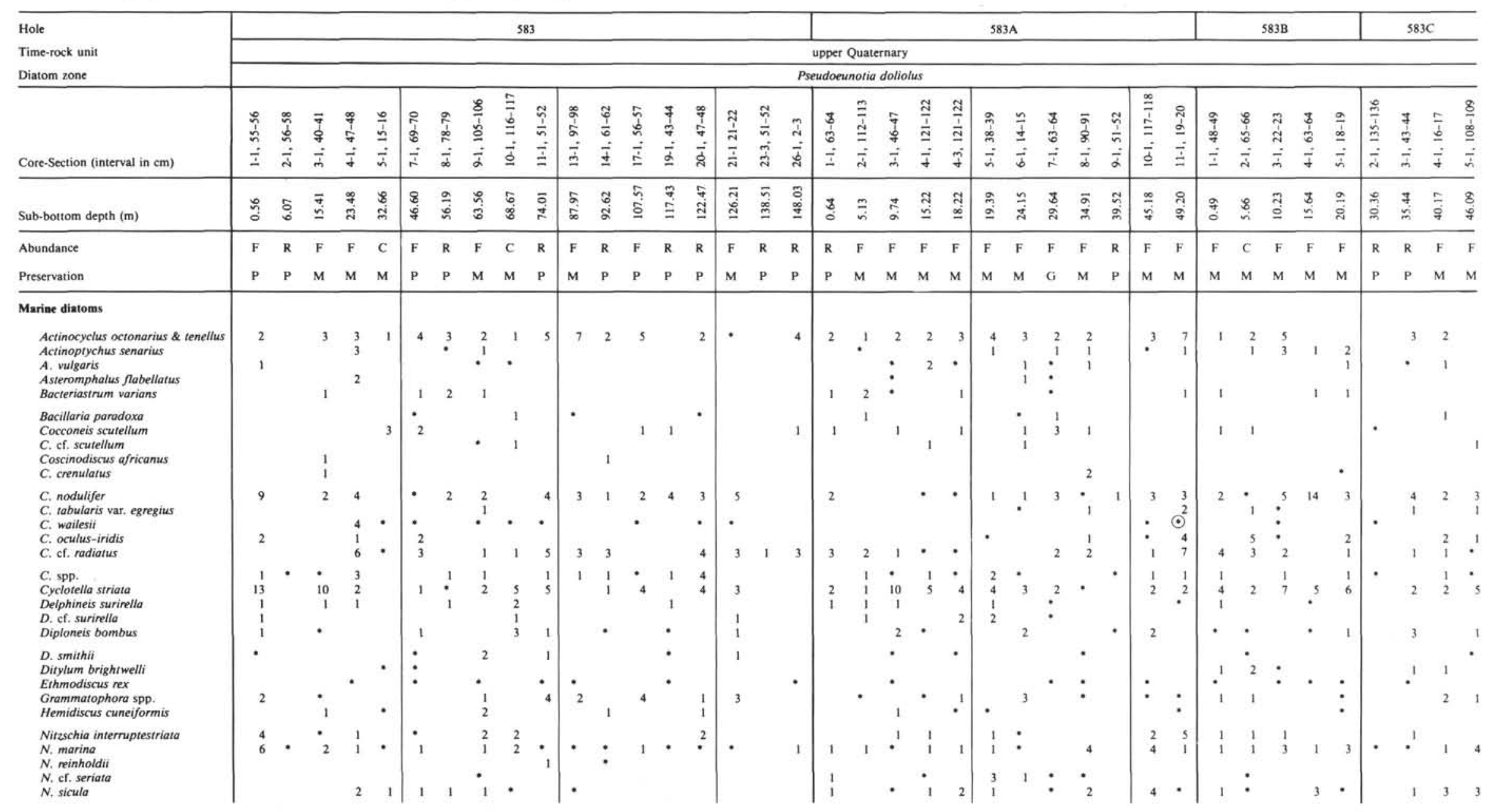




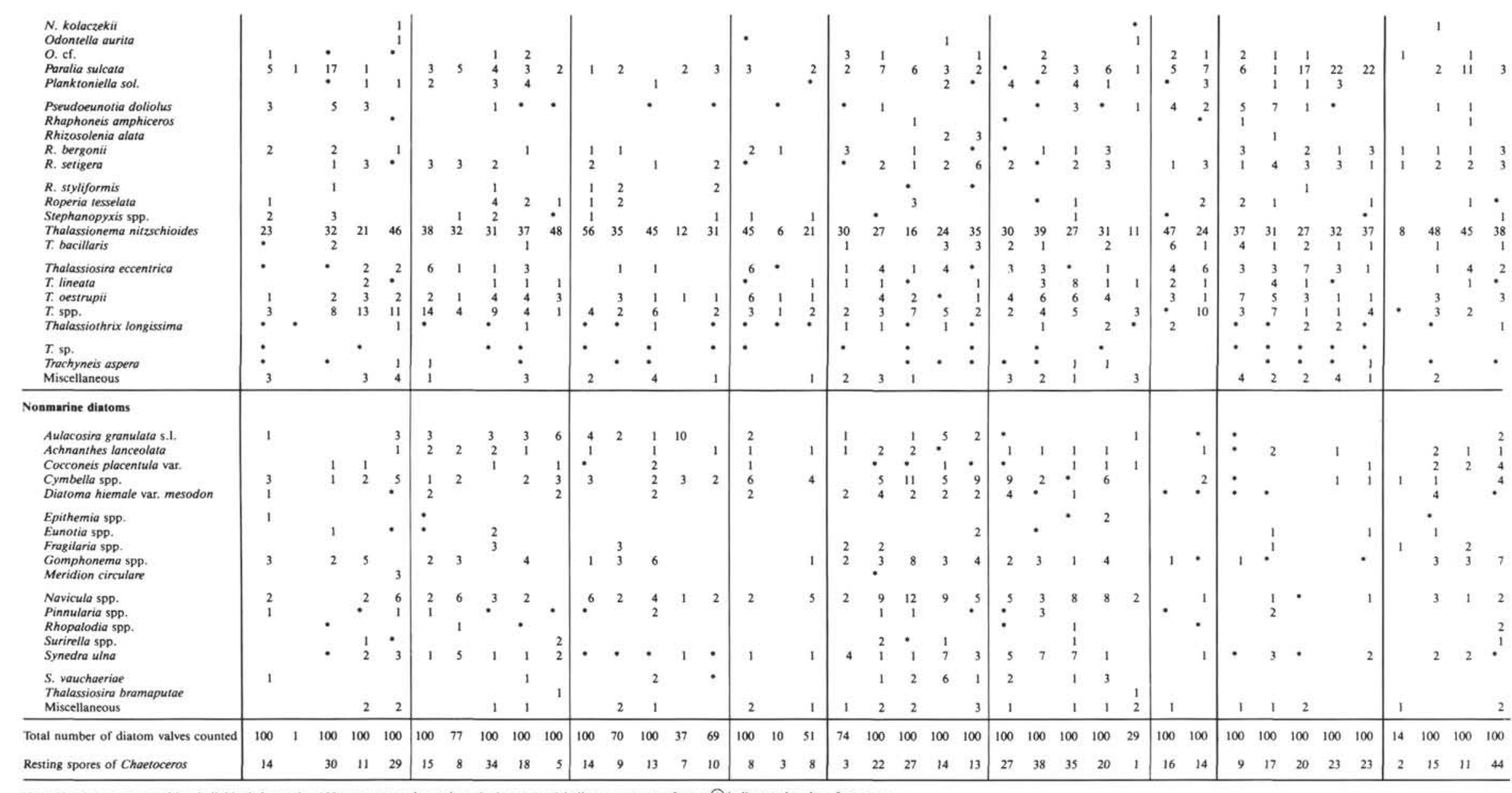

Note: Numbers represent either individuals in routine 100 count or total ones in a single mount; ${ }^{*}$ indicates presence of taxa; $\odot$ indicates abundant fragments. 
Table 3. Stratigraphic occurrence of diatoms in Holes 583D, 583F, and 583G.

\begin{tabular}{|c|c|c|c|c|c|c|c|c|c|c|c|c|c|c|c|c|c|c|c|}
\hline \multirow{4}{*}{$\begin{array}{l}\text { Hole } \\
\text { Time-rock unit } \\
\text { Diatom zone } \\
\end{array}$} & \multicolumn{19}{|c|}{ 583D } \\
\hline & \multicolumn{19}{|c|}{ upper Quaternary } \\
\hline & \multicolumn{19}{|c|}{ Pseudoeunotia doliolus } \\
\hline & & $\begin{array}{l}\text { aे } \\
\text { ले } \\
\vdots\end{array}$ & $\frac{a}{\frac{a}{5}}$ & 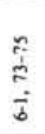 & $\begin{array}{l}\hat{i} \\
\frac{\hat{n}}{i}\end{array}$ & $\begin{array}{l}\frac{n}{2} \\
\frac{\dot{\infty}}{\infty}\end{array}$ & $\begin{array}{l}8 \\
\dot{1} \\
\infty \\
\dot{\alpha} \\
\bar{\alpha}\end{array}$ & $\frac{\approx}{\frac{n}{m}}$ & $\begin{array}{l}\tilde{n} \\
\tilde{n} \\
\vdots \\
\vdots\end{array}$ & $\begin{array}{l}\infty \\
\vdots \\
\infty \\
\dot{\Xi} \\
\underline{-}\end{array}$ & 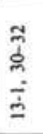 & 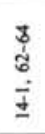 & 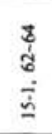 & 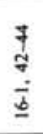 & 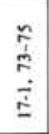 & $\begin{array}{l}\cong \\
\triangleq \underline{n} \\
\dot{a} \\
\dot{a}\end{array}$ & $\begin{array}{l}\frac{\bar{z}}{2} \\
\dot{\vec{d}}\end{array}$ & $\begin{array}{l}7 \\
\vdots \\
\vdots \\
\vdots \\
\vdots \\
\vdots\end{array}$ & $\begin{array}{l}\text { ڤే } \\
\tilde{n} \\
\dot{\sim}\end{array}$ \\
\hline Sub-bottom depth (m) & $\tilde{\pi}$ & 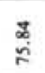 & $\underset{\infty}{\infty}$ & $\underset{c}{\vec{c}}$ & $\begin{array}{l}8 \\
\stackrel{0}{0}\end{array}$ & $\stackrel{8}{\square}$ & פ্ & $\underset{\Xi}{\approx}$ & 青 & $\overrightarrow{\dot{\omega}}$ & $\begin{array}{l}\vec{b} \\
\text { d }\end{array}$ & $\stackrel{\Xi}{\stackrel{0}{ \pm}}$ & $\underset{\infty}{\tilde{\infty}}$ & $\stackrel{\infty}{a}$ & 苂 & $\frac{\text { สె }}{\pi}$ & 离 & $\frac{0}{0}$ & $\underset{\substack{a \\
\infty}}{\stackrel{a}{\omega}}$ \\
\hline Abundance & $\mathrm{F}$ & $\mathrm{R}$ & $\mathrm{F}$ & R & $\mathrm{F}$ & F & F & $\mathbf{F}$ & F & $\mathbf{F}$ & F & R & R & $\mathrm{R}$ & R & $\mathrm{F}$ & R & R & $\mathbf{R}$ \\
\hline Preservation & M & $\mathbf{P}$ & P & $\mathbf{P}$ & $\mathbf{P}$ & M & P & $\mathbf{p}$ & M & P & $\mathbf{P}$ & P & $\mathbf{P}$ & $\mathbf{P}$ & P & P & $\mathbf{P}$ & P & $\mathbf{P}$ \\
\hline \multicolumn{20}{|l|}{ Marine diatoms } \\
\hline $\begin{array}{l}\text { A. octonarius \& tenellus } \\
\text { Actinoptychus senarius } \\
\text { Asteromphalus flabellatus } \\
\text { Bacteriastrum varians } \\
\text { Bacillaria paradoxa }\end{array}$ & $\begin{array}{l}5 \\
3\end{array}$ & & $\begin{array}{l}1 \\
2 \\
1\end{array}$ & & & $\begin{array}{l}7 \\
1\end{array}$ & $\begin{array}{l}6 \\
1\end{array}$ & 4 & $\begin{array}{l}4 \\
1\end{array}$ & 5 & 1 & 4 & 1 & & 3 & 4 & 2 & 1 & \\
\hline $\begin{array}{l}\text { Cocconeis scutellum } \\
\text { C. cf. scutellum } \\
\text { Coscinodiscus nodulifer } \\
\text { C. tabularis var. egregius } \\
\text { C. wailesii }\end{array}$ & $\begin{array}{r}13 \\
1\end{array}$ & - & 3 & - & 3 & $\stackrel{12}{\odot}$ & $\begin{array}{l}1 \\
7 \\
1\end{array}$ & $\begin{array}{l}2 \\
1 \\
.\end{array}$ & $\begin{array}{l}9 \\
.\end{array}$ & $\begin{array}{l}8 \\
.\end{array}$ & 1 & $\begin{array}{l}1 \\
2 \\
\cdot\end{array}$ & $\begin{array}{l}1 \\
\cdot\end{array}$ & 1 & $\begin{array}{l}1 \\
2\end{array}$ & $\begin{array}{l}3 \\
1\end{array}$ & $\odot$ & $\begin{array}{l}1 \\
!\end{array}$ & . \\
\hline $\begin{array}{l}\text { C. oculus-iridis } \\
\text { C. cf. radiatus } \\
\text { C. spp. } \\
\text { Cyclotella striata } \\
\text { Delphineis surirella }\end{array}$ & $\begin{array}{c}4 \\
9 \\
10 \\
1\end{array}$ & • & $\begin{array}{l}3 \\
5 \\
1\end{array}$ & $\dot{3}$ & ; & 3 & $\begin{array}{l}8 \\
8 \\
1 \\
5\end{array}$ & 7 & $\begin{array}{l}2 \\
1 \\
2\end{array}$ & $\begin{array}{l}3 \\
4 \\
4 \\
4\end{array}$ & 3 & $\begin{array}{l}1 \\
4 \\
3\end{array}$ & $\begin{array}{l}1 \\
4 \\
1 \\
.\end{array}$ &. & $\dot{1}$ &.$_{8}^{1}$ & $\dot{2}$ & $\begin{array}{l}2 \\
3 \\
2\end{array}$ & $\stackrel{1}{\cdot}$ \\
\hline $\begin{array}{l}\text { D. cf. surirella } \\
\text { Diploneis bombus } \\
\text { D. smithii } \\
\text { D. spp. } \\
\text { Ethmodiscus rex }\end{array}$ & $\begin{array}{l}1 \\
.\end{array}$ & & $\cdot$ & 1 & • & 2 & : & & • & - & 1 & $\begin{array}{l}1 \\
1\end{array}$ & • & & : & $\cdot$. & & & \\
\hline $\begin{array}{l}\text { Grammatophora spp. } \\
\text { Hemidiscrus cuneiformis } \\
\text { Nitzschia interruptestriata }\end{array}$ & $\dot{1}$ & & 3 & - & 2 & 4 &.$^{5}$ & $\begin{array}{l}3 \\
1\end{array}$ & 3 & & & 4 & & & 1 & 4 & & 1 & 1 \\
\hline $\begin{array}{l}\text { N. marina } \\
\text { N. reinholdii }\end{array}$ & 3 & - & 2 & - & - & - & 1 & 2 & 1 & 1 & 1 & $\begin{array}{l}1 \\
1\end{array}$ & - & & - & 2 & & - & - \\
\hline $\begin{array}{l}\text { N. sp. (skeleton) } \\
\text { Paralia sulcata } \\
\text { Planktoniella sol } \\
\text { Pseudoeunotia doliolus } \\
\text { Rhizosolenia alata }\end{array}$ & $\begin{array}{l}4 \\
1 \\
2\end{array}$ & 4 & $\begin{array}{l}\cdot \\
4 \\
1 \\
1\end{array}$ & $\begin{array}{l}5 \\
1\end{array}$ & 22 & $\begin{array}{l}13 \\
. \\
.\end{array}$ & $\begin{array}{l}12 \\
1\end{array}$ & 1 & 2 & $\begin{array}{l}3 \\
2\end{array}$ & 1 & 1 & $\dot{4}$ & & 3 & $\begin{array}{l}25 \\
\text {. }\end{array}$ & i & $\begin{array}{l}5 \\
1 \\
.\end{array}$ & 2 \\
\hline $\begin{array}{l}\text { R. bergonii } \\
\text { R. calcaravis } \\
\text { R. setigera } \\
\text { R. styliformis } \\
\text { Stephanopyxis spp. }\end{array}$ & $\begin{array}{l}1 \\
1 \\
1\end{array}$ & 1 & 2 & 2 & 2 & $\begin{array}{l}1 \\
1 \\
2\end{array}$ & 2 & 4 & 6 & 2 & $\begin{array}{l}2 \\
1 \\
3\end{array}$ & 1 & 2 & & $\begin{array}{l}2 \\
1 \\
3\end{array}$ & $\begin{array}{l}2 \\
1 \\
\cdot\end{array}$ & 1 & & \\
\hline $\begin{array}{l}\text { Thalassionema nitzschioides } \\
\text { T. bacillaris } \\
\text { Thalassiosira eccentrica } \\
\text { T. lineata } \\
\text { T. oestrupii }\end{array}$ & $\begin{array}{r}21 \\
3 \\
1 \\
3\end{array}$ & $\begin{array}{l}6 \\
. \\
1\end{array}$ & 46 & $\begin{array}{l}9 \\
1\end{array}$ & $\begin{array}{r}41 \\
2\end{array}$ & 30 & $\begin{array}{c}17 \\
1\end{array}$ & $\begin{array}{r}47 \\
1 \\
1\end{array}$ & ss & 56 & $\begin{array}{r}68 \\
\cdot \\
\cdot \\
1\end{array}$ & $\begin{array}{r}33 \\
2 \\
2\end{array}$ & 6 & ? & $\begin{array}{r}22 \\
1 \\
1 \\
1\end{array}$ & $\begin{array}{r}23 \\
2\end{array}$ & $\begin{array}{l}8 \\
1\end{array}$ & 36 & $\begin{array}{l}2 \\
1\end{array}$ \\
\hline $\begin{array}{l}\text { T. spp. } \\
\text { Thalassiothrix longissima } \\
\text { T. sp. } \\
\text { Trachyneis aspera } \\
\text { Miscellaneous }\end{array}$ & $\vdots_{2}^{2}$ & ! & $\dot{0}^{5}$ & - & 2 &.$^{2}$ & $\begin{array}{c}\cdot^{4} \\
1\end{array}$ & $\begin{array}{l}2 \\
\cdot \\
+ \\
2\end{array}$ & 3 & $:^{3}$ &.$^{2}$ & ${ }_{1}^{3}$ & $\cdot$ & - & .4 & $\begin{array}{l}5 \\
\dot{1}\end{array}$ &. & ? & $:^{2}$ \\
\hline \multicolumn{20}{|l|}{ Nonmarine diatoms } \\
\hline $\begin{array}{l}\text { Aulacosira granulate s.1. } \\
\text { Achnanthes lanceolata } \\
\text { Cocconeis placentula var. } \\
\text { Cyclotella comta } \\
\text { Cymbella sinuata }\end{array}$ & & 1 & 1 & 1 & & $\frac{1}{2}$ & $\begin{array}{l}9 \\
1 \\
2 \\
1 \\
1\end{array}$ & 1 & $\cdot$ & $i_{1}^{2}$ & 2 & 1 & & 3 & $\begin{array}{l}3 \\
2 \\
1 \\
.\end{array}$ & $\begin{array}{l}2 \\
2 \\
3\end{array}$ & 1 & 1 & 1 \\
\hline $\begin{array}{l}\text { C. spp. } \\
\text { Diotoma hiemalis var. mesodon } \\
\text { Epithemia spp. } \\
\text { Eunotia spp. } \\
\text { Fragilaria spp. }\end{array}$ & 3 & & 2 & & $\begin{array}{l}2 \\
3 \\
1\end{array}$ &.$^{1}$ & $\begin{array}{l}2 \\
2 \\
\dot{3}\end{array}$ & 1 & $\cdot$ & 1 & $\begin{array}{l}1 \\
1\end{array}$ & & i & & $\begin{array}{l}3 \\
2 \\
2\end{array}$ & 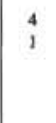 & 1 & 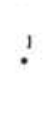 & 1 \\
\hline $\begin{array}{l}\text { Gomphonema spp. } \\
\text { Navicula spp. } \\
\text { Pinnularia spp. } \\
\text { Rhopalodia spp. } \\
\text { Surirella spp. }\end{array}$ & 1 & & 2 & 1 & $\frac{1}{2}$ & 1 & $\stackrel{1}{1}$ & $\begin{array}{l}2 \\
4 \\
1\end{array}$ & . & $\frac{1}{2}$ & $\begin{array}{l}3 \\
1 \\
1\end{array}$ & $\begin{array}{l}1 \\
2\end{array}$ & & & $\begin{array}{l}1 \\
.\end{array}$ & 1 & & 1 &. \\
\hline $\begin{array}{l}\text { Synedra uina } \\
S \text { vauchaeriae } \\
\text { Miscellaneous }\end{array}$ & $\cdot$ & $\cdot$ & $\begin{array}{l}5 \\
1 \\
1\end{array}$ & & • & $\cdot$ & 3 & 2 & $i$ & - & 1 & 2 & - & & 1 & $\cdot$ & $i$ & & 1 \\
\hline Total number of diatom valves counted & 100 & 14 & 100 & 24 & 100 & 100 & 100 & 100 & 100 & 100 & 100 & 78 & 30 & 16 & $\infty$ & 100 & 23 & 62 & 23 \\
\hline Resting spores of Chaetoceros & 3 & 5 & 28 & 2 & 27 & 19 & 7 & 15 & 13 & 19 & 7 & 5 & 3 & & 20 & 24 & 1 & 3 & 4 \\
\hline
\end{tabular}

Note: Numbers represent either individuals in routine 100 count or total ones in a single mount; ${ }^{*}$ indicates presence of taxa; $\odot^{\circ}$ indicates abundant fragments. 
Table 3. (Continued).

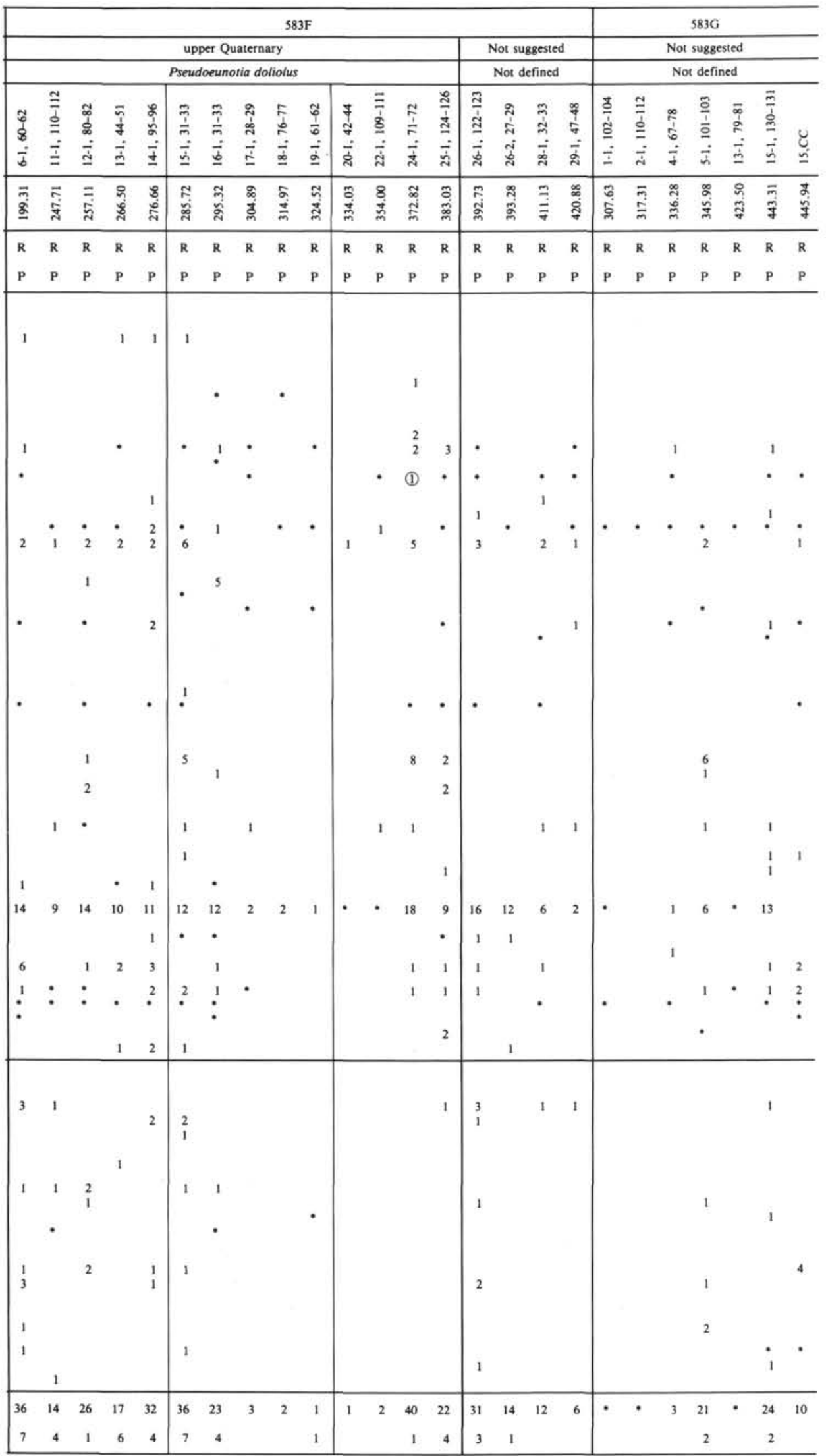


Table 4. Summary of diatom zonations in this chapter, except those of the Nankai Trough.

\begin{tabular}{|c|c|c|c|c|c|c|c|c|c|}
\hline \multicolumn{2}{|r|}{ Diatom zone } & \multicolumn{3}{|c|}{ Leg 87} & \multicolumn{3}{|c|}{ Leg 57} & \multicolumn{2}{|c|}{ Leg 19} \\
\hline NPD & Name & 584 & $584 \mathrm{~A}$ & 584B & $438 \mathrm{~A}^{\mathrm{a}}$ & $438 \mathrm{~B}^{\mathrm{b}}$ & 439 & 183 & 192 \\
\hline 12 & Neodenticula seminae & $\begin{array}{l}1-1,0-3 \\
1-1,83-85\end{array}$ & $\begin{array}{l}\mathrm{H} 1-1,100-101 \\
\mathrm{H} 1-6,100-101\end{array}$ & $1, \mathrm{CC}$ & $\begin{array}{l}1-2 \\
2-1\end{array}$ & & & & \\
\hline 11 & Rhizosolenia curvirostris & $1-2,83-85$ & H1-6, 121-123 & & $3-3$ & & & & \\
\hline 10 & Actinocyclus oculatus & $1-3,3-5$ & & & $4-4$ & & & & \\
\hline 9 & Neodenticula koizumii & & & & $5-4$ & & & & \\
\hline 8 & N. koizumii-N. kamtschatica & & & & & & & & \\
\hline $7 \mathrm{~B}$ & Neodenticula kamtschatica & $\begin{array}{l}1-3,83-85 \\
51-3,75-76\end{array}$ & & $\begin{array}{l}\mathrm{H} 1-1,38-40 \\
\mathrm{H} 1, \mathrm{CC}\end{array}$ & $\begin{array}{l}6-1 \\
41, \mathrm{CC}\end{array}$ & & & $\begin{array}{l}17-1 \\
17, \mathrm{CC}\end{array}$ & $\begin{array}{l}21-1 \\
21, \mathrm{CC}\end{array}$ \\
\hline $7 \mathrm{~A}$ & Rouxia californica & $\begin{array}{l}51-4,31-33 \\
61-2,32-34\end{array}$ & & $\begin{array}{l}\mathrm{H} 2, \mathrm{CC} \\
2, \mathrm{CC}\end{array}$ & $\begin{array}{l}42-1 \\
42, \mathrm{CC}\end{array}$ & & & $18-2$ & $\begin{array}{l}22-1 \\
23, \mathrm{CC}\end{array}$ \\
\hline $6 \mathrm{~B}$ & Thalassionema schraderi & $\begin{array}{l}61, C C \\
63-2,123-124\end{array}$ & & & $\begin{array}{l}43, \mathrm{CC} \\
50-7\end{array}$ & & & $\begin{array}{l}18-3 \\
18, \mathrm{CC}\end{array}$ & $24-2$ \\
\hline $6 \mathrm{~A}$ & Denticulopsis katayamae & $\begin{array}{l}63, \mathrm{CC} \\
64, \mathrm{CC}\end{array}$ & & $\mathrm{H} 3, \mathrm{CC}$ & $\begin{array}{l}51-7 \\
55-6\end{array}$ & & & & $\begin{array}{l}24, \mathrm{CC} \\
25-1\end{array}$ \\
\hline $5 \mathrm{D}$ & Denticulopsis dimorpha & $\begin{array}{l}65-1,138-139 \\
74, C C\end{array}$ & $\begin{array}{l}1, \mathrm{CC} \\
\mathrm{H} 2, \mathrm{CC}\end{array}$ & & $\begin{array}{l}56, \mathrm{CC} \\
59-5\end{array}$ & & & $\begin{array}{l}19-2 \\
19, \mathrm{CC}\end{array}$ & $25, \mathrm{CC}$ \\
\hline $5 \mathrm{C}$ & Thalassiosira yabei & $\begin{array}{l}75, \mathrm{CC} \\
82, \mathrm{CC}\end{array}$ & $2, \mathrm{CC}$ & $\mathrm{H} 4, \mathrm{CC}$ & $\begin{array}{l}60-3 \\
63-1\end{array}$ & & & & $\begin{array}{l}26-1 \\
26, C C\end{array}$ \\
\hline $5 \mathrm{~B}$ & Denticulopsis praedimorpha & $\begin{array}{l}83-1,139-140 \\
91, C C\end{array}$ & $\mathrm{H} 3, \mathrm{CC}$ & & $\begin{array}{l}64-7 \\
66-2,34-36\end{array}$ & & & & \\
\hline $5 \mathrm{~A}$ & Crucidenticula nicobarica & & & & $66-2,82-84$ & & & & \\
\hline 4B & Denticulopsis hyalina & $\begin{array}{l}92, \mathrm{CC} \\
93, \mathrm{CC}\end{array}$ & $\begin{array}{l}3, \mathrm{CC} \\
\mathrm{H} 4, \mathrm{CC}\end{array}$ & & $\begin{array}{l}67-1 \\
72-1\end{array}$ & & & $20, \mathrm{CC}$ & \\
\hline $4 \mathrm{~A}$ & Denticulopsis lauta & $\begin{array}{l}94-1,69-70 \\
98, \mathrm{CC}\end{array}$ & $\mathrm{X} 1, \mathrm{CC}$ & $3, \mathrm{CC}$ & $\begin{array}{l}72-3 \\
82-1\end{array}$ & & $5-1$ & & \\
\hline 3B & Denticulopsis praelauta & & & & $\begin{array}{l}84-3 \\
85-1\end{array}$ & $\begin{array}{l}6-1 \\
8-1\end{array}$ & $\begin{array}{l}7-4 \\
10-4\end{array}$ & & \\
\hline $3 \mathrm{~A}$ & Crucidenticula kanayae & & & & & $\begin{array}{l}10-1 \\
16-1\end{array}$ & $11-4$ & & \\
\hline 2 & Thalassiosira fraga & & & & & & $\begin{array}{l}17-2 \\
20-3\end{array}$ & & \\
\hline
\end{tabular}

Note: Location expressed as core-section or core-section (interval in $\mathrm{cm}$ ).

a Barron, 1980a; Akiba et al., 1982; Maruyama, 1984.

b Barron, 1980a; Akiba et al., 1982.

suggested by correlation with Hole 438A. No other significant events are recognized, partly because of poor and very poor preservation of diatoms in this and in the underlying zones, and partly because of very low specific diversities.

Samples 584-75,CC through 584-82,CC are assigned to the lower upper Miocene Thalassiosira yabei Zone (NPD5C), the top of which is a horizon just below the first occurrence of $D$. dimorpha. The boundary between the upper Miocene and middle Miocene lies near the base of this zone, as suggested by the paleomagnetic calibration and Barron (1980a). T. yabei is rare but consistent in this zone, although it also occurs sporadically in both the upper and lower sequences. Actinocyclus ingens occurs very abundantly starting from the top of this zone down to the bottom of this hole, which might suggest that dissolution of diatom remains is much stronger here than in the overlying interval.

The upper middle Miocene $D$. praedimorpha Zone (NPD5B) includes Samples 584-83-1, 139-140 cm through $584-91, \mathrm{CC}$ and is characterized by common to abun- dant, but limited, occurrences of $D$. praedimorpha and common occurrences of $D$. hustedtii. D. praedimorpha, found in the lower part of this zone, especially in Samples 584-91-1, 70-71 cm and 584-91,CC, is consistently represented by specimens smaller than the typical specimen. These individuals may represent $D$. praedimorpha's evolutionally primitive forms. Nitzschia umaoiensis n. $\mathrm{sp}$. is almost confined to this zone, whereas its closely related species, $N$. heteropolica, occurs in younger horizons, with short overlapping ranges of the two species in the overlying $T$. yabei Zone. The first occurrence of Rhizosolenia barboi is in Sample 584-83-3, 139-140 cm. The recognition of this event is not definite at present, because some forms are intermediate between this species and its ancestral form, $R$. praebarboi. Crucidenticula punctata is rare and occurrences are virtually limited to this zone.

Between 584-91, CC and 584-92,CC, the middle middle Miocene $C$. nicobarica Zone (NPD5A) is missing, and 584-92,CC through 584-93,CC are assigned to the Denticulopsis hyalina Zone (NPD4B), the top of which 
is just below the first common occurrence of $D$. hustedtii in Sample 584-92,CC. This zone is characterized by a mass occurrence of $D$. hyalina at its upper part and by common to abundant occurrences of both $D$. hyalina and D. lauta at its lower part. The last common occurrence of $D$. lauta is in the middle of this zone. The species is practically missing in the overlying zones in this hole.

The lowermost diatom zone recognized in Hole 584 is the Denticulopsis lauta Zone (NPD4A), which spans the interval from 584-94-1, 67-70 cm through 584-98,CC $(931.9 \mathrm{~m})$. It is characterized by rare to common occurrences of $D$. lauta. The top of this zone is just below the first occurrence of D. hyalina in Sample 584-93, CC. Actinocyclus ingens dominates the diatom flora of this zone (about $40-80 \%$ ). Sporadic occurrences of $D$. praelauta n. sp., C. ikebei, and C. kanayae are limited to this interval. The middle Miocene/lower Miocene boundary is at the base of this zone (Barron, 1980a). Hole 584 reached, therefore, to a level very close to the lower Miocene.

\section{Hole 584A}

Hole 584 was abandoned because the drill pipe stuck near $900 \mathrm{~m}$ sub-bottom depth, where an intensely fractured shear zone might be present. Therefore, Hole 584A $\left(40^{\circ} 28.0^{\prime} \mathrm{N}, 143^{\circ} 57.6^{\prime} \mathrm{E}\right.$; water depth $\left.4094 \mathrm{~m}\right)$ was drilled to fulfill the initial objectives of the site. This hole was washed down to $602 \mathrm{~m}$ first, and by repeated washing, several wash and spot cores were recovered. The lowermost sediment recovered was again lower middle Miocene at $882 \mathrm{~m}$ sub-bottom depth.

Diatoms recognized from this hole are shown in Tables 5 and 8 . About $8 \mathrm{~m}$ of Quaternary sediment unconformably overlies a thin, lower Pliocene sequence in wash Core 584A-H1. Samples 584A-H1-1, 100-101 cm through 584A-H1-6, 100-101 cm are assigned to the Neodenticula seminae Zone (NPD12), and Sample 584A-H1-6, $121-123 \mathrm{~cm}$ belongs to the Rhizosolenia curvirostris Zone (NPD11). The Quaternary samples generally contain abundant resting spores and also several reworked species such as $N$. kamtschatica and Denticulopsis hustedtii s.l. The lower Pliocene $N$. kamtschatica Zone (NPD7B) is recognized in Samples 584A-H1-6, 130-131 cm and 584A-H1,CC. Three diatom zones, namely the Actinocyclus oculatus Zone (NPD10), the $N$. koizumii Zone (NPD9), and the N. koizumii-N. kamtschatica Zone (NPD8) are missing between Samples 584A-H1-6, 121$123 \mathrm{~cm}(8.72 \mathrm{~m}$ sub-bottom) and 584A-H1-6, 130-131 $\mathrm{cm}(8.81 \mathrm{~m})$.

Samples 584A-1,CC $(604.55 \mathrm{~m})$ and 584A-H2,CC $(614.98 \mathrm{~m})$ belong to the $D$. dimorpha Zone (NPD5D), which is characterized by common to abundant occurrences of both $D$. dimorpha and $D$. hustedtii s.l. Samples 584A-2,CC (703.62 m) and 584A-H3,CC (711.62 m) are assigned to the Thalassiosira yabei Zone (NPD5C) and the $D$. praedimorpha Zone (NPD5B), respectively. Assemblages from these two samples are dominated by $D$. hustedtii, but $D$. praedimorpha is found only in the latter sample. Samples 584A-3,CC (789.19 m) and 584A$\mathrm{H} 4, \mathrm{CC}(811.21 \mathrm{~m})$ belong to the $D$. hyalina Zone (NPD4B), assemblages dominated by $D$. hyalina. Sam- ple $584 \mathrm{~A}-\mathrm{X} 1, \mathrm{CC}(882.15 \mathrm{~m})$ is assigned to the D. lauta Zone (NPD4A) based on the presence of $D$. lauta and the absence of $D$. hyalina.

\section{Hole 584B}

Hole 584A was abandoned because the drill pipe again stuck, this time at $890 \mathrm{~m}$ sub-bottom depth, in sediment similar to the lowermost sediment recovered at Hole 584 . Therefore, Hole 584B $\left(40^{\circ} 28.0^{\prime} \mathrm{N}, 143^{\circ} 56.7^{\prime} \mathrm{E}\right.$; water depth $4086 \mathrm{~m}$ ) was drilled in an effort to recover older sediments not reached in previous holes. This hole, however, also terminated at the same horizon where the previous two holes had terminated.

Occurrences of selected diatoms from this hole are shown in Tables 5 and 8. All samples examined contain common to abundant diatom remains in varying states of preservation. Sample 584B-1,CC is assigned to the upper Quaternary Neodenticula seminae Zone (NPD12). This interval yields abundant resting spores of Chaetoceros, similar to the Quaternary sequences of the previous two holes. Samples 584B-H1-1, 39-40 cm (1.80 m sub-bottom) and 584B-H1, CC $(2.97 \mathrm{~m})$ are assigned to the $N$. kamtschatica Zone (NPD7B), and Samples 584B$\mathrm{H} 2, \mathrm{CC}(518.63 \mathrm{~m})$ and 584B-2, CC $(651.20 \mathrm{~m})$ belong to the Rouxia californica Zone (NPD7A). Resting spores of Chaetoceros are abundant in Sample 584B-2,CC. Samples 584B-H3,CC (658.12 m) and 584B-H4,CC (849.26 m) are assigned to the Denticulopsis katayamae (NPD6A) and Thalassiosira yabei zones (NPD5C), respectively. Denticulopsis hustedtii s.l. dominates assemblages of these latter two samples, but examination at higher magnifications reveals that occurrences of $D$. katayamae, included in D. hustedtii s.l. in the occurrence chart, are limited in 584B-H3,CC. The lowermost sample, 584B$3, \mathrm{CC}(946.20 \mathrm{~m})$, belongs to the $D$. lauta Zone (NPD4A), which is characterized by a rare but limited occurrence of D. lauta. Actinocyclus ingens dominates this assemblage, which indicates poor preservation.

Correlation of the three holes at Site 584 based on diatom and paleomagnetic evidence (Niitsuma, this volume) and measurements of dip angles of sediments show that upper Miocene and middle Miocene intervals of these holes consistently dip eastward with high angles (Fig. 4). The dip alone should account for several hundred meters of displacement of upper Miocene and middle Miocene intervals between Holes 584A and 584B, which are separated by a distance of more than $1 \mathrm{~km}$. Marker horizons, identifiable by diatom and paleomagnetic evidence, however, drop only very slightly eastward. Numerous eastward-dipping thrusts or westwarddipping normal faults must offset these three holes.

\section{Hole 438A}

Diatom biostratigraphy of Hole 438A of Leg $57\left(40^{\circ}\right.$ $37.79^{\prime} \mathrm{N}, 143^{\circ} 14.15^{\prime} \mathrm{E}$; water depth $1558 \mathrm{~m}$ ) was reported in great detail (Barron, 1980a). Located at about 70 $\mathrm{km}$ to the northeast and landward of Hole 584, the site is one of the best and most important Neogene diatomaceous reference sections available so far in the northwestern Pacific because (1) it includes the most complete and continuous diatom zones of the middle-to-high 
Table 5. Stratigraphic occurrences of diatoms in Holes 584, 584A, and 584B (upper Quaternary intervals).

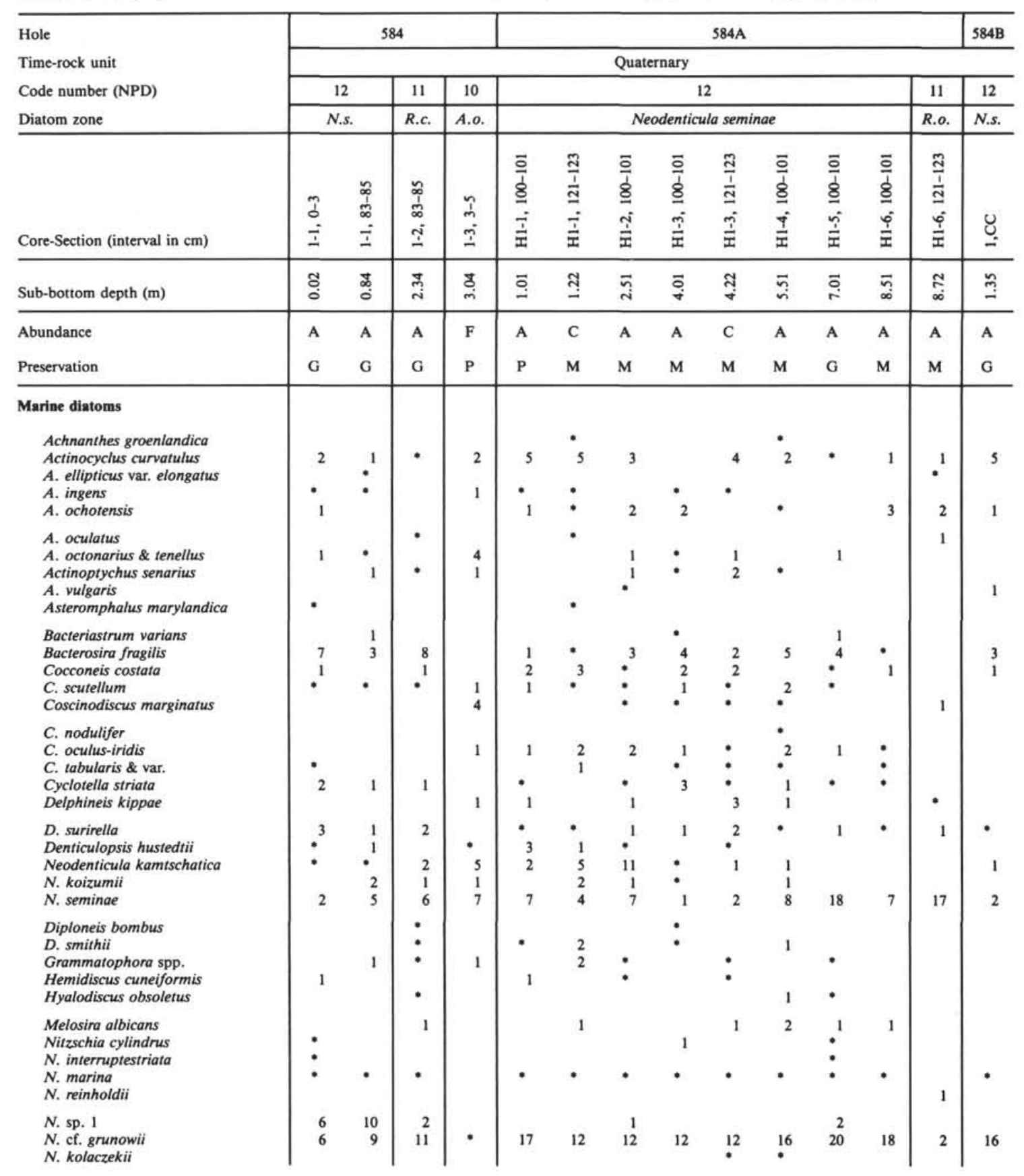




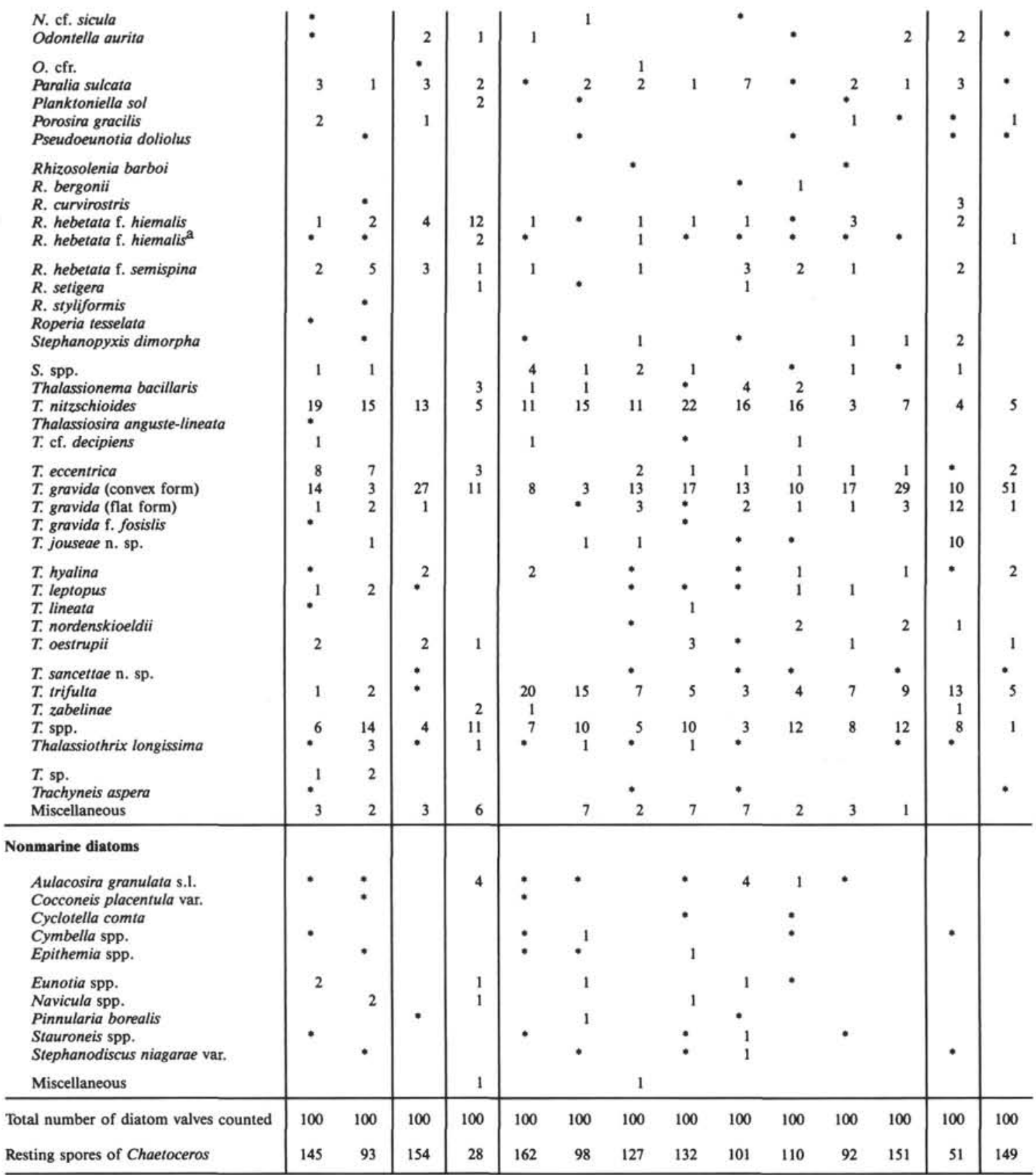

Note: Numbers represent individuals in routine 100 count; $\bullet$ indicates presence of taxa. 
Table 6. Stratigraphic occurrence of diatoms in Hole 584 (Pliocene through upper Miocene intervals).

\begin{tabular}{|c|c|c|c|c|c|c|c|c|c|c|c|c|c|c|c|c|c|c|c|c|c|c|c|c|}
\hline \multirow{3}{*}{$\begin{array}{l}\text { Time-rock unit } \\
\text { Code number (NPD) } \\
\text { Diatom zone }\end{array}$} & \multicolumn{24}{|c|}{ lower Pliocene } \\
\hline & \multicolumn{24}{|c|}{$7 \mathrm{~B}$} \\
\hline & \multicolumn{24}{|c|}{ Neodenticula kamtschatica } \\
\hline Core-Section (interval in $\mathrm{cm}$ ) & $\begin{array}{l}\infty \\
\infty \\
\infty \\
\infty \\
\dot{2} \\
-\end{array}$ & $\underline{U}$ & $\underset{i}{\stackrel{i}{u}}$ & $\underset{j}{\stackrel{u}{u}}$ & 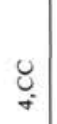 & $\underset{\sim}{u}$ & $\underset{\dot{U}}{\mathcal{U}}$ & $\underset{\sim}{\stackrel{U}{*}}$ & $\underset{\infty}{\stackrel{\infty}{0}}$ & $\underset{U}{U}$ & $\begin{array}{l}\text { U. } \\
\stackrel{0}{0}\end{array}$ & $\begin{array}{l}\mathcal{U} \\
=\end{array}$ & $\begin{array}{l}\underset{U}{U} \\
\mathbb{Z}\end{array}$ & $\begin{array}{l}\dot{U} \\
\stackrel{\sim}{-}\end{array}$ & $\begin{array}{l}U \\
\dot{I} \\
\pm\end{array}$ & $\begin{array}{l}\ddot{u} \\
\underline{\underline{u}}\end{array}$ & $\begin{array}{l}\dot{U} \\
\underline{0}\end{array}$ & 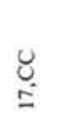 & $\begin{array}{l}\underset{U}{u} \\
\propto\end{array}$ & 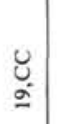 & 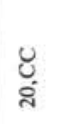 & 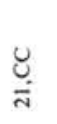 & 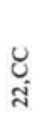 & $\begin{array}{l}\text { U. } \\
\text { i }\end{array}$ \\
\hline Sub-bottom depth (m) & 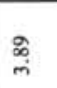 & $\approx$ & $\begin{array}{l}\stackrel{8}{0} \\
\underline{\mathbf{n}}\end{array}$ & $\begin{array}{l}\tilde{\alpha} \\
\check{\lambda}\end{array}$ & $\begin{array}{l}\alpha \\
\infty \\
\infty\end{array}$ & $\underset{\substack{\vec{j} \\
\dot{w}}}{\bar{j}}$ & $\frac{\bar{n}}{\bar{n}}$ & $\frac{m}{8}$ & సิ & 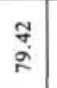 & $\frac{a}{a}$ & 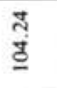 & 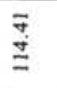 & $\begin{array}{l}\stackrel{\circ}{ \pm} \\
\stackrel{\Xi}{\beth}\end{array}$ & 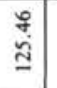 & $\begin{array}{l}\text { 定 } \\
\text { 严 }\end{array}$ & 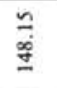 & $\begin{array}{l}\tilde{b} \\
\underline{\vdots}\end{array}$ & $\begin{array}{l}\bar{u} \\
\underline{i}\end{array}$ & $\begin{array}{l}\vec{b} \\
\stackrel{\infty}{\infty} \\
-\end{array}$ & $\begin{array}{l}\text { สิ } \\
\Xi\end{array}$ & 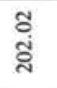 & 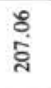 & $\begin{array}{l}\text { สั } \\
\text { สุ่ }\end{array}$ \\
\hline Abundance & A & A & A & A & A & A & A & A & A & A & A & A & A & A & $\mathrm{A}$ & A & A & A & A & A & A & A & A & c \\
\hline Preservation & G & G & M & G & G & G & G & G & G & $\mathrm{M}$ & G & G & G & G & G & G & $\mathrm{M}$ & G & G & G & G & G & M & M \\
\hline Marine diatoms & & & & & & & & & & & & & & & & & & & & & & & & \\
\hline $\begin{array}{l}\text { Actinocyclus curvatulus } \\
\text { A. ellipticus } \\
\text { A. ellipticus var. elongatus } \\
\text { A. ingens } \\
\text { A. ochotensis }\end{array}$ & 1 & - & 1 & 1 & • & & • & & $\cdot$ & - & $\cdot$ & • & • & & 1 & • & & & & $\cdot$ & & $\dot{.}$ & $\cdot$ & $*^{1}$ \\
\hline $\begin{array}{l}\text { A. octonarius \& tenellus } \\
\text { Actinoptycus senarius } \\
\text { Asterolampra acutiloba } \\
\text { Asteromphalus spp. } \\
\text { Bacterosira fragilis }\end{array}$ & ${ }^{*}$ & 7 & 5 & 2 & : & 2 & $\begin{array}{l}1 \\
.\end{array}$ & 6 & $\dot{ }^{2}$ & $\begin{array}{l}6 \\
2\end{array}$ & $\dot{1}$ & $\cdot$ & • & 2 & 2 & $\dot{*}_{i}$ & $\begin{array}{c}1 \\
\cdot\end{array}$ & ${ }^{1}$ & ${ }^{3}$ & $\cdot$ & $\cdot \overrightarrow{3}$ & $\dot{i}^{2}$ & : & • \\
\hline $\begin{array}{l}\text { Cocconeis antiqua } \\
\text { C. californica } \\
\text { C. costata } \\
\text { C. scutellum } \\
\text { C. vitrea }\end{array}$ & $\dot{0}$ & $\dot{:}$ & $\begin{array}{l}1 \\
1 \\
1 \\
1\end{array}$ & : & $\dot{.}$ & : & $\dot{1}$ & $\cdot$ & $\cdot$ & : &.$^{2}$ & $\cdot \cdot \cdot$ & $\cdot 1$ & : & : & 1 & $:$ & $\cdot$ & $\begin{array}{l}\cdot \\
\cdot\end{array}$ & • & & : & $\dot{*}$ & $\cdot$ \\
\hline $\begin{array}{l}\text { Coscinodiscus endoi \& tabularis } \\
\text { C. marginatus } \\
\text { C. nodulifer } \\
\text { C. cf. nodulifer \& sp. A } \\
\text { C. symbolophorus }\end{array}$ & $\cdot$ & . & - & $\cdot$ & $\dot{.}$ & & - & $\cdot$ & $\dot{1}$ & : & 1 & $\cdot$ & - & 2 & 2 & 1 & 3 & + & 9 & $! 1$ &.$^{8}$ & $\begin{array}{l}5 \\
1\end{array}$ & 5 & 16 \\
\hline $\begin{array}{l}\text { Cosmiodiscus insignis } \\
\text { Cymatosira debyi }\end{array}$ & • & & & & & & & & & : & & 1 & : & & & 3 & 2 & 2 & 2 & & & • & - & : \\
\hline $\begin{array}{l}\text { Delphineis cf. angustata } \\
\text { D. cf. ischaboensis } \\
\text { D. simonsenii }\end{array}$ & 1 & $\cdot$ & 1 & $\cdot$ & • &.$^{1}$ & 1 & $\begin{array}{l}1 \\
5\end{array}$ & $\cdot$ & 2 & 1 & $\begin{array}{l}1 \\
1\end{array}$ & &.$^{3}$ & $\cdot$ & $\begin{array}{r}1 \\
13\end{array}$ & 15 & 7 & $\begin{array}{l}3 \\
9\end{array}$ & $\begin{array}{l}* \\
13\end{array}$ & $\begin{array}{l}2 \\
4\end{array}$ & $\begin{array}{l}1 \\
6\end{array}$ & $\cdot$ & 1 \\
\hline $\begin{array}{l}\text { D. surirella } \\
\text { D. sheshukovae n. sp. } \\
\text { Denticulopsis dimorpha } \\
\text { D. hustedtii s.1. } \\
\text { D. hyalina }\end{array}$ & 1 & 1 & • & 1 & • & - & 1 & & $\cdot$ & . & & • & & & & & & & • & & & 1 & & • \\
\hline $\begin{array}{l}\text { D. praedimorpha } \\
\text { Neodenticula kamtschatica } \\
\text { Grammatophora spp. } \\
\text { Hemidiscus cuneiformis } \\
\text { H. ovalis }\end{array}$ & 51 & $\dot{*}_{1}^{61}$ & $\begin{array}{l}59 \\
\text {. }\end{array}$ & $\begin{array}{l}69 \\
:\end{array}$ & $\stackrel{69}{\cdot}$ & 74 & ${ }^{80}$ & $\begin{array}{l}66 \\
-\end{array}$ & ${ }^{67}$ & $\begin{array}{l}46 \\
:\end{array}$ & $\dot{6}^{62}$ & $\dot{36}$ & $\stackrel{43}{*}$ & $\stackrel{44}{*}$ & 58 & $\begin{array}{r}34 \\
1 \\
.\end{array}$ & 59 & :33 & 48 & $\begin{array}{r}35 \\
1\end{array}$ & 39 & $\begin{array}{r}56 \\
1\end{array}$ & : & $\begin{array}{r}23 \\
\cdot^{1}\end{array}$ \\
\hline $\begin{array}{l}\text { Hyalodiscus obsoletus } \\
\text { Ikebea tenuis } \\
\text { Melosira albicans } \\
\text { Nitzschia cylindrus } \\
\text { N. fossilis }\end{array}$ & $\cdot$ & •. & - & 9 & ${ }^{9}$ & - &.$^{1}$ & & 3 & $\begin{array}{c}2 \\
\cdot\end{array}$ &.$^{3}$ & . & 2 & ${ }^{4}$ & $\begin{array}{r}1 \\
\cdot\end{array}$ & ${ }^{4}$ & 2 & $\begin{array}{l}2 \\
1\end{array}$ & + & 4 & $\begin{array}{l}2 \\
1\end{array}$ & - & • & 1 \\
\hline $\begin{array}{l}\text { N. jouseae } \\
\text { N. marina } \\
\text { N. miocenica } \\
\text { N. pliocena } \\
\text { N. reinholdii }\end{array}$ & - & • & - & • & - & - & : & • & • & • & $\cdot$ & : & $\cdot$ & • & $\cdot$ & • & • & $\cdot$ & • & • & & . & 1 & • \\
\hline $\begin{array}{l}\text { N. rolandii } \\
N . \text { sp. } 1 \text {. extincta } \\
\text { N. aff. extita } \\
\text { Odontella aurita }\end{array}$ & 2 & $\begin{array}{l}1 \\
1 \\
\vdots\end{array}$ & 2 & ${ }^{2}$ & 3 & $:^{3}$ & $\begin{array}{c}4 \\
.\end{array}$ & 3 & $\dot{*}$ & $\begin{array}{l}4 \\
1 \\
3\end{array}$ & $\dot{*}_{1}$ & ${ }^{3}$ & ${ }^{1}$ & 3 & $\vdots^{1}$ & 2 & $\cdot$ & $\begin{array}{l}1 \\
4\end{array}$ & 1 & $\begin{array}{c}\cdot \\
1 \\
\cdot\end{array}$ & $\begin{array}{l}1 \\
3 \\
\vdots\end{array}$ & $\begin{array}{l}4 \\
1\end{array}$ & $\begin{array}{l}1 \\
2 \\
.\end{array}$ & $\begin{array}{l}\dot{*}_{1} \\
.\end{array}$ \\
\hline $\begin{array}{l}\text { Paralia sulcata } \\
\text { Pseudopodosira elegans } \\
\text { Pseudopyxilla americana } \\
\text { P rossica } \\
\text { Rhabodonema japonicum } \\
\text { Rhaphoneis amphiceros }\end{array}$ & 2 & $\dot{\cdot}$ & . & $\begin{array}{l}\cdot \\
\cdot\end{array}$ & $\begin{array}{l}2 \\
1\end{array}$ & & $\dot{t}^{1}$ & • & $\begin{array}{l}1 \\
\text { • }\end{array}$ & . & 1 & 1 & - & 1 & $\dot{*}$ & 1 & • & • & & $*$ & ${ }_{1}^{*}$ & . & • & $\dot{*}_{1}$ \\
\hline
\end{tabular}

Note: Numbers represent individuals in routine 100 count: ${ }^{*}$ indicates presence of taxa. $* *=$ Rouxia californica. 


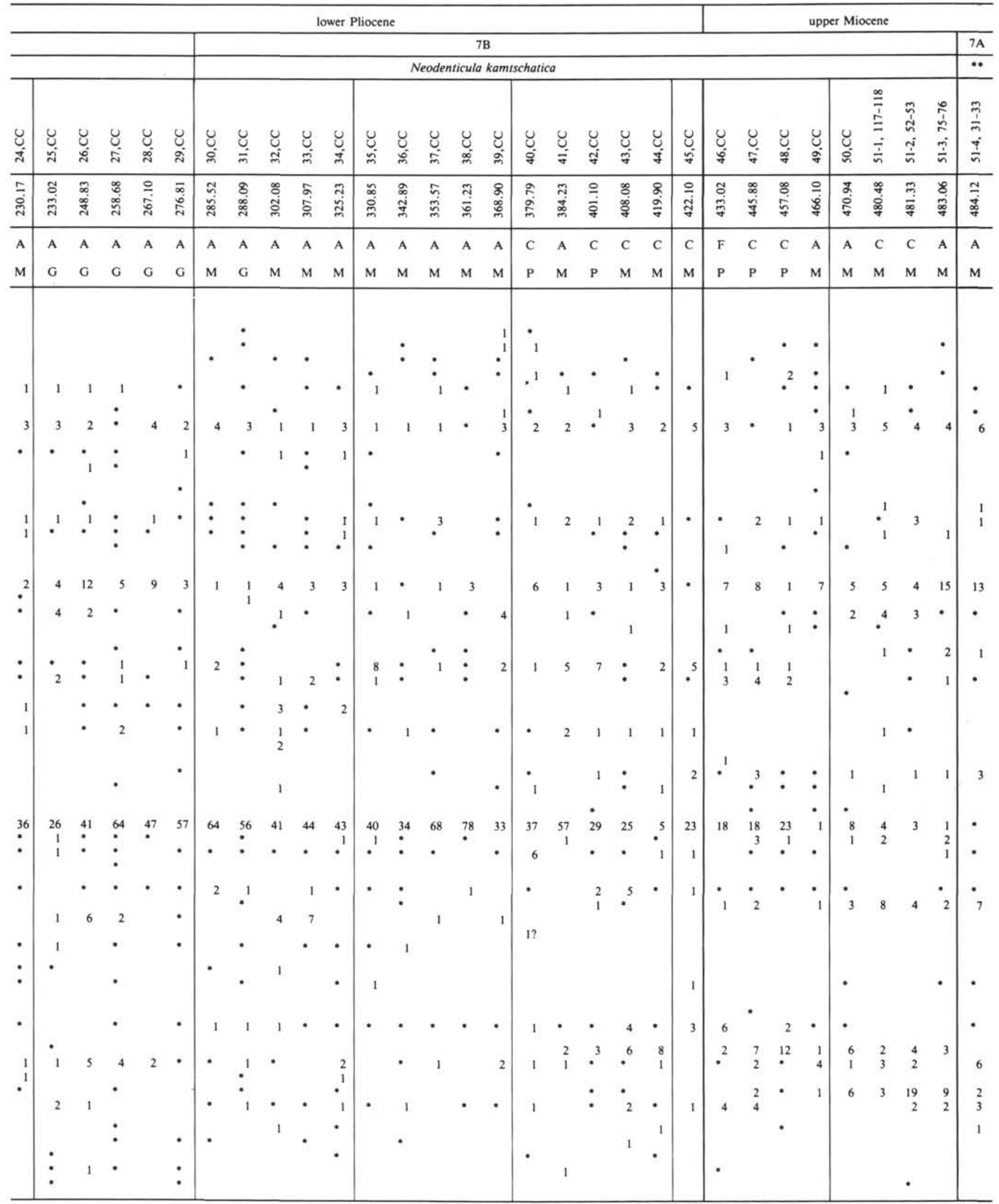


Table 6. (Continued).

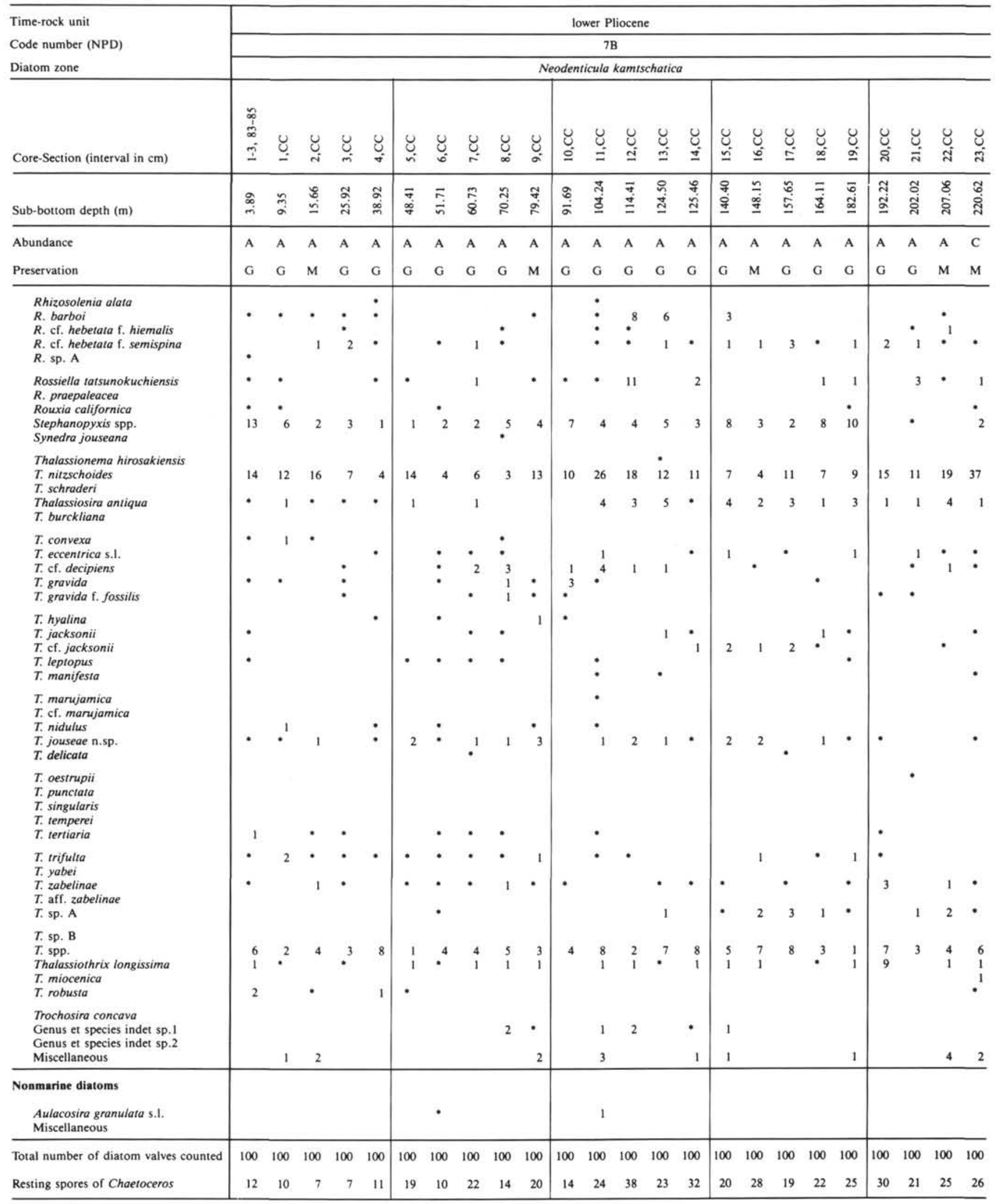




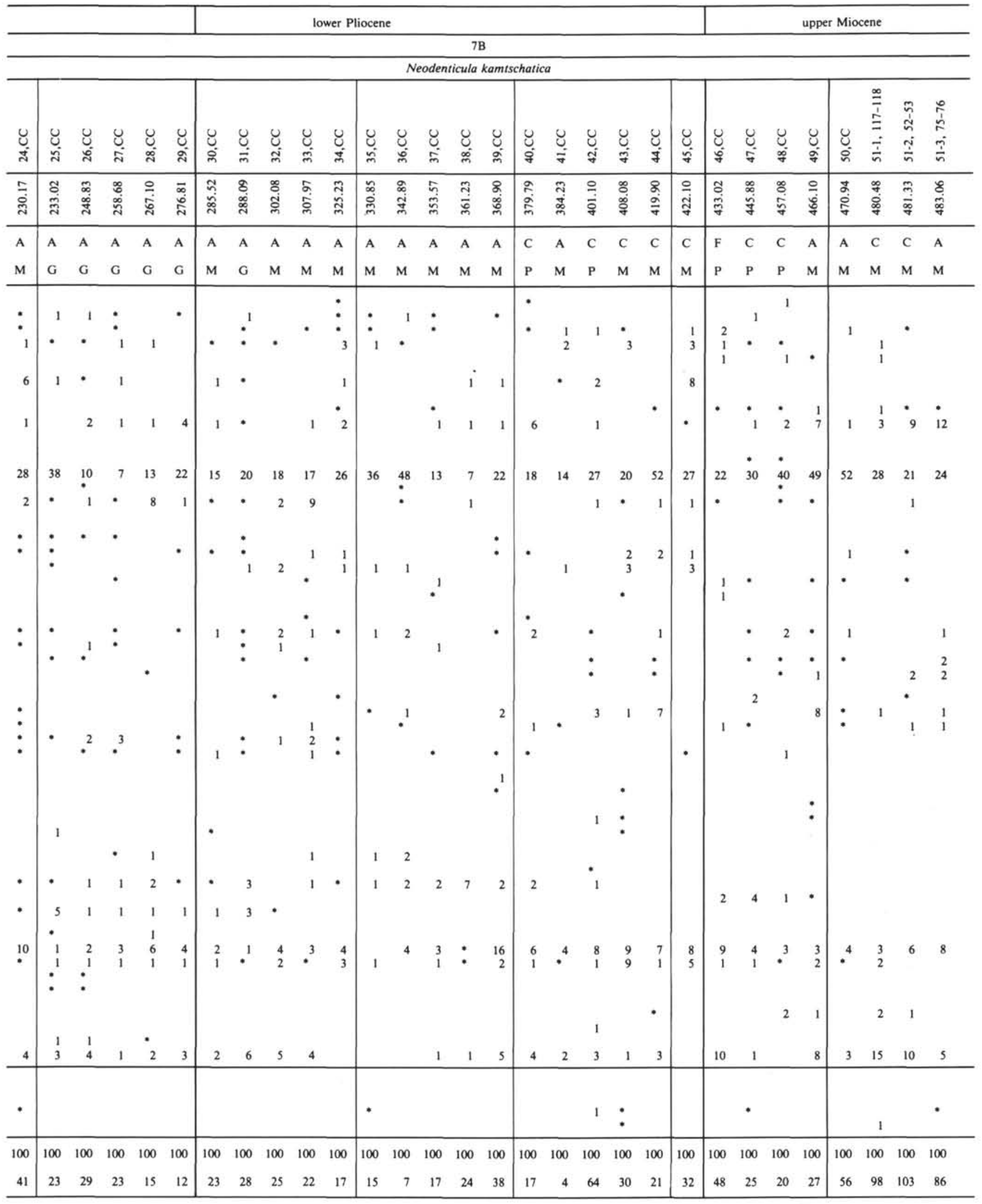


Table 6. (Continued).

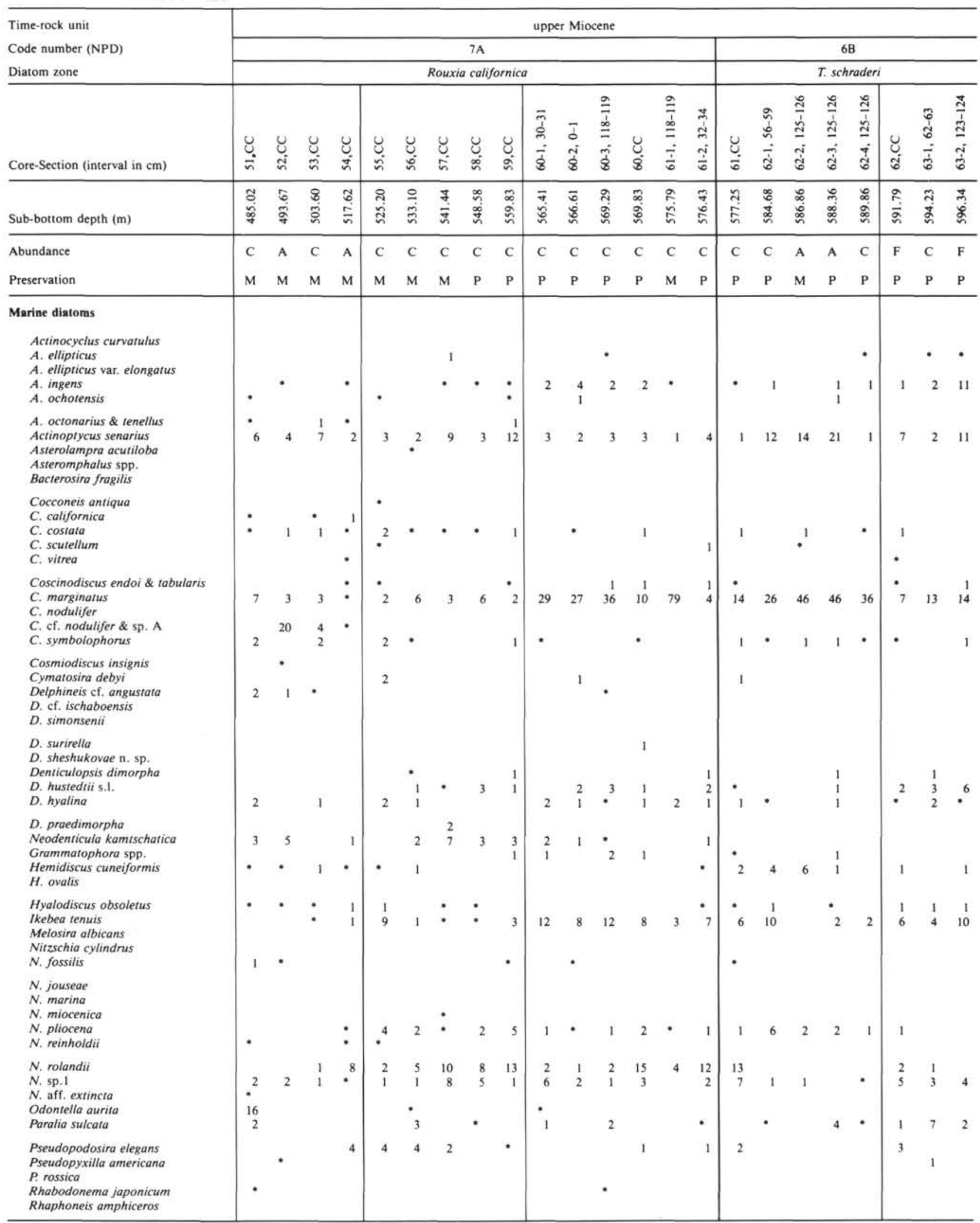


Table 6. (Continued).

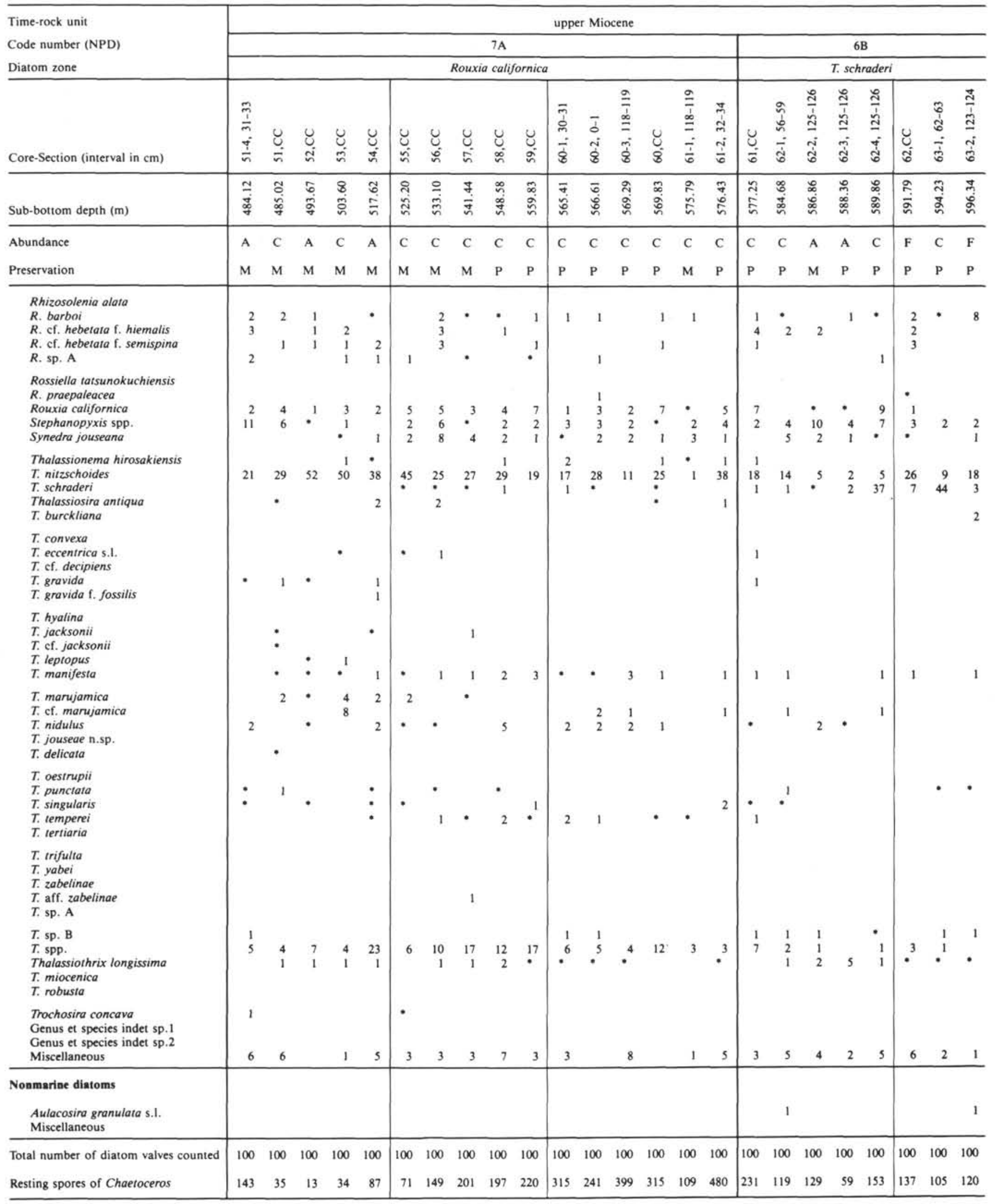


Table 7. Stratigraphic occurrence of diatoms in Hole 584 (upper Miocene through middle Miocene intervals).

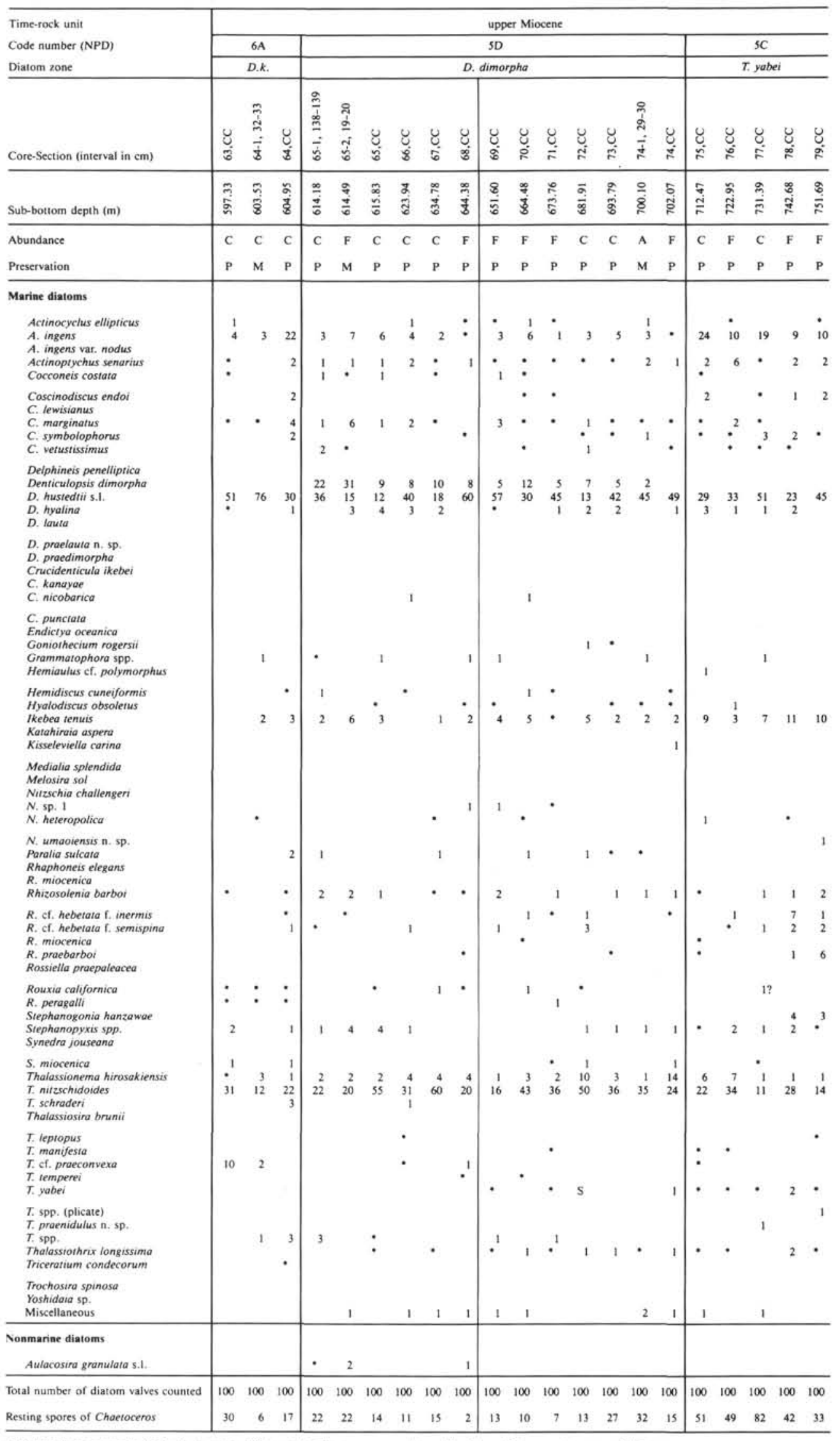


Table 7. (Continued).

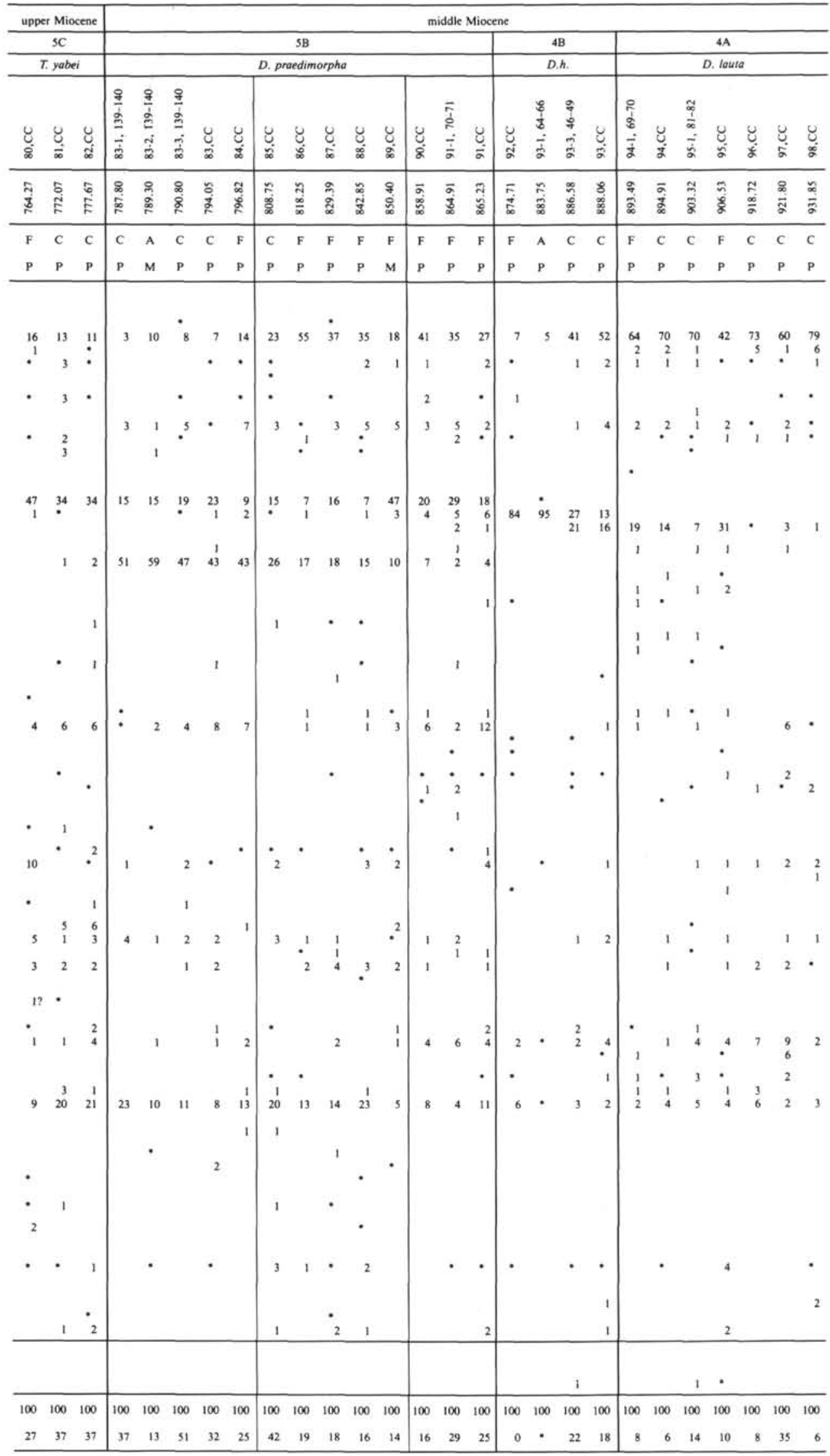




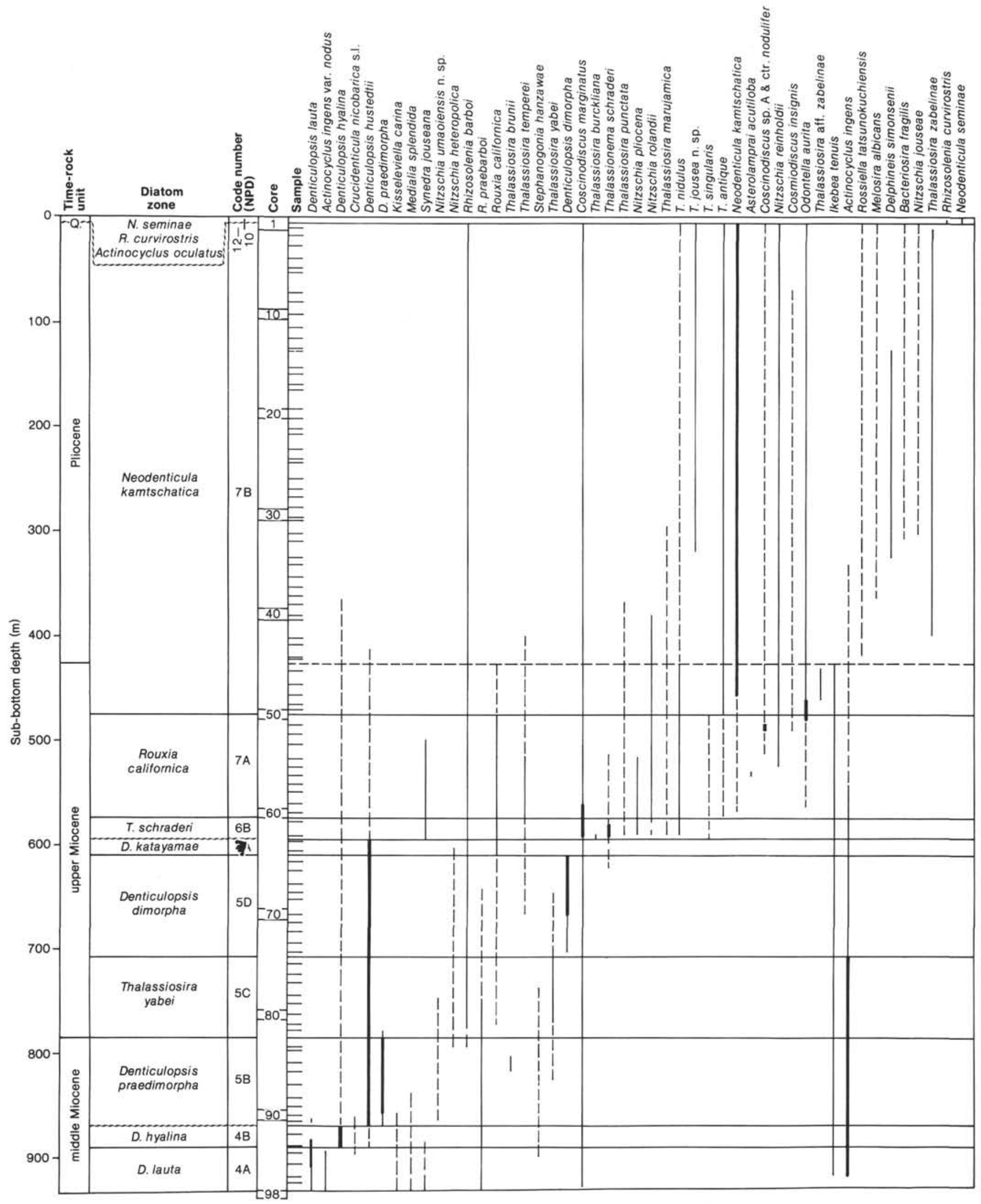

Figure 3. Stratigraphic occurrences of selected diatoms in Hole 584. Thick vertical bars indicate abundant to very abundant occurrences, thin vertical lines indicate frequent to common occurrences, and broken vertical lines indicate rare to sporadic occurrences, respectively. The dashed horizontal line marks the Miocene-Pliocene boundary and horizontal, wavy line segments indicate hiatuses. 
Table 8. Stratigraphic occurrence of diatoms in Holes 584A and 584B (Pliocene through middle Miocene intervals).

\begin{tabular}{|c|c|c|c|c|c|c|c|c|c|c|c|c|c|c|c|c|}
\hline \multirow{3}{*}{$\begin{array}{l}\text { Hole } \\
\text { Time-rock unit } \\
\text { Code number (NPD) }\end{array}$} & \multicolumn{9}{|c|}{$584 \mathrm{~A}$} & \multicolumn{7}{|c|}{$584 \mathrm{~B}$} \\
\hline & \multirow{2}{*}{\multicolumn{2}{|c|}{$\begin{array}{c}\text { I.P. } \\
78\end{array}$}} & \multicolumn{3}{|c|}{ u. Mio. } & \multicolumn{4}{|c|}{ m. Mio. } & \multicolumn{2}{|c|}{ P. } & \multicolumn{4}{|c|}{ u. Miocene } & \multirow{2}{*}{\begin{tabular}{|l}
$\mathrm{m}$. \\
$\mathrm{M}$. \\
$4 \mathrm{~A}$
\end{tabular}} \\
\hline & & & $5 \mathrm{I}$ & D & $5 \mathrm{C}$ & 5B & 4 & BB & $4 \mathrm{~A}$ & 71 & B & 7. & A & $6 \mathrm{~A}$ & $5 \mathrm{C}$ & \\
\hline Diatom zone & \multicolumn{2}{|c|}{ N. $k$. } & \multicolumn{2}{|c|}{ D. $d$. } & $\begin{array}{l}T . \\
y .\end{array}$ & $\begin{array}{l}D . \\
\text { p. }\end{array}$ & \multicolumn{2}{|c|}{ D. $h$. } & $\begin{array}{l}D . \\
\text { l. }\end{array}$ & \multicolumn{2}{|c|}{ N. $k$. } & \multicolumn{2}{|c|}{ R. c. } & $\begin{array}{l}D . \\
k .\end{array}$ & $\begin{array}{l}T . \\
y .\end{array}$ & D. \\
\hline Core-Section (interval in $\mathrm{cm}$ ) & $\begin{array}{l}\vec{m} \\
\frac{m}{d} \\
\frac{0}{a} \\
\frac{1}{x}\end{array}$ & 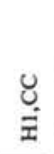 & $\underset{-}{0}$ & $\begin{array}{l}\text { U } \\
\text { İ }\end{array}$ & 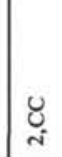 & 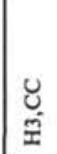 & $\underset{m}{\mathbb{m}}$ & 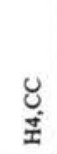 & $\frac{u}{\dot{x}}$ & $\begin{array}{l}\frac{9}{2} \\
\text { g } \\
\frac{1}{ \pm}\end{array}$ & U & $\begin{array}{l}\text { U } \\
\text { đ̃ }\end{array}$ & $\underset{N}{U}$ & $\begin{array}{l}\text { U } \\
\ddot{x}\end{array}$ & 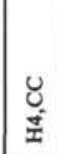 & 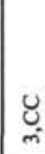 \\
\hline Sub-bottom depth (m) & $\begin{array}{l}\bar{\alpha} \\
\infty \\
\infty\end{array}$ & $\stackrel{\infty}{\circ}$ & సે & $\begin{array}{l}\frac{2}{0} \\
\frac{0}{6}\end{array}$ & 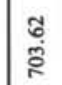 & $\stackrel{\text { ñ }}{\stackrel{\Sigma}{\hbar}}$ & $\begin{array}{l}\frac{a}{0} \\
\stackrel{\circ}{\circ}\end{array}$ & $\underset{\infty}{\stackrel{\bar{\infty}}{\bar{\infty}}}$ & $\underset{\infty}{\sim}$ & $\stackrel{\infty}{-}$ & a & $\begin{array}{l}\infty \\
\infty \\
\sim \\
\sim\end{array}$ & శ్తి & 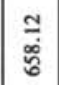 & శ্ণ & $\begin{array}{l}\text { శ్రి } \\
\text { హু }\end{array}$ \\
\hline Abundance & A & $\mathrm{C}$ & $\mathrm{C}$ & C & c & $\mathrm{C}$ & $\mathrm{C}$ & A & F & A & $\mathrm{C}$ & $\mathrm{C}$ & $\mathrm{C}$ & C & $\mathrm{C}$ & c \\
\hline Preservation & $\mathrm{P}$ & $P$ & M & M & P & $\mathrm{P}$ & M & $\mathrm{M}$ & $\mathbf{P}$ & G & G & G & $\mathbf{P}$ & M & M & $\mathbf{P}$ \\
\hline Marine diatoms & & & & & & & & & & & & & & & & \\
\hline $\begin{array}{l}\text { Actinocyclus ellipticus } \\
\text { A. ellipticus f. lanceolatus } \\
\text { A. ingens } \\
\text { A. ingens var. nodus } \\
\text { Actinoptychus senarius }\end{array}$ & 2 & 1 & 5 & $\begin{array}{l}6 \\
1\end{array}$ & $\begin{array}{l}4 \\
3\end{array}$ & 19 & 8 & $\begin{array}{l}2 \\
1\end{array}$ & 63 & - & - & 1 & $\begin{array}{l}1 \\
6\end{array}$ & $\begin{array}{l}17 \\
\cdot\end{array}$ & $\begin{array}{l}12 \\
\cdot\end{array}$ & ${ }^{67}$ \\
\hline $\begin{array}{l}\text { Coscinodiscus marginatus } \\
\text { C. sp. A } \\
\text { Cosmiodiscus insignis } \\
\text { Crucidenticula kanayae } \\
\text { C. nicobarica }\end{array}$ & $\begin{array}{r}24 \\
1\end{array}$ & 3 & 1 & 4 & 2 & 2 & 1 & . & 2 & $\cdot$ & 13 & $\stackrel{11}{\vdots}$ & $\begin{array}{r}31 \\
1\end{array}$ & 19 & 2 & • \\
\hline $\begin{array}{l}\text { Denticulopsis dimorpha } \\
\text { D. hustedtii s.1. } \\
\text { D. hyalina } \\
\text { D. lauta } \\
\text { D. miocenica }\end{array}$ & & & $\begin{array}{r}27 \\
8 \\
9\end{array}$ & $\begin{array}{r}10 \\
29 \\
1\end{array}$ & $\begin{array}{r}55 \\
3\end{array}$ & $\begin{array}{l}29 \\
19\end{array}$ & $\begin{array}{r}78 \\
2\end{array}$ & $\dot{7}_{3}$ & 11 & & - & $\cdot$ & $\begin{array}{l}1 \\
3\end{array}$ & $\begin{array}{r}30 \\
1\end{array}$ & $\begin{array}{r}61 \\
4\end{array}$ & 5 \\
\hline $\begin{array}{l}\text { D. praedimorpha } \\
\text { D. praelauta } \mathrm{n} . \mathrm{sp} \text {. } \\
\text { Neodenticula kamtschatica } \\
\text { Hemidiscus cuneiformis } \\
\text { Ikebea tenuis }\end{array}$ & & $\begin{array}{r}46 \\
3\end{array}$ & 3 & $\dot{\bullet}$ & : & 2 & 1 & & 1 & $\begin{array}{r}63 \\
1\end{array}$ & $\begin{array}{r}30 \\
3\end{array}$ & $\begin{array}{l}2 \\
3\end{array}$ & $\begin{array}{l}2 \\
1\end{array}$ & $\dot{14}_{14}$ & 3 & 2 \\
\hline $\begin{array}{l}\text { Kisseleviella carina } \\
\text { Paralia sulcata } \\
\text { Nitzschia jouseae } \\
\text { N. reinholdii } \\
\text { N. rolandii }\end{array}$ & & 2 & & 1 & & 4 & • & $\cdot$ & • & $\dot{0}^{2}$ & ${ }^{2}$ & 4 & 7 & & 3 & 1 \\
\hline $\begin{array}{l}\text { N. umaoiensis n. sp. } \\
\text { Rhizosolenia barboi } \\
\text { R. praebarboi } \\
\text { Rouxia californica } \\
\text { Stephanopyxis spp. }\end{array}$ & & 1 & $\begin{array}{l}2 \\
2\end{array}$ & $\stackrel{2}{1}^{1}$ & 1 & $\begin{array}{l}3 \\
1 \\
1\end{array}$ & 1 & 1 & 4 & • & • & $\begin{array}{l}1 \\
3\end{array}$ & $\begin{array}{r}15 \\
3 \\
2\end{array}$ & 1 & * & \\
\hline $\begin{array}{l}\text { Synedra jouseana } \\
\text { Thalassionema hirosakiensis }\end{array}$ & & & 3 & 4 & 6 & & • & & & & & & $\begin{array}{l}1 \\
1\end{array}$ & & & 10 \\
\hline $\begin{array}{l}\text { T. nitzschioides } \\
\text { T. schraderi } \\
\text { Thalassiosira antiqua }\end{array}$ & $\begin{array}{l}7 \\
2\end{array}$ & 8 & $\begin{array}{r}34 \\
1\end{array}$ & 36 & 16 & 13 & 7 & 13 & 4 & 11 & 20 & $\begin{array}{r}55 \\
1 \\
1\end{array}$ & 12 & 9 & 8 & 1 \\
\hline $\begin{array}{l}\text { T. gravida } \\
\text { T. manifesta } \\
\text { T. cf. marujamica } \\
\text { T. nidulus } \\
\text { T. singularis }\end{array}$ & & & & & & & & & & 1 & 4 & $\begin{array}{l}\dot{4}^{4} \\
\dot{1}^{\prime}\end{array}$ & & 1 & & \\
\hline $\begin{array}{l}\text { T. trifulta } \\
\text { T. yabei } \\
\text { T. zabelinae }\end{array}$ & $\begin{array}{l}2 \\
2\end{array}$ & 1 & & & & & & & & 1 & & & & & 1 & \\
\hline $\begin{array}{l}T \text {. spp. } \\
\text { Miscellaneous }\end{array}$ & $\begin{array}{l}10 \\
16\end{array}$ & 5 & 1 & 2 & 1 & 7 & 2 & 3 & 12 & 7 & 6 & 2 & 1 & 1 & 6 & 11 \\
\hline $\begin{array}{l}\text { Nonmarine diatom } \\
\qquad \text { Aulacosira granulata s.l. }\end{array}$ & & & & 1 & & - & & - & 1 & & & & & & & \\
\hline Total number of diatom valves counted & 100 & 100 & 100 & 100 & 100 & 100 & 100 & 100 & 100 & 100 & 100 & 100 & 100 & 100 & 100 & 100 \\
\hline Resting spores of Chaetoceros & 36 & 25 & 23 & 34 & 47 & 32 & 10 & 3 & 11 & 22 & 78 & 41 & 141 & 43 & 18 & 24 \\
\hline
\end{tabular}

Note: Numbers represent individuals in routine 100 count; ${ }^{*}$ indicates presence of taxa. See Figure 2 for complete names of diatom zones. 


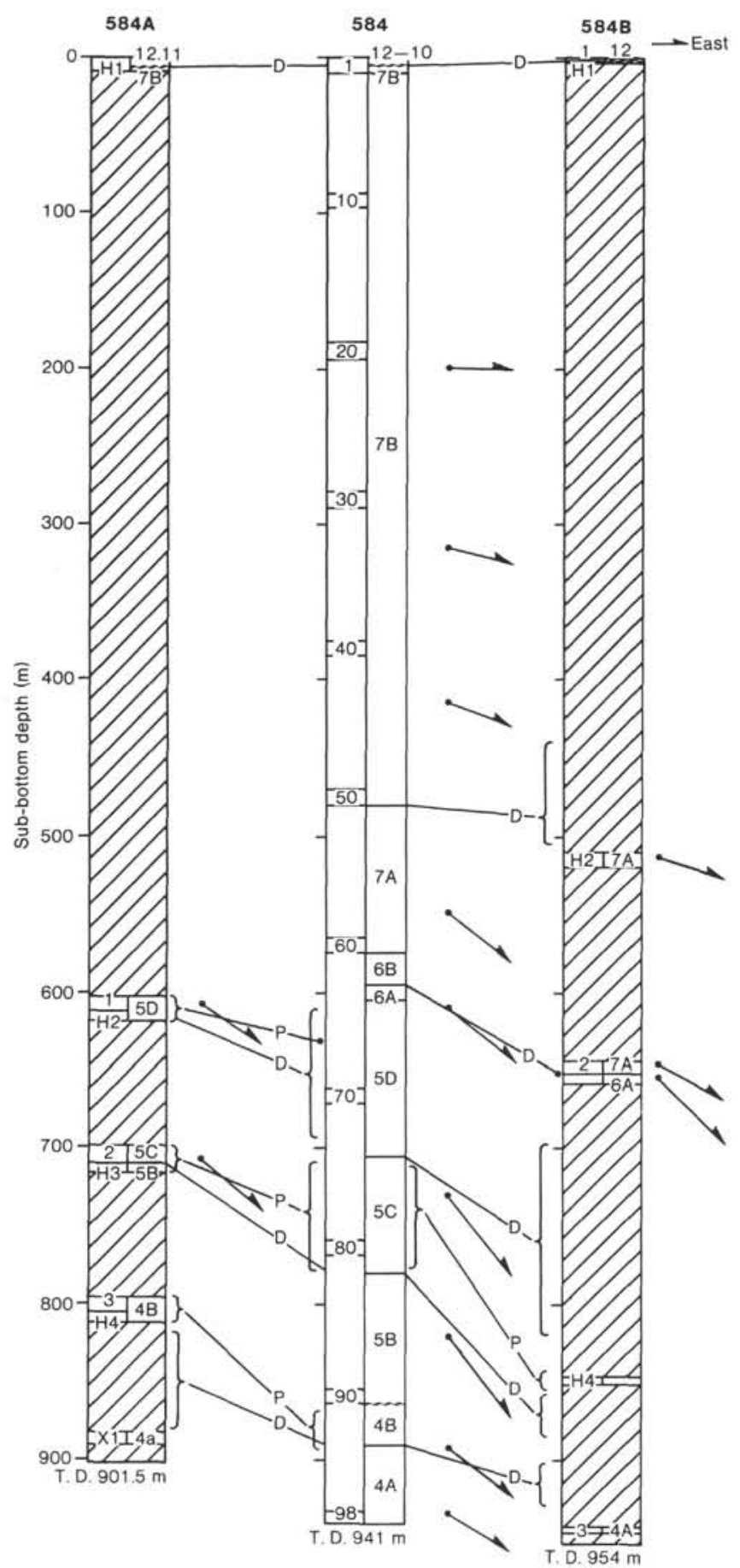

Figure 4. Correlation of Site 584 holes by diatom zones (D) and paleomagnetic polarity patterns (P). Arrow indicates dip angle of sediment as measured by Niitsuma (this volume). In the Hole 584 column, $4 \mathrm{~A}$ to $12-10$ refer to diatom zonation (Fig. 3). Diagonally ruled portions of Holes 584A and 584B were not cored. T.D. = total depth.

latitudes of the North Pacific, namely the upper Quaternary Neodenticula seminae Zone (NPD12) through the lower Miocene Denticulopsis praelauta Zone (NPD3B) (Barron, 1980a; zonal names modified in this chapter), which are represented by well-preserved and abundant diatom assemblages in general, and (2) it yielded both high-latitude and low-latitude diatoms in the upper Miocene through the Quaternary, although the latter are rare. That mixture allowed the first direct correlation of low-latitude and high-latitude zonations for the upper Miocene (Barron, 1980a). Accordingly, the diatom biostratigraphy of this hole was repeatedly examined after Barron's study (Akiba et al., 1982; Akiba, 1982a; Maruyama, 1984).

Selected samples from this hole, Samples 438A-41,CC through 438A-70-7, 5-7 cm, were reexamined in order to directly correlate Barron's (1980a) zonation with that proposed in this chapter and to examine relative frequencies of low-latitude species and other species that were not treated by Barron (1980a).

All the samples exammed yield abundant diatom assemblages, most of which are moderately well or well preserved (Table 9: note, number of diatom valves counted is not 100 but 300 ). Sample $438 \mathrm{~A}-41, \mathrm{CC}$ is assigned to the Neodenticula kamtschatica Zone (NPD7B), which is characterized by common occurrence of $N$. kamtschatica. Nitzschia miocenica, a warm-water species, occurs in this sample. Samples 438A-42-1, 90-91 cm through 438A-42,CC belong to the Rouxia californica Zone (NPD7A), the top of which is marked by an uphole sudden decrease of $R$. californica. Rare occurrences of NeOdenticula kamtschatica in this zone are represented by smaller specimens, which in some cases are difficult to distinguish from Nitzschia rolandii. A short acme of Coscinodiscus sp. A, recognized in Hole 584, is also recognized in two samples (438A-42-2, 95-96 cm and 438A$42-3,15-16 \mathrm{~cm}$ ) from this hole. Odontella aurita is common and nearly confined to this zone. The last occurrence of Nitzschia pliocena is in Sample 438A-42-2, $95-96 \mathrm{~cm}$; its last common occurrence is in Sample 438A-42-4, 73-74 cm. An interval from 438A-43,CC through $438 \mathrm{~A}-50-7,10-11 \mathrm{~cm}$ is assigned to the Thalassionema schraderi Zone (NPD6B), the top of which is marked by the last occurrence of $T$. schraderi; this species is common to abundant throughout the zone. Thalassiosira burckliana, a tropical species, occurs in limited numbers in two samples of this zone (438A-48-7, $30-31 \mathrm{~cm}$ and $438 \mathrm{~A}-49-7,10-11 \mathrm{~cm})$. The first occurrences of $N$. pliocena and $T$. singularis are recognized in Samples 438A-46-7, 20-21 cm and 438A-44,CC, respectively. The last occurrence of $T$. cf. praeconvexa is in Sample 438A-46-7, 20-21 cm; its last common occurrence is in Sample 438A-49-7, 10-11 cm. Resting spores of Chaetoceros and its allied forms occur very abundantly throughout this zone and also in the lowermost sample of the overlying $R$. californica Zone. Samples from 438A-51-7, 10-11 cm through 438A-55-6, 76-78 cm belong to the Denticulopsis katayamae Zone (NPD6A). The sudden uphole decrease of $D$. hustedtii s.l. (including $D$. katayamae) marks the top of Zone NPD6A. $D$. katayamae is abundant in this zone. The $D$. dimorpha Zone (NPD5D) occupies an interval from 438A-56,CC through $438 \mathrm{~A}-59-5,5-6 \mathrm{~cm}$ based on the common and limited occurrence of the nominate species. D. katayamae first occurs in the middle part of this zone at 438A-58-3, 19-21 cm. The first common occurrence of $T$. cf. praeconvexa is at $438 \mathrm{~A}-56, \mathrm{CC}$. Samples from 
438A-60-3, 26-27 cm through 438A-63-1, 87-88 cm are assigned to the T. yabei Zone (NPD5C), the top of which is marked by a horizon just below the first occurrence of D. dimorpha. Assemblages of this zone are dominated by $D$. hustedtii, and the occurrences of T. yabei, T. urahoroensis $\mathrm{n}$. sp., and $T$. praenidulus $\mathrm{n}$. $\mathrm{sp}$. are restricted to this zone. The $D$. praedimorpha Zone (NPD5B) occurs in Samples 438A-64-7, 34-35 cm through 438A$66-2,34-36 \mathrm{~cm}$. Both $D$. hustedtii and $D$. praedimorpha are common to abundant, and the latter species is confined to this zone. The last occurrences of Crucidenticula nicobarica and Nitzschia challengeri are in Samples 438A-66-1, 12-13 cm and 438A-65-7, 17-18 cm, respectively. Rhizosolenia barboi first occurs in this zone, in Sample 438A-65-7, 17-18 cm. Sample 438A-66-2, 82-84 $\mathrm{cm}$ belongs to the $C$. nicobarica Zone (NPD5A), its top represented by a horizon just below the first occurrence of $D$. praedimorpha. It is characterized by the common occurrences of both $D$. hustedtii and $C$. nicobarica. The first common occurrence of $D$. hustedtii and a sudden uphole decrease in the frequency of $D$. hyalina mark the base of this zone. The last occurrence of $D$. lauta is in this zone. Samples 438A-67-1, 112-133 cm through 438A70-7, 5-7 cm belong to the $D$. hyalina Zone (NPD4B), which is characterized by common to abundant occurrences of $D$. hyalina and $D$. lauta. The last common occurrence of $D$. lauta is in Sample 438A-68-7, 24-26 cm, and an assemblage from its superjacent sample (Sample $438 \mathrm{~A}-67-1,112-113 \mathrm{~cm}$ ) is almost monospecific, represented by a mass occurrence of $D$. hyalina.

As a result of this reexamination of selected samples from Hole $438 \mathrm{~A}$, all the diatom zones recognized in Hole 584 are also identified in this hole, allowing a correlation of Barron's (1980a) zonation directly with that proposed in this chapter (Figs. 5 and 6). Zonal boundaries recognized in this study are very similar to those of Barron (1980a). Differences in these two zonations arise from different recognition of occurrences of particular diatoms or datums, which will be described in more detail in a following section, "Modified Neogene Diatom Zonation."

On the other hand, many low-latitude diatoms recognized by Barron (1980a), which are used in the low-latitude diatom zonation by Burckle $(1972,1977)$ (one with good paleomagnetostratigraphic controls), especially from the upper Miocene through the lower Pliocene sequences of this hole, were not detected in the present analyses. Of those that are recognized, most are too sporadic to allow precise recognition of their total ranges. Differences in identification of the low-latitude species between these two studies are probably caused by the different methods used (Barron, 1980a, observed much greater numbers of specimens per sample than those studied in this chapter). The low-latitude species occur in this hole very rarely even if Barron's method is used. However, the stratigraphic ranges of those species have been judged to be isochronous with species in the low-latitude area, because the stratigraphic relationship or succession between those species is identical with species in the low-latitude area (Barron, 1980a).

\section{Hole 439}

Hole 439 of Leg $57\left(40^{\circ} 37.61^{\prime} \mathrm{N}, 143^{\circ} 18.63^{\prime} \mathrm{E}\right.$; water depth $1656 \mathrm{~m}$ ) was drilled near Site 438 and reached a lower Miocene horizon which was not met at Site 438 (Barron, 1980a) nor at Site 584. Barron (1980a) reported an interesting assemblage from the interval, but neither prepared an occurrence chart of diatoms from this hole nor attempted to make any zonal assignments. Selected samples, therefore, were examined to clarify species composition of this diatom zone, the lowest recognized to be present near Japan. Among the 17 samples examined, the following 8 samples were omitted from the occurrence chart (Table 10) because they only contain very few poorly preserved fragments of Coscinodiscus and/ or Stephanopyxis species: 439-12-2, 13-15 cm; 439-13-3, 2-3 cm; 439-13-3, 112-113 cm; 439-14-3, 21-23 cm; $439-14-3,34-36 \mathrm{~cm}$; 439-15-4, 58-60 cm; 439-16-3, 81$83 \mathrm{~cm}$; and 439-19-1, 95-97 cm.

Sample $439-5-1,140-141 \mathrm{~cm}$ is assigned to the Denticulopsis lauta Zone (NPD4A) based on the presence of $D$. lauta and the absence of $D$. hyalina. The middle/lower Miocene boundary is placed at the base of this zone. Samples 439-7-4, 74-76 cm through 439-10-4, 29-30 cm belong to the $D$. praelauta Zone (NPD3B), which is characterized by common to abundant occurrences of $D$. praelauta $\mathrm{n}$. sp. without $D$. lauta. The last occurrence of Kisseleviella carina is in this zone, between Samples $439-7-4,74-76 \mathrm{~cm}$ and $439-8-6,49-52 \mathrm{~cm}$. This species is generally present up to the $D$. lauta Zone, and its last occurrence here might represent its last common occurrence (Koizumi, 1979). Because it lacks D. praelauta and contains Actinocyclus ingens, Sample 439-11-4, 31-34 cm is assigned to the Crucidenticula kanayae Zone (NPD3A), although C. kanayae itself is not observed in the sample. A hiatus separates Cores 439-11 and 439-12, and the lower part of the $A$. ingens Zone sensu Barron (1980a), which correlates with the main part of the $\mathrm{C}$. $\mathrm{ka}$ nayae Zone of this chapter, is missing. The interval from $439-17-2,12-13 \mathrm{~cm}$ through $439-20-3,22-24 \mathrm{~cm}$ is assigned to the Thalassiosira fraga Zone (NPD2). It is characterized by the occurrence of $T$. frag $a$ and the absence of both $A$. ingens and Thalassionema nitzschioides. Other characteristic diatoms in this interval include Actinocyclus sp. A, Coscinodiscus praenodulifer, C. symbolophorus, Kisseleviella carina, K. ezoensis n. sp., Pseudotriceratium chenevieri, and Synedra jouseana. It is noteworthy that a nonmarine diatom, Aulacosira granulata s.1., occurs very abundantly in this interval (20-30\%), suggesting deposition in an environment strongly influenced by the influx of river waters. The species is also recognized in higher intervals at Hole 439, although its relative frequency is far less than that in the Thalassiosira fraga Zone.

\section{Sites 183 and 192}

Site 183 is located near the northern edge of the Aleutian abyssal plain, western Gulf of Alaska $\left(52^{\circ} 34.30^{\prime} \mathrm{N}\right.$, $161^{\circ} 12.33^{\prime} \mathrm{W}$; water depth $4708 \mathrm{~m}$ ), and Site 192 is located at the northwestern end of the Emperor Seamount 
Table 9. Stratigraphic occurrence of diatoms in Hole 438A, Leg 57.

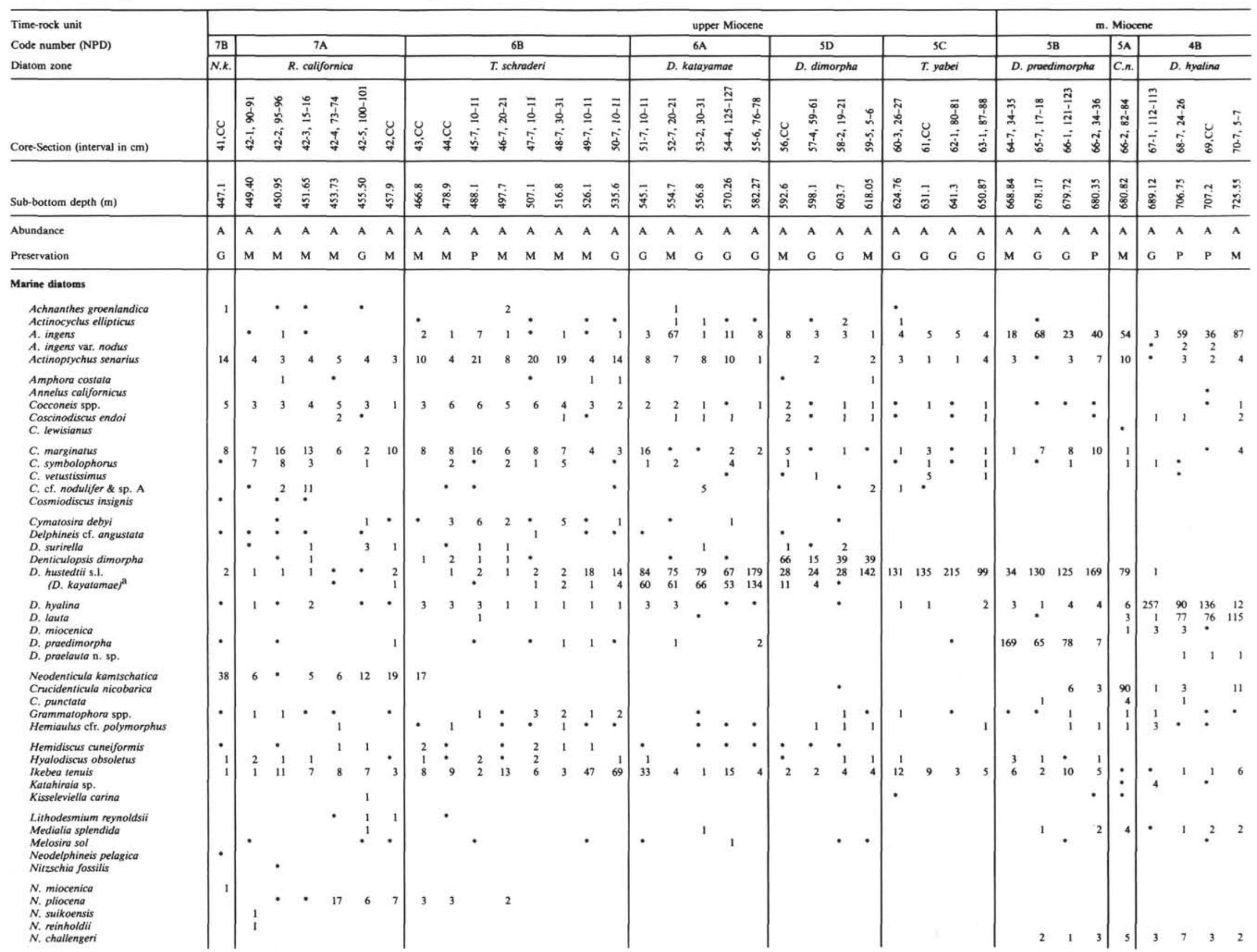




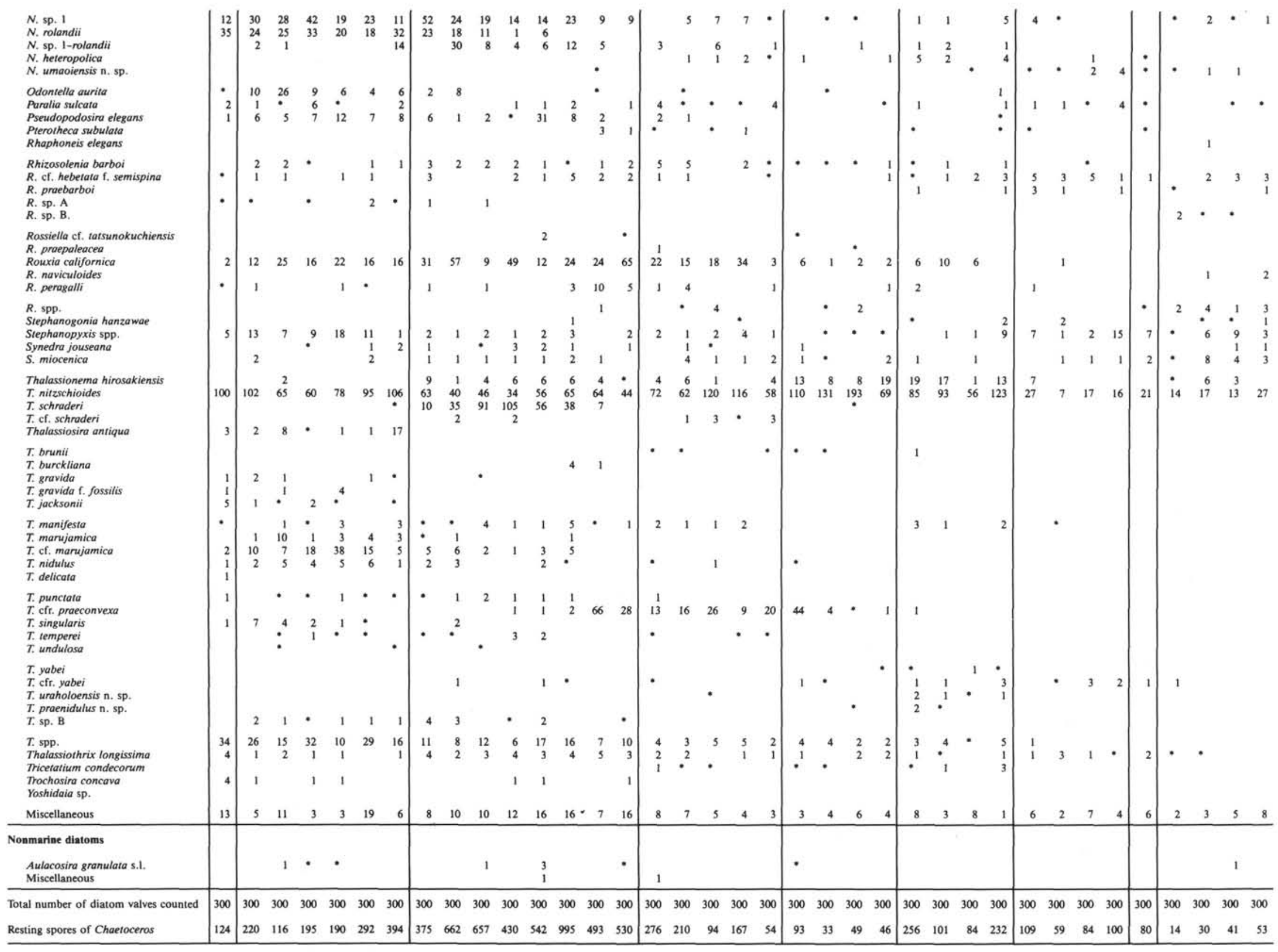




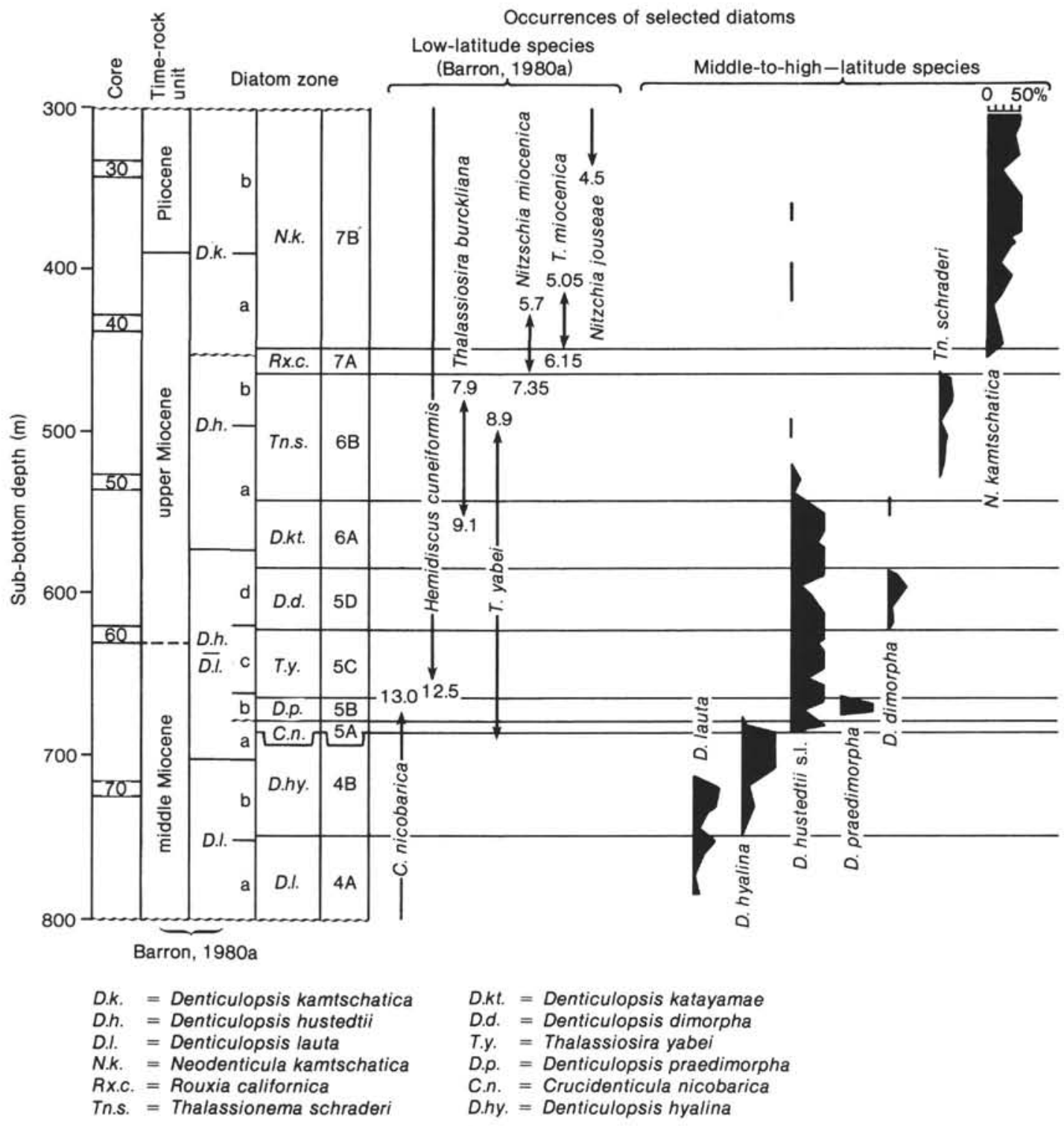

Figure 5. Comparison of diatom zonations of Hole 438A (Leg 57) between Barron (1980a) and this chapter, and occurrence of selected species of both low-latitude and middle-to-high-latitude diatom assemblages. Numbers for ranges of low-latitude species indicate estimated absolute ages suggested by Barron (1980a, in press a).

Chain $\left(53^{\circ} 00.57^{\prime} \mathrm{N}, 164^{\circ} 42.81^{\prime} \mathrm{E}\right.$; water depth $\left.3014 \mathrm{~m}\right)$. Diatom assemblages and biostratigraphy of these two Leg 19 sites were reported in detail by Koizumi (1973b). Several important diatom zonal marker species used in this chapter (such as Denticulopsis dimorpha, D. katayamae, and Thalassionema schraderi) were not incorporated in that analysis, because they are newly recognized diatoms. Selected samples from the above two highlatitude, North Pacific sites were reexamined to check for the presence of diatom zones comparable to those recognized in Holes 584 and 438A in the middle latitudes of the North Pacific. Koizumi kindly supplied selected samples from the originals he had examined (1973b).

All the samples examined from Site 183 contain very abundant diatom remains (Table 11), but mass occurrences of such dissolution-resistant species as Coscinodiscus marginatus, T. schraderi, or Actinocyclus ingens and very low diversity indicate poor preservation of all the samples. Samples from 183-17-1, 80-82 cm through 183-17,CC are assigned to the Neodenticula kamtschatica Zone (NPD7B). The interval is characterized by a mass occurrence of $C$. marginatus and common to frequent occurrences of $N$. kamtschatica and Thalassiosira aff. zabelinae. The Rouxia californica Zone (NPD7A) is recognized in Sample 183-18-2, 80-82 cm, although $R$. californica itself is not observed in the sample. This species is easily fragmented and not very resistant to dissolution. The diatom flora, characterized by such species as Nitzschia pliocena, T. singularis, and the extremely scarce Neodenticula kamtschatica, is ample enough to assign this sample to Zone NPD7A. Three samples from $183-18-3,80-82 \mathrm{~cm}$ through $183-18, C C$ clearly belong to the Thalassionema schraderi Zone (NPD6B), which is characterized by a mass occurrence of $T$. schraderi. The upper two samples of the zone contain exceptionally abundant and heavily silicified valves of $T$. schra- 
Hole 438A

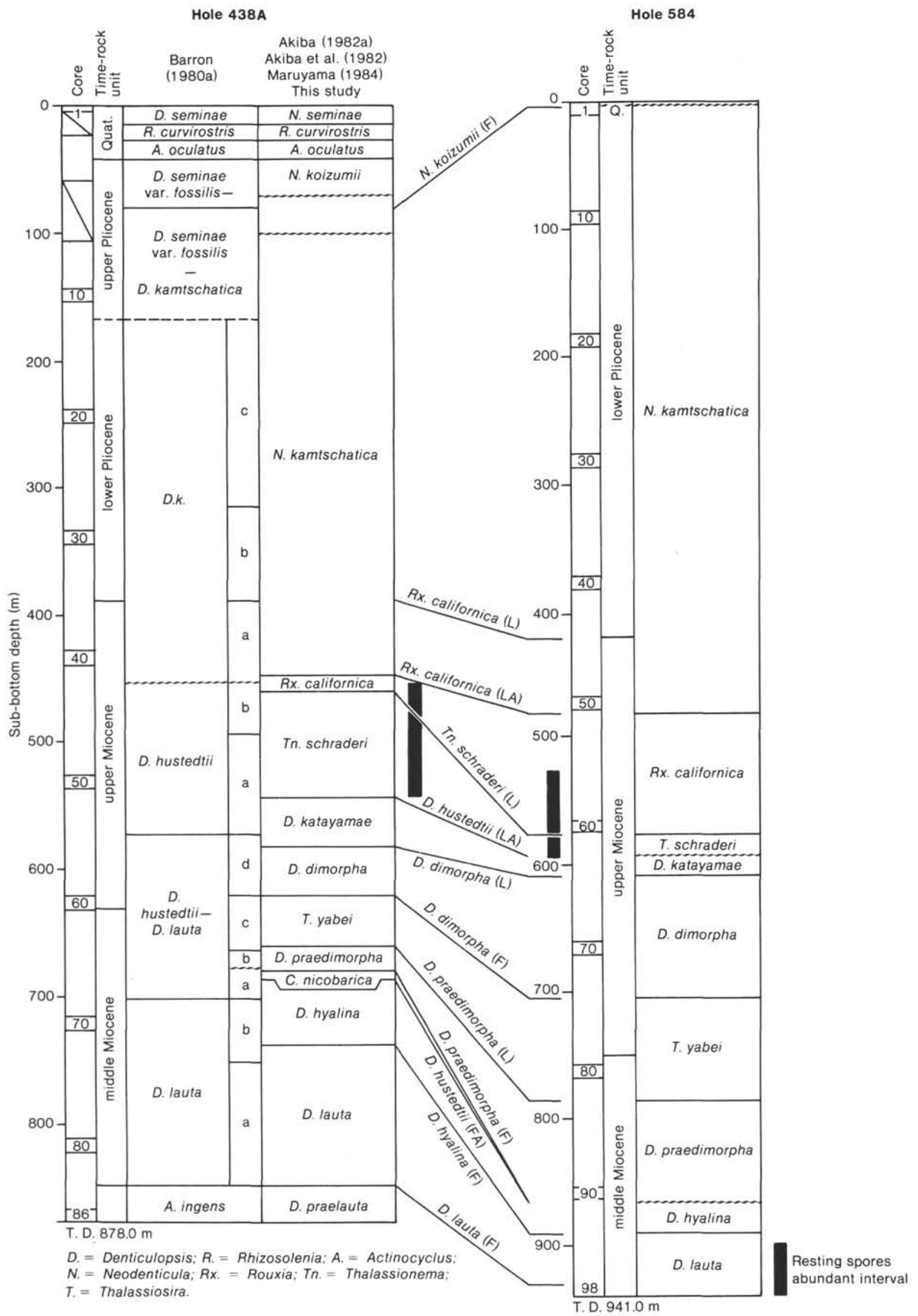

Figure 6. Correlation of Hole 438A with Hole 584 by diatom zones of this chapter. T.D. = total depth. 
Table 10. Stratigraphic occurrence of diatoms in Hole 439, Leg 57.

\begin{tabular}{|c|c|c|c|c|c|c|c|c|c|}
\hline Time-rock unit & m. & \multicolumn{8}{|c|}{ lower Miocene } \\
\hline Code number (NPD) & $4 \mathrm{~A}$ & \multicolumn{4}{|c|}{ 3B } & $3 \mathrm{~A}$ & \multicolumn{3}{|c|}{2} \\
\hline Diatom zone & D.I. & \multicolumn{4}{|c|}{ D. praelauta } & C.k. & \multicolumn{3}{|c|}{ T. fraga } \\
\hline Core-Section (interval in $\mathrm{cm}$ ) & $\begin{array}{l}\frac{\vec{a}}{d} \\
\frac{\partial}{a} \\
\bar{n}\end{array}$ & $\begin{array}{l}\stackrel{0}{1} \\
\frac{1}{2} \\
\dot{I} \\
i\end{array}$ & $\begin{array}{l}\text { Ñ } \\
\alpha \\
\alpha \\
0 \\
\infty\end{array}$ & 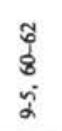 & 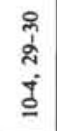 & $\begin{array}{l}\stackrel{ \pm}{1} \\
\frac{1}{m} \\
\dot{I} \\
=\end{array}$ & $\begin{array}{l}\frac{m}{d} \\
\check{I} \\
\stackrel{\Sigma}{\Xi}\end{array}$ & $\begin{array}{l}\tilde{n} \\
\tilde{n} \\
\tilde{n} \\
\tilde{\omega}\end{array}$ & 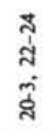 \\
\hline Abundance & A & A & A & C & C & $\mathbf{R}$ & $\mathbf{R}$ & $\mathbf{R}$ & $\mathbf{R}$ \\
\hline Preservation & M & $\mathbf{P}$ & M & $\mathbf{P}$ & $\mathbf{P}$ & $\mathbf{P}$ & $P$ & $\mathrm{P}$ & $\mathbf{P}$ \\
\hline \multicolumn{10}{|l|}{ Marine diatoms } \\
\hline $\begin{array}{l}\text { Actinocyclus ingens } \\
\text { A. octonarius } \\
\text { A. sp. A } \\
\text { Actinoptychus senarius } \\
\text { A. splendens }\end{array}$ & 3 & 48 & 11 & 39 & 36 & 38 & $\begin{array}{l}3 \\
3\end{array}$ & $\begin{array}{r}1 \\
\cdot^{3}\end{array}$ & $\dot{1}$ \\
\hline $\begin{array}{l}\text { Clavicula polymorpha } \\
\text { Cocconeis sp. } \\
\text { Coscinodiscus endoi } \\
\text { C. marginatus } \\
\text { C. oculus-iridis }\end{array}$ &.$^{3}$ & - & & 4 & 4 & 3 & $\begin{array}{l}1 \\
1\end{array}$ & 1 & \\
\hline $\begin{array}{l}\text { C. praenodulifer } \\
\text { C. symbolophorus } \\
\text { C. spp. } \\
\text { Delphineis penelliptica } \\
\text { Crucidenticula kanayae }\end{array}$ & $\cdot$ & • & $\dot{\bullet}$ & $\begin{array}{l}1 \\
\cdot\end{array}$ & $\begin{array}{r}2 \\
.\end{array}$ &.$^{1}$ & $\begin{array}{l}2 \\
5 \\
1\end{array}$ & $\ddot{1}_{4}$ & $\begin{array}{r}\cdot \\
4 \\
1\end{array}$ \\
\hline $\begin{array}{l}\text { Denticulopsis lauta } \\
\text { D. praelauta } \mathrm{n} . \mathrm{sp} . \\
\text { Diploneis spp. } \\
\text { Ethmodiscus sp. } \\
\text { Goniothecium rogersii }\end{array}$ & $\begin{array}{r}7 \\
58\end{array}$ & 21 & $\begin{array}{l}53 \\
:\end{array}$ & $\begin{array}{r}6 \\
\bullet\end{array}$ & $:^{7}$ & - & • & & \\
\hline $\begin{array}{l}\text { Grammatophora spp. } \\
\text { Hemiaulus bipons } \\
\text { Hyalodiscus obsoletus }\end{array}$ & & - & & & & & $\begin{array}{l}1 \\
1\end{array}$ & • & 7 \\
\hline $\begin{array}{l}\text { Ikebea temuis } \\
\text { Kisseleviella carina }\end{array}$ & 1 & 5 & $\dot{*}$ & $\begin{array}{l}13 \\
10\end{array}$ & $\begin{array}{l}10 \\
10\end{array}$ & 2 & $\begin{array}{r}9 \\
18\end{array}$ & $\begin{array}{r}1 \\
12\end{array}$ & $\begin{array}{l}11 \\
10\end{array}$ \\
\hline $\begin{array}{l}\text { K. ezoensis n. sp. } \\
\text { Medialia splendida } \\
\text { Melosina sol } \\
\text { Nitzschia challengeri } \\
\text { N. sp. } 1\end{array}$ & 2 & : & $\begin{array}{l}* \\
5\end{array}$ & $\dot{\bullet}$ & • & $\cdot \overrightarrow{4}$ & . & 7 & 5 \\
\hline $\begin{array}{l}\text { Odontella aurita } \\
\text { Paralia sulcata } \\
\text { Pseudotriceratium chenevieri } \\
\text { Pseudodimerogramma sp. } \\
\text { Rhaphoneis miocenica }\end{array}$ & • & 1 & & $\bullet$ & $\stackrel{*}{*}$ & 3 & $\begin{array}{l}5 \\
.\end{array}$ & : & \\
\hline $\begin{array}{l}R \text {. praebarboi } \\
R \text {. interposita } \\
R \text {. cf. hebetata f. semispina } \\
\text { Rouxia naviculoides } \\
\text { Stephanogonia cfr. hanzawae }\end{array}$ & ${ }_{1}^{*}$ & - & • & & $\cdot \begin{array}{c}1 \\
\cdot \\
2\end{array}$ & & & 1 & \\
\hline $\begin{array}{l}\text { Stephanopyxis spp. } \\
\text { Synedra jouseana } \\
\text { S. miocenica } \\
\text { Thalassionema hirasakiensis } \\
\text { T. nitzschioides }\end{array}$ & \begin{tabular}{r|}
$\cdot$ \\
1 \\
1 \\
2 \\
17
\end{tabular} & $\begin{array}{r}13 \\
1 \\
+\end{array}$ & 10 & $\begin{array}{r}8 \\
1 \\
10\end{array}$ & $\begin{array}{l}11 \\
+ \\
9\end{array}$ & $\begin{array}{r}20 \\
3 \\
1 \\
15\end{array}$ & $\begin{array}{r}10 \\
9 \\
2\end{array}$ & $\begin{array}{r}12 \\
5\end{array}$ & $\begin{array}{r}14 \\
9\end{array}$ \\
\hline $\begin{array}{l}\text { Thalassiosira fraga } \\
T . \text { leptopus } \\
T . \text { umaoiensis } \mathrm{n} . \mathrm{sp} \text {. } \\
\text { Thalassiothrix longissima } \\
\text { Triceratium condecorum }\end{array}$ & - & - & & : & $\dot{*}^{1}$ & $\cdot \overrightarrow{1}$ & $\begin{array}{l}\cdot \\
\cdot\end{array}$ & 14 & 2 \\
\hline Miscellaneous & 2 & & & 1 & & & 6 & & \\
\hline \multicolumn{10}{|l|}{ Nonmarine diatoms } \\
\hline $\begin{array}{l}\text { Aulacosira granulata s.1. } \\
\text { A. sp. } 1 \\
\text { Miscellaneous }\end{array}$ & - & 4 & 3 & 7 & $\begin{array}{l}3 \\
\cdot\end{array}$ & & 21 & $\begin{array}{r}36 \\
1 \\
2\end{array}$ & 31 \\
\hline Total number of diatom valves counted & 100 & 100 & 100 & 100 & 100 & 100 & 100 & 100 & 100 \\
\hline Resting spores of Chaetoceros & 22 & 26 & 57 & 61 & 33 & 28 & 37 & 33 & 42 \\
\hline
\end{tabular}

Note: Numbers represent individuals in routine 100 count; ${ }^{*}$ indicates presence of taxa. See Figure 2 for complete names of diatom zones. 
Table 11. Stratigraphic occurrence of diatoms in Hole 183, Leg 19.

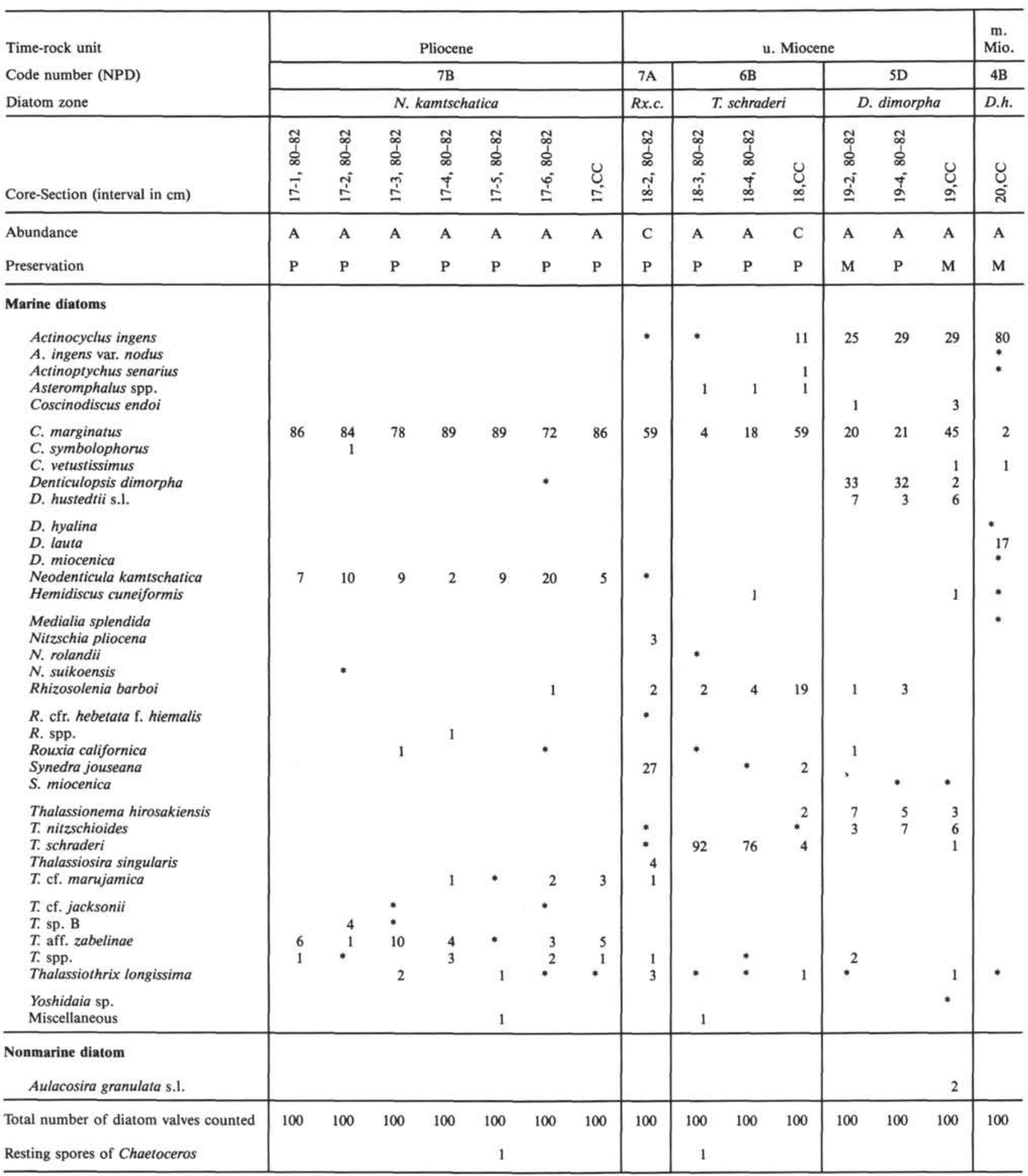

Note: Numbers represent individuals in routine 100 count; * indicates presence of taxa. See Figure 2 for complete names of diatom zones.

deri, almost monospecific assemblages, resulting from strong dissolution of diatoms. Most valves of T. schraderi in this zone lack their mantles. A. ingens occurs commonly to abundantly from $183-18$, CC through 18320, CC. The Denticulopsis katayamae Zone (NPD6A) is either missing in this hole or represented by an interme- diate horizon between 183-18,CC and 183-19-2, 80-82 $\mathrm{cm}$, because no intermediate samples were available. An interval from $183-19-2,80-82 \mathrm{~cm}$ to $183-19, \mathrm{CC}$ is assigned to the $D$. dimorpha Zone (NPD5D), based on a limited and abundant occurrence of $D$. dimorpha. Sample $183-20, C C$, which is characterized by a mass occur- 
rences of $A$. ingens, belongs to the $D$. hyalina Zone (NPD4B), based on the co-occurrence of $D$. hyalina and $D$. lauta and the absence of $D$. hustedtii.

All the Site 192 samples examined also contain diatoms in varying abundance and states of preservation (Table 12). In general, this hole contains fewer diatom remains than Hole 183, but their preservation is far better. Samples 192-21-1, 50-52 cm and 192-21,CC belong to the N. kamtschatica Zone (NPD7B). Abundant $N$. kamtschatica and rare, but limited, occurrences of Thalassiosira aff. zabelinae characterize the zone. Samples from 192-22-1, 100-102 cm through 192-23,CC are assigned to the $R$. californica Zone (NPD7A), the top of which is marked by the last occurrence of $R$. californica rather than its last abundant occurrence, as in Holes 584 and 438A. Thalassiosira singularis is limited to this zone and is a good marker for it in this hole. Sample 192-24-2, 20-22 cm belongs to the Thalassionema schraderi Zone (NPD6B), where the species occurs en masse, although it becomes less frequent in lower horizons. The interval represented by Samples 192-24,CC and 192-25-1, 80-82 $\mathrm{cm}$ is assigned to the D. katayamae Zone (NPD6A), which is characterized by common to abundant $D$. katayamae without $D$. dimorpha. A rare occurrence of $D$. dimorpha in this zone is attributed to reworking. Sample 192-25,CC belongs to the $D$. dimorpha Zone (NPD5D), based on a limited occurrence of the species. Samples 192-26-1, 108-110 cm and 192-26,CC belong to the Thalassiosira yabei Zone (NPD5C), defined as the interval between the last occurrence of $D$. praedimorpha and the first occurrence of $D$. dimorpha. No $D$. lauta was observed in any sample from Hole 192.

As shown above, the diatom middle-latitude zonal framework used for Sites 438 and 584 of the North Pacific can be successfully applied to both Sites 183 and 192 from high latitudes off the Aleutians.

\section{MODIFIED NEOGENE DIATOM ZONATION OF THE MIDDLE-TO-HIGH LATITUDE OF THE NORTH PACIFIC}

Among the 19 diatom zones described below, three (the lower Miocene Thalassiosira spinosa Zone and the Pliocene Neodenticula koizumii-N. kamtschatica and $N$. koizumii zones) were not recognized in the materials described in this chapter, but they are included here to complete the total framework of the middle-to-high latitude, North Pacific Neogene diatom zonation (Fig. 7).

\section{Thalassiosira spinosa Zone (NPD1) (tentative)} a).

Author. Schrader (1976); modified by Barron (in press

Category. Partial-Range Zone.

Definition. The base and the top are defined by the first occurrences of Thalassiosira spinosa and T. fraga, respectively.

Age. early early Miocene, $\sim 23-19.5 \mathrm{Ma}$ (Barron, in press a).

Remarks. The presence of this zone is suggested in samples dredged from the Bering Sea (Barron, in press a), but this lowermost Miocene zone is not recognized in the materials discussed in this chapter, nor is its pres- ence confirmed in any on-land sequence from Japan. The lower B Subzone of the Kisseleviella carina Zone (Akiba and Ichinoseki, 1983) from the lower part of the Tokomuro Formation in the Atsunai Area, eastern Hokkaido, however, might belong either to this zone or might range down to upper Oligocene. Another possible location of this zone is suggested in some horizons of the Hota Group, Boso Peninsula, central Japan, because a possible Oligocene diatom flora and diatom species indicative of the Thalassiosira fraga Zone overlying the $T$. spinosa Zone have been recognized in that group (Akiba, unpublished data).

\section{Thalassiosira fraga Zone (NPD2)}

Author. Schrader and Fenner (1976); modified by Barron (in press a).

Category. Partial-Range Zone.

Definition. The base is defined by the first occurrence of $T$. fraga, and the top by a horizon just below the first occurrence of Actinocyclus ingens.

Characteristic flora. Assemblages are characterized by such species as Coscinodiscus symbolophorus, C. praenodulifer, Hemiaulus bipons, Ikebea tenuis, Kisseleviella carina, K. ezoensis n. sp., Pseudotriceratium chenevieri, Rhizosolenia $\mathrm{cf}$. hebetata f. hiemalis, Synedra jouseana s.l., and Thalassiosira fraga. Both Actinocyclus ingens and Thalassionema nitzschioides, abundant in higher horizons, are characteristically absent.

Age. early early Miocene, $19.5-\sim 16.8 \mathrm{Ma}$ (Barron, in press a).

Correlation with other diatom zones. This zone is correlative with the upper part of the Kisseleviella carina Zone of Koizumi (1979) and with the upper A Subzone of the $K$. carina Zone of Akiba and Ichinoseki (1983).

Remarks. Koizumi's (1979) $K$. carina Zone is defined by a horizon below the first occurrence of Actinocyclus ingens and is characterized by common to abundant occurrence of $K$. carina, but its base is not defined yet. My preference for the Thalassiosira fraga Zone instead of the $K$. carina Zone is primarily because the genus Kisseleviella is presumably neritic and has a less extensive geographic distribution and less constant occurrence than those of T. fraga. More taxonomic studies of Kisseleviella species should be done before using them biostratigraphically (although we have introduced here a new stratigraphically useful species, $K$. ezoensis $\mathrm{n}$. sp., which is restricted to this zone).

This zone, present offshore only in Hole 439, is distributed widely in the Atsunai Area, eastern Hokkaido (Akiba and Ichinoseki, 1983), and in an isolated finding in the Hota Group of Bōsō Peninsula, central Japan (Akiba, 1980, unpublished data). The Kisseleviella carina Zone of Koizumi (1979) recognized mainly in the Joban Area of northeastern Honshu (Tsuchi et al., 1981a) may correspond either to this zone or to the underlying T. spinosa Zone.

\section{Crucidenticula kanayae Zone (NPD3A)}

Author. New zone, this chapter.

Category. Interval Zone.

Definition. The base is defined by the first occurrence of Actinocyclus ingens, and the top by a horizon just 
Table 12. Stratigraphic occurrence of diatoms in Hole 192, Leg 19.

\begin{tabular}{|c|c|c|c|c|c|c|c|c|c|c|c|c|}
\hline \multirow{3}{*}{$\begin{array}{l}\text { Time-rock unit } \\
\text { Code number (NPD) } \\
\text { Diatom zone }\end{array}$} & \multirow{2}{*}{\multicolumn{2}{|c|}{$\begin{array}{l}\text { PI. } \\
7 \mathrm{~B}\end{array}$}} & \multicolumn{10}{|c|}{ u. Miocene } \\
\hline & & & & 7 & A & & $6 \mathrm{~B}$ & 6 & A & SD & & C \\
\hline & \multicolumn{2}{|c|}{ N.k. } & \multicolumn{4}{|c|}{ R. californica } & T.s. & \multicolumn{2}{|c|}{ D.k. } & D.d. & \multicolumn{2}{|c|}{ T.y. } \\
\hline Core-Section (interval in $\mathrm{cm}$ ) & 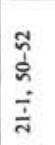 & $\frac{\dot{U}}{\text { n }}$ & 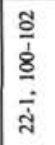 & Uี & $\frac{\frac{\pi}{1}}{\frac{\pi}{2}}$ & प्र & 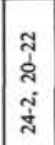 & 岂 & $\begin{array}{l}\text { क } \\
\vdots \\
\vdots \\
\text { ¿ें }\end{array}$ & 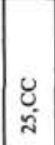 & $\begin{array}{l}\frac{0}{1} \\
0 \\
\frac{1}{6} \\
\frac{1}{6}\end{array}$ & U్ \\
\hline Abundance & A & C & $\mathrm{C}$ & C & $\mathrm{C}$ & C & $\mathrm{C}$ & A & A & $\mathrm{C}$ & $\mathbf{R}$ & $\mathbf{R}$ \\
\hline Preservation & M & M & $\mathrm{P}$ & $\mathrm{M}$ & M & $\mathbf{P}$ & $\mathbf{P}$ & G & M & $\mathbf{P}$ & $\mathbf{P}$ & $\mathbf{P}$ \\
\hline \multicolumn{13}{|l|}{ Marine diatoms } \\
\hline $\begin{array}{l}\text { Actinocyclus ingens } \\
\text { A. octonarius } \\
\text { Actinoptychus senarius } \\
\text { Asteromphatus spp. } \\
\text { Cocconeis antiqua }\end{array}$ & 1 & $\cdot$ & $\begin{array}{l}1 \\
9\end{array}$ & $\begin{array}{l}1 \\
4\end{array}$ & 4 &.$^{6}$ & $\begin{array}{l}6 \\
1 \\
1\end{array}$ & . & : & 2 & $\begin{array}{r}23 \\
1\end{array}$ & $\begin{array}{r}55 \\
2\end{array}$ \\
\hline $\begin{array}{l}\text { C. californica } \\
\text { C. costata } \\
\text { C. scutellum } \\
\text { Coscinodiscus endoi }\end{array}$ & $\begin{array}{l}1 \\
3 \\
1\end{array}$ & $\begin{array}{l}2 \\
1 \\
\cdot\end{array}$ & • & 15 & $*^{2}$ & 1 & 10 & - & $\dot{1}_{1}$ & $\begin{array}{r}2 \\
19\end{array}$ & 1 & * \\
\hline $\begin{array}{l}\text { C. oculus-iridis } \\
\text { C. symbolophorus } \\
\text { Cosmiodiscus insignis } \\
\text { Cymatosira debyi } \\
\text { Denticulopsis dimorpha }\end{array}$ & $\begin{array}{l}\cdot \\
1 \\
\cdot\end{array}$ & - & $\begin{array}{l}3 \\
2\end{array}$ & $\begin{array}{l}2 \\
1\end{array}$ & + & $\begin{array}{l}2 \\
1\end{array}$ & & & . & 10 & 1 & \\
\hline $\begin{array}{l}\text { D. hustedtii s.l. } \\
\text { (D. katayamae })^{\text {a }} \\
\text { Neodenticula kamtschatica } \\
\text { Hemidiscus cuneiformis } \\
\text { Hyalodiscus obsoletus }\end{array}$ & $\begin{array}{l}39 \\
\cdot\end{array}$ & & 2 & $\begin{array}{l}1 \\
1 \\
1\end{array}$ & 1 &.$^{1}$ & & $\begin{array}{r}41 \\
2\end{array}$ & $\begin{array}{r}49 \\
30 \\
.\end{array}$ & 39 & 20 & $\begin{array}{l}1 \\
1\end{array}$ \\
\hline $\begin{array}{l}\text { Ikebea tenuis } \\
\text { Kisseleviella carina } \\
\text { Melosina sol } \\
\text { Neobrunia mirabilis } \\
\text { Nitzschia rolandii }\end{array}$ & $\dot{1}^{\cdot}$ & 1. & 1 & $\cdot 3$ & 2 & s & $\begin{array}{l}3 \\
\cdot \\
3\end{array}$ & $\begin{array}{l}3 \\
1 \\
\vdots\end{array}$ & & - &.$^{1}$ & 2 \\
\hline $\begin{array}{l}\text { N. suikoensis } \\
N \text {. sp. } 1 \\
N \text {. heteropolica } \\
\text { Odontella aurita } \\
\text { Paralia sulcata }\end{array}$ & $\begin{array}{l}1 \\
2\end{array}$ & 1 & $\begin{array}{l}2 \\
1\end{array}$ & 1 & $\begin{array}{l}2 \\
1\end{array}$ & • & & & 1 & 1 & & • \\
\hline $\begin{array}{l}\text { Rhizosolenia barboi } \\
R \text {. cf. hebetata f. hiemalis } \\
R \text {. sp. } \\
\text { Rouxia californica } \\
R \text {. peragalli }\end{array}$ & $\begin{array}{l}2 \\
3\end{array}$ & $\begin{array}{l}1 \\
1\end{array}$ & - & $\begin{array}{l}4 \\
1\end{array}$ &.$^{4}$ & $\begin{array}{l}3 \\
1\end{array}$ & $\begin{array}{l}2 \\
1\end{array}$ & $\cdot 5$ & - & $\ddot{*}$ & $\begin{array}{l}2 \\
1\end{array}$ & \\
\hline $\begin{array}{l}\text { Stephanopyxis spp. } \\
\text { Synedra jouseana } \\
\text { S. miocenica } \\
\text { Thalassionema hirosakiensis } \\
\text { T. nitschioides }\end{array}$ & 2 & 24 & 12 & $\begin{array}{l}5 \\
9\end{array}$ & $\begin{array}{l}1 \\
. \\
31\end{array}$ & 4 & 4 & $\begin{array}{r}\cdot \\
1 \\
3 \\
2\end{array}$ & $\begin{array}{l}1 \\
1 \\
1\end{array}$ & $\begin{array}{r}2 \\
13 \\
5\end{array}$ & 6 & $\begin{array}{l}2 \\
+ \\
3 \\
6\end{array}$ \\
\hline $\begin{array}{l}\text { T. schraderi } \\
\text { Thalassiosina antiqua } \\
\text { T. marujamica } \\
\text { T. cf. marujamica } \\
\text { T. manifesta }\end{array}$ & & $\begin{array}{r}\cdot \\
2 \\
\cdot\end{array}$ & $\begin{array}{l}1 \\
1 \\
8 \\
2\end{array}$ & $\begin{array}{l}1 \\
-3 \\
3\end{array}$ & $\begin{array}{l}2 \\
5 \\
1\end{array}$ & • & 58 & & 2 & 1 & & \\
\hline $\begin{array}{l}\text { T. nidulus } \\
\text { T. jacksonii } \\
\text { T. cf. praeconvexa } \\
\text { T. singularis } \\
\text { T. temperei }\end{array}$ & • & & • & 1 & 3 & 4 & 1 & 6 & & & & \\
\hline $\begin{array}{l}T . \text { aff. zabelinae } \\
T . \text { sp. B } \\
T \text {. spp. } \\
\text { Thalassiothrix longissima } \\
\text { Triceratium condecorum }\end{array}$ & $\cdot$ & $?^{1}$ & i0 & $\begin{array}{r}10 \\
1\end{array}$ & $\begin{array}{r}13 \\
4\end{array}$ & $\begin{array}{l}2 \\
1\end{array}$ & $\begin{array}{l}1 \\
1\end{array}$ & $\begin{array}{l}3 \\
. \\
-\end{array}$ & . & . & & \\
\hline Miscellaneous & 2 & 3 & 5 & 6 & 2 & 7 & 5 & 3 & & & 3 & 3 \\
\hline $\begin{array}{l}\text { Nonmarine diatom } \\
\text { Aulacosira granulata }\end{array}$ & & & 1 & & & & & $\cdot$ & & • & & \\
\hline Total number of diatom valves counted & 100 & 100 & 100 & 100 & 100 & 100 & 100 & 100 & 100 & 100 & 100 & 100 \\
\hline Resting spores of Chaetoceros & 83 & 22 & 24 & 47 & 41 & 20 & 9 & 7 & 3 & 5 & 49 & 22 \\
\hline
\end{tabular}

Note: Numbers represent individuals in routine 100 count; $\bullet$ indicates presence of taxa. See Figure 2 for complete names of diatom zones.

${ }^{a} D$. katayamae counted twice: in D. katayamae and in D. hustedtii s.l. Number of D. katayamae here is that included in $D$. hustedtii s.1. 


\begin{tabular}{|c|c|c|c|c|c|c|c|c|c|c|}
\hline & & & & $\begin{array}{l}\text { This report } \\
\text { (Leg 87) }\end{array}$ & $\begin{array}{l}\text { Code } \\
\text { number } \\
\text { (NPD) }\end{array}$ & Barron, in & & $\begin{array}{l}\text { s a; } \\
\text { anum } \\
\text { UNPD }\end{array}$ & ron, $1980 \mathrm{a}$ & \\
\hline & & & & Neodenticula seminae & 12 & D. seminae & & 12 & D. seminae & \\
\hline & $\begin{array}{l}\text { Akiba, } 1982 \\
\text { Akiba et al }\end{array}$ & & & Rhizosolenia curvirostris & 11 & R. curvirostris & $\begin{array}{l}\mathrm{b} \\
\mathrm{a}\end{array}$ & 11 & R. c. & $\frac{b}{a}$ \\
\hline & $\begin{array}{c}1982 \\
\text { ba \& Ichlnosek }\end{array}$ & eki, 19 & & Actinocyclus oculatus & 10 & A. oculatus & & 10 & A. oculatus & \\
\hline $\begin{array}{c}\text { Akiba, } \\
1977,1979\end{array}$ & D. seminae v & var. & & Neodenticula koizumii & 9 & D. seminae v, fossili & & 9 & D. s. v. f. - D. $k$. & \\
\hline D.s. -D.k. & D.s.v. $-D . k m$ & & $\begin{array}{c}\text { Maruyama, } \\
1984\end{array}$ & N. koizumi-N. kamtschatica & 8 & D. s. v. f. $-D . k$. & & 8 & D. s. v. f. $-D$. k. & \\
\hline D. kamtschatica & & A & & Neodenticula kamtschatica & $7 \mathrm{~B}$ & & $\frac{c}{b}$ & & & $\frac{c}{b}$ \\
\hline & D. kmt. & & D. katayamae & & $7 \mathrm{~A}$ & D. kamtschatica & a & 7 & D. $k$. & a \\
\hline $\begin{array}{c}\text { Coscinodiscus } \\
\text { marginatus }\end{array}$ & T. schrade & & T. schraderi & Thalassionema schraderi & $6 \mathrm{~B}$ & & b & 6 & 0 & b \\
\hline & & A & D. katayamae & Denticulopsis katayamae & $6 \mathrm{~A}$ & D. musteati & a & 0 & U. $n$ & a \\
\hline D. h. & D. hustedtii & D. $d$. & D. dimorpha & Denticulopsis dimorpha & $5 \mathrm{D}$ & & d & & & d \\
\hline C. $y$. & & C. $y$. & $\begin{array}{c}\text { Coscinodiscus } \\
\text { yabei }\end{array}$ & Thalassiosira yabei & $5 C$ & D. hustedtii- & c & 5 & & c \\
\hline D. praedimorpha & D. p. & & D. $p$. & Denticulopsis praedimorpha & $5 B$ & 0 loute & b & 3 & D. h. D. I. & b \\
\hline D. nicobarica & D. nicobaric & rica & D. nicobarica & Crucidenticula nicobarica & $5 \mathrm{~A}$ & & a & & & \\
\hline & & A & $\frac{\text { D. hustedtii }}{\text { D. hyalina }}$ & Denticulopsis hyalina & 4B & & b & & & $\mathrm{b}$ \\
\hline D. lauta & D. lauta & B & D. lauta & Denticulopsis lauta & $4 \mathrm{~A}$ & D. lauta & a & 4 & D. $I$. & a \\
\hline D kanayae & A ingens & A & A. ingens & Denticulopsis praelauta & $3 B$ & Actinocyclus & & 3 & A. ingens & a \\
\hline & & B & & Crucidenticula kanayae & $3 \mathrm{~A}$ & ingens & & 3 & & \\
\hline & & A & & Thalassiosira fraga & 2 & T. fraga & & 2 & & \\
\hline & ^. camma & B & & Thalassiosira spinosa & 1 & T. spinosa & & 1 & & \\
\hline
\end{tabular}

Figure 7. Correlation of various diatom zonal subdivisions in the middle-to-high latitudes of the North Pacific.

below the first occurrence of Denticulopsis praelauta $\mathrm{n}$. sp.

Characteristic flora. The lower part of this zone is characterized by abundant to mass occurrence of $C$. $k a$ nayae and the upper part by its rare occurrence. Other characteristic diatom species include Actinocyclus ingens, Coscinodiscus praenodulifer, C. symbolophorus, Crucidenticula ikebei, Denticula norwegica, Ikebea tenuis, Kisseleviella carina, Medialia splendida, and Synedra jouseana s.l.

Age. late early Miocene, 16.6-16.4 Ma (Barron, in press $\mathrm{a}$, and estimate of this chapter).

Correlation with other diatom zones. This new zone is correlative with the lower part of the Actinocyclus ingens Zone of Barron (1980a) and the lower B Subzone of the A. ingens Zone of Akiba and Ichinoseki (1983).

Remarks. The first occurrences of $C$. kanayae and Thalassionema nitzschioides as well as Actinocyclus ingens, seem to coincide with the base of this zone. The synchrony of first occurrences of these three species is, however, dubious because continuity from the underlying Thalassiosira fraga Zone to this zone is not yet established. Although these two zones occur both in Hole
439 and in the previously mentioned Atsunai Area of eastern Hokkaido, they are bounded by unconformities (Akiba and Ichinoseki, 1983; this chapter). Thalassionema nitzschioides constitutes one of the dominant elements of diatom assemblages starting from this zone and continuing through all younger zones, and therefore is not biostratigraphically characteristic of any of the younger zones.

\section{Denticulopsis praelauta Zone (NPD3B)}

Author. New zone, this chapter.

Category. Partial-Range Zone.

Definition. The base is defined by the first occurrence of $D$. praelauta $\mathrm{n}$. sp., and the top by a horizon just below the first occurrence of Denticulopsis lauta.

Characteristic flora. Assemblages of this zone are very similar to those of the underlying Crucidenticula kanayae Zone, but are easily distinguished by the presence of D. praelauta.

Age. late early Miocene, $\sim 16.4-15.9 \mathrm{Ma}$ (estimate of this chapter; Barron, in press a).

Correlation with other diatom zones. This new zone is correlative with the upper part of the Actinocyclus in- 


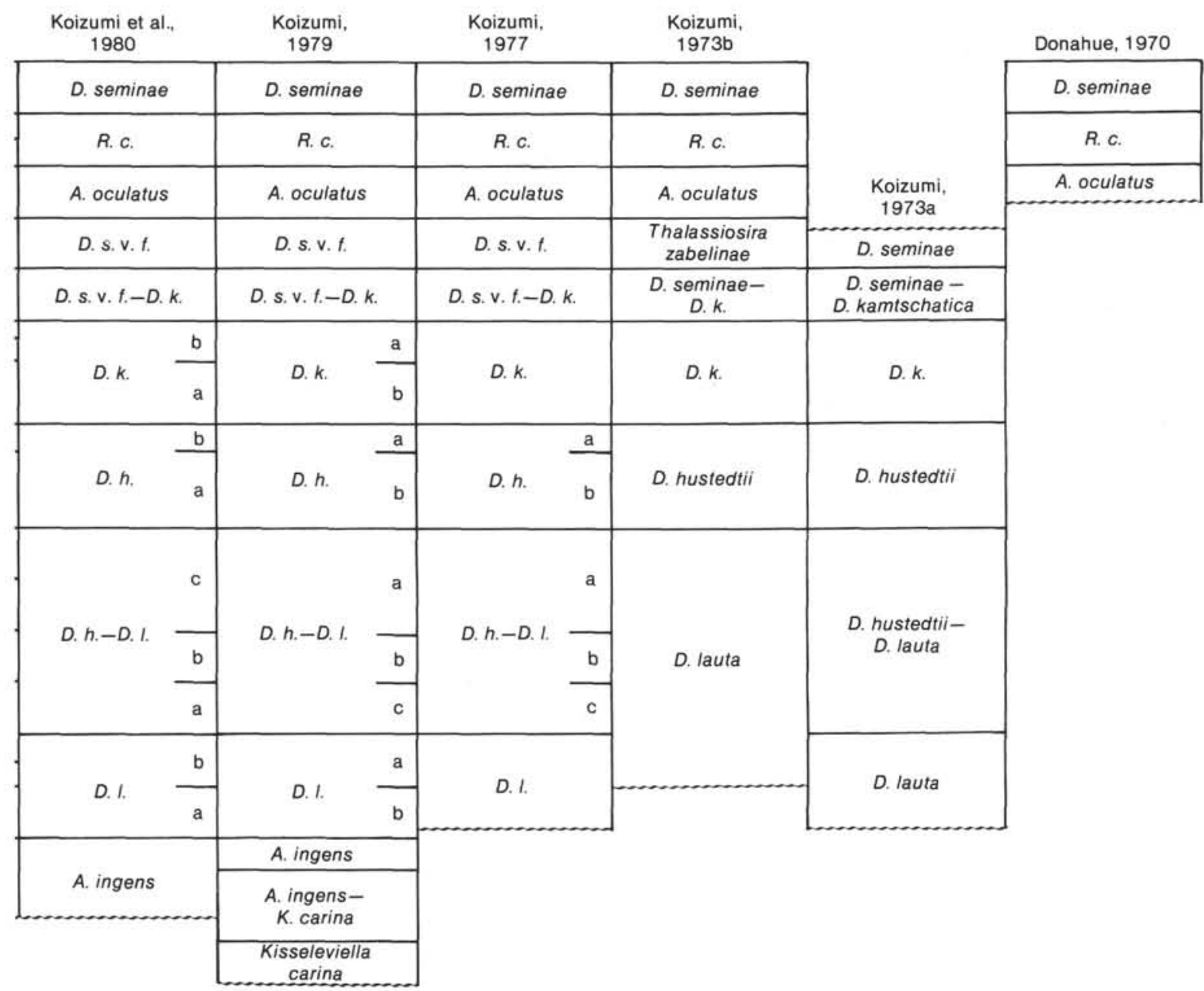

Figure 7. (Continued).

gens Zone of Barron (1980a), the A. ingens Zone of Akiba and others (1982), and the upper A Subzone of $A$. ingens Zone of Akiba and Ichinoseki (1983). The lower part of this zone and all of the Crucidenticula kanayae Zone recognized in Hole 439 could be correlated to Koizumi's (1979) Actinocyclus ingens-Kisseleviella carina Zone.

Remarks. The Actinocyclus ingens Zone of Barron (1980a) includes both this zone and the underlying $C$. kanayae Zone, but they are easily distinguished in his occurrence charts because he recorded Denticulopsis praelauta n. sp. as Denticula cf. lauta. The Actinocyclus ingens-Kisseleviella carina Zone of Koizumi (1979) is defined as the interval between the first occurrence of $A$. ingens and the last common to abundant occurrence of $K$. carina. The biostratigraphic usefulness of the latter datum is doubtful because of its limited geographic extent and because the relative frequencies of $K$. carina fluctuate considerably (Akiba et al., 1982).

\section{Denticulopsis lauta Zone (NPD4A)}

Author. Koizumi (1973a) and Barron (1980a); modified by Maruyama (1984) and this chapter.
Category. Partial-Range Zone.

Definition. The base is defined by the first occurrence of $D$. lauta, and the top by a horizon just below the first occurrence of Denticulopsis hyalina.

Characteristic flora. D. lauta consistently dominates assemblages of this zone. Other characteristic flora include Actinocyclus ingens, $A$. ingens var. nodus, Coscinodiscus symbolophorus, Ikebea tenuis, Kisseleviella carina, Medialia splendida, Nitzschia challengeri, Rouxia naviculoides, and Trochosira spinosa.

Age. early middle Miocene, 15.9-14.9 Ma (Barron, $1980 \mathrm{a}$, in press a).

Correlation with other diatom zones. This zone is correlative with the lower part of the D. lauta Zone of Koizumi (1973a), the lower $a$ Subzone of the $D$. lauta Zone of Barron (1980a), and the lower $B$ Subzone of the $D$. lauta Zone of Akiba and Ichinoseki (1983).

Remarks. The base of this zone closely approximates the lower Miocene/middle Miocene boundary (Barron, 1980a). The base of the D. lauta Zone, recognized in the Kadonosawa Formation, Ninohe Area, northeastern Honshu (Maruyama, 1984) is suspect, because I have identified $D$. praelauta instead of $D$. lauta in that formation. 
Denticulopsis hyalina Zone (NPD4B)

Author. Maruyama (1984); modified in this chapter. Category. Partial-Range Zone.

Definition. The base is defined by the first occurrence of $D$. hyalina, and the top by a horizon just below the first common occurrence of $D$. hustedtii.

Characteristic flora. Common to abundant occurrences of both Denticulopsis hyalina and D. lauta characterize the lower part of this zone. Assemblages from the upper part of this zone are represented almost exclusively by $D$. hyalina; and those in the lower part are very similar to those of the D. lauta Zone.

Age. early middle Miocene, 14.9-13.9 Ma (Barron, $1980 \mathrm{a}$, in press a).

Correlation with other diatom zones. This zone is correlative with the upper part of the $D$. lauta Zone of Koizumi (1973b), the upper $b$ Subzone of the D. lauta Zone and the lower part of the $a$ Subzone of the D. hustedtii$D$. lauta Zone of Barron (1980a). It is identical to the upper $b$ Subzone of the $D$. lauta Zone of Barron (1981, in press a), and to the upper $A$ Subzone of the $D$. lauta Zone of Akiba and Ichinoseki (1983).

Remarks. This zone includes two zones proposed by Maruyama (1984), namely his $D$. hyalina Zone and the overlying $D$. hustedtii Zone, distinguished by rare occurrences of $D$. hustedtii in the latter, according to Maruyama. I believe, however, that his $D$. hustedtii Zone is not operational and has a narrow geographic application. D. hustedtii is so rare and occurrences so sporadic in the upper part of the $D$. hyalina Zone, as it is defined in this chapter, that the zone is difficult to recognize. Also, the first rare occurrence of $D$. hustedtii is diachronous in the North Pacific, but the first common to abundant occurrence of the species in the middle-to-high latitude areas appears to be isochronous (Barron, 1981; Barron and Keller, 1983).

\section{Crucidenticula nicobarica Zone (NPD5A)}

Author. Akiba and others (1982).

Category. Interval Zone.

Definition. The base is defined by the first common occurrence of Denticulopsis hustedtii, and the top by a horizon just below the first occurrence of $D$. praedimorpha.

Characteristic flora. Assemblages of this zone are dominated by $D$. hustedtii and characterized by rare to common occurrence of $C$. nicobarica.

Age. late middle Miocene, 13.9-13.3 Ma (Barron, $1980 \mathrm{a}, 1981$, in press a).

Correlation with other diatom zones. This zone is correlative with the upper part of the lowermost $a$ Subzone of the Denticula hustedtii-D. lauta Zone of Barron (1980a) and is identical to the same subzone of the $D$. hustedtii-D. lauta Zone of Barron (1981, in press a) and to the Denticulopsis nicobarica Zone of Maruyama (1984).

Remarks. A Denticulopsis hyalina abundance decrease and $D$. hustedtii increase at the base of this zone are attributed to an "evolutional transition of $D$. hyalina to D. hustedtii" (Barron, in press a). Both the morphologic characteristics and stratigraphic occurrences of $D$. lauta, $D$. hyalina, and $D$. hustedtii, however, indicate that $D$. hustedtii evolved from $D$. lauta in the upper part of the underlying $D$. hyalina Zone (Maruyama, 1984; Akiba and Yanagisawa, this volume). Correlation of this zone with the zonations of Koizumi (1973a,b; 1977; 1979) is difficult because Koizumi did not recognize D. praedimorpha, whose first occurrence marks the top of this zone. Common occurrence of $C$. nicobarica is restricted to this zone, although the last rare occurrence of this species is recognized in the lower part of the overlying $D$. praedimorpha Zone. D. lauta last occurs in the lower part of this zone.

\section{Denticulopsis praedimorpha Zone (NPD5B)}

Author. Akiba and others (1982).

Category. Total-Range Zone.

Definition. This zone is represented by the total range of D. praedimorpha.

Characteristic flora. Assemblages of this zone are dominated by both Denticulopsis hustedtii and D. praedimorpha and characterized by Nitzschia umaoiensis $\mathrm{n}$. sp., Rhizosolenia praebarboi, and Thalassiosira praenidulus $\mathrm{n}$. sp., among others.

Age. late middle Miocene, 13.3-12.1 Ma (Barron, 1980a, 1981; paleomagnetic calibration in this chapter).

Correlation with other diatom zones. This zone is nearly correlative with the $b$ Subzone of the Denticulopsis hustedtii-D. lauta Zone of Barron (1980a, 1981, in press a) and with the lower part of Coscinodiscus yabei assemblage of Kanaya (1959).

Remarks. Kanaya (1959) clearly used the Coscinodiscus yabei assemblage as a biostratigraphic zone. Such a zone would also include the overlying Thalassiosira yabei Zone, which can be easily distinguished in his occurrence charts because he recorded some of the valve elements of $D$. praedimorpha (morphologically unique intercalary bands of the species) as Denticula ? sp.

No definite correlation of this zone with the zonation of Koizumi (1973a, b; 1975c; 1977; 1979) is possible, except that NPD5B represents a part of his D. hustedtiiD. lauta Zone, defined by Koizumi as an interval of overlapping ranges of $D$. hustedtii and $D$. lauta. Akiba and others (1982) claimed, however, that the two species do not co-occur in general, but that species which have been recognized commonly in association with $D$. hustedtii are either $D$. praedimorpha or $D$. dimorpha, which are close to, but clearly separated from, D. lauta. Accordingly, they proposed several new diatom zones to replace the $D$. hustedtii-D. lauta Zone.

Barron (1980a, 1981, in press a) also used the name $D$. hustedtii-D. lauta Zone, although datums used to subdivide the zone more closely resemble those used in this chapter than those of Koizumi (1975c, 1977, 1979). Barron (1980a, 1981, in press a) incorporated both $D$. praedimorpha and $D$. dimorpha in his zonation, but it is probable that he identified part of valves of these two species as Denticulopsis lauta. Evidence of such an identification is that listed frequencies of both $D$. dimorpha and $D$. praedimorpha are proportional to those of $D$. lauta (Barron and Keller, 1983). Morphologic distinctions among $D$. lauta, $D$. praedimorpha, and $D$. dimor- 
pha were presented by Akiba (1982b) and Maruyama (1984), and more detailed discussions based on scanning electronmicroscopic observations are given in Akiba and Yanagisawa (this volume). Barron (1980a) used the first occurrence of Rhizosolenia barboi to define the top of his $b$ Subzone of the $D$. hustedtii-D. lauta Zone, which is nearly correlative with the $D$. praedimorpha Zone of this chapter. Unfortunately, $R$. barboi is rare, and distinction between it and its ancestor, $R$. praebarboi, is sometimes difficult. Consequently, the last occurrence of $D$. praedimorpha, which is close to the first occurrence of $R$. barboi, is a preferred datum for zonal subdivisions.

\section{Thalassiosira yabei Zone (NPD5C)}

Author. Maruyama (1984).

Category. Interval Zone.

Definition. The base is defined by a horizon just above the last occurrence of Denticulopsis praedimorpha, and the top by a horizon just below the first occurrence of D. dimorpha.

Characteristic flora. Assemblages of this zone are dominated by Denticulopsis hustedtii and by rare to frequent occurrences of Thalassiosira yabei.

Age. early late Miocene, 12.1-11.3 Ma (Barron, 1980a, 1981 , in press a; paleomagnetic calibration of this chapter).

Correlation with other diatom zones. This zone is identical to the Coscinodiscus yabei Subzone of the Denticulopsis hustedtii Zone (Akiba et al., 1982), and also to the $c$ Subzone of the D. hustedtii-D. lauta Zone (Barron, 1980a). The Coscinodiscus yabei assemblage (Kanaya, 1959) nearly corresponds to this zone, although it also evidently includes the underlying Denticulopsis praedimorpha Zone, as mentioned before.

Remarks. Correlation of this zone with Koizumi's zonation $(1973 a, b ; 1977 ; 1979)$ is difficult, primarily because he has not distinguished Denticulopsis praedimorpha either from $D$. dimorpha or from $D$. lauta. This zone may be correlative with some horizon either within his $D$. hustedtii- $D$. lauta Zone or within the lower $b$ Subzone of the D. hustedtii Zone of Koizumi (1977). For example, the T. yabei Zone, recognized in Hole 192 in this chapter, is included in the $D$. hustedtii-D. lauta Zone of Koizumi (1973b, 1977). The lower part of the $D$. hustedtii Zone, in the on-land sequence of the Oga Peninsula, northeast Japan (Koizumi, 1977), however, belongs to the $T$. yabei Zone, because $D$. lauta, which Koizumi (1977) identified as occurring in the lower horizon of the sequence, is really $D$. praedimorpha, which is also listed in Kanaya's (1969) occurrence chart of the sequence. Conversely, Koizumi's (1977) lower $b$ Subzone of the $D$. hustedtii Zone could represent either this zone or the Denticulopsis katayamae Zone (NPD6A).

Assemblages of this zone superficially resemble those of the D. katayamae Zone; both assemblages are dominated by $D$. hustedtii s.l., and the occurrence of $T$. yabei is not always consistent in this zone. Accordingly, Akiba and others (1982) pointed out a difficulty in separating the two zones when only spot samples are studied. Ex- amination with higher magnification indicates, however, that two zones are easily distinguished, because $D$. hustedtii s.l. in the $D$. katayamae Zone is represented mostly by $D$. katayamae, but $D$. hustedtii s.l. in the T. yabei Zone is totally represented by $D$. hustedtii s.s. as clarified by Maruyama (1984).

Barron (1980a, in press a) placed the middle Miocene/upper Miocene boundary in the middle of his $c$ Subzone of the $D$. hustedtii- $D$. lauta Zone, correlative with the T. yabei Zone of this chapter. Paleomagnetic calibration of diatom zones of Hole 584 suggests that the boundary lies in the lower part of this zone.

\section{Denticulopsis dimorpha Zone (NPD5D)}

Author. Maruyama (1984).

Category. Total-Range Zone.

Definition. This zone is defined by the total range of D. dimorpha.

Characteristic flora. Assemblages of this zone are dominated by both $D$. hustedtii s.l. and $D$. dimorpha.

Age. early late Miocene, 11.3-10.4 Ma (Barron, 1980a, 1981; paleomagnetic calibration of this chapter).

Correlation with other diatom zones. This zone is identical to both the $D$. dimorpha Subzone of the $D$. hustedtii Zone (Akiba et al., 1982) and to the $d$ Subzone of the D. hustedtii-D. lauta Zone (Barron, 1980a).

Remarks. Koizumi (1982) suggested a longer range of D. dimorpha in high-latitude areas than in middle-latitude areas, but my re-examination of Site 183 and 192 samples show no such difference. The first occurrence of Denticulopsis katayamae in the middle of this zone is an important datum. The first common occurrence of Thalassiosira cf. praeconvexa is also recognized at this horizon in Hole 438A.

\section{Denticulopsis katayamae Zone (NPD6A)}

Author. Maruyama (1984); modified in this chapter. Category. Interval Zone.

Definition. The base is defined by a horizon just above the last occurrence of Denticulopsis dimorpha, and the top by a sudden uphole decrease or last common occurrence of D. hustedtii s.l.

Characteristic flora. Assemblages of this zone are dominated by $D$. hustedtii s.l., most of which are $D$. katayamae. Thalassiosira cf. praeconvexa also occurs abundantly in well-preserved assemblages.

Age. late late Miocene, 10.4-9.0 Ma (Barron, 1980a; estimate of this chapter).

Correlation with other diatom zones. This zone is identical to the uppermost A Subzone of the D. hustedtii Zone of Akiba and others (1982), is correlative with the lowermost part of $a$ Subzone of the D. hustedtii Zone of Barron (1980a), and is nearly correlative with the same zone of Maruyama (1984).

Remarks. Maruyama (1984) originally defined the top of this zone by the last occurrence of $D$. katayamae. Because it is difficult to recognize his datum precisely, the zone is modified here as described above. Distinction between $D$. hustedii s.s. and the closely related form, $D$. katayamae, is only possible in valve-views and at high- 
er magnifications. Even so, many specimens showing a girdle view cannot be assigned confidently to either one of the two, but should be left as D. hustedtii s.1.

\section{Thalassionema schraderi Zone (NPD6B)}

Author. Akiba (1982a).

Category. Partial-Range Zone.

Definition. The base is defined by a horizon just above the last common occurrence of Denticulopsis hustedtii s.l., and the top by the last occurrence of $T$. schraderi.

Characteristic flora. Assemblages are characteristically dominated by $T$. schraderi and in most cases also by Coscinodiscus marginatus. Other flora include Actinocyclus ingens, Coscinodiscus symbolophorus, Denticulopsis hyalina, Nitzschia pliocena, N. rolandii, Rhizosolenia barboi, Synedra jouseana, Thalassiosira marujami$c a$, T. nidulus, T. temperei, and T. punctata.

Age. late late Miocene, 9.0-7.4 Ma (estimate of this chapter, including paleomagnetic calibration).

Correlation with other diatom zones. This zone is identical to the Thalassionema hirosakiensis s.l. Zone of Akiba and others (1982), correlative with the middle part of the D. hustedtii Zone of Barron (1980a), and approximately assignable to the same zone of Maruyama (1984). Also, the upper part of the $D$. hustedtii Zone through the lower part of $D$. kamtschatica Zone of Koizumi $(1973 b, 1977)$ is nearly correlative with this zone.

Remarks. Koizumi (1973a, b; 1977) recognized that the last occurrence of Denticulopsis hustedtii and the first occurrence of Neodenticula kamtschatica are coincidental, but Akiba (1982a) found a stratigraphic gap between the two events and proposed that this zone represents the interval lost in the gap.

Barron (1980a) recognized the last occurrence of Thalassiosira yabei (as Coscinodiscus yabei) in the middle of this zone and subdivided his $D$. hustedtii Zone into the $a$ (lower) and $b$ (upper) subzones. T. yabei must be extremely rare, however, because I could not find it in the expected horizons of either Hole 584 or $438 \mathrm{~A}$. Accordingly, its last occurrence may not be a useful datum for biostratigraphic subdivision of this horizon, although Barron (1980a) used the datum for directly correlating both low-latitude and middle-to-high-latitude diatom zonation, and Burckle $(1972,1977)$ used it in his lowlatitude zonation. Similarly, Thalassiosira burckliana, which occurs in very limited intervals in my samples, is recognized by Barron (1980a) in much longer intervals.

T. schraderi is mostly restricted to this zone and occurs commonly to abundantly throughout, although its sporadic occurrence is recognized in the lower zones down to the Denticulopsis dimorpha Zone. The species is heavily silicified, allowing zonal recognition even in very poorly preserved samples, such as those from Hole 183. This same characteristic may also facilitate upward reworking of the species, as possibly exemplified in Hole 584, where the last consistent occurrence of the species marks the top of the zone.

An important and easily discernible datum in this zone is the first occurrence of Nitzschia pliocena in the middle of this zone.

\section{Rouxia californica Zone (NPD7A)}

Author. New zone, this chapter.

Category. Interval Zone.

Definition. The base is defined by a horizon just above the last occurrence of Thalassionema schraderi, and the top by the last common occurrence of Rouxia californica.

Characteristic flora. Assemblages of this zone are very similar to those of the underlying $T$. schraderi Zone, but lack T. schraderi and have rare occurrences of Neodenticula kamtschatica.

Age. latest late Miocene, 7.4-6.0 Ma (Barron, in press a; paleomagnetic calibration of this chapter).

Correlation with other diatom zones. This zone is correlative with the lowermost part of the $a$ Subzone of the Denticula kamtschatica Zone of both Barron (1980a) and Koizumi and others (1980).

Remarks. Neodenticula kamtschatica, which rarely occurs in this zone, is represented by smaller specimens with narrower pseudosepta resembling Nitzschia rolandii to the extent that some specimens are difficult to distinguish. In addition, this zone is recognized in Sado Island in the Japan Sea, despite a complete absence of Neodenticula kamtschatica (Akiba, unpublished data). $N$. kamtschatica suddenly increases uphole near the top of this zone.

The last occurrence of Nitzschia pliocena is in the middle and that of Thalassiosira singularis is near the top of this zone. A characteristic, short acme of Coscinodiscus sp. A is observed in the uppermost part of this zone, useful for approximation of the top of this zone in several localities of Hokkaido (Akiba, 1982a; Akiba and Ichinoseki, 1983). The first occurrence of Thalassiosira antiqua, as recognized in this chapter, coincides with the base of this zone, although Barron (1980a) recognized it in an older horizon, the middle part of the Thalassionema schraderi Zone.

\section{Neodenticula kamtschatica Zone (NPD7B)}

Author. Koizumi (1973a, b); modified in this chapter. Category. Interval Zone.

Definition. The base of this zone is defined by a horizon just above the last common occurrence of Rouxia californica, and the top by a horizon just below the first occurrence of Neodenticula koizumii.

Characteristic flora. Assemblages of this zone are characterized by abundant to mass occurrence of $N$. kamtschatica and numerous Thalassiosira species (Table 6).

Age. latest late Miocene through early Pliocene, 6.03.2 Ma (Barron, 1980a, in press a; paleomagnetic calibration of this chapter).

Correlation with other diatom zones. This zone is correlative with the main part of the same zone of both Koizumi (1973a, b) and Barron (1980a).

Remarks. The last occurrence of Rouxia californica in the lower part of this zone defines the boundary between the lower $a$ Subzone and upper $b$ Subzone of the same zone of Barron (1980a) and Koizumi and others (1980). As previously stated in the biostratigraphy section, the event is also marked by the first occurrence of 
Rossiella tatsunokuchiensis and the last occurrence of Ikebea tenuis ( = Goniothecium tenue) as previously recognized by Barron (1980a). The last occurrence of $R$. californica is discerned with less ease than its last common occurrence, because its fragmented slender valves are easily reworked upward, rendering this distribution of little use for zonal subdivision.

The first occurrence of a low-latitude species, Nitzschia jouseae, is another important event in the lower part of this zone. Barron (1980a) used the last occurrence of Cosmiodiscus insignis to define the middle $b$ Subzone/upper $c$ Subzone boundary within this zone, but the present examination suggests that its occurrence is altogether too sporadic to allow confident identification of its last occurrence.

The first occurrence of Neodenticula koizumii (= Denticula or Denticulopsis seminae var. fossilis), which defines the top of this zone, is dated $4.2 \mathrm{Ma}$ by Burckle and Opdyke (1977) and 3.2 Ma by Barron (1980a), respectively. Barron (1980a) attributed the discrepancy to paleobiogeographic differences; the former and the latter values are representative of high-latitude and middlelatitude first occurrences of the species, respectively. This diachronism might be analogous to that of Denticulopsis hustedtii previously mentioned.

Limited and common occurrence of Delphineis simonsenii in the upper part of this zone, as recognized in Hole 584, will possibly be used to subdivide this zone in on-land sequences of Japan, although its interregional usefulness is unknown because of its possible marine-tychopelagic or shallow-neritic habitat.

\section{Neodenticula koizumii-N. kamtschatica Zone (NPD8)}

Author. Koizumi (1973a, b).

Category. Concurrent-Range Zone.

Definition. The base is defined by the first occurrence of $N$. koizumii, and the top by the last occurrence of $N$. kamtschatica.

Characteristic flora. Assemblages of this zone are dominated by both $N$. kamtschatica and $N$. koizumii.

Age. late Pliocene, 3.2-2.4 Ma (Barron, 1980a).

Remarks. This zone and all of the four remaining younger zones are the same as those documented in detail by Koizumi (1973a, b; 1975c; 1977; 1979), except for some changes of their zonal names bașed on taxonomic changes.

Barron (1980a) used the last common occurrence of $N$. kamtschatica to define the top of this zone, possibly because the species is easily reworked to younger sequences.

\section{Neodenticula koizumii Zone (NPD9)}

Author. Koizumi (1973a, b).

Category. Interval Zone.

Definition. The base is defined by a horizon just above the last occurrence of $N$. kamtschatica, and the top by the last occurrence of Thalassiosira antiqua.

Characteristic flora. Assemblages of this zone are dominated by $N$. koizumii.

Age. late Pliocene, 2.4-1.7 Ma (Barron, 1980a).

\section{Actinocyclus oculatus Zone (NPD10)}

Author. Donahue (1970), Koizumi (1973b).

Category. Partial-range Zone.

Definition. The base is defined by a horizon just above the last occurrence of Thalassiosira antiqua, and the top by the last occurrence of $A$. oculatus.

Characteristic flora. Assemblages are dominated by such species as Neodenticula koizumii, $N$. seminae, and A. oculatus.

Age. Quaternary, 1.7-0.9 Ma (Donahue, 1970; Barron, 1980a).

\section{Rhizosolenia curvirostris Zone (NPD11)}

Author. Donahue (1970).

Category. Partial-Range Zone.

Definition. The base is defined by a horizon just above the last occurrence of Actinocyclus oculatus, and the top by the last occurrence of $R$. curvirostris.

Characteristic flora. Assemblages are dominated by Neodenticula seminae and characterized by the occurrence of $R$. curvirostris.

Age. Quaternary, 0.9-0.25 Ma (Donahue, 1970; Barron, 1980a, in press a).

\section{Neodenticula seminae Zone (NPD12)}

Author. Donahue (1970).

Category. Partial-Range Zone.

Definition. Interval containing $N$. seminae above the last occurrence of Rhizosolenia curvirostris.

Characteristic flora. Assemblages of this zone are composed of extant species, most of which are described in detail by Sancetta (1982).

Age. Quaternary, 0.25-0 Ma (Donahue, 1970; Barron, in press a).

\section{OCCURRENCE OF RESTING SPORES OF CHAETOCEROS}

Resting spores of Chaetoceros and its allied forms frequently occur in association with normal fossil diatom valves in near-shore sediments. These spores have been largely neglected in both biostratigraphic and paleoenvironmental analyses of diatoms until now, perhaps because their taxonomy was so poorly understood and because their general morphology is so monstrous that they were not recognized as diatoms. Most other neritic and planktonic genera of the centric diatoms, such as Stephanopyxis and Thalassiosira, are also known to bear resting spores, but their morphology resembles their mother cells, although the resting spores are more heavily silicified than the mother cells and have a tendency to be heterovalvate in general. Consequently, the latter have been treated as normal diatom valves in fossil material, either consciously or unconsciously. Such treatment is also followed in this chapter; only resting spores of Chaetoceros and closely allied forms of uncertain generic position are separately recorded along with the total number of specimens encountered during the routine 100 count of "usual" diatom valves. 
Chaetoceros resting spores occur in Holes 584 and $438 \mathrm{~A}$ and in the four on-land sequences from Japan and California (Fig. 8). Samples from Hole 438A are composed of those described in the previous biostratigraphy section and those described by Akiba (1982a). Samples from the Nakayama-Toge Section of Sado Island are identical to those of Yamanoi (1978). Samples from two sections of the Atsunai Area, eastern Hokkaido, are those of Akiba (1982a). Samples from the Newport Beach Section, California, are those of Barron (1976) and Barron and Keller (1983).

Resting spores are very abundant at two horizons in Hole 584. One is an upper upper Miocene interval ranging from the base of the Thalassionema schraderi Zone through the middle part of the overlying Rouxia californica Zone (Figs. 6, 8). The second is a thin Quaternary section, where the number of Chaetoceros generally exceed 100 , sometimes more than 200 , whereas numbers of resting spores in other intervals are consistently less than 100, although several minor peaks are recognized. A large hiatus is suggested for the base of the T. schraderi Zone of this hole, as mentioned before. Such a mass occurrence of resting spores in the upper upper Miocene is also recognized in Hole 438A. The base of the occurrence is coincident with the base of the $T$. schraderi Zone, as is the case in Hole 584, and its top is also in the middle part of $R$. californica Zone (Fig. 8). Comparison of resting spore frequencies between these two holes suggests that even several of the minor abundance fluctuations are also correlative with each other; for example, a small peak in the upper part of the Thalassiosira yabei Zone and a very low trough in the Denticulopsis dimorpha Zone in the two holes.

In the two on-land sequences of eastern Hokkaido (Fig. 8), very conspicuous, but restricted, mass occurrences of resting spores are observed in the Atsunai Formation, which belongs to the Thalasseionema schraderi Zone. Evidently, more resting spores occur in these sections than in Holes 584 and 438A, and, in some samples from the Kobukariishi Section, the numbers exceed more than 1000 , although frequencies exceeding 500 are truncated in Figure 8. Both the base and the top of the Atsuani Formation in the two sections are bound by unconformities, in which the $D$. katayamae Zone at the base and the $R$. californica Zone at the top are missing. The patterns of frequency distribution of resting spores observed in the $T$. schraderi Zone of these two on-land sequences and Hole 438A are very similar, and several peaks and troughs in the interval may be correlatable. Another on-land sequence from Sado Island in the Japan Sea, however, does not show any noticeable abundance of resting spores, in spite of the fact that the sequence spans all five diatom zones, from the upper Miocene $D$. dimorpha Zone through the uppermost upper Miocene to lower Pliocene Neodenticula kamtschatica Zone.

In the Newport Beach Section, California (Fig. 8), fluctuating but very high occurrences of the resting spores are restricted to Barron and Keller's (1983) Nitzschia reinholdii Zone, the lower part of which is safely assigned to both the upper part of the $T$. schraderi Zone and $R$. californica Zone at the same time. The upper part of the Nitzschia reinholdii Zone is possibly correlative with the Neodenticula kamtschatica Zone, but the latter zone is not applicable operationally to this section because it lacks $N$. kamtschatica. The base of the resting spore high-frequency interval coincides with an unconformity at the base of the $N$. reinholdii Zone (Barron and Keller, 1983). Accordingly, resting spores occur in abundance at similar horizons in several sequences of the northwestern and northeastern Pacific, although the mass occurrences of resting spores in the latter area are shifted slightly to younger horizons.

The occurrences of resting spores suggest significant paleoenvironmental implications for these sequences. Such implications are not easy to clarify, because almost no data on the relationship between distributions of the resting spores and hydrographic conditions including water depth and current conditions are available. Sancetta (1982), who incorporated only the part of resting spores of Chaetoceros that could specifically be identified into her modern diatom thanatocoenosis of the Bering Sea, remarked that areas with high frequencies of selected Chaetoceros resting spores correspond to those of high productivity. At the same time she also cautioned that their relative frequencies might be subjected to winnowing by bottom currents, obscuring any primary relationship. Another explanation for the abundance of Chaetoceros resting spores, however, is one that relies on the influence of neritic or shallow-water environments. Akiba and Ichinoseki (1983) noted the mass occurrences of the resting spores in the Atsunai sections and in Hole $438 \mathrm{~A}$ and suggested that they might indicate a shallower basin environment induced by a world-wide eustatic sea-level drop in the Messinian. However, the following facts suggest that this interpretation is not possible: (1) the interval of mass resting spore occurrences of the area is much older than the Messinian; (2) similar mass occurrence in a Californian section is shifted to younger horizons than those of Japan, and (3) mass occurrence of resting spores is not observed on Sado Island in the Japan Sea.

These facts suggest that mass occurrences of resting spores from the base of the T. schraderi Zone through the middle part of the $R$. californica Zone in Japan (about 9-7 Ma) record a particular geologic event restricted to the area around the two DSDP sites off northeastern Honshu and eastern Hokkaido. Along this line, Niitsuma's (1978) subduction model proposes that the Pacific side of northeastern Honshu rose temporarily in the late late Miocene because of the breakdown of a long slab of the Pacific Plate, which had been subducting before that time. This causal mechanism for uplift of northeastern Honshu would explain the sudden, mass occurrence of Chaetoceros resting spores offshore eastern Honshu and Hokkaido.

Cyclic sub-bottom currents may have induced several widely distributed Miocene hiatuses in the North Pacific (Barron and Keller, 1983). If mass occurrences of Chaetoceros result from selective solution or winnowing of diatom assemblages by bottom currents (Sancetta, 1982), then co-occurrence with dissolution-resistant diatoms such 


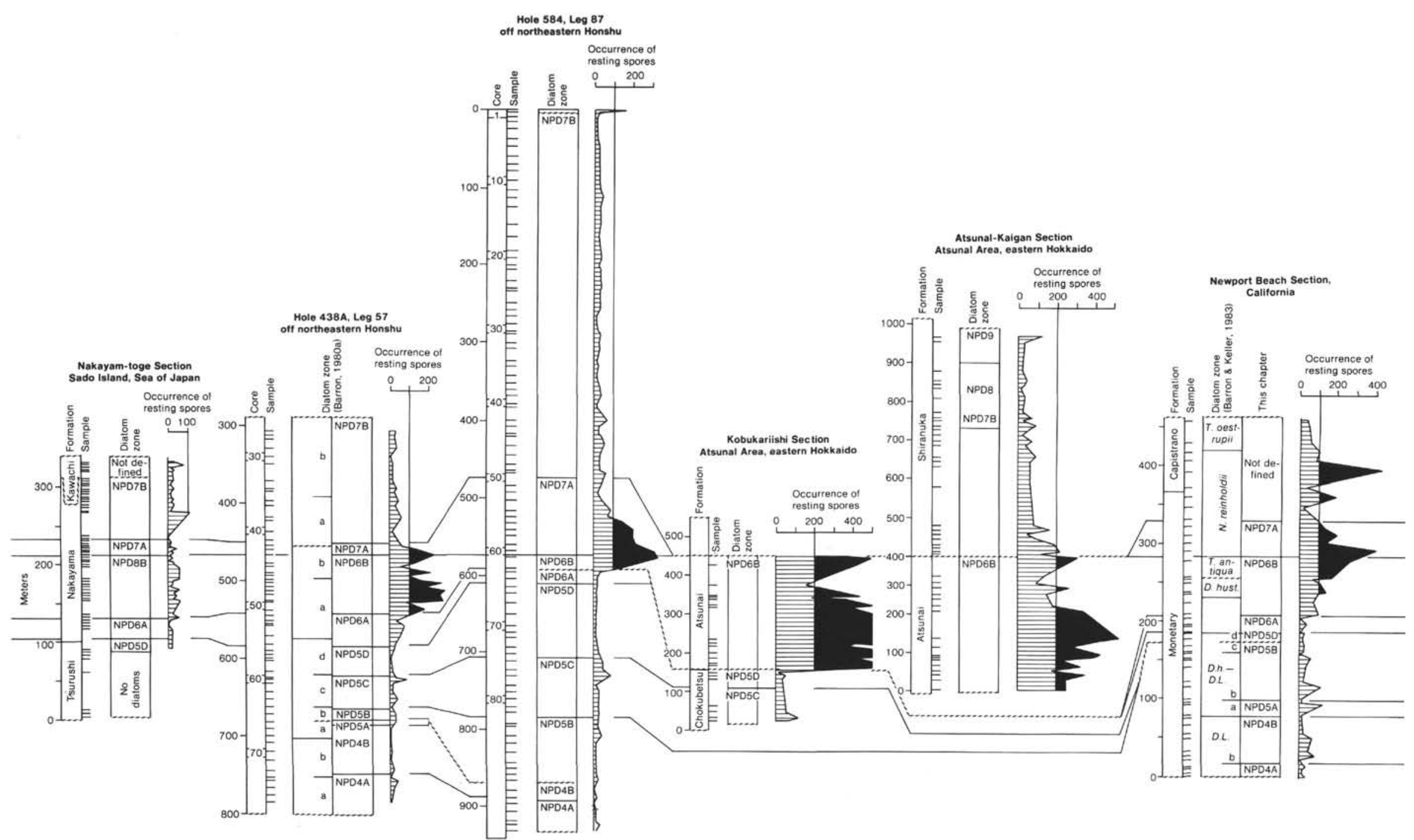

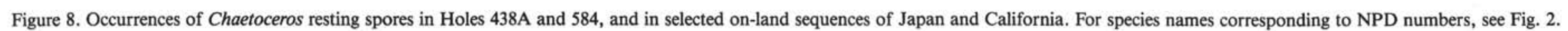


as Coscinodiscus marginatus, T. schraderi, and Synedra jouseana in Hole 584 suggests either selective dissolution or winnowing. The near absence of Chaetoceros resting spores in Hole 183 of Leg 19 (Table 11) then is possibly due to very strong dissolution. However, the question remains unanswered of just how resistant Chaetoceros resting spores are, compared to normal diatom valves. Finally, most of the intervals of mass occurrences of resting spores illustrated in Figure 8 have unconformities at their bases, except at Hole 438A, where there might also be a similar hiatus.

\section{AGE VERSUS DEPTH PLOT OF HOLE 584 AND PALEOMAGNETIC CALIBRATION OF DIATOM ZONES}

Except for a very short interval at the base, the entire sequence of Hole 584 was successfully measured for paleomagnetic polarity patterns (Niitsuma, this volume). These polarities are correlated with those of Harland and others (1982), using diatom datum levels (Fig. 9).

The Quaternary/Pliocene boundary is drawn near the top of the Olduvai Event of the Matuyama Epoch and assigned an absolute age of about $1.6 \mathrm{Ma}$ (Haq et al., 1977). This boundary is slightly above the base of the Actinocyclus oculatus Zone. Paleomagnetic correlation of the Quaternary of Hole 584 with the standard section is not possible, because it is very thin (about $4 \mathrm{~m}$ ) and because the main part of the Quaternary $A$. oculatus Zone, upper Pliocene Neodenticula koizumii Zone, and $N$. koizumii- $N$. kamtschatica Zone are missing in a large hiatus around the Quaternary/Pliocene boundary. Paleomagnetic calibration of the Quaternary through Pliocene middle-to-high-latitude diatom zones has been carried out by Donahue (1970), Burckle and Opdyke (1977), and Barron (1980a); these schemes are followed in this chapter.

The Pliocene/Miocene boundary is placed at the Gilbert Epoch/Epoch 5 boundary and its age estimated as 5.2 Ma (Ryan et al., 1974). The present paleomagnetic calibration of lower Pliocene through upper upper Miocene suggests that this boundary is in the lowermost part of the $N$. kamtschatica Zone, at absolute age of about $5.4 \mathrm{Ma}$. The boundary is nearly identical to the last occurrence of Rouxia californica as suggested by Barron (1980a). The calibration also gives a suggested age of about $6 \mathrm{Ma}$ for the top of the $R$. californica Zone. Paleomagnetic calibration of the Thalassionema schraderi and Denticulopsis katayamae zones is not successful at present because of a second large hiatus at the base of the T. schraderi Zone. The base of the zone is estimated to be $9.0 \mathrm{Ma}$ based on data from Hole 438A (Barron, 1980a; this chapter).

The upper Miocene/middle Miocene boundary is near the lowermost part of Epoch 11 at an estimated age of 12.0 Ma (Ryan et al., 1974). Our paleomagnetic calibration places this boundary in the lower part of the Thalassiosira yabei Zone, at an estimated age of $11.9 \mathrm{Ma}$. It also predicts ages for the following two diatom zonal boundaries: $10.4 \mathrm{Ma}$ for the top of the $D$. dimorpha Zone and 11.3 Ma for the top of the T. yabei Zone.

Paleomagnetic calibration for the remaining diatom zones older than the early part of the $D$. praedimorpha
Zone are not successful mainly because of a third conspicuous hiatus in Hole 584 at the base of the D. praedimorpha Zone. Estimated ages for those zones are inferred from Barron (1980a, 1981, in press a).

The middle Miocene/lower Miocene boundary correlates with the upper part of Epoch 16, both at an estimated age of 15.5 Ma (Ryan et al., 1974). Barron (1980a) suggested that the first occurrence of $D$. lauta and hence the base of the D. lauta Zone closely approximate the boundary. The absolute age value was changed to $15.9 \mathrm{Ma}$ (Barron, in press a) because of a change of standard paleomagnetic polarity patterns.

\section{HIATUSES}

Large hiatuses recognized in Hole 584 at the Quaternary/Pliocene boundary, within the upper Miocene, and within the middle Miocene also occur in many on-land sequences from Hokkaido and northeastern Honshu (Figs. 10 and 11 and Tsuchi et al., 1981a, b; Akiba and Ichinoseki, 1983).

The hiatus in the middle Miocene of the Hole 584 occurs between 584-91,CC and 584-92,CC and is recognized by the lack of a Crucidenticula nicobarica Zone and possibly the upper part of the underlying Denticulopsis hyalina Zone. This hiatus correlates with one in Hole 438A, found between 438A-65, CC and 438A-66-2 (Barron, 1980a). The middle Miocene hiatus is widely recognized in various on-land sequences of Japan (Fig. 10) and has various magnitudes. In particular, this hiatus is very conspicuous in northern Hokkaido, where the main part of the middle Miocene, represented by the $C$. nicobarica Zone and $D$. praedimorpha Zone, is consistently missing. Similar hiatuses also occur in central and eastern Hokkaido, although hiatuses in central Hokkaido have much shorter intervals and are only locally recognizable because of extensive distributions of the socalled hard shales (solid black in Fig. 10).

A hiatus in the upper Miocene of Hole 584, between 584-63-2 and 584-63,CC (Fig. 9) may represent the lower part of the Thalassionema schraderi Zone and the upper part of the D. katayamae Zone. It is also marked by the base of the mass occurrence of Chaetoceros resting spores as previously described. Barron (1980a) recognized an upper Miocene hiatus in Hole 438A between Sections $438 \mathrm{~A}-42-3$ and $438 \mathrm{~A}-42-5$, but that horizon is slightly younger than the one in Hole 584, which occurs in the Rouxia californica Zone of this chapter. Occurrences of Chaetoceros resting spores in Hole 438A, however, suggest another upper Miocene hiatus correlative with that of Hole 584. The upper Miocene hiatuses are also widely recognized in many Hokkaido sequences, where the $D$. katayamae Zone is consistently missing. These gaps correspond to the two recognized in Hole 584, but in some cases (for example, in the Atsunai Area of eastern Hokkaido; Section 11 of Fig. 10) a hiatus also correlates with the one recognized in Hole 438A. An upper Miocene hiatus in Piston Core RC 12-381 from the Japan Sea may also be correlative with one in Hole 438A.

A hiatus near the Quaternary/Pliocene boundary in Hole 584 is also very widely observed in many on-land sequences of Japan. Quaternary diatomaceous deposits 


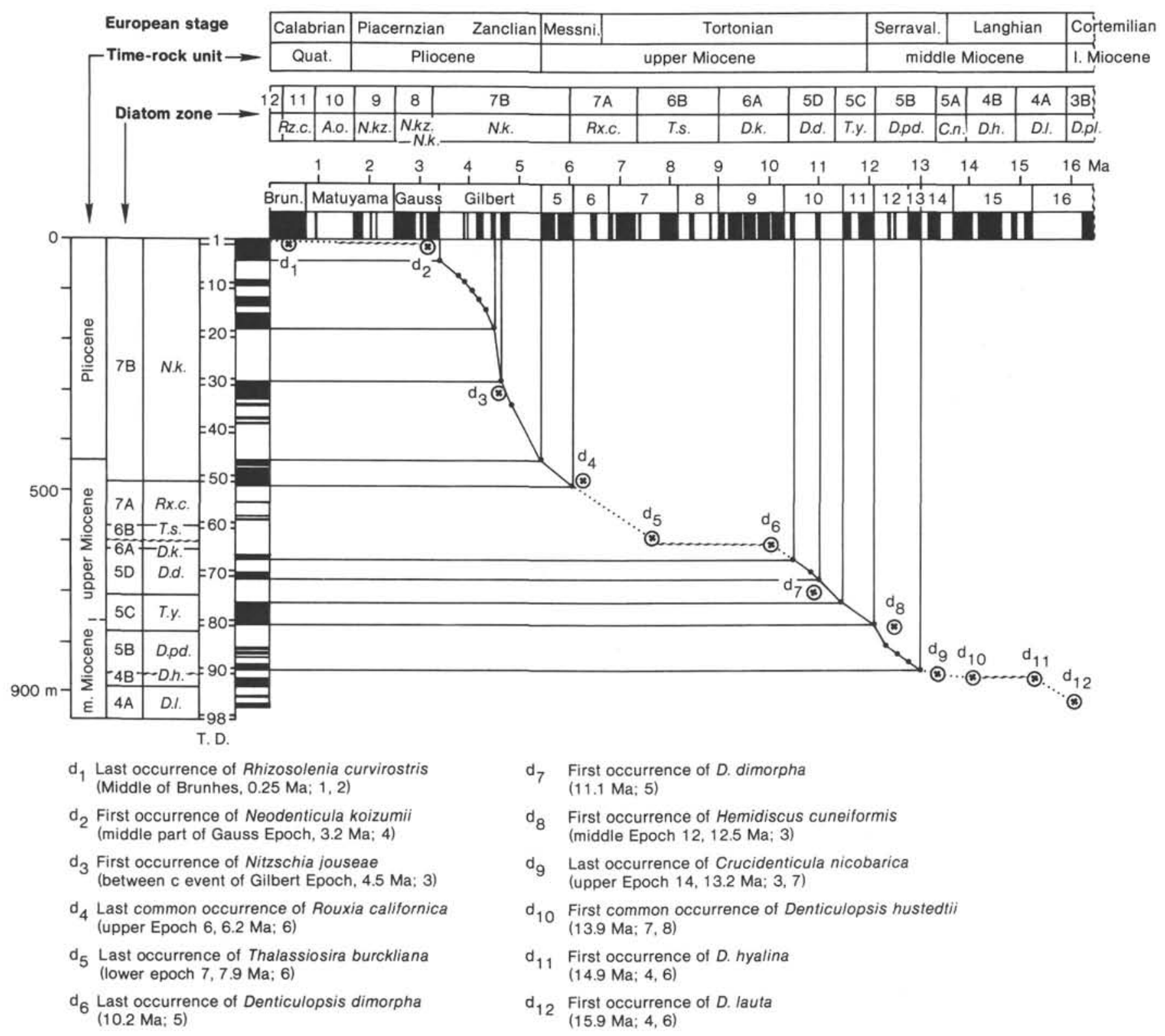

References: 1. Donahue, 1970. 2. Burckle and Opdyke, 1977. 3. Burckle, 1978. 4. Barron, 1980a. 5. Barron, 1981. 6. Barron, in press a. 7. Barron, in press b. 8. Koizumi, 1977.

Figure 9. Age versus depth plot and paleomagnetic calibration of diatom zones, Hole 584. For complete spelling of zonal names, see Figure 2.

in these sequences are generally represented by admixtures of abundant reworked diatoms and fewer indigenous ones; therefore, precise age determinations are not always easy. Either by chance or by very detailed examinations, Quaternary marker species such as Rhizosolenia curvirostris or Pseudoeunotia doliolus are found in samples from those strata (Akiba and Ichinoseki, 1983).

Hiatuses in these diatomaceous sedimentary sequences may be indicators of local or regional paleoceanographic change or of tectonic movement. Recently, many geographically long-ranging, deep-sea Miocene hiatuses have been recognized in the North Pacific, and most are interpreted in terms of cyclic developments of intense bottom currents induced by the formation of thick ice sheets in the Antarctic (Barron, 1980a, 1981; Barron and
Keller, 1982, 1983). Some of the previously-mentioned hiatuses might also be caused by such bottom currents. For example, hiatuses recognized in the upper Miocene $R$. californica and T. schraderi zones might be correlative with hiatuses NH6 and NH5 (Barron and Keller, 1982), respectively. These hiatuses might also be interpreted in terms of an upper Miocene tectonic movement restricted to Japan and its environs (see section on Chaetoceros resting spores, this chapter). The middle Miocene hiatuses in Japanese Neogene strata are also recognized by studies of foraminiferal biostratigraphy, tectonic developments, and so forth. Ujiié $(1979,1981,1982)$ repeatedly stressed the very intimate relationship of the hiatuses with a sudden enlargement of the Japan Sea. The possible relationship between those hiatuses and the 


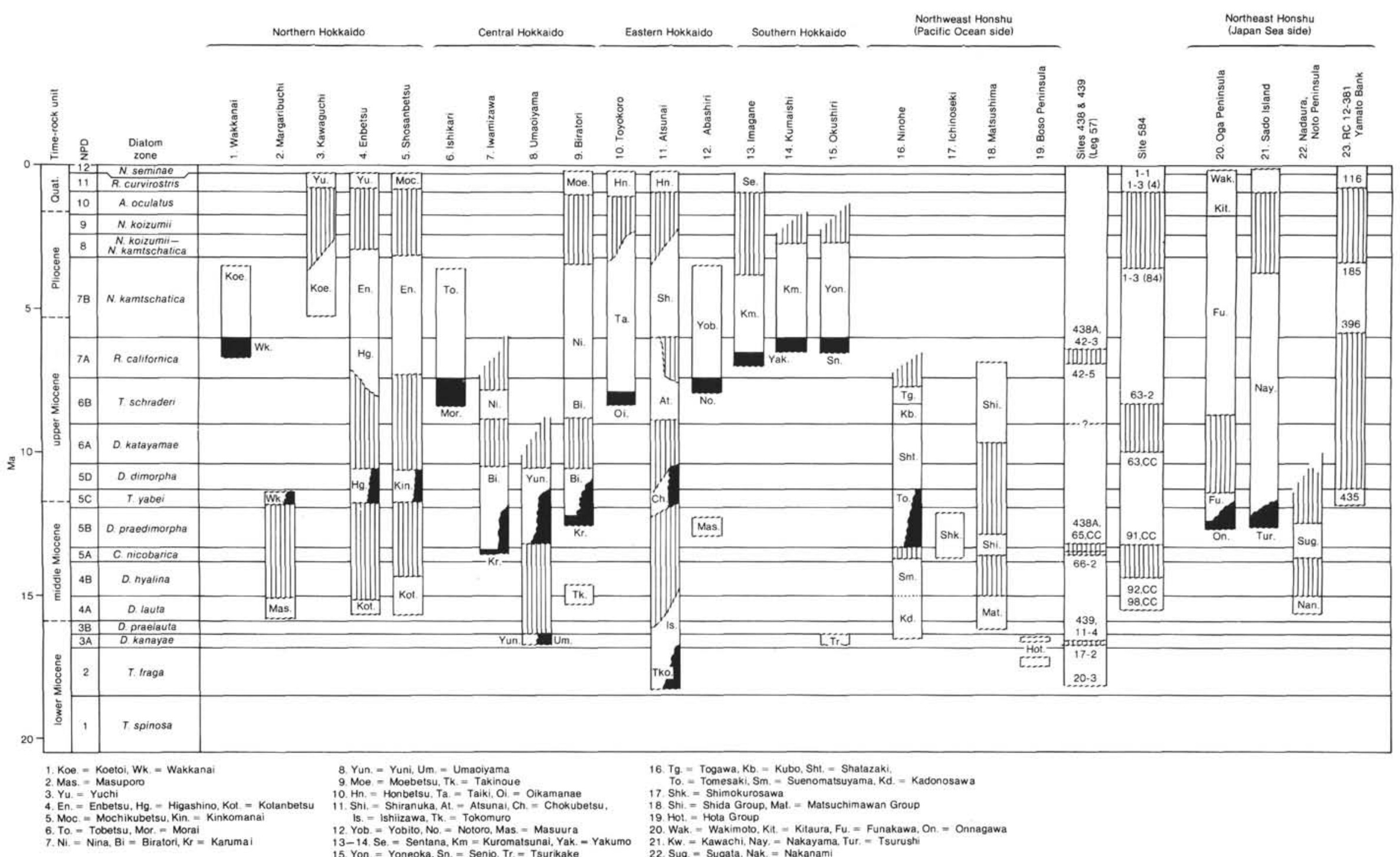

Figure 10. Correlation of selected Neogene diatomaceous sequences in Hokkaido and northeastern Honshu, Japan and in Holes 438A and 584. Sections are located in Figure 11. Lined areas denote stratigraphic gaps. Strata with solid black are hard shales without diatoms. For complete names of diatom zones, see Figure 2. 


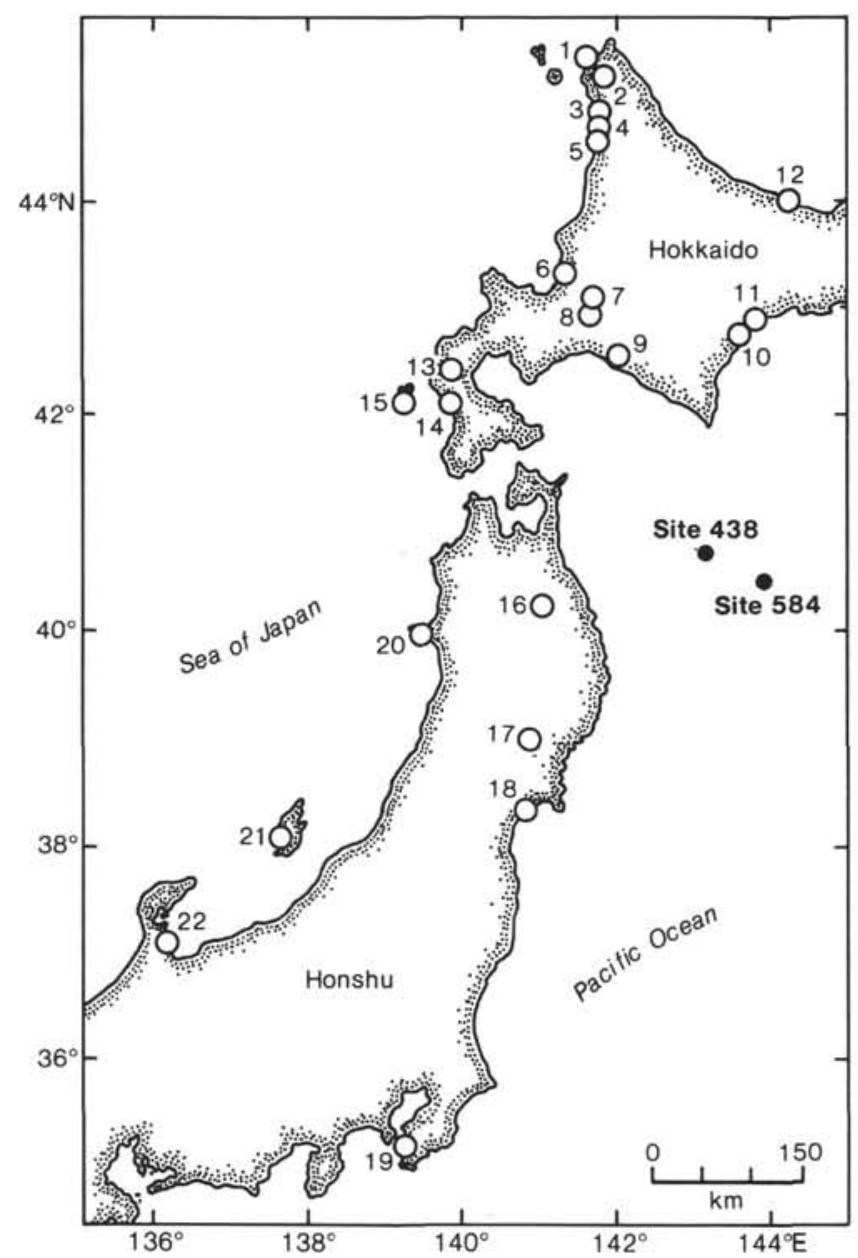

Figure 11. Locations of on-land sequences described in Figure 10. The location of a piston core, RC-12381, from the Yamato Bank of the Japan Sea $\left(38^{\circ} 55^{\prime} \mathrm{N}, 133^{\circ} 48^{\prime} \mathrm{E}\right.$; water depth $\left.1427 \mathrm{~m}\right)$ is excluded from this figure (23 in Fig. 10).

tectonic development of the area is the subject of another chapter (Niitsuma and Akiba, this volume).

\section{DESCRIPTION OF NEW TAXA AND TRANSFER OF TAXA}

\section{Delphineis sheshukovae Akiba n. sp.} (Plate 20, Figs. 16-17)

Description. Valve broad-linear with broadly rounded apices, 20$32 \mu \mathrm{m}$ long, about $10 \mu \mathrm{m}$ wide. Transapical striae dense, 16-18 striae in $10 \mu \mathrm{m}$, parallel to transapical axis near center and radial to outwardly concave near apices. Striae punctate, not wholly punctate over valve face, but from margin to near apical axis in the central part and only at margin near apices, $16-18$ punctae in $10 \mu \mathrm{m}$.

Remarks. No similar Delphineis species was found in the literature. This new species has, possibly, the finest transapical striae in the genus. This species is found in only one sample of Hole 584, the middle part of the Neodenticula kamtschatica Zone (lower Pliocene). This species is dedicated sincerely to Dr. V. S. Sheshukova-Poretzkaya, Leningrad, who contributed much to the taxonomy of Neogene diatoms of the North Pacific high latitudes. Her works, especially that published in 1967, were quite useful to this study.

Holotype. Plate 20, Figure 17; Sample 584-32,CC; slide no. Zu 3/ 26 deposited in the Hustedt Collection, Bremerhaven; $22 \mu \mathrm{m}$ in length and about $10 \mu \mathrm{m}$ wide.

Paratype. Plate 20, Figure 16 from the same slide as above, $25 \mu \mathrm{m}$ in length and $10.5 \mu \mathrm{m}$ wide.
Delphineis simonsenii (Mertz) Akiba, n. comb. (Plate 20, Figs. 12-13)

Basionym. Rhaphoneis simonseni Mertz, 1966, p. 28, pl. 5 figs. 57-59.

Remarks. This species resembles $D$. novaecaesarae (Kaim and Schultze) Andrews (1977, p. 251; pl. 1, figs. 8-11; pl. 2, figs. 23-24; pl. 3, figs. 31-32) and Rhaponeis sachalinensis Sheshukova-Poretzkaya (1967, p. 242, pl. 42, fig. 2), but is distinguished from the former by the rounded apices and from the latter by more conspicuously attenuated apices and inflated central part. It also resembles Rhaponeis ossiformis Schrader (Schrader and Fenner, 1976, p. 995, pl. 5, fig. 20), but differs from the latter by shorter valves and narrower pseudoraphe. The species occurs commonly in and is limited to the upper part of the lower Pliocene Neodenticula kamtschatica Zone recognized in Holes 584 and 438A. No significant morphologic differences are noticed between these specimens and those originally described from Pliocene sediment of South America. However, more detailed comparisons of specimens from these two widely separated areas are needed, because morphologically closely related but distinct species were frequently grouped together in the past when new taxonomic combinations were made without detailed examination of type materials; some examples are Thalassiosira decipiens (Grunow) Joergensen (Hasle, 1979); Nitzschia pliocena (Brun) Mertz (Kanaya and Koizumi, 1970; Akiba and Yanagisawa, this volume); and Thalassionema hirosakiensis (Kanaya) Schrader (Akiba, 1982a).

\section{Denticulopsis praelauta Akiba and Koizumi, n. sp.}

(Plate 26, Figs. 10-14)

Synonym. Denticula sp. cf. lauta Bailey, Barron, 1980a, p. 672, pl. 1, figs. 13-14; Denticulopsis sp. A, Akiba et al., 1982, pl. 3, figs. 41-44.

Description. Valve narrowly linear with rounded apices, 8-16 $\mu \mathrm{m}$ long, $2.5-5.5 \mu \mathrm{m}$ wide. Pseudosepta moderately developed, 5-8 (mostly 5-6) pseudosepta in $10 \mu \mathrm{m}$, no secondary pseudosepta present, but one apical pseudoseptum present at each apex. Marginal ribs generally absent, but in some cases very poorly developed. Frustule rectangular with rounded corners, 6-7 $\mu \mathrm{m}$ in depth. A row of punctae of intercalary bands either present or missing. Transapical striae fine, almost invisible in smaller specimens, under light microscope, but in larger specimens $25-30$ striae in $10 \mu \mathrm{m}$ are observed, striae punctate, about 25 punctae in $10 \mu \mathrm{m}$. Raphe marginal.

Remarks. This species is similar to D. lauta (Bailey) Simonsen, but is distinguished from it by the absence (or very weak development) of marginal ribs and generally smaller and narrower valves. This new form is evidently an ancestral species of $D$. lauta. Some specimens have poorly developed marginal ribs intermediate between individuals typical of each of these two species, but specimens lacking marginal ribs even under lower focus should be identified with $D$. praelauta.

Stratigraphic occurrence. Common to abundant in the $D$. praelauta Zone (NPD3B) with a short overlapped range with $D$. lauta in the lower part of the $D$. lauta Zone (NPD4A).

Holotype. Plate 26, Figure 10; Sample 439-8-6, 49-52 cm from Leg 57; slide no. $\mathrm{Zu} \mathrm{3/13}$ deposited in the Husted Collection, Bremerhaven; $15 \mu \mathrm{m}$ in length, about $3 \mu \mathrm{m}$ in width.

Paratype. Plate 26, Figure 14 from the same slide as above, $14 \mu \mathrm{m}$ in length, $6.5 \mu \mathrm{m}$ in depth (frustule).

\section{Genus IKEBEA Komura (1975)}

Ikebea tenuis (Brun) Akiba, n. comb. (Plate 19, Figs. 1-5)

Basionym. Goniothecium tenue Brun, 1894, Diatomiste, II, p. 77, table 5, figs. 5-6.

Synonym. Goniothecium tenue Brun, Sheshukova-Poretzkaya, 1967, p. 232 , pl. 34 , figs. $6 a-b$, pl. 40 , figs. $5 a-b$; Koizumi, 1973 b, p. 833 , pl. 7, figs. 7-9; Schrader and Fenner, 1976, p. 983, pl. 6, figs. 6-10, pl. 37, figs. 7-10; Barron, $1980 \mathrm{a}$, pl. 4, fig. 2; Goniothecium tenue var. structuralis Schrader and Fenner, 1976, nom. invalid., p. 983, pl. 37, figs. 6, 8, 9; Ikebea amphistriata Komura, 1975, p. 135, textfigs. 2-5, pl. 12, figs. 1-5; Ikebea bifurcata Komura, 1975, p. 136, text-figs. 8-9, pl. 12, figs. 11-13; Ikebea clavata Komura, 1975, p. 138, text-figs. 12-14, pl. 12, figs. 14-16; ? Ikebea coronata Komura, 1975, p. 137, text-figs. 10-11, pl. 12, figs. 9-10; ? Ikebea robusta Komura, 
1975 , p. 136 , text-figs. $6-7$, pl. 12, figs. 6, 8; Kannoa japonica Komura, 1980 , p. 374 , text-fig. 2, pl. 46, figs. 1-12; Kannoa hastata Komura, 1980 , p. 376 , text-fig. 3 , pl. 46 , figs. 13 a-b.

Remarks. Heterovalvate outline and other structural differences are enough to warrant transferring this peculiarly shaped extinct diatom, Goniothecium tenue to Ikebea. Goniothecium is generally regarded as a resting spore of Chaetoceros (Hendey, 1964). Perhaps Ikebea is also a resting spore of Kannoa (Komura, 1980, p. 373), because colonies of Ikebea and Kannoa valves, the former being inside, were observed in an extremely well-preserved lower Miocene (Thalassiosira fraga Zone) diatom flora from a calcareous nodule, Boso Peninsula, central Japan. Vegetative valves of this species, "Kannoa" are similar to Asterionella species recognized in modern diatom flora (Komura, 1980), but no resting spore formations have been recognized in Asterionella species. In addition, Ikebea tenuis presumably forms colonies by contact between valve faces, but Asterionella species forms colonies by contact of only the apical portions of valves (Hustedt, 1932).

Stratigraphic occurrence. Ikebea tenuis occurs commonly and consistently in Miocene sequences of the northwestern Pacific, but no occurrences of the species have been recorded from the northeastern $\mathrm{Pa}$ cific. Schrader and Fenner (1976) recognized this species in Miocene sediment of the Norwegian Sea and claimed that Schrader (1973a) observed the species recorded as Thalassionema nitzschioides (Schrader, 1973a, pl. 23, figs. 12, 13) in samples from DSDP Leg 18 sites, off California. The latter occurrence is probably not the same species. In the northwestern Pacific, this species occurs very abundantly in the Thalassiosira fraga Zone, and from that horizon is a common member of the Miocene diatom flora. Its last occurrence coincides with that of Rouxia californica and with the first occurrence of Rossiella tatsunokuchiensis as previously stated, and it approximates the Miocene/Pliocene boundary.

\section{Kisseleviella ezoensis Akiba, n. sp.} (Plate 19, Figs. 13-16)

Description. Valve quadrangular in its basic shape, slightly inflated in the middle with steeply attenuated apices, $16-30 \mu \mathrm{m}$ long, about $10 \mu \mathrm{m}$ wide. Several tubercles, either spiny or annular, form a transapically elongated crown in the center of the valve, and other tubercles, occasionally united, form smaller crowns near each apex. Valve face has irregularly distributed small punctae.

Remarks. This new Kisseleviella species is easily distinguished from $K$. carina Sheshukova-Poretzkaya, a generic type species, by its steeply attenuated apices and transapically elongated central crown. Presently recognized specimens may represent resting spores of the species.

Stratigraphic occurrence. This species is common and restricted to the lower Miocene Thalassiosira fraga Zone (NPD2) recognized in DSDP Site 439 and the lower Miocene strata distributed in the Kiroro and Tokomuro formations of the Atsunai and Honbetsu areas, eastern Hokkaido (Akiba and Ichinoseki, 1983).

Holotype. Plate 19, Figure 16 from Sample JDS-8482, the Kiroro Formation outcropped in the vicinity of Honbetsu-cho, eastern Hokkaido, slide no. $\mathrm{Zu} \mathrm{3/19}$ deposited in the Hustedt Collection, Bremerhaven, $22.5 \mu \mathrm{m}$ in length, $10 \mu \mathrm{m}$ in width.

Paratype. Plate 19, Figure 15 from the same slide as holotype; 17 $\mu \mathrm{m}$ in length, about $10 \mu \mathrm{m}$ in width.

Derivation of name. The ancient name of Hokkaido was "Ezo".

\section{Nitzschia umaoiensis Akiba, n. sp.}

$$
\text { (Plate 23, Figs. 1-2) }
$$

Synonym. Nitzschia heteropolica Schrader, in Barron, 1980a, pl. 2, fig. 7 ; pl. 4, fig. 9 .

Description. Valve lanceolate in its basic shape. Transapical axis heteropole and apical axis sometimes slightly heteropole. Valve $30-70 \mu \mathrm{m}$ long, about $10 \mu \mathrm{m}$ wide. Costae very robust and coarse, about 6 in $10 \mu \mathrm{m}$, transapical near center and towards each apex becoming outwardly concave. Intercostal membrane striate, double rows of striae between each two costae, striae coarsely punctate, about 20 punctae in $10 \mu \mathrm{m}$. Punctae slightly apically elongated. Raphe marginal.

Remarks. This new species is similar to such species as Nitzschia praefossilis Schrader (1973a, p. 708, pl. 5, figs. 19, 21, 22); N. praereinholdii Schrader (1973a, p. 708, pl. 5, figs. 20, 23-26); and N. heteropolica Schrader (1973a, p. 707, pl. 26, figs. 1-2). It is distinguished from those species by much coarser transapical costae and striae.
Stratigraphic occurrence. This new species is generally limited to the Denticulopsis praedimorpha Zone (NPDSB) in the northwestern Pacific. Its occurrences in Sites 584 and 438A are rare, but in its type locality in Hokkaido it occurs very abundantly. This extinct species and Nitzschia pliocena (Brun) Mertz are probably cold-water forms.

Holotype. Plate 23, Figure 1, Sample JDS-3664, the Yuni Formation outcropped in the vicinity of Yuni-cho, Umaoiyama Area, central Hokkaido; slide no. Zu 3/20 deposited in the Hustedt Collection, Bremerhaven; $40.5 \mu \mathrm{m}$ in length, $10 \mu \mathrm{m}$ in width.

Paratype. Plate 23, Figure 2 from the same slide as holotype; $40.5 \mu \mathrm{m}$ in length, about $10 \mu \mathrm{m}$ in width.

\section{Thalassiosira delicata (Barron) Akiba, stat. nov. (no illustration)}

Synonym. Thalassiosira nidulus var. delicata Barron, 1980a, p. 671, pl. 6 , figs. 1,4 .

Remarks. Its distinct morphology and a stratigraphic range different from those of Thalassiosira nidulus (Tempère and Brun) Jousé are, I believe, enough to treat this taxon as a separate species.

\section{Thalassiosira jouseae Akiba, n. sp.}

(Plate 6, Figs. 8-10)

Synonym. Thalassiosira indefinita Jousé, 1959, pl. 4, fig. 16, nom. nud.: Thalassiosira nidulus (Tempère and Brun) Jousé, 1961, p. 63, pl. 3, figs. 4-5; Koizumi, 1973b, in part, pl. 7, fig. 26, not 25; 1975a, pl. 4, figs. 27-28; 1975c, pl. 2, fig. 17; Koizumi and Ujiié, 1976, pl. 12, fig. 2; Harper, 1977b, p. 90, pl. 3,figs. 13-14; Barron, 1980a, p. 673, pl. 6 , fig. 5 .

Description. Valve circular, 9-29 $\mu \mathrm{m}$ in diameter. Valve face with slightly depressed center, more or less raised from submarginal zone, sparsely areolated. Areolae quadrangular with variable size, more or less isolated from each other, 8-10 areolae in $10 \mu \mathrm{m}$. Submarginal tapering spines are conspicuous and form a crownlike structure by uniting their basal parts. Marginal zone or margin wide and slanting from valve face, striated with variable density, $4-7$ in $10 \mu \mathrm{m}$ according to specimens.

Remarks. This species closely resembles Thalassiosira nidulus, but is distinguished from it by united basal parts of submarginal spines, smaller valve, and sparser areolae on valve face. It first occurs in the lower part of the lower Pliocene Neodenticula kamtschatica Zone of Hole 584, whereas T. nidulus s.s. first occurs in the upper Miocene Denticulopsis dimorpha Zone of Hole 438A. Similar stratigraphic occurrences of the two species have been noted by Harper (1977b) in onland sequences of northern Hokkaido. Their morphological similarities and stratigraphic ranges suggest that the new species evolved from T. nidulus.

Jousé (1961) transferred both species, originally described by Brun and Temperre (1889) as Stephanodiscus elegans Brun from the "Calcaire de Yedo" and as Stephanopyxis nidulus Tempère and Brun from the "Calcaire de Sendai," into Thalassiosira. My reexamination of the type material of both species suggests that (1) Stephanodiscus elegans Brun is not a Thalassiosira species, because the species does not bear either clear areolation or punctae, but it is furnished only with very faint maculation (although that systematic position may not be certain at present), and (2) perhaps Jousé (1961) mixed two species, $T$. nidulus s.s. and the presently described $T$. jouseae n. sp. In other words, $T$. elegans (Brun) Jousé and T. nidulus (Tempère and Brun) Jousé (illustrated by her in 1961) are identical to T. nidulus s.s. and to T. jouseae, respectively. Harper (1977b) has already noticed the possible erroneous taxonomic treatments of so-called T. nidulus, and Barron (1980a) also identified some morphologic differences between its Pliocene and Miocene forms.

Holotype. Plate 6, Figure 8 from Sample JDS-11556, the Shiranuka Formation, Atsunai Area, eastern Hokkaido, slide no. Zu 3/27 deposited in the Hustedt Collection, Bremerhaven, $17 \mu \mathrm{m}$ in diameter.

Paratype. Plate 6, Figure 9 from the same slide as holotype, 18.5 $\mu \mathrm{m}$ in diameter.

\section{Thalassiosira praenidulus Akiba, n. sp.}

(Plate 5, Fig. 7; Plate 6, Figs. 1-3)

Description. Valve circular, $16-42 \mu \mathrm{m}$ in diameter, almost flat, slightly depressed center, where several mucous pores are present. Marginal spines conspicuous and robust with tuliplike structures near their tops, 
about 5 in $10 \mu \mathrm{m}$. Margin $1.5-2 \mu \mathrm{m}$ wide, striated, about 12 striae in $10 \mu \mathrm{m}$. Valve face densely areolated, areolae quadrangular in shape, areolae almost equal in size over entire valve face, 7-9 areolae in $10 \mu \mathrm{m}$, radially arranged, somewhat disordered.

Remarks. This species is similar to T. nidulus (Tempère and Brun) Jousé, but is distinguished from the latter by equally sized areolae, shorter and regularly arranged marginal spines, and a relatively narrower margin.

Stratigraphic occurrence. This species occurs rarely from the Denticulopsis praedimorpha Zone (NPD5B) through the Denticulopsis dimorpha Zone (NPD5D) as recognized in Hole 438A in this chapter and several on-land sequences of Hokkaido (Akiba, unpublished data).

Holotype. Plate 6, Figure 3, Sample JDS-11452, the Chokubetsu Formation, Atsunai Area, eastern Hokkaido, slide no. $\mathrm{Zu} \mathrm{3/21}$ deposited in the Hustedt Collection, Bremerhaven, $26 \mu \mathrm{m}$ in diameter.

Paratype. Plate 6, Figure 1 from same sample as holotype; slide no. $\mathrm{Zu} 3 / 22 ; 41 \mu \mathrm{m}$ in diameter.

\section{Thalassiosira sancettae Akiba, n. sp.}

$$
\text { (Plate 7, Figs. 1-3) }
$$

Synonym. Thalassiosira lacustris (Grunow) Hasle, in Sancetta, 1982, p. 243 , pl. 5, figs. $6-7$.

Description. Valve circular to very broadly elliptical, $18-34 \mu \mathrm{m}$ in diameter, tangentially undulated. Areolae radially arranged, quadrangular, almost same size over entire valve face, 6-7 areolae in $10 \mu \mathrm{m}$. Areolae closely arranged over almost entire valve except at depressed part of plication where they are rather isolated. Margin broad, about $2 \mu \mathrm{m}$ wide, clearly striated, about 15 striae in $10 \mu \mathrm{m}$. A ring of short spines present, sparse, 2 spines in $10 \mu \mathrm{m}$.

Remarks. Sancetta (1982) suggested her specimens might belong to a variety of Thalassiosira lacustris (Grunow) Hasle, "Coscinodiscus" lacustris var. hyperborea Grunow, which is characterized by coarser areolation compared to the type species (10-12 areolae versus about 8 areolae in $10 \mu \mathrm{m}$ ), from which the present species is distinguished by even coarser areolae and also sparser marginal spines. T. lacustris was recently clarified to be a synonym of $T$. bramaputae (Ehrenberg) Håkansson and Locker (1981), from which the new species is structurally quite different, namely the former has somewhat radially elongated areolae, a narrower margin, and denser marginal spines. In addition, T. bramaputae, rare in Holes 582 and 583 from the Nankai Troughpresumably as a displaced diatom, is generally regarded as nonmarine to brackish species, whereas the new species is restricted to marine habitats. Because of their morphologic similarities, T. sancettae $\mathrm{n} . \mathrm{sp}$. might be a last descendant of T. yabei (Kanaya) Akiba and Yanagisawa (this volume) and its closely related species that flourished in Miocene intervals.

Holotype. Plate 7, Figure 1; Sample 584-1-1, 0-3 cm from northwestern Pacific, off northern Honshu, Japan; slide no. Zu 3/14, deposited in the Hustedt Collection, Bremerhaven; longer axis, $30.5 \mu \mathrm{m}$ in length and shorter one, $28 \mu \mathrm{m}$ in length.

Paratype. Plate 7, Figure 2; Sample 584-1-2, 83-85 cm; slide no. JDS-13251 (1), deposited in the JAPEX Collection, Tokyo; longer axis, $18 \mu \mathrm{m}$ in length and shorter one, $17 \mu \mathrm{m}$ in length.

\section{Thalassiosira umaoiensis Akiba, n. sp.}

(Plate 13, Figs. 8-11)

Description. Valve circular, almost flat, $16-30 \mu \mathrm{m}$ in diameter. Areolae quadrangular, forming slightly irregular radial rows, nearly same size in central two-thirds of the radius ( $8-9$ areolae in $10 \mu \mathrm{m})$ and then gradually decreasing in size towards margin, about 15 areolae in $10 \mu \mathrm{m}$ at the margin, where inconspicuous outwardly concave secondary rows of areolae are recognized. Margin striated, about $0.5 \mu \mathrm{m}$ wide, 12-18 striae in $10 \mu \mathrm{m}$. Marginal spines inconspicuous, but in some cases short spines, about 3 in $10 \mu \mathrm{m}$, are observed.

Remarks. This new species is similar to Thalassiosira decipiens (Grunow) Joergensen, but is distinguished from it by finer areolae near the margin, quadrangular (rather than hexagonal) areolae, and clearly different stratigraphic ranges.

Stratigraphic occurrence. This new species occurs rarely in both the Denticulopsis praelauta Zone (NPD3B) in Hole 439 and in the D. praelauta and the Crucidenticula kanayae zones (NPD3A) in several on-land sequences of Japan (Akiba, unpublished data).
Holotype. Plate 13, Figure 9; Sample JDS-12507; the Yuni Formation, Umaoiyama Area, central Hokkaido, slide no. Zu 3/16, deposited in the Hustedt Collection, Bremerhaven; $24 \mu \mathrm{m}$ in diameter.

Paratype. Plate 13, Figure 11 from the same slide as holotype; $29 \mu \mathrm{m}$ in diameter.

\section{Thalassiosira urahoroensis Akiba, n. sp.} (Plate 5, Figs. 1-6)

Description. Valve circular, $18-33 \mu \mathrm{m}$ in diameter, weakly convex with depression in the center, gently curved mantle and hyaline flat margin. Valve face with dense areolae, hexagonal, radially arranged, 12-14 areolae in $10 \mu \mathrm{m}$. Areolae at mantle slightly finer, 16-18 areolae in $10 \mu \mathrm{m}$ in quincunx arrangement. At the edge between valve face and mantle is a row of dense spines, $4-5$ spines in $10 \mu \mathrm{m}$. A cluster of 6-8 mucous pores is recognized in the center of valve; the pores are strutted processes, according to scanning electron microscope results.

Remarks. This extinct species is similar to an extant species, $T$. nordenskioeldii Cleve, but is distinguished from the latter by coarser areolae, hyaline margin, and numerous strutted processes in the center of valve.

Stratigraphic occurrence. In general, this species was observed rarely but is seemingly restricted to the Thalassiosira yabei Zone (NPD5C).

Holotype. Plate 5, Figure 2; Sample JDS-11452; the Chokubetsu Formation outcropped near Urahoro-cho, Atsunai Area, eastern Hokkaido, Japan; slide no. $\mathrm{Zu} \mathrm{3/22}$ deposited in the Hustedt Collection, Bremerhaven; $20 \mu \mathrm{m}$ in diameter.

Paratype. Plate 5, Figure 4 from the same sample as holotype; slide no. JDS-11452 (5) deposited in the JAPEX Collection, Tokyo; $27 \mu \mathrm{m}$ in diameter.

\section{Thalassiothrix robusta (Schrader) Akiba, n. comb.} (Plate 21, Fig. 4)

Basionym. Thalassionema robusta Schrader, 1973: 1973a, p. 712, pl. 3, figs. 24, 35-37.

Synonym. Thalassionema robusta Schrader, Akiba, 1982a, pl. 1, figs. 14-15.

Remarks. This species, superficially similar to Thalassionema schraderi Akiba in that both are heavily silicified and have large and dense marginal striae, has a conspicuous process at one apex and none at the other, whereas the latter species does not have such a spine. The process is recognized by careful examination with a light microscope, but is easily discernible with a scanning electron microscope. The form is clearly distinguished from the recently established Thalassiothrix pseudonitzschioides Schuette and Schrader (1982, p. 214, pls. 1-5, figs. 130 ) by a much more heavily silicified and lanceolate valve.

\section{FLORAL AND ILLUSTRATION REFERENCE}

Most of the diatom species discussed in this chapter are referred to below separately under the marine planktonic, marine tychopelagic and benthic, or nonmarine diatom sections. More detailed treatments of the zonal marker species of the modified Neogene diatom zones for the middle-to-high latitudes of the North Pacific presented in this chapter will be found in Akiba and Yanagisawa (this volume).

\section{Marine Planktonic Diatoms}

Actinocyclus curvatulus Janisch in Schmidt, 1878; Hustedt, 1929, Kieselalg., I, p. 538, fig. 307; Koizumi, 1973b, p. 831, pl. 1, figs. 1-6; Simonsen, 1974, p. 20; Sancetta, 1982, p. 222, pl. 1, figs. 1-3. Synonym: Actinocyclus divisus (Grunow) Hustedt, 1958, p. 129, fig. 81; Koizumi, 1973b, p. 831, pl. 1, figs. 7-12; Coscinodiscus curvatulus Grunow, Hustedt, 1928, Kieselalg., I, p. 407, figs. 214a-b; Coscinodiscus divisus Grunow, Hustedt, 1928, Kieselalg., I, p. 410 , figs. $218 \mathrm{a}-\mathrm{b}$.

Actinocyclus ellipticus Grunow in Van Heurck, 1881; Hustedt, 1929, Kieselalg., I, p. 533, fig. 303.

(Plate 16, Fig. 5)

Actinocyclus ellipticus var. elongatus (Grunow) Kolbe, 1954: p. 20, pl. 3, figs. 28, 31; Schrader, 1974a, pl. 17, fig. 3; Koizumi, 1980, pl. 1, fig. 21.

(Plate 16, Fig. 11)

Actinocyclus ellipticus f. lanceolata Kolbe, 1954: p. 20, pl. 3, fig. 27; Kobayashi et al., 1971, p. 1059, fig. 5.4; Koizumi, 1980, pl. 1, fig. 20.

(Plate 16, Fig. 10) 
Actinocyclus ingens Rattray 1890: p. 149, pl. 11, fig. 7; Kanaya, 1959, p. 97, pl. 7, figs. 6-9, pl. 8, figs. 1-4; Simonsen, 1975, p. 92, pl. 3, figs. 6-7; Baldauf and Barron, 1980, pl. 1, figs. 1-4.

(Plate 16, Figs. 6, 9)

Actinocyclus ingens var. nodus Baldauf in Baldauf and Barron, 1980: p. 104, pl. 1, figs. 5-9.

Actinocyclus ochotensis Jousé, 1968: p. 17, fig. 2, nos. 2, 5; Sancetta, 1982 , p. 224 , pl. 1, figs. 4-6.

Actinocyclus oculatus Jousé, 1968: p. 18, fig. 2, nos. 6-7; Koizumi, 1973b, p. 831, pl. 2. figs. 8-9; Barron, 1980a, p. 681, pl. 5, figs. 1, 3.

Actinocyclus sp. A. Remarks: This peculiar Actinocyclus species is characterized by distinct star-shaped hyaline rays over the entire valve face, with varying numbers of rays. This form is found rarely in the lower Miocene Thalassiosira fraga Zone in Hole 439 and occurs consistently in both the same zone recognized in eastern Hokkaido (Akiba, unpublished data) and in a similar horizon of Kamchatka (Dolmatova, personal communication, 1979). (Plate 16, Fig. 8)

Asterolampra acutiloba Forti in Tempère and Peragallo, 1912; Forti, 1913, p. 1564, pl. 3, figs. 1, 5, 6, 9; Schrader, 1974a, pl. 9, figs. 7-8; Barron, 1980a, pl. 3, fig. 9.

(Plate 15, Fig. 8)

Asterolampra marylandica Ehrenberg, 1845; Hustedt, 1929, Kieselalg., I, p. 485, figs. 270-271; Schrader, 1974a, pl. 8, fig. 2 .

Asteromphalus arachne (Brébisson) Ralfs in Pritchard, 1861; Hustedt, 1929, Kieselalg., I, p. 493, fig. 276; Schrader, 1974a, pl. 9, fig. 11. Asteromphalus flabellatus (Brébisson) Grevielle, 1859; Hustedt, 1929, Kieselalg., I, p. 498, fig. 279; Schrader, 1974a, pl. 8, fig. 3.

Asteromphalus heptactis (Brébisson) Ralfs in Pritchard, 1861; Hustedt, 1929, Kieselalg., I, p. 494, fig. 277.

Bacterosira fragilis (Gran) Gran, 1900; Hustedt, 1929, Kieselalg., I, p. 544, fig. 310; Sheshukova-Poretzkaya, 1967, p. 202, pl. 33, figs. 3a-b; Sancetta, 1982, p. 227, pl. 2, figs. 1-4. Synonym: Coscinodiscus bathyomphalus Cleve, Hustedt, 1928, Kieselalg., I, p. 431, fig. 234, not Schrader and Fenner, 1976, p. 969, pl. 15, figs. 1, 2. Remarks: Specimens presently observed are evidently resting spores (as is the case in Sancetta, 1982) characterized by a heterovalvate nature: one valve with a very convex central part and the other valve almost flat. The latter valve looks very similar to one of Thalassiosira species.

(Plate 4, Figs. 1-4)

Bacteriastrum varians Lauder, 1864; Hustedt, 1930, Kieselalg., I, p. 617, fig. 356; Tanimura, 1981a, pl. 1, figs. 1-2a.

Coscinodiscus africanus Janisch, 1878; Hustedt, 1928, Kieselalg., I, p. 428, fig. 231; Schrader, 1974a, pl. 18, figs. 1-2.

Coscinodiscus crenulatus Grunow, 1884; Hustedt, 1928, Kieselalg., I, p. 411 , fig. 219.

(Plate 2, Fig. 5)

Coscinodiscus endoi Kanaya, 1959: p. 76, pl. 3, figs. 8-11; Koizumi, 1973b, pl. 2, fig. 10.

(Plate 2, Fig. 2)

Coscinodiscus marginatus Ehrenberg, 1843; Hustedt, 1928, Kieselalg., I, p. 416, fig. 223; Cupp, 1943, p. 55, fig. 19; Sheshukova-Poretzkaya, 1967, p. 156, pl. 11, fig. 9, pl. 17, figs. 4a-c, pl. 18, figs. 1a-2; Wornardt, 1967, figs. 27-28; Koizumi, 1968, p. 211, pl. 33, figs. 3a-b; Schrader, 1973a, pl. 20, figs. 7, 10; Akiba, 1982b, pl. 1, fig. 8; Sancetta, 1982, p. 228, pl. 2, fig. 10. Synonym: Coscinodiscus marginatus f. fossilis Jousé, 1961, p. 68, pl. 3, figs. 7-8; Koizumi, 1973b, p. 832 , pl. 3, figs. 12-14; Schrader, 1973a, p. 703 , pl. 20, figs. 12-13; Coscinodiscus tubiformis Tempère and Brun in Brun and Tempère, 1889 , p. 34 , pl. 7 , figs. 6a-b; SheshukovaPoretzkaya, 1967, p. 158, pl. 19, figs. 3a-c. Remarks: This heavily silicified, long-ranging and very populous diatom, has rather different outer and inner appearances; namely the cribrum is very delicately and beautifully ornamented in the former view, and isolated small punctae (foramen) are clearly seen in the latter view. Its outer delicate membrane (cribrum) is easily destroyed in poorly preserved specimens. Specimens with such well-preserved cribra are referred to as $C$. marginatus f. fossilis. $C$. tubiformis is anything but a small specimen of $C$. marginatus by my examination of the type material of the former species ("Calcaire de Sendai"). (Plate 1, Figs. 1-4)
Coscinodiscus nodulifer Schmidt in Schmidt et al., 1878: pl. 59, figs. 20-23; Hustedt, 1928, Kieselalg., I, p. 426, fig. 229; Tanimura, 1981a, pl. 3, figs. 3a-b, 6a-b. Remarks: Less typical form that is intermediate between this species and Coscinodiscus sp. A are counted as $C$. cf. nodulifer.

(Plate 2, Figs. 6-7, Plate 3, Fig. 6)

Coscinodiscus oculus-iridis Ehrenberg, 1839; Hustedt, 1928, Kieselalg., I, p. 454, figs. 252a-d; Sheshukova-Poretzkaya, 1967, p. 160, pl. 21, fig. 1; Sancetta, 1982, p. 229, pl. 2, fig. 11.

Coscinodiscus praenodulifer Barron, 1983: p. 511, pl. 3, figs. 9-10, pl. 6, fig. 8 .

Coscinodiscus cf. radiatus Ehrenberg.

(Plate 1, Figs. 5-6)

Coscinodiscus symbolophorus Grunow, 1884; Sheshukova-Poretzkaya, 1967, p. 167, pl. 1, fig. 3; pl. 9, fig. 1; pl. 22, figs. 3a-d; Schrader, 1973a, p. 703, pl. 22, figs. 8-9; Schrader, 1976, p. 631, pl. 7, figs. 1-3; pl. 10, figs. 1, 4, 5 as Coscinodiscus symbolophorus Group. Synonym: Coscinodiscus stellaris Roper var. symbolophorus (Grunow) Joergensen, Hustedt, 1928, Kieselalg., I, p. 396, figs. 208a-b; Koizumi, 1973b, p. 832, pl. 4, figs. 5-6.

(Plate 2, Fig. 1)

Coscinodiscus tabularis Grunow, 1884; Hustedt, 1928, Kieselalg., I, p. 427 , fig. 230a; Hustedt, 1958, p. 119, pl. 6, figs. 48-56.

Coscinodiscus tabularis var. egregius (Rattray) Hustedt, 1928: Kieselalg., I, p. 428, fig. 230b; Barron, 1980a, pl. 3, figs. 1-3; Sancetta, 1982 , p. 230 , pl. 2, fig. 13.

(Plate 2, Figs. 3-4)

Coscinodiscus wailesii Gran and Angust, 1931; Cupp, 1943, p. 58, fig. 23; Tanimura, 1981a, pl. 2, figs. 2a-b.

(Plate 2, Fig. 8)

Coscinodiscus sp. A. Remarks: This form is similar to $C$. nodulifer, but is distinguished from it by a small but conspicuous central hyaline area, which is slightly eccentric. I have an impression that this form has not been previously described yet and that it is a distinct species from $C$. nodulifer, but further studies of this form made be needed to establish it as a new taxon.

(Plate 3, Figs. 1-5)

Cosmiodiscus insignis Jousé, 1961: p. 67, pl. 2, fig. 8; SheshukovaPoretzkaya, 1967, p. 175, pl. 25, figs. 2a-c; Koizumi, 1973b, p. 832, pl. 4, figs. 7-11; Barron, 1980a, pl. 4, fig. 1.

(Plate 17, Fig. 1)

Cyclotella striata (Kützing) Grunow, 1880; Hustedt, 1928, Kieselalg., I, p. 344, figs. 176a-b; Tanimura, 1981a, pl. 5, figs. 7a-b. (Plate 4, Figs. 8-10)

Crucidenticula ikebei Akiba and Yanagisawa, this volume. Synonym: Denticula ikebei Akiba ex Barron, 1980a, p. 672, pl. 1, fig. 30, nom. invalid.

Crucidenticula kanayae Akiba and Yanagisawa, this volume. Synonym: Denticula kanayae Akiba ex Barron, 1980a, p. 672, pl. 1, figs. 2628, nom. invalid.

Crucidenticula nicobarica (Grunow) Akiba and Yanagisawa, this volume. Synonym: Denticula nicobarica Grunow, 1868, p. 97, pl. 1A, figs. 5a-b; Denticulopsis nicobarica (Grunow) Simonsen, 1979, p. 65 .

(Plate 26, Figs. 1-4)

Crucidenticula paranicobarica Akiba and Yanagisawa, this volume. (Plate 26, Fig. 7)

Crucidenticula punctata (Schrader) Akiba and Yanagisawa, this volume. Synonym: Denticula punctata Schrader, 1973a, p. 705, pl. 1, figs. 25-30, not figs. 16-17; Denticulopsis punctata (Schrader) Simonsen, 1979, p. 65; Denticula punctata f. hustedtii Schrader, 1973a, p. 705, pl. 1, figs. 23, 24; Denticulopsis punctata f. hustedtii (Schrader) Simonsen, 1979, p. 65.

Denticulopsis dimorpha (Schrader) Simonsen emend. Akiba and Yanagisawa, this volume. Synonym: Denticula dimorpha Schrader, $1973 a$, p. 704 , in part, pl. 1, figs. $37-46$.

(Plate 26, Fig. 9; Plate 27, Figs. 1-13)

Denticulopsis hustedtii (Simonsen and Kanaya) Simonsen, 1979: p. 64. Synonym: Denticula hustedtii Simonsen and Kanaya, 1961, p. 501, pl. 1, figs. 19-25. Remarks: In most occurrence charts in the text, this species and $D$. katayamae Maruyama are put together under the name $D$. hustedtii s.l., because generally they can be differenti- 
ated only under higher magnifications, and their girdle views are indistinguishable. (Plate 28, Figs. 5-18)

Denticulopsis hyalina (Schrader) Simonsen, 1979: p. 64. Synonym: Denticula hyalina Schrader, 1973a, p. 704, pl. 1, figs. 12-22. (Plate 26, Figs. 20-25)

Denticulopsis katayamae Maruyama, 1984: p. 58, pl. 12, figs. 1-6; pl. 17, figs. 1-32. Remarks: This species is quite similar to $D$. hustedtii, but is distinguished from the latter by a hyaline valve face. For more detail, see Akiba and Yanagisawa, this volume. (Plate 28, Figs. 1-4)

Denticulopsis lauta (Bailey) Simonsen, 1979: p. 64. Synonym: Denticula ? lauta Bailey, 1854, p. 9, figs. 1-2; Denticula lauta Bailey, Simonsen and Kanaya, 1961, p. 500, in part, pl. 1, figs. 1-5, not figs. 6-10. (Plate 26, Figs. 15-19)

Denticulopsis miocenica (Schrader) Simonsen, 1979: p. 65. Synonym: Denticula miocenica Schrader, 1973a, p. 705, pl. 2, figs. 26-28. (Plate 26, Figs. 26-27)

Denticulopsis praedimorpha Barron ex Akiba, 1982: Akiba, 1982b, p. 46, text-fig. 4, pl. 11, figs. 9a-27b. Synonym: Denticula lauta Bailey, Simonsen and Kanaya, 1961, p. 500, in part, pl. 1, figs. 6-10, not $1-5$.

(Plate 26, Fig. 8; Plate 27, Figs. 14-26)

Ditylum brightwelli (West) Grunow, 1881; Hustedt, 1930, Kieselalg., I, p. 784 , figs. $457-459$.

Endictya cf. oceanica Ehrenberg, 1845; Hustedt, 1930, Kieselalg., I, p. 297 , fig. 136.

Ethmodiscus rex (Rattray) Hendey in Wiseman and Hendey, 1953: p. 51, pl. 1, figs. 1-6; pl. 2, figs. 1-3; Tanimura, 1981b, pl. 1, figs. 1-3.

Eucampia zoodiacus Ehrenberg, 1839; Hustedt, 1930, Kieselalg., I, p. 772 , fig. 451 .

Goniothecium rogersii Ehrenberg, 1841; Hanna, 1932, p. 192, pl. 11, figs. 4-6; Wornardt, 1972, pl. 3, fig. 6.

Hemiaulus bipons (Ehrenberg) Grunow in Van Heurck, 1882; Lohman, 1948, p. 177, pl. 10, fig. 7; Akiba et al., 1982, pl. 2, fig. 30.

Hemiaulus cf. polymorphus Grunow, 1884; Schrader, 1973a, p. 705, pl. 13, figs. 4-7. Remarks: This form is similar to $H$. polymorphus, but lacks pesudosepta. Comparison of this form with $\mathrm{Eu}$ campia balaustium Castracane is also needed.

Hemidiscus cuneiformis Wallich, 1860; Hustedt, 1930, Kieselalg., I, p. 904, fig. 542; Schrader, 1973a, pl. 24, fig. 14. Remarks: Occurrence charts include $H$. simplicissimus Hanna and Grant (1926, p. 147 , pl. 16, fig. 13) in this species. (Plate 16, Figs. 3-4)

Hemidiscus ovalis Lohman, 1938: p. 91, pl. 22, fig. 9; Barron, 1981, pl. 5 , fig. 8.

(Plate 16, Figs. 1-2)

Katahiraia aspera Komura, 1976: p. 385, text-fig. 5, pl. 41, figs. 1-5.

Kisseleviella carina Sheshukova-Poretzkaya, 1962: p. 207, figs. 2a-c, text-figs. 1a-b; 1967 , p. 236 , pl. 40 , figs. $6 a-c$, pl. 41 , figs. 5a-c; Koizumi, 1973b, p. 833, pl. 7, figs. 3-4. Remarks. Specimens found in present material are resting spores of the species. Its vegetative cells have been recognized only in very well-preserved samples from specific localities. (For more detail, see Akiba and Yanagisawa, this volume.) (Plate 19, Figs. 17-18)

Lithodesmium reynoldsii Barron, 1976: p. 53, pl. 1, figs. 17-18; 1980a, pl. 4 , fig. 10. (Plate 17, Fig. 12)

Medialia splendida Sheshukova-Poretzkaya, 1962: p. 210, fig. 2, textfig. 5 ; 1967 , p. 307 , pl. 47 , fig. 14 , pl. 48 , fig. 8 ; Koizumi, 1973b, p. 833 , pl. 7 , figs. $5-6$.

Melosira albicans Sheshukova-Poretzkaya, 1964: p. 69, fig. 1, nos. 1-2; pl. 1, fig. 3; 1967, p. 124, pl. 10, figs. 2a-b; pl. 11, figs. 1a-b; Koizumi, 1972, p. 351 , pl. 43, figs. 1-2.

(Plate 4, Figs. 11-12)

Neobrunia mirabilis (Brun) Kuntze, 1898; Hendey, 1981, p. 11, pl. 1, figs. 1-3; pl. 2, figs. 4-7; pl. 3, figs. 10-13. Synonym: Brightwellia (?) mirabilis Brun in Brun and Tempére, 1889, p. 27, pl. 8, fig. 1; Bruniopsis mirabilis (Brun) Karsten, Schrader, 1976, p. 630, pl. 14, fig. 1 .
Neodenticula kamtschatica (Zabelina) Akiba and Yanagisawa, this volume. Synonym: Denticula kamtschatica Zabelina, 1934, p. 16, figs. 7-9; Simonsen and Kanaya, 1961, p. 503, pl. 1, figs. 14-18; Denticulopsis kamtschatica (Zabelina) Simonsen, 1979, p. 64. (Plate 25, Figs. 7-27)

Neodenticula koizumii Akiba and Yanagisawa, this volume. Synonym: Denticula seminae Simonsen and Kanaya, Koizumi, 1973b, p. 832, pl. 5, figs. 5-9, not figs. 1-4; not Denticula seminae f. fossilis Koizumi ex Schrader, 1973a, p. 705, pl. 5, figs. 30, 37-38.

Neodenticula seminae (Simonsen and Kanaya) Akiba and Yanagisawa, this volume. Synonym: Denticula marina Semina, 1956, p. 82, figs. 1-2b, nom. invalid; Denticula seminae Simonsen and Kanaya, 1961, p. 503, pl. 1, figs. 26-32; Denticulopsis seminae (Simonsen and Kanaya) Simonsen, 1979, p. 65.

(Plate 25, Figs. 28-32)

Nitzschia challengeri Schrader, 1973: 1973a, p. 707, pl. 5, figs. 10-14, 34 (?); Barron, 1980a, pl. 2, fig. 10; 1981, pl. 4, fig. 19 (?). [Plate 24, Fig. 12 (?)]

Nitzschia cylindrus (Grunow) Hasle, 1972: p. 115; Sancetta, 1982, p. 232, pl. 3, figs. 6-7. Synonym: Fragilaria cylindrus Grunow, Hustedt, 1931, Kieselalg., II, p. 152, fig. 665; Fragilariopsis cylindrus (Grunow) Helmck and Krieger, Hustedt, 1958, p. 162, figs. 145-146; Koizumi, 1973b, p. 832, pl. 7, figs. 1-2.

Nitzschia cf. extincta Kozurenko and Sheshukova-Poretzkaya sensu Koizumi, 1972: p. 351, pl. 42, figs. 10a-11b.

(Plate 24, Figs. 14-16)

Nitzschia fossilis (Frenguelli) emend. Kanaya ex Schrader, 1973: 1973a, p. 707, pl. 4, figs. 4-5, 9-11, 24-25; Koizumi, 1972, p. 352, pl. 42, figs. 14a-15c; Koizumi and Kanaya, 1976, p. 155, pl. 1, figs. 11-14. Synonym: Fragilariopsis pliocena (Brun) Sheshukova-Poretzkaya, Kanaya, 1971, p. 556, pl. 40.3, figs. 7a-8b; not Sheshukova-Poretzkaya, 1967 , pl. 48 , fig. 13.

[Plate 22, Figs. 1-2, 3(?)]

Nitzschia grunowii Hasle, 1972: p. 115; Sancetta, 1982, p. 233, pl. 3, figs. 8-10. Synonym: Fragilaria oceanica Cleve, Hustedt, 1931, Kieselalg., II, p. 148, fig. 662; Fragilariopsis oceanica (Cleve) Hasle, 1965b, pl. 1, figs. 15-19; pl. 2, figs. 6-9; pl. 3, figs. 1-2; pl. 16, figs. 1-2.

(Plate 24, Figs. 19-21)

Nitzschia heteropolica Schrader, 1973: 1973a, p. 707, pl. 26, figs. 1-2; not Barron, 1980a, pl. 2, fig. 7; pl. 4, fig. 9.

(Plate 23, Fig. 3)

Nitzschia interruptestriata Simonsen, 1974: p. 52, pl. 36, figs. 9-11; pl. 37, figs. 1a-7; pl. 38, figs. 1-7; Tanimura, 1981a, pl. 7, figs. 5a-b. Synonym: Nitzschia interrupta Heiden in Heiden and Kolbe, 1928, p. 665 , pl. 7, fig. 150. Remarks: Nitzschia capuluspalae Simonsen $(1974$, p. 50 , pl. 35, figs. 16-23) was operationally included in this species in occurrence charts.

(Plate 24, Figs. 2-3)

Nitzschia jouseae Burckle, 1972: p. 240, pl. 2, figs. 17-21; Schrader, 1974a, pl. 7, figs. 14-23; Barron, 1980a, pl. 3, fig. 2.

[Plate 23, Figs. 4, 5(?), 11]

Nitzschia kolaczekii Grunow, 1877; Hasle, 1960, p. 24, pl. 5, figs. 50a-c; Simonsen, 1974, p. 52; Fenner et al., 1976, p. 776, pl. 3, fig. 16.

(Plate 24, Fig. 5)

Nitzschia marina Grunow in Cleve and Grunow, 1880; Schrader, 1973a, pl. 4, figs. 17-19; Simonsen, 1974, p. 53, pl. 40, fig. 4 . (Plate 22, Fig. 12)

Nitzschia miocenica Burckle, 1972: p. 240, pl. 2, figs. 10-15; Schrader, 1974a, pl. 5, figs. 10-11; Barron, 1980a, pl. 2, fig. 8; pl. 3, figs. 3-4; Koizumi, 1980, pl. 3, figs. 1-8. (Plate 23, Figs. 10, 14)

Nitzschia pliocena (Brun) Mertz, 1966: p. 30; Barron, 1980a, pl. 2, figs. 1-2 as Nitzschia pliocena (Brun) Kanaya and Koizumi. Synonym: Fragilaria pliocena Brun, 1891, p. 28, pl. 14, fig. 7. Remarks: Several distinct species under the names of either Nitzschia pliocena or Fragilariopsis pliocena (Brun) Sheshukova-Poretzkaya have been referred to by different authors. (For more detail, see Akiba and Yanagisawa, this volume.)

(Plate 23, Figs. 6-9)

Nitzschia reinholdii Kanaya ex Schrader, 1973: 1973a, p. 708, pl. 4, figs. 12-16; pl. 5, figs. 1-9; Barron, 1980a, pl. 2, fig. 11; pl. 3, fig. 1. 
Synonym: Fragilariopsis pliocena (Brun) Sheshukova-Poretzkaya, Koizumi, 1968, pl. 34, figs. 13a-16.

(Plate 22, Figs. 4-5)

Nitzschia rolandii Schrader emend. Koizumi, 1980: p. 396, pl. 2, figs. 15-20; Schrader, 1973a, p. 708, pl. 26, figs. 3-4, pl. 5, fig. 31. Synonym: Denticula seminae f. fossilis Koizumi ex Schrader, 1973a, pl. 5 , figs. $30,37-38$.

(Plate 25, Figs. 1-6)

Nitzschia cf. seriata Cleve. Remarks: The present form is similar to the species (Hasle, 1965a, p. 8, pl. 1, fig. 1; pl. 3, figs. 1-7, 10; pl. 4, figs. $1-2$; pl. 6 , fig. 2 ), but possibly also includes several closely related species that are described by Hasle (1965a) in detail. (Plate 24, Fig. 1)

Nitzschia cf. sicula (Castracane) Hustedt, 1958: p. 180, figs. 128-132; Tanimura, 1981a, pl. 7, figs. 4a-b. (Plate 24, Fig. 4)

Nitzschia suikoensis Koizumi, 1980: p. 394, pl. 1, figs. 1-6.

Nitzschia sp. 1. Remarks: This taxon evidently includes several distinct species and needs further study. It resembles the following species, but there is no precise identification at present: Nitzschia extincta Kozurenko and Sheshukova-Poretzkaya in Sheshukova-Poretzkaya 1967 , p. 307 , pl. 47 , fig. 12 ; N. invisa Schrader, 1973a, p. 708 , pl. 26, fig. 5 ; N. burckliana Schrader, 1974b, p. 546, fig. 6:29-30; $N$. kanayensis Schrader, 1974b, p. 547, fig. $66: 23,25 ; N$. riedelia Schrader, 1974b, p. 549, fig. 6:20-21; and N. grunowii Hasle, 1972, p. 115.

(Plate 24, Figs. 6-11)

Odontella aurita (Lyngbye) Agardh, 1832; Sancetta, 1982, p. 234, pl. 3 , figs. 11-12. Synonym: Biddulphia aurita (Lyngbye) Brébisson and Goedy, Hustedt, 1930, Kieselalg., I, p. 846, fig. 501; Schrader, 1973a, pl. 13, figs. 1-3; Tanimura, 1981a, pl. 1, figs. 4a-b. (Plate 17, Figs. 2-3)

Odontella sp. Remarks. Mostly only broken robust spines were encountered, but rare specimens with fragments of valves suggest that this form is close to Biddulphia longicruris Grevielle (Cupp, 1943, p. 154, fig. 111-A). Synonym: Biddulphia sp. A, Akiba et al., 1982, pl. 2, fig. 23.

Planktoniella sol (Walich) Schütt, 1893; Hustedt, 1928, Kieselalg., I, p. 465 , fig. 295 ; Hasle, 1960 , p. 11 , pl. 3 , figs. 19-20. [Plate 14, Figs. 8, 10-11(?)]

Porosira gracialis (Grunow) Joergensen, 1905; Hustedt, 1928, Kieselalg., I, p. 315, fig. 153; Koizumi, 1973b, p. 833, pl. 4, figs. 15-18; Sancetta, 1982 , p. 235 , figs. 16-18.

Pseudoeunotia doliolus (Wallich) Grunow in Van Heurck, 1880; Hustedt, 1932, Kieselalg., II, p. 258, fig. 737; Schrader, 1973a, pl. 4, figs. 1-3, 6-8, not 4-5; Koizumi and Kanaya, 1976, p. 155, pl. 1, figs. $9-10$. (Plate 22, Figs. 1-2)

Pseudopodosira elegans Sheshukova-Poretzkaya, 1964: p. 75, pl. 1, fig. 3 , pl. 2 , figs. $4-5 ; 1967$, p. 178 , pl. 24 , fig. 3 ; pl. 25 , fig. 4 ; Koizumi, 1973b, pl. 4, fig. 14. Remarks: This extinct species is possibly heterovalvate, because valves both with and without central pores are observed.

(Plate 4, Figs. 5-7)

Pseudopyxilla americana (Ehrenberg) Forti, 1909; Sheshukova-Poretzkaya, 1967 , p. 227 , pl. 39, figs. 2a-b; Schrader, 1973a, p. 708 , pl. 10, fig. 22 .

Pseudotriceratium chenevieri (Meister) Gleser, 1975; Schrader and Fenner, 1976, p. 994, pl. 11, figs. 7-9; pl. 26, fig. 5; Jousé et al., 1979, p. 51, figs. 152-153. Synonym: Triceratium chenevieri Meister, Hajós, 1976, pl. 21, figs. 9-10.

Pterotheca subulata Grunow in Van Heurck, 1880; Sheshukova-Poretzkaya, 1967, p. 230 , pl. 39, fig. 4; pl. 40, fig. 3.

Rhizosolenia alata Brightwell, 1858; Hustedt, 1929, Kieselalg., I, p. 600, fig. 345; Schrader, 1973a, pl. 10, fig. 12. (Plate 18, Fig. 6)

Rhizosolenia barboi (Brun) Tempère and Peragallo, 1908; Schrader, 1973a, pl. 24, figs. 4, 7; Barron, 1980a, pl. 2, fig. 17. Synonym: Pyxilla (Rhizosolenia ?) barboi Brun, 1894, p. 87, pl. 5, figs. 16-17, 23; Rhizosolenia curvirostris var. inermis Jousé, Koizumi, 1973b, pl. 5, figs. 32-33; Rhizosolenia curvirostria Jousé, Koizumi, 1975a, pl. 1, figs. 35-37.

(Plate 18, Fig. 2)

Rhizosolenia bergonii Peragallo, 1892; Hustedt, 1929, Kieselalg., I, p. 575 , fig. 327 ; Schrader, 1973 a, p. 709 , pl. 9 , figs. $1-5,6$ (?), not 10, 12, 22-23; pl. 10, figs. 24, 29: Tanimura, 1981a, pl. 6, fig. 12; Koizumi and Kanaya, 1976, pl. 1, figs. 20-21.

Rhizosolenia calcar-avis Schultzem, 1958; Hustedt, 1929, Kieselalg., p. 592 , fig. 339.

Rhizosolenia curvirostris Jousé, 1968: p. 19, pl. 3, fig. 2; Koizumi, 1973b, pl. 5, figs. 29-31; Barron, 1980a, pl. 2, fig. 12.

(Plate 18, Fig. 3)

Rhizosolenia hebetata (Bailey) Gran f. hiemalis Gran, 1904; Hustedt, 1929, Kieselalg., I, p. 590, figs. 337a-e; Koizumi, 1973b, pl. 5, figs. 34-35; Barron, 1980a, pl. 2, fig. 15; Tanimura, 1981a, pl. 6, figs. 11, 13. Remarks: Two morphologically distinct forms are recognized; one with a symmetric horn (Plate 18, Fig. 10) and the other with an asymmetric horn (Plate 18, Fig. 9). It has been observed that the latter occurs more abundantly than the former from the base of the Neodenticula seminae Zone (NPD12) through Recent, in several piston cores from the high-latitude area of the North Pacific (Akiba and Burckle, unpublished data). Both forms are possibly restricted to Quaternary. Similar forms found in Pliocene and Miocene sequences are tabulated as $R$. cf. hebetata f. hiemalis Gran.

(Plate 17, Figs. 10-11; Plate 18, Figs. 9-10)

Rhizosolenia hebetata f. semispina (Hensen) Gran, 1905; Hustedt, 1929, Kieselalg., I, p. 592, fig. 338. Synonym: Rhizosolenia styliformis Brightwell, Schrader, 1973a, pl. 10, figs. 1, 20-21, not 18-19; pl. 9, fig. 9. Remarks: Forms similar to this taxon but represented by much more robust specimens found in Pliocene and Miocene sequences are counted as $R$. cf. hebetata f. semispina. (Plate 18, Fig. 8)

Rhizosolenia interposita Hajós, 1976: p. 827, pl. 21, fig. 8 .

Rhizosolenia miocenica Schrader, 1973: 1973a, p. 709, pl. 10, figs. 2-6, 9-11; Barron, 1980a, pl. 4, fig. 8; Akiba et al., 1982, pl. 2, fig. 18. Synonym: Rhizosolenia sp. 2 in Sheshukova-Poretzkaya, 1967 , p. 204, pl. 33, fig. 6 .

(Plate 18, Fig. 7)

Rhizosolenia praebarboi Schrader, 1973: 1973a, p. 709, pl. 24, figs. 1-3; Barron, 1980a, pl. 2, fig. 18.

(Plate 18, Fig. 1)

Rhizosolenia setigera Brightwell, 1858; Hustedt, 1929, Kieselalg., I, p. 588, fig. 336; Tanimura, 1981a, pl. 6, fig. 14.

(Plate 18, Fig. 5)

Rhizosolenia styliformis Brightwell, 1858; Hustedt, 1929, Kieselalg., I, p. 584 , fig. 334; Cupp, 1943, p. 87, fig. 48A; Tanimura, 1981a, pl. 6 , fig. 10 . (Plate 18, Fig. 4)

Rhizosolenia sp. A. Remarks: Similar to $R$. hebetata f. hiemalis, but is distinguished from it by a somewhat twisted horn. This form is rare to frequent in the upper upper Miocene (upper part of the Thalassionema schraderi Zone through lowermost part of the Neodenticula kamtschatica Zone).

(Plate 18, Fig. 11)

Rhizosolenia sp. B. Synonym: Rhizosolenia sp. 2 in Sheshukova-Poretzkaya sensu Koizumi, 1973b, p. 833, pl. 5, figs. 40-41. Remarks: This form is similar to $R$. norwegica Schrader (in Schrader and Fenner, 1976, p. 996, pl. 9, figs. 4, 10), but it does not have an inflated valve. This taxon is generally rare in the lower Miocene (the Crucidenticula kanayae and Thalassiosira fraga zones). (Plate 17, Figs. 8-9)

Rhizosolenia spp. Remarks: Several distinct species other than those treated above are recognized, but they are difficult to define clearly at present and are classified as miscellaneous in occurrence charts. (Plate 17, Figs. 14-16)

Roperia tesselata (Roper) Grunow in Van Heurck, 1881; Hustedt, 1928, Kieselalg., I, p. 523, fig. 297; Schrader, 1973a, pl. 19, figs. 3-4, 8-9; Tanimura, 1981a, pl. 3, figs. 4a-b.

(Plate 16, Fig. 7)

Rouxia californica Peragallo in Tempère and Peragallo, 1910; Hanna, 1930, p. 186, pl. 14, figs. 6-7; Schrader, 1973a, p. 710, pl. 3, 
figs. $18-20,22,26$; Barron, 1980a, p. 672 , pl. 4, fig. 4. (Plate 21, Figs. 5-6)

Rouxia naviculoides Schrader, 1973: 1973a, p. 710, pl. 3, figs. 27-32.

Rouxia cf. peragalli Brun and Hèribaud, 1893. Remarks: This form is very close to the species (Hanna, 1930, p. 180, pl. 14, figs. 1-5) in outline, but it has dense transapical costae similar to $R$. californica. (Plate 21, Fig. 17)

Rouxia spp. Remarks. Few forms that are close to either $R$. moholensis Schrader (1974b, p. 555, Fig. 5:9; 11-12) or $R$. diploneides Schrader (1973a, p. 710, pl. 3, figs. 27-32) are recognized in the present material, but no precise identifications are possible at present for them.

(Plate 21, Fig. 10)

Rossiella tatsunokuchiensis (Koizumi) Gersonde and Schrader, 1984: p. 106. Synonyms: Rhaphoneis tatsunokuchiensis Koizumi, 1972, p. 349, pl. 42, figs. 3-4; Cussia tatsunokuchiensis (Koizumi) Schrader, 1974b, p. 543, Fig. 1:8; Koizumi, 1975b, Pl. 4, figs. 33-35; Barron, 1980a, fig. 3. Remarks: Koizumi (1972) stated that this species is distinguished from its closely related species, $R$. mediopunctata (Hajós) Gersonde and Schrader (=Rhaphoneis mediopunctata Hajós, 1968 , p. 143, pl. 41, figs. 16-27), by its smaller size. It seems to me that a more characteristic feature separating the two species is valve shape; $R$. mediopunctata is linear-lanceolate, whereas the valve of $R$. tatsunokuchiensis is linear with steeply attenuated apices. Several forms intermediate between the two species are tabulated as $R$. cf. tatsunokuchiensis.

(Plate 19, Figs. 7-12)

Rossiella praepaleacea (Schrader) Gersonde and Schrader, 1984: p. 104. Synonym: Coscinodiscus praepaleaceus Schrader, 1973a, p. 703, pl. 3, figs. 1-9; Cussia paleacea (Schrader) Schrader, 1974a, p. 914; 1974 b, p. 543, Fig. 1:8. (Plate 19, Fig. 6)

Stephanogonia hanzawae Kanaya, 1959: p. 118, pl. 11, figs. 3-7; Koizumi, 1968 , p. 217 , pl. 35 , figs. 3a-4. Remarks: Specimens with a weakly inflated mantle are referred to as $S$. cf. hanzawae.

Stephanopyxis dimorpha Schrader, 1973: 1973a, p. 711, pl. 15, figs. 9-11, 19-20; pl. 16, figs. 1-3, 8-11, pl. 24, fig. 10.

(Plate 4, Fig. 13)

Stephanopyxis spp. Remarks: Species not referable to dimorpha are assigned to this category for taxonomic refinement at some later date.

Synedra jouseana Sheshukova-Poretzkaya, 1962: p. 208, fig. 4; 1967, p. 245 , pl. 42 , figs. $4 a-b ;$ pl. 43 , figs. 12a-b; Schrader, 1973a, p. 710 , pl. 23 , figs. $21-23,25,38$; Barron, $1980 \mathrm{a}$, pl. 2, figs. 13-14 (Plate 21, Fig. 9)

Synedra jouseana f. linearis Sheshukova-Poretzkaya, 1962: p. 209, fig. 3; 1967, p. 246, pl. 42, fig. 5; pl. 43, fig. 13. Synonym: Thalassionema hirosakiensis (Kanaya) Schrader, Schrader, 1976, pl. 1, figs. 14-16; Schrader and Fenner, 1976, pl. 5, figs. 3-4, 6-7; Synedra jouseana var. 1, Barron, 1980a, p. 672 , pl. 1, fig. 33. Remarks: This form is included with the above species in occurrence charts. (Plate 21, Fig. 8)

Synedra miocenica Schrader, 1976: p. 636, pl. 1, fig. 1. (Plate 21, Fig. 7)

Thalassionema bacillaris (Heiden) Kolbe, 1955: p. 178; Hasle, and Mendiola, 1967, p. 109, figs. 1-4, 19, 22-26; Simonsen, 1974, p. 37 , pl. 24, fig. 1. Synonym: Thalassionema elegans Hustedt, 1958, p. 140 , pl. 9 , fig. 93 .

(Plate 21, Fig. 12)

Thalassionema hirosakiensis (Kanaya) Schrader, 1973: 1973a, p. 711; Akiba, 1982a, p. 49, figs. 1-5; not Schrader, 1973a, pl. 23, figs. 31-33; not 1976, pl. 1, figs. 14-16; Schrader and Fenner, 1976, pl. 5, figs. 3-4, 6-7; not Barron, 1980a, pl. 2, fig. 6; 1981, pl. 5, fig. 4. Synonym: Fragilaria hirosakiensis Kanaya, 1959, p. 104, figs. 11a14, not Hajós, 1968, pl. 44, figs. 17-19, 21-29.

(Plate 21, Figs. 1-3)

Thalassionema nitzschioides (Grunow) H. and M. Peragallo, 1901; Sancetta, 1982, pl. 4, figs. 11-13; Hustedt, 1932, Kieselalg., II, p. 245 , figs. $725 \mathrm{a}-\mathrm{c}$ as $T$. nitzschioides Grunow; Hasle and Mendiola, 1967, p. 111, figs. 5, 11-17, 27-34, 39-44 as T. nitzschioides (Grunow) Hustedt. Remarks: No attempt was made to separate several varieties of this species (see Koizumi, 1973b, p. 833). Possi- bly included here is Thalassiothrix pseudonitzschioides Schuette and Schrader (1982, p. 214 , figs. 1-30), because only by very careful observations can it be differentiated from the present form. A detailed history of the taxonomic treatments of this most common Neogene species is found in Sancetta (1982).

[Plate 21, Figs. 11, 19 (?)]

Thalassionema schraderi Akiba, 1982: 1982a, p. 50, pl. 1, figs. 6-11, 16-18. Synonym: Thalassionema hirosakiensis (Kanaya) Schrader, 1973a, pl. 23, figs. 31-33; Barron, 1980a, pl. 2, fig. 6; 1981, pl. 5, fig. 4; Thalassionema hirosakiensis (Kanaya) Schrader s.1., Akiba et al., 1982, pl. 3, figs. 77-80.

(Plate 21, Figs. 13-16)

Thalassiosira anguste-lineata (A. Schmidt) Fryxell and Hasle, 1977: p. 73, figs. 22-34. Synonym: Coscinodiscus anguste-lineata Schmidt in Schmidt et al., 1878, pl. 59, fig. 34 .

Thalassiosira antiqua (Grunow) Cleve-Euler, 1941; Cleve-Euler, 1951, p. 72 , fig. 119; Sheshukova-Poretzkaya, 1967, p. 143, pl. 14, figs. 3a-b; Koizumi, 1973b, p. 834, pl. 7, fig. 12; Schrader, 1973a, pl. 11, fig. 25; pl. 25, fig. 19; Barron, 1980a, pl. 5, fig. 5 . (Plate 12, Figs. 1, 3-4)

Thalassiosira burckliana Schrader, 1974: 1974a, p. 916, pl. 1, figs. 2126; Barron, 1980a, p. 673, pl. 3, fig. 7. Synonym: Thalassiosira sp. A, Burckle, 1972, p. 241 , pl. 1, fig. 1; Thalassiosira nativa Sheshukova-Poretzkaya, Schrader, 1973a, p. 712, pl. 11, figs. 23-24. (Plate 12, Fig. 5)

Thalassiosira brunii Akiba and Yanagisawa, this volume. Synonym: Coscinodiscus temperei var. delicata Barron, 1981, p. 528, pl. 3, figs. 1, 3-4.

Thalassiosira convexa Muchina, 1965: p. 22, pl. 11, figs. 1-2; Kobayashi et al., 1971, p. 1059, fig. 5, figs. 3a-b; Koizumi, 1972, p. 353, pl. 43, figs. 15a-b; Schrader, 1973a, pl. 2, figs. 1-5, 10-13, not Schrader, 1973a, pl. 11, figs. 37-38; Koizumi, 1973b, pl. 7, figs. 13-15. Synonym: Thalassiosira undulosa (Mann) Sheshukova-Poretzkaya, Koizumi, 1968, pl. 35, figs. 26a-b. Remarks: No attempt to distinguish the species from $T$. convexa var. aspinosa Schrader (1974a, p. 916, pl. 2, figs. 8-9, 13a-21) was made at present. (Plate 8, Fig. 1)

Thalassiosira cf. decipiens (Grunow) Joergensen. Remarks: This form is very close to the species figured by Sancetta $(1982$, p. 241 , pl. 5 , figs. 1-3), but definite identification was not possible, partly because her figures prepared by Nomarski are of differential interference contrasts, images that are not always clear. (Plate 15, Figs, 5-6)

Thalassiosira eccentrica (Ehrenberg) Cleve, 1904; Fryxell and Hasle, 1972 , p. 300 , pl. 1 , figs. $1 \mathrm{a}-2$; pl. 2 , figs. $3-10$; pl. 3 , figs. $11-15$; pl. 4, figs. 16-18; Simonsen, 1974, p. 9, pl. 2, figs. 1-3. Synonym: Coscinodiscus excentricus Ehrenberg, Hustedt, 1928, Kieselalg., I, p. 338, figs. 201a-b. Remarks: Present identification is tentative because of the presence of several closely related species (cf. Simonsen, 1974), which may be distinguished only by very careful observation. (Plate 14, Fig. 13)

Thalassiosira fraga Schrader in Schrader and Fenner, 1976: p. 1001, pl. 16, figs. 9-12; Barron, 1983, pl. 4, figs. 3, 5 . (Plate 8, Figs. 12-13)

Thalassiosira gravida Cleve, 1896: Hustedt, 1928, Kieselalg., I, p. 325, fig. 161; Koizumi, 1972, p. 353, pl. 43, figs. 11a-b; Koizumi, 1973a, pl. 7, figs. 19-21. Remarks: Several distinct forms are tabulated under this species, in which the size of areolae and the degree of valve convexity differ. In general, Quaternary forms are represented by specimens with finer areolae, and lower Pliocene through upper Miocene intervals by individuals with coarser areolae. Sancetta (1982, p. 240) considered resting spores of this species to be synonymous with Thalassiosira antarctica Comber, based mainly on observations by Syvertsen (1979) who discussed the morphologic relationships between vegetative cells and resting spores of both $T$. gravida and $T$, antarctica. The presence of several morphologically distinct forms of $T$. gravida may arise from morphologic differences between vegetative cells and resting spores, but may also be due to vague specific concepts of this species.

(Plate 10, Figs. 1-4) 
Thalassiosira gravida f. fossilis Jousé, 1961: p. 63, pl. 1, fig. 9; Sheshukova-Poretzkaya, 1967, p. 147, pl. 15, figs. 1a-b; Koizumi, 1972 , p. 353 , pl. 43 , fig. 10 ; 1973 b, pl. 7 , figs. $22-24$.

Thalassiosira hyalina (Grunow) Gran, 1897; Hustedt, 1928, Kieselalg., I, p. 323, fig. 159; Koizumi, 1973b, p. 834, pl. 8, figs. 1 ?, 2; Sancetta, 1982, p. 242 , pl. 5, figs. 4-5.

(Plate 5, Fig. 9)

Thalassiosira jacksonii Koizumi and Barron in Koizumi, 1980: p. 396, pl. 1, figs. 11-14; Barron, 1980a, pl. 6, figs. 2, 6, 10 (?). (Plate 11, Fig. 2)

Thalassiosira cf. jacksonii Koizumi and Barron. Remarks: Similar to the species, but is distinguished from it by lack of a central hyaline area with a pore. (Plate 11, Figs. 1, 5)

Thalassiosira leptopus (Grunow) Hasle and Fryxell, 1977: p. 20, figs. 1-14, 94-96. Synonym: Coscinodiscus lineatus Ehrenberg, $\mathrm{Hu}-$ stedt, 1928, Kieselalg., I, p. 292, fig. 204; Simonsen, 1974, p. 17, pl. 9, figs. 3-4. (Plate 14, Fig. 12)

Thalassiosira lineata Jousé, 1968: p. 13, pl. 1, figs. 1-2; Koizumi, 1975a, pl. 5, fig. 22; Simonsen, 1974, p. 9, pl. 1, figs. 4-7. (Plate 14, Figs. 7, 9)

Thalassiosira manifesta Sheshukova-Poretzkaya, 1964: p. 72, figs. 6-7; 1967 , p. 147, pl. 14, figs. 9a-b; Koizumi, 1968, pl. 35, figs. 16-17. Remarks: Several distinct forms are observed; flat valves with either broad or narrower margins, slightly convex valves with variable densities of radial punctae or fine areolae. Stratigraphic occurrences of those forms are almost identical to each other. They suggest that this species is heterovalvate and furthermore that it is represented by resting spores.

(Plate 9, Figs. 1-3)

Thalassiosira marujamica Sheshukova-Poretzkaya, 1959: p. 41, pl. 1, fig. 7. Synonym: Thalassiosira decipiens (Grunow) Joergensen ?, Sheshukova-Poretzkaya, 1967, p. 141, pl. 14, fig. 2; Thalassiosira decipiens (Grunow) Joergensen, Schrader, 1973a, pl. 11, figs. 8-9; Thalassiosira nativa Sheshukova-Poretzkaya, Koizumi, 1975a, pl. 4, figs. 21-22; Barron, 1980a, pl. 6, figs. 8-9 (?), 12; Thalassiosira borealis Koizumi, 1980, p. 395, pl. 1, figs. 7-10. Remarks: Sheshukova-Poretzkaya (1967) considered her species as a doubtful synonym of $T$. decipiens, but it is clearly differentiated from the latter by very conspicuous marginal spines. Forms with less conspicuous marginal ribs but otherwise identical to the species are counted as $T$. cf. marujamica in occurrence charts.

(Plate 13, Figs. 1-7)

Thalassiosira nidulus (Tempère and Brun) Jousé, 1961: p. 63; Koizumi, 1973b, pl. 7, fig. 25, not fig. 26; not Jousé, 1961, pl. 3, figs. 4-5. Synonym: Stephanopyxis nidulus Tempère and Brun in Brun and Tempère, 1889, p. 57, pl. 8, figs. 10a-b; Thalassiosira elegans (Brun) Jousé, 1961, p. 61, pl. 1, figs. 3-4; Thalassiosira nordenskioeldii f. fossilis Jousé, 1959, pl. 3, figs. 3-4, nomen nud. Remarks: See comments under Thalassiosira jouseae n. $\mathrm{sp}$. (Plate 6, Figs. 5-7)

Thalassiosira nordenskioeldii Cleve, 1873; Hustedt, 1928, Kieselalg., I, p. 321, fig. 157; Koizumi, 1973b, p. 834, pl. 8, fig. 4; Schrader, 1973a, pl. 14, figs. 11-12; Sancetta, 1982 , p. 242 , pl. 5, figs. 8-9. Remarks: This species is very close to Thalassiosira binata Fryxell (in Hasle and Fryxell, 1977, p. 244, figs. 24-38), but is distinguished from the latter by larger valve and smaller central areolae. In addition, the form is a cold-water species, whereas the latter is a warm-water one.

(Plate 5, Fig. 8)

Thalassiosira oestrupii (Ostenfeld) Proshkina-Labrenko, 1956; Hasle, 1960 , p. 8 , pl. 1 , figs. $5-7$; Koizumi, 1973 b, p. 834 , pl. 7, fig. 27; Simonsen, 1974, p. 10, pl. 1, figs. 3-5.

(Plate 14, Figs. 1-6)

Thalassiosira cf. praeconvexa Burckle. Synonym: Thalassiosira praeconvexa Burckle, Schrader, 1973a, pl. 11, figs. 10-15; Thalassiosira sp. 1, Barron, 1980a, p. 673, pl. 5, figs. 6-7. Remarks: Larger specimens of this species resemble T. miocenica Schrader (1974a, p. 916 , pl. 22, figs. 1-5, 11-3; Plate 8, Figs. 2-3, 4 ?), but no clear distinction between the two species is possible at present. Typical specimens of $T$. miocenica occur very sporadically in the uppermost part of the Rouxia californica Zone through the lowermost part of the Neodenticula kamtschatica Zone in Holes 584 and $438 \mathrm{~A}$, but they are not tabulated in the occurrence charts. (Plate 8, Fig. 5)

Thalassiosira punctata Jousé, 1961: p. 64, pl. 1, figs. 7-8; pl. 3, fig. 1; Sheshukova-Poretzkaya, 1967, p. 151, pl. 14, fig. 10; pl. 17, figs. 1a-b; Barron, 1980a, pl. 6, fig. 3. Remarks: Two similar but distinct forms, which have similar stratigraphic occurrences, are recognized. One is regularly larger with conspicuous and widely separated punctae, and the other smaller and with short but robust spines over the whole valve surface.

(Plate 9, Figs. 5-6)

Thalassiosira singularis Sheshukova-Poretzkaya, 1967: p. 145, pl. 14, fig. 8. Remarks: This species resembles $T$. marujamica Sheshukova-Poretzkaya, but is easily distinguished from it by several radially elongated areolae at its margin and by a lack of marginal spines. This species apparently has not been reported again since it was originally described. It is quite useful biostratigraphically, restricted almost entirely to the uppermost upper Miocene Rouxia californica Zone.

(Plate 12, Figs. 6-8)

Thalassiosira temperei (Brun) Akiba and Yanagisawa, this volume. Synonym: Coscinodiscus temperei Brun in Brun and Tempère, 1889, p. 33 , pl. 8 , fig. 2 .

(Plate 7, Fig. 4)

Thalassiosira tertiaria Sheshukova-Poretzkaya, 1967: p. 148, pl. 15, fig. 2 .

Thalassiosira trifulta Fryxell in Fryxell and Hasle, 1979: p. 16, pls. 1-5, figs. 1-24; Sancetta, 1982, p. 244, pl. 5, figs. 10-12. Synonym: Coscinodiscus excentricus Ehrenberg, Koizumi, 1973b, pl. 2, figs. 11-12; Coscinodiscus excentricus var. jousei Kanaya, Koizumi, 1973b, p. 832, pl. 3, figs. 1-6; Coscinodiscus excentricus var. leasareolatus Kanaya, Koizumi, 1973b, p. 832, pl. 3, figs. 7-11. (Plate 10, Figs. 5-7)

Thalassiosira undulosa (Mann) Sheshukova-Poretzkaya, 1967: p. 148, pl. 16, figs. 1a-c; Koizumi, 1973 b, p. 834, pl. 8, figs. 5-6; not Koizumi, 1968, pl. 35, figs. 26a-b.

(Plate 9, Fig. 4)

Thalassiosira zabelinae Jousé, 1961: p. 66, pl. 2, figs. 1-7; Sheshukova-Poretzkaya, 1967 , p. 149, pl. 16, figs. 2a-d; Koizumi, 1973b, p. 834 , pl. 8 , figs. 10 (?), 11-12; Barron, 1980a, pl. 6, fig. 7. (Plate 8, Fig. 11)

Thalassiosira aff. zabelinae Jousé. Synonym: Thalassiosira convexa Muchina, Koizumi, 1973b, pl. 7, figs. 13-15; 1975a, pl. 4, figs. 19-20; Thalassiosira convexa ? var. 1 , Barron, 1980a, p. 673, pl. 5, fig. 14; pl. 6, fig. 16. Remarks: This form resembles Thalassiosira spinosa Schrader (1976, p. 636, pl. 6, figs. 5-7) described from the lower Miocene of the Southern Ocean. It is common in the lower part of the Neodenticula kamtschatica Zone (uppermost upper Miocene through lower Pliocene) in Hole 183 and is also rarely observed in the same horizons of Holes $438 \mathrm{~A}$ and 584 . The quite different stratigraphic occurrences of the two forms make positive identification impossible.

(Plate 8, Figs. 6-7, 9-10)

Thalassiosira yabei (Kanaya) Akiba and Yanagisawa, this volume. Synonym: Coscinodiscus yabei Kanaya, p. 86, pl. 5, figs. 6-9.

(Plate 7, Figs. 5-6)

Thalassiosira spp. (plicate). Remarks: Species close to both the above species and Thalassiosira grunowii Akiba and Yanagisawa (this volume) but unsuccessfully identified are counted under this name.

Thalassiosira sp. A. Synonym: Thalassiosira oestrupii (Ostenfeld) Proshkina-Lavrenko, Koizumi, 1975a, pl. 5, fig. 4. Remarks: Similar to Thalassiosira trifulta Fryxell, but is distinguished from it by generally smaller size $(21-30 \mu \mathrm{m})$, fewer number of central pores (1-2), and isolated areolae in the center. It is common and restricted to the middle part of the lower Pliocene Neodenticula kamtschatica Zone. (no illustration)

Thalassiosira sp. B. Synonym: Thalassiosira sp., Akiba et al., 1982, pl. 2, figs. 26-27. (Plate 11, Figs. 6, 9)

Thalassiosira spp. Remarks: Many species of Thalassiosira cannot be identified precisely at present, especially in the lower Pliocene and Quaternary sequences of the present material. They need further 
detailed studies, including scanning electron microscopy. Some of them are illustrated, but they are not tabulated specifically in occurrence charts, nor are they described.

(Plate 11, Figs. 3-4, 7-8; Plate 12, Fig. 2; Plate 15, Fig. 7)

Thalassiothrix longissima Cleve and Grunow, 1880: Hustedt, 1932, Kieselalg., II, p. 247, fig. 726; Cupp, 1943, p. 184, fig. 134; Schrader, 1973a, pl. 23, figs. 7, 17-18.

(Plate 21, Fig. 18)

Thalassiothrix cf. vanhoeffenii Heiden. Remarks: Only short fragments are observed. Although it resembles $T$. vanhoeffenii (Simonsen, 1974 , p. 38 , pl. 25 , figs. 1-3), the present form appears to have finer marginal striae.

Triceratium condecorum Brightwell, 1853; Hanna, 1932, p. 221, pl. 17, figs. 1, 3; Schrader, 1973a, pl. 12, fig. 9. Synonym: Triceratium sp. $\alpha$, Kanaya, 1959, p. 101, pl. 9, figs. 5a-b.

Yoshidaia sp. Remarks: The genus Yoshidaia Komura (1976, p. 389) is similar to Denticulopsis Simonsen emend. Akiba and Yanagisawa (this volume) except that the former has raphe on the midline of the valve face.

\section{Marine Tychopelagic and Benthic Diatoms}

Achnanthes groenlandica (Cleve) Grunow, 1880; Hustedt, 1933, Kieselalg., II, p. 421 , fig. 874. (Plate 30, Figs. 9-10)

Actinocyclus octonarius Ehrenberg, 1838; Hendey, 1964, p. 83, pl. 24, fig. 3; Andrews, 1976, p. 14, pl. 3, fig. 7. Synonym: Actinocyclus ehrenbergii Ralfs, Hustedt, 1929, Kieselalg., I, p. 525, fig. 298.

Actinocyclus tenellus (Brébisson) Andrews, 1976: p. 14, pl. 3, figs. 8-9. Synonym: Actinocyclus ehrenbergii var. tenella (Brébisson) $\mathrm{Hu}-$ stedt, 1928, Kieselag., I, p. 530, fig. 302.

(Plate 29, Fig. 3)

Actinoptychus senarius (Ehrenberg) Ehrenberg, 1843; Hendey, 1964, p. 95, pl. 23, figs. 1-2; Sancetta, 1982, p. 225, pl. 1, fig. 7. Synonym: Actinoptychus undulatus (Bailey) Ralfs, Hustedt, 1929, Kieselalg., I, p. 475, fig. 264.

(Plate 29, Fig. 2)

Actinoptychus splendens (Shädbolt) Ralfs in Pritschard, 1861; Hustedt, 1929, Kieselalg., I, p. 478, fig. 265.

Actinoptychus vulgaris Schumann, 1867; Sheshukova-Poretzkaya, 1967, p. 187, pl. 28, figs. 2a-d; Sancetta, 1982, p. 225, pl. 1, fig. 8. (Plate 29, Fig. 1)

Amphora costata Smith, 1853; Cleve-Euler, 1953, p. 99, fig. 690; Sheshukova-Poretzkaya, 1967, p. 297, pl. 47, fig. 6; pl. 48, fig. 1. (Plate 30, Fig. 7)

Bacillaria paradoxa Gmelin, 1788; Hustedt, 1930, Bacill., p. 396, figs. 755a-b; Simonsen, 1974, p. 49. Synonym: Bacillaria paxillifer (Müller) Hendey, 1964, p. 274, pl. 21, fig. 5.

Clavicula polymorpha Grunow and Pantocsek in Pantocsek, 1930; Sheshukova-Poretzkaya, 1967 , p. 246 , pl. 42 , fig. 6; Koizumi, 1968 , p. 210 , pl. 32, fig. 20.

Cocconeis antiqua Tempère and Brun in Brun and Tempère, 1889: p. 32, pl. 8, fig. 5; Kanaya, 1959, p. 107, pl. 10, figs. 1-2; Sheshukova-Poretzkaya, 1967 , p. 269 , pl. 45 , fig. 1.

(Plate 30, Fig. 6)

Cocconeis californica Grunow, 1881; Hustedt, 1933, Kieselalg., II, p. 343, fig. 796; Sheshukova-Poretzkaya, 1967, p. 277, pl. 43, fig. 11.

Cocconeis costata Gregory, 1855; Hustedt, 1933, Kieselalg., II, p. 332, fig. 785; Sheshukova-Poretzkaya, 1967, p. 262, pl. 44, figs. 4a-c. (Plate 30, Fig. 1)

Cocconeis scutellum Ehrenberg, 1938; Hustedt, 1933, Kieselalg., II, p. 337 , fig. 790 ; Hendey, 1964 , p. 180 , pl. 27 , fig. 8 . (Plate 30, Figs. 3, 11)

Cocconeis cf. scutellum Ehrenberg.

(Plate 30, Fig. 2)

Cocconeis vitrea Brun, 1891: p. 19, pl. 18, fig. 2; Kanaya, 1959, p. 110, pl. 10 , fig. 6 .

Cymatosira debyi Tempère and Brun in Brun and Tempère, 1889: p. 36, pl. 7, figs. 18a-b; Sheshukova-Poretzkaya, 1967, p. 237, pl. 40, fig. 7 , pl. 41 , fig. 6 . (Plate 19, Figs. 19-20)

Delphineis cf. angustata (Pantocsek) Andrews. Remarks: Several distinct but nondifferentiated species of Delphineis are tabulated un- der this name. Most specimens resemble $D$. angustata (Pantocsek) Andrews (Andrews, 1977, p. 250, pl. 1, figs. 1-4; pl. 2, figs. 2122; pl. 3, figs. 29-30), but others resemble Rhaphoneis sachaliensis Sheshukova-Poretzkaya (1967, p. 242, pl. 42, fig. 2) and Rhaphoneis ischaboensis (Grunow) Mertz (1963, p. 26, pl. 5, figs. 49-51). Both Rhaphoneis species might be members of Delphineis species, but new combinations are not attempted because the two species are not precisely identified in the present material. Short and elliptical forms are separately tabulated as $R$. cf. ischaboensis (short). It is restricted to the upper part of the Neodenticula kamtschatica Zone of Hole 584 .

(Plate 20, Figs. 4-11, 18)

Delphineis kippae Sancetta, 1982: p. 230, pl. 2, figs. 14-16. (Plate 20, Fig. 1)

Delphiensis penelliptica Andrews, 1977: p. 253, pl. 1, figs. 16-20, pl. 2, figs. 27-28, pl. 4, figs. 35-36; 1978, p. 394, pl. 5, figs. 15-17; pl. 8 , fig. 8 .

Delphineis surirella (Ehrenberg) Andrews, 1981: p. 81, pl. 1, figs. 1-5; pl. 2, figs. 6-7. Synonym: Rhaphoneis surirella (Ehrenberg) Grunow, Hustedt, 1931, Kieselalg., II, p. 173, figs. 679a-c. Remarks: Rhaphoneis surirella var. australis Petit (Hustedt, 1931, p. 174, fig. 679d) is included in this species, but the variety occurs only in the Nankai Trough and not in the Japan Trench. (Plate 20, Figs. 2-3)

Delphineis cf. surirella (Ehrenberg) Andrews. Remarks: Similar to but distinguished from the species by very delicate transapical striae.

Diploneis bombus Ehrenberg, 1844; Hustedt, 1937, Kieselalg., II, p. 704, figs. 1086a-c; Tanimura, 1981a, pl. 6, figs. 2a-b, 7a-b. [Plate 30, Figs. 5 (?), 12]

Diploneis smithii (Brébisson) Cleve, 1894; Hustedt, 1937, Kieselalg., II, p. 647, fig. 1051; Tanimura, 1981a, pl. 6, fig. 3. (Plate 30, Fig. 8)

Grammatophora spp. Remarks: The following species are recognized, but their occurrences are not specifically tabulated because they occur very sporadically; G. arcuata Ehrenberg (Hustedt, 1937, Kieselalg., II, p. 42, figs. 567a-c); G. angulosa Ehrenberg (Hustedt, 1937, Kieselalg., II, p. 39, figs. 564a-k); G. hamulifera Kützing (Hustedt, 1937, Kieselalg., II, p. 40, figs. 566a-g); and G. oceanica (Ehrenberg) Grunow (Hustedt, 1937, Kieselalg., II, p. 45, fig. 573). (Plate 29, Figs. 10-12, 16-17)

Hyalodiscus obsoletus Sheshukova-Poretzkaya, 1959; Sheshukova-Poretzkaya, 1967, p. 131, pl. 12, fig. 2. Remarks: The occurrence of this species is similar to such species as Melosira sol and Paralia sulcata, but it never occurs abundantly in any horizon, which is an indication that this extinct species may be benthic. (Plate 29, Fig. 15)

Nitzschia constricta (Kützing) Ralfs in Pritchard, 1861; Tanimura, 1981a, pl. 7, fig. 8.

Paralia sulcata (Ehrenberg) Cleve, 1873; Hendey, 1964, p. 73, pl. 23, fig. 5; Sancetta, 1982, p. 235, pl. 3, figs. 13-15. Synonym: Melosira sulcata (Ehrenberg) Kützing, Hustedt, 1928, Kieselalg., I, p. 276, figs. 118-119; Tanimura, 1981a, pl. 4, fig. 6. (Plate 29, Figs. 4-5)

Plagiogramma stuarophorum (Gregory) Heiberg, 1863; Hustedt, 1931, Kieselalg., II, p. 110, fig. 635. Remarks: Its occurrence was not tabulated, because it occurs very sporadically. (Plate 30, Fig. 12)

Podosira stelligera (Bailey) Mann, 1907; Hustedt, 1928, Kieselalg., I, p. 286, fig. 128.

Pseudodimerogramma elegans Schrader in Schrader and Fenner, 1976, p. 993, pl. 3, fig. 14.

Rhabdonema japonicum Tempère and Brun in Brun and Tempère, 1889: p. 53, pl. 1, fig. 6; Sheshukova-Poretzkaya, 1967, p. 258, pl. 43 , fig. 14; pl. 44 , figs. 1a-d; Schrader, 1973a, pl. 12, fig. 10 .

Rhaphoneis amphiceros Ehrenberg, 1884; Hustedt, 1931, Kieselalg., II, p. 174, fig. 680 .

(Plate 20, Fig. 19)

Rhaphoneis miocenica Schrader, 1973: 1973a, p. 709, pl. 25, figs. 1, 11; Akiba et al., 1982, pl. 3, fig. 85. Synonym: Rhaphoneis amphiceros Ehrenberg, Hanna, 1932, p. 211, pl. 15, figs. 3-5.

Sawamuraia biseriata Komura, 1976: p. 382, text-fig. 2, pl. 40, fig. 1 .

Stictodiscus californicus Grevielle, 1861: p. 79, pl. 10, fig. 1; Wornardt, 1967, p. 38 , figs. 54-55. 
Trachyenis aspera (Ehrenberg) Cleve, 1894; Hendey, 1964, p. 236 , pl. 29, fig. 13.

Triceratium arcticum Brightwell, 1853; Hustedt, 1930, Kieselalg., I, p. 816 , fig. 479 ; Sheshukova-Poretzkaya, 1967 , p. 211 , pl. 24 , fig. 7 , pl. 34 , figs. $4 a-b$.

Triceratium alternans Bailey, 1851; Hustedt, 1930, Kieselalg., I, p. 825, fig. 488; Barron, 1980b, pl. 10, figs. 11-12.

(Plate 29, Figs. 13-14)

Trochosira concava Sheshukova-Poretzkaya, 1967: p. 138, pl. 11, figs. 7a-b; pl. 13, fig. 3; Schrader, 1973a, pl. 12, figs. 13-14. Genus et species indet. sp. 1. Remarks: This form is similar to either Nitzschia grunowii Hasle or Synedra tabulata (Agard) Kützing (Hustedt, 1932, Kieselalg., II, p. 218, figs. 710a-n), but no precise identification is possible.

(Plate 24, Figs. 17-18)

Genus et species indet. sp. 1. Remarks: This form is similar to either Nitzschia grunowii Hasle or Synedra tabulata (Agard) Kützing (Hustedt, 1932, Kieselalg., II, p. 218, figs. 710a-n), but no precise identification is possible.

(Plate 24, Figs. 17-18)

Genus et species indet. sp. 2. Remarks: This peculiar diatom might be a member of either Odontella or Hemiaulus, but no similar species are found in the literature.

(Plate 17, Fig. 7)

\section{Nonmarine Diatoms}

In most cases only generic distinctions were made for those nonmarine diatoms encountered in the present samples. Several species are specifically identified and are tabulated in occurrence charts and can be referred to in either Hustedt (1930) or Koizumi (1975a). Only the following three taxa are discussed below because of their taxonomic and paleoceanographic interest.

Aulacosira granulata (Ehrenberg) Simonsen s.l.; Simonsen, 1979, p. 58. Synonym: Melosira granulata (Ehrenberg) Ralfs in Pritchard, Hustedt, 1927, Kieselalg., I, p. 248, figs. 104a-e. Remarks: We have made no comparisons of the present form with its $\sim 60$ related taxa (cf. Simonsen, 1979, p. 55-63). As stated in the text, this species occurs very abundantly in the lower Miocene Thalassiosira fraga Zone recognized in Hole 439, which implies a strong influx of nonmarine water at this horizon or possibly a shallower environment. It is represented by very robust valves.

(Plate 29, Figs. 6-9)

Aulacosira sp. 1. Remarks: This form is similar to A. granulata but is represented by an elliptical valve and also a transapically elongated foramen in the center of valve face. It is rarely found associated with the $A$. granulata in Hole 439 , but never occurs in the younger horizons of the DSDP holes described in this chapter. Interestingly, the fresh water diatomite found in the Japan Sea also contained this form (Burckle and Akiba, 1978).

(no illustration)

Thalassiosira bramaputae (Ehrenberg) Hakansson and Locker, 1981: p. 125 , pl. 1 , fig. 5 ; pl. 6 , figs. $34-37$; pl. 12, figs. 69-74. Synonym: Coscinodiscus lacustris Grunow, Hustedt, 1928, Kieselalg., I, p. 432, fig. 235; Thalassiosira lacustris (Grunow) Hasle in Hasle and Fryxell, 1977, p. 40; not Sancetta, 1982, p. 243, pl. 5, figs. 6-7. Remarks: See comment under Thalassiosira sancettae $\mathrm{n} . \mathrm{sp}$. (no illustration)

\section{ACKNOWLEDGMENTS}

I am very grateful to the Japan Petroleum Exploration Co., Ltd., for allowing me to participate in the Leg 87 cruise of the Glomar Challenger, to Dan Karig and to Hideo Kagami, the co-chiefs of Leg 87 , for making samples available for this study, and the entire Leg 87 crew for the rewarding experience aboard the Glomar Challenger. Tsunemasa Saito and John Barron kindly and carefully reviewed the manuscript and gave me many helpful suggestions. Discussions with Nobuaki Niitsuma and John Barron helped in making age controls of the diatom zones in this chapter. Taxonomic comments on some of the new species in this chapter were kindly made by Reimer Simonsen, George Andrews, Constance Sancetta, and Itaru Koizumi. I also wish to thank those who provided the various samples used in this chapter, especially Itaru Koizumi for DSDP Leg 19; John Barron for Leg 57, Hole 438A, and the Newport Beach Section; the National Science Foundation for Leg 57, Holes 438A and 439; Olivier Monthoux for a
Japanese classic diatom sample, "Calcaire de Sendai"; and Toru Yamanoi for the Sado Section. Kantaro Fujioka and Kikue Gunji helped in various aspects of the manuscript preparation, including tables and figures. Constant encouragement was given to me during the course of this study by Seijuro Maiya and the staff of the Micropaleontological Section of the Central Technical Laboratory of JAPEX.

\section{REFERENCES}

Akiba, F., 1977. Denticula kanayae n. sp. and the diatom biostratigraphic significance of the Denticula kanayae Zone. Bull. Tech. Lab. JAPEX, 20(3\&4):126-142. (In Japanese)

1979. The morphologies of Denticula dimorpha and its related species, and the Neogene diatom biostratigraphy of Japan. Bull. Tech. Lab. JAPEX, 22(3):9-50. (In Japanese)

1980. A lower Miocene diatom flora from the Boso Peninsula, Japan, and the resting spore formation of an extinct diatom, Kisseleviella carina Sheshukova-Poretzkaya. Bull. Tech. Lab. JAPEX, 23(2):81-100.

1982a. Taxonomy and biostratigraphic significance of a new diatom, Thalassionema schraderi. Bacillaria, 5:43-61.

, 1982b. Late Quaternary diatom biostratigraphy of the Bellingshausen Sea, Antarctic Ocean. Rep. Tech. Res. Cent. JNOC, 16:31-74.

Akiba, F., and Ichinoseki, T., 1983. The Neogene micro- and chronostratigraphies in Hokkaido-special reference to those of the southwestern part of the Kuchiro Coal Field Area, eastern Hokkaido, Japan. J. Jpn. Assoc. Pet. Technol., 48(1):49-61. (In Japanese with English abstract)

Akiba, F., Yanagisawa, Y., and Ishii, T., 1982. Neogene diatom biostratigraphy of the Matsushima Area and its environs, Miyagi Prefecture, northeast Japan. Bull. Geol. Surv. Jpn., 33(5):215-239. (In Japanese with English abstract)

Andrews, G. W., 1976. Miocene marine diatoms from the Choptank Formation, Calvert County, Maryland. U.S. Geol. Surv. Prof. Pap., 910.

1977. Morphology and stratigraphic significance of Delphineis, a new marine diatom genus. Nova Hedwigia (Beih.), 54: 243-260.

1978. Marine diatom sequence in Miocene strata of the Chesapeake Bay region, Maryland. Micropaleontology, 24(4):371406.

1981. Revision of the diatom genus Delphineis and morphology of Delphineis surirella (Ehrenberg) G. W. Andrews, n. comb. In Ross, R. (Ed.), Proc. Sixth Symp. on Recent and Fossil Diatoms: Koenigstein (Otto Koeltz Sci. Publ.), pp. 81-92.

Bailey, J. W., 1854. Notes on new American species and localities of microscopical organisms. I. Fossil marine Diatomaceae in California. Smithson. Contrib. Knowl., 7(3):1-16.

Baldauf, J. G., and Barron, J. A., 1980. Actinocyclus ingens var. nodus: a new stratigraphically useful diatom of the circum-North Pacific. Micropaleontology, 26(1):103-110.

Barron, J. A., 1976. Revised Miocene and Pliocene diatom biostratigraphy of upper Newport Bay, Newport Beach, California. Mar. Micropaleontol., 1(1):27-63.

1980a. Lower Miocene to Quaternary diatom biostratigraphy of Leg 57, off northeastern Japan, Deep Sea Drilling Project. In Scientific Party, Init. Repts. DSDP, 56, 57, Pt. 2: Washington (U.S. Govt. Printing Office); 641-685.

1980b. Upper Pliocene and Quaternary diatom biostratigraphy of the Deep Sea Drilling Project Leg 54, tropical eastern Pacific. In Rosendahl, B. R., Hekinian, R., et al., Init. Repts. DSDP, 54: Washington (U.S. Govt. Printing Office), 455-486.

1981. Late Cenozoic diatom biostratigraphy and paleoceanography of the middle-latitude eastern North Pacific, Deep Sea Drilling Project Leg 63. In Yeats, R. S., Haq, B. U., et al., Init. Repts. DSDP, 63: Washington (U.S. Govt. Printing Office), 507538 .

1983. Latest Oligocene through early middle Miocene diatom biostratigraphy of the eastern tropical Pacific. Mar. Micropaleontol., 7:487-515.

in press a. Miocene-Holocene planktic diatoms. In Bolli, H. M., and Saunders, J. B. (Eds.), Biostratigraphy by Marine Plankton: New York (Cambridge University Press). 
in press b. Late Eocene to Holocene diatom biostratigraphy of the equatorial Pacific Ocean. In Mayer, L., Theyer, F., Init. Repts. DSDP, 85: Washington (U.S. Govt. Printing Office).

Barron, J. A., and Keller, G., 1982. Widespread Miocene deep-sea hiatuses: coincidence with periods of global cooling. Geology, 10: 577-581.

1983. Paleotemperature oscillations in the middle and late Miocene of the northeastern Pacific. Micropaleontology, 29(2): $150-181$.

Brun, J., 1891. Diatomées espèces nouvelles marines, fossiles ou pélagiques. Soc. Phys. Hist. Nat. Geneve Mem., 31:1-47.

1894. Espèces nouvelles. In Tempère, J. (Ed.) Le Diatomiste (Vol. 2): Paris (M. J. Tempère), 72-78, 86-88.

Brun, J., and Tempère, J., 1889. Diatomées fossiles du Japon, espèces marines et nouvelles des calçaires argileux des Sendai et de Yedo. Soc. Phys. Hist. Nat. Geneve Mem., 30:1-75.

Burckle, L. H., 1972. Late Cenozoic diatom zones from the eastern equatorial Pacific. Nova Hedwigia (Beih.), 39:217-250. 1977. Pliocene and Pleistocene diatom datums from the equatorial Pacific. Quat. Geol., 7:330-340. , 1978. Early Miocene to Pliocene diatom datum levels for the equatorial Pacific. Geol. Soc. Indonesia Proc., IGCP Project 114 Meetings, Indonesia, 1977. (Geol. Res. Devel. Cent., Spec. Publ.), 1:25-44.

Burckle, L. H., and Akiba, F., 1978. Implications of late Neogene fresh-water sediment in the Sea of Japan. Geology, 6:123-127.

Burckle, L. H., and Opdyke, N. D., 1977. Late Neogene diatom correlations in the circum-Pacific. In Saito, T., and Ujiié, H. (Eds.), Proc. First Int. Cong. Pacific Neogene Stratigraphy, Tokyo, 1976: Tokyo (Kaiyo Shuppan Co.), pp. 255-284.

Cleve-Euler, A., 1951-1955. Die Diatomeen von Schweden und Finnland. K. Svenska Vet.-Akad. Handl. (Stockholm), Fjärde Serien Bd. 2, No. 1, Teil I, pp. 1-163, 1951; Bd. 4, No. 1, Teil II, pp. 1158, 1953; Bd. 4, No. 5, Teil III, pp. 1-55, 1953; Bd. 5, No. 4, Teil IV, pp. 1-232, 1955; Bd. 3, No. 3, Teil V, pp. 1-153, 1952.

Cupp, E. E., 1943. Marine plankton diatoms of the West Coast of North America. Bull. Scripps Inst. Oceanogr., 5(1):1-238.

Donahue, J. G., 1970. Pleistocene diatoms as climate indicators in North Pacific sediments. In Hays, J. D. (Ed.), Geological Investigations of the North Pacific. Mem. Geol. Soc. Am., 126: pp. 121138.

Fenner, J., Schrader, H.-J., and Wienig, H., 1976. Diatom phytoplankton studies in the southern Pacific Ocean, composition and correlation to the Antarctic Convergence and its paleoecological significance. In Hollister, C. D., Craddock, C., et al., Init. Repts. DSDP, 35: Washington (U.S. Govt. Printing Office), 757-813.

Forti, D. A., 1913. Contribuzioni diatomologiche. XIII. Diagnoses Diatomacearum quarumdam fossilium italicarum. Atti Reale Inst. Veneto Sci., Lett. Arti, 72:1567-1700.

Fryxell, G. A., and Hasle, G. R., 1972. Thalassiosira eccentrica (Ehrenb.) Cleve, T. symmetrica sp. nov., and some related Centric diatoms. J. Phycol., 8(4):297-317.

1977. The genus Thalassiosira: species with a modified ring of central strutted process. Nova Hedwigia (Beih.), 54:67-98.

Gersonde, R., and Schrader, H.-J., 1984. Marine planktic diatom correlation of lower Messinian deposits in the western Mediterranean. Mar. Micropaleontol., 9:93-110.

Greville, R. K., 1861. Description of new and rare diatoms. Trans, $R$. Micr. Soc. London, 9, n. ser., ser. IV:79-87.

Hajós, M., 1968. Die Diatomeen der miozänen Ablagerungen des Mártavorlandes. Geol. Hung., Ser. Paleontol., 37:33-401. 1976. Upper Eocene and lower Oligocene Diatomaceae, Archaeomonadaceae and Silicoflagellatae in southwestern Pacific sediments, DSDP Leg 29. In Hollister, C. D., Craddock, C., et al., Init. Repts. DSDP, 35: Washington (U.S. Govt. Printing Office), 817-883.

Håkansson, H., and Locker, S., 1981. Stephanodiscus Ehrenberg 1846, a revision of the species described by Ehrenberg. Nova Hedwigia, 35:117-150.

Hanna, G. D., 1930. A revision of genus Rouxia. J. Palaeontol., 4(2): 179-188.

1932. The diatoms of Sharktooth Hill, Kern County, California. Proc. Calif. Acad. Sci., Ser. 4, 20(6):161-263.
Hanna, G. D., and Grant, W. M., 1926. Expedition to the Revillagigedo Island, Mexico, in 1925, II. Proc. Calif. Acad. Sci., Ser. 4, 15(2): $115-193$.

Haq, B. V., Berggren, W. A., and Van Couvering, J. A., 1977. Corrected age of the Pliocene-Pleistocene boundary. Nature, 269:483488.

Harland, W. B., Cox, A. V., Llewllyn, P. G., Pickton, C. A. G., Smith, A. G., and Walter, R., 1982. A Geologic Time Scale: New York (Cambridge Univ. Press).

Harper, H. E., Jr., 1977a. Diatom biostratigraphy of the Miocene-Pliocene boundary in marine strata of the circum-North Pacific $[\mathrm{Ph}$ D. dissert.]. Harvard University, Cambridge, Massachusetts. 1977b. Diatom biostratigraphy. In Ujiié, H., Saito, T., Kent, D. V., Thompson, P. R., Okada, H., Klein, G. V., Koizumi, I., Harper, H. E., and Sato, T. (Eds.), Biostratigraphy, paleomagnetism and sedimentology of late Cenozoic sediments in northeastern Hokkaido, Japan. Bull. Natl. Sci. Mus., Ser. C: Geol. Paleontol. (Tokyo), 3(2):85-90. (In Japanese)

, 1980. Diatom biostratigraphy of Sites 434,435 , and 436 northwestern Pacific, Leg 56, Deep Sea Drilling Project. In Scientific Party, Init. Repts. DSDP, 56, 57, Pt. 2: Washington (U.S. Govt. Printing Office), 633-639.

Hasle, G. R., 1960. Phytoplankton and ciliate species from the tropical Pacific. Skr. norske Vidensk Akad. Kl. 1, Mat.-Naturvidensk Kl., 2:1-50.

1965a. Nitzschia and Fragilariopsis species studied in the light and electron microscopes. II. The group Pseudonitzschia. Skr norske Vidensk Akad. Kl. 1, Mat.-Naturvidensk. Kl., 18:1-45. 1965b. Nitzschia and Fragilariopsis species studied in the light and electron microscopes. III. The genus Fragilariopsis. Skr. norske Vedensk Akad. Kl. 1, Mat.-Naturvidensk. Kl., 21:1-49. 1972. Fragilariopsis Hustedt as a section of the genus Nitzschia Hassall. Nova Hedwigia (Beih.), 39:111-119.

1979. Thalassiosira decipiens (Geun.) Jørg. (Bacillariophyceae). Bacillaria, 2:85-108.

Hasle, G. R., and Fryxell, G. A., 1977. The genus Thalassiosira: species with a linear areolae array. Nova Hedwigia (Beih.), 54:15-66.

Hasle, G. R., and Mendiola, B. R. E., 1967. The fine structure of some Thalassionema and Thalassiothrix species. Phycologia, 6(273): 107-125.

Heiden, H., and Kolbe, R. W., 1928. Die marinen Diatomeen der Deutschen Südpolar-Expedition, 1901-1903. In Drygalski, E. (Ed.), Deutsche Südpolar-Expedition, 1903: Berlin und Leipzig (Walter de Gruyter and Co.), 8(Botanik)(5):447-715.

Hendey, N. I., 1964. An Introductory Account of the Smaller Algae of British Coastal Waters. Fish. Invest., Bacillariophyceae (Diatoms) (Ser. 4, Pt. 5): London (HMSO). $4: 7-20$.

1981. Note on the genus Neobrunia O. Kuntze. Bacillaria,

Hustedt, F., 1927-1959. Die Kieselalgen Deutschland, Oestreichs und der Schweiz mit Berücksichtigung der übrigen Länder Europas sowie der angrenzenden Meeresgebiete. In Rabenhorst, L. (Ed.), Kryptogamen-Flora von Deutschland, Oestreichs und der Schweiz: Leipzig (Akademische Verlagsgesellschaft), Teil I, Sect. 1-4, pp. 1-920, 1927-1930; Teil II, Sect. 1-5, pp. 1-845, 1931-1959.

1930. Bacillariophyta (Diatomeae). In Pascher, A. (Ed.), Die Süsswasser-Flora Miteeleuropas, Heft 10.

1958. Diatomeen aus der Antarktis und dem Südatlantik. Dtsch. Antarktic Exped., 2:103-191.

Jousé, A. P., 1959. The main phases in the development of the flora of marine diatoms in the far eastern seas of the U.S.S.R. at the end of the Tertiary, and the Quaternary period. Bot. Mag., 44(1):44-55. (In Russian)

1961. Miocene and Pliocene marine diatoms from the Far East. Bot. Mater, Spor. Rast., Bot. Inst., Akad. Nauk, S.S.S.R., $16: 59-70$.

1968. New species of diatoms in bottom sediments of the Pacific and the Sea of Okhotsk. Nov. Systemat. Plant. Non Vascular, Acad. Nauk, S.S.S.R., 3:12-21.

Jousé, A. P. Petrushevskaya, M. G., Strelnikova, N. I., Dzinoridge, R. N., Ignatova, G. V., Lukina, T. G., Koltun, V. M., Golikova, G. S., Nagaeva, G. S., and Kozlova, G. E., 1979. The history of the microplankton of the Norwegian Sea on the Deep Sea Drilling ma- 
terial. Exploration of the Fauna of the Seas (Vol. 33): Moscow (Acad. Sci., U.S.S.R. Zool. Inst., Nauka). (In Russian)

Kanaya, T., 1959. Miocene diatom assemblages from the Onnagawa Formation and their distribution in the correlative formations in northeast Japan. Sci. Rep. Tohoku Univ., Ser. 2, 30:1-130.

1971. Some aspects of pre-Quaternary diatoms in the ocean. In Funnel, B., and Riedel, W. (Eds.), Micropaleontology of the Oceans: New York (Cambridge University Press), pp. 545-565.

Kanaya, T., and Koizumi, I., 1970. The progress in the younger Cenozoic diatom biostratigraphy in the northern circum-Pacific region. J. Mar. Geol., 6(2):47-66. (In Japanese with English abstract)

Kobayashi, K., Kitazato, K., Kanaya, T., and Sakai, T., 1971. Magnetic and micropaleontological study of deep-sea sediments from the west-central equatorial Pacific. Deep-Sea Res., 18:1045-1062.

Koizumi, I., 1968. Tertiary diatom flora of Oga Peninsula, Akita Prefecture, northeast Japan. Sci. Rep. Tohoku Univ., Ser. 2, 40(3): 171-225.

1972. Marine diatom flora of the Pliocene, Tatsunokuchi Formation in Fukushima Prefecture. Trans. Proc, Palaeontol. Soc. Jpn., New Ser., 86:340-359.

1973a. The stratigraphic ranges of marine planktonic diatoms and diatom biostratigraphy in Japan. Mem. Geol. Soc. Jpn., $8: 35-44$.

1973b. The late Cenozoic diatoms of Sites 183-193, Leg 19 Deep Sea Drilling Project. In Creager, J. S., Scholl, D. W., et al., Init. Repts. DSDP, 19: Washington (U.S. Govt. Printing Office), 805-855.

1975a. Neogene diatoms from the western margin of the Pacific Ocean, Leg 31, Deep Sea Drilling Project. In Karig, D. E., Ingle, J. C., Jr., et al., Init. Repts. DSDP, 31: Washington (U.S. Govt. Printing Office), 779-819.

1975b. Neogene diatoms from the northwestern Pacific Ocean, Deep Sea Drilling Project. In Larson, R. L., Moberly, R., et al., Init. Repts. DSDP, 32: Washington (U.S. Govt. Printing Office), $865-889$.

1975c. Late Cenozoic diatom biostratigraphy in the circumNorth Pacific region. J. Geol. Soc. Jpn., 81(10):611-627.

1977. Diatom biostratigraphy in the North Pacific region. In Saito, T., and Ujiié, H. (Eds.), Proc. First Int. Congr. Pacific Neogene Stratigraphy, Tokyo, 1976: Tokyo (Kaiyo-Shuppan Co.), pp. $235-253$.

1979. The geological history of the Sea of Japan-based upon sediments and microfossils. Circ. Nihonkai (Japan Sea), 10: 69-90. (In Japanese)

1980. Neogene diatoms from the Emperor Seamount Chain, Leg 55, Deep Sea Drilling Project. In Jackson, E. D., Koizumi, I., et al., Init. Repts. DSDP, 55: Washington (U.S. Govt. Printing Office), $387-407$.

1982. Distribution and depositional environments of marine diatomaceous sediments in Japan and its environs. Chikyu, 4(8):485-491. (In Japanese)

Koizumi, I., Barron, J. A., and Harper, H. E., Jr., 1980. Diatom correlation of Legs 56 and 57 with onshore sequences in Japan. In Scientific Party, Init. Repts. DSDP, 56, 57, Pt. 2: Washington (U.S. Govt. Printing Office), 687-693.

Koizumi, I., and Kanaya, T., 1976. Late Cenozoic marine diatom sequence from the Choshi district, Pacific coast, central Japan. In Takayanagi, Y., and Saito, T. (Eds.), Progress in Micropaleontology: New York (Micropaleontol. Press, Spec. Publ.), pp. 144-159.

Koizumi, I., and Ujiié, H., 1976. On the age of the Nobori Formation, Shikoku, southwest Japan-particularly based on diatoms. Mem. Natl. Sci. Mus., Ser. C.: Geol. (Tokyo), 9:61-72.

Kolbe, R. W., 1954. Diatoms from equatorial Pacific cores. Rep. Swed. Deep-Sea Exped. 1947-1948, 6(1): Göteborg (Elanders Boktryckeri Aktiebolag), 1-58.

1955. Diatoms from equatorial Atlantic cores. Rep. Swed. Deep-Sea Exped. 1947-1948, 7(3): Göteborg (Elanders Boktryckeri Aktiebolag), 150-189.

Komura, S., 1975. Ikebea, eine neue Gattung der Pennaten Bacillariaceen aus dem Neogene Japans. Trans. Proc. Palaeontol. Soc. Jpn., New Ser., 99:133-142.

1976. Sawamuraia, Katahiraia und Yoshidaia, drei neue Diatomgattungen aus dem Neogene Japans. Trans. Proc. Palaeontol. Soc. Jpn., New Ser., 103:379-397.
1980. A new genus of cuneate diatoms from the Miocene Masuporo Formation of the Tenpoku district, Japan. Professor Saburo Kanno Memorial Volume: Tsukuba (Memorial Association of Professor Saburo Kanno's Retirement, Tsukuba Univ.), 373-378.

Lohman, K. E., 1938. Pliocene diatoms from the Kettleman Hills, California. US Geol. Surv. Prof. Pap., 189-c:81-102.

1948. Middle Miocene diatoms from the Hammond Well. Cretaceous and Tertiary Subsurface Geology. Maryland Dept. Mines Geol. Bull., 2:151-187.

Maruyama, T., 1984. Miocene diatom biostratigraphy of onshore sequences on the Pacific side of northeast Japan, with reference to DSDP Hole 438A. Sci. Rep. Tohoku Univ., Ser. 2, (part 1), 54(2): 141-164, (part 2), 55(1):77-140.

Mertz, D., 1966. Mikropaläontologische und sedimentologische Untersuchung der Pisco Formation Südperus. Palaeontographica, Bd. 118(Abt. B):1-51.

Muchina, Y. U., 1965. New species of diatoms from the bottom sediments of the equatorial region of the Pacific. Nov. Systemat. Plant. non Vascular Bot. Inst. Akad. Nauk S.S.S.R., pp. 22-25.

Niitsuma, N., 1978. Magnetic stratigraphy of the Japanese Neogene and the development of the island arcs of Japan. J. Phys. Earth, 26(Suppl.):367-378.

Rattray, J., 1890. A revision of the genus Actinocyclus Ehr. J. Quekett Microsc. Club, Ser. 2, 4:137-212.

Ryan, W. B. F., Chita, M. B., Rawson, M. D., Burckle, L. H., and Saito, T., 1974. A paleomagnetic assignment of Neogene Stage boundaries and the development of isochronous datum planes between the Mediterranean, the Pacific and Indian oceans in order to investigate the response of the world ocean to the Mediterranean "Salinity Crisis." Riv. Ital. Paleontol., 80(4):631-688.

Sancetta, C., 1982. Distribution of diatom species in surface sediments of the Bering and Okhotsk seas. Micropaleontology, 28(3): 221-257.

Schmidt, A., 1874-1959. Atlas der Diatomaceenkunde: Leipzig, Berlin (O. R. Reisland). (Begun by Schmidt, A., continued by Schmidt, M., Fricke, F., Heiden, H., Müller, O., and Hustedt, F.)

Schrader, H.-J., 1973a. Cenozoic diatoms from the northeast Pacific, Leg 18. In Kulm, L. D., von Huene, R., et al., Init. Repts. DSDP, 18: Washington (U.S. Govt. Printing Office), 673-797.

1973b. Stratigraphic distribution of marine Denticula species in Neogene North Pacific sediments. Micropaleontology, 19(4): 417-430.

1974a. Cenozoic marine planktonic diatom stratigraphy of the tropical Indian Ocean. In Fisher, R. L., Bunce, E. T., et al., Init. Repts. DSDP, 24: Washington (U.S. Govt. Printing Office), 887-967.

, 1974b. Revised diatom stratigraphy of the experimental Mohole drilling, Gaudalupe site. Proc. Calif. Acad. Sci., 4th Ser., 39: 517-562.

1976. Cenozoic planktonic diatom biostratigraphy of the southern Pacific Ocean. In Hollister, C. D., Craddock, C., et al., Init. Repts. DSDP, 35: Washington (U.S. Govt. Printing Office), 605-671.

Schrader, H.-J., and Fenner, J., 1976. Norwegian Sea Cenozoic diatom biostratigraphy and taxonomy. In Talwani, M., Udintsev, G., et al., Init. Repts. DSDP, 38: Washington (U.S. Govt. Printing Office), 921-1099.

Schrader, H.-J., and Gersonde, R., 1978. Diatoms and silicoflagellates. In Zachariasse, W. J., Riedel, W. R., Sanfilippo, A., et al. (Eds.), Micropaleontological Methods and Techniques-An Exercise on an Eight-Meter Section of the Lower Pliocene of Capo Rossello, Sicily, IGCP Project, No. 1: Utrecht (Utrecht Micropal. Bull), 17:129-176.

Schuette, G., and Schrader, H., 1982. Thalassiothrix pseudonitzschioides sp. nov.: a common pennate diatom from the Gulf of California. Bacillaria, 5:213-223.

Semina, G. I., 1956. De specie nova generis Denticula Ktz. notula. Notul. systemat. e sect. cryptogam. Inst. Botan. nomine V. L. Komarovii Acad. Sci. USSR, 11:82-84. (In Russian)

Sheshukova-Poretzkaya, V. S., 1959. On fossil diatom flora of South Sakhaline (Marine Neogene). Bull. LGU, Biol. Ser., 15(3):36-55. (In Russian with English abstract) 
1962. New and rare Bacillariophyta from diatom suite of North Sakhaline. Study Note LGU (No. 313), Ser. biol., 49:203211. (In Russian)

, 1964. New and rare marine diatoms of the Neogene of Sakhaline and Kamtschatica. Nov. Systemat. Plant. Non Vascular Bot. Inst. Acad. Nauk S.S.S.R., pp. 69-77. (In Russian)

1967. Neogene Marine Diatoms of Sakhaline and Kamtchatica: Leningrad (Izd. Leningr. Univ.). (In Russian with English abstract)

Simonsen, R., 1974. The diatom plankton of the Indian Ocean expedition of R/V "Meteor" 1964-1965. "Meteor" Forschungsergeb., Ser. D, 19:1-107.

1975. On the pseudonodules of the Centric diatoms, or Hemidiscaceae reconsidered. Nova Hedwigia (Beih.), 53:83-97. 2:9-71.

1979. The diatom system: Ideas on phylogeny. Bacillaria,

Simonsen, R., and Kanaya, T., 1961. Notes on the marine species of the diatom genus Denticula Kütz. Int. Rev. Gesamten Hydrobiol., 46(4):498-513.

Syvertsen, E. E., 1979. Resting spore formation in clonal cultures of Thalassiosira antarctica Comber, T. nordenskioeldii Cleve, and Detonula confervacea (Cleve) Grun. Nova Hedwigia (Beih.), 64:4163.

Tanimura, Y., 1981a. Late Quaternary diatoms of the Sea of Japan. Sci. Rep. Tohoku Univ., Ser. 2, 51(1\&2):1-37.

, 1981b. Late Quaternary marine diatom Ethmodiscus rex from the northwestern Pacific Ocean. Bull. Natl. Sci. Mus., Ser. C: Geol. (Tokyo), 7(3):91-97.

Tsuchi, R., and IGCP-114 National Working Group of Japan, 1979. Fundamental Data on Japanese Neogene Bio- and Chronostratigraphy: Shizuoka (Shizuoka University). (In Japanese) 1981a. Fundamental Data on Japanese Neogene Bio- and Chronostratigraphy-Supplement: Shizuoka (Shizuoka University). (In Japanese)

1981b. Neogene of Japan-Its Biostratigraphy and Chronology: Shizuoka (Shizuoka University).

Ujiié, H., 1979. Two problems on the Sea of Japan geohistory-Quaternary benthic foraminifera faunas and age of the spreading. Circ. Nihonkai, 10:56-68. (In Japanese)

1981. Middle Miocene hiatus and the spreading of the Sea of Japan. Kaiyo-Kagaku, 13(2):101-111. (In Japanese)

1982. Geological history of the Sea of Japan: problems from the standpoints of sediments and microfossils. In Hoshi, M., and Shibata, T. (Eds.), Geology of the Sea of Japan: Tokyo (Tokai University Press), pp. 377-407. (In Japanese with English abstract)

Wiseman, J. D. H., and Hendey, N. I., 1953. The significance and diatom content of a deep-sea floor sample from the neighborhood of the greatest ocean depth. Deep-Sea Res., 1:47-59.

Wornardt, W. W., 1967. Miocene and Pliocene marine diatoms from California. Occas. Pap. Calif. Acad. Sci., 63:1-108.

1972. Stratigraphic distribution of diatom genera in marine sediments in western North America. Palaeogeogr., Palaeoclimatol., Palaeoecol., 12:49-74.

Yamanoi, T., 1978. Neogene pollen stratigraphy of the Sado Island, Niigata Prefecture, Japan. J. Jpn. Assoc. Pet. Technol., 43(3): 119-127. (In Japanese with English abstract)

Zabelina, M. M., 1934. Diatoms from the Tertiary deposits of the eastern coast of Kamtchatka. Trans. Oil Geol. Inst., Ser. A, Ed. 48:3-19. (In Russian)

Date of Initial Receipt: 18 April 1984 Date of Acceptance: 22 February 1985 


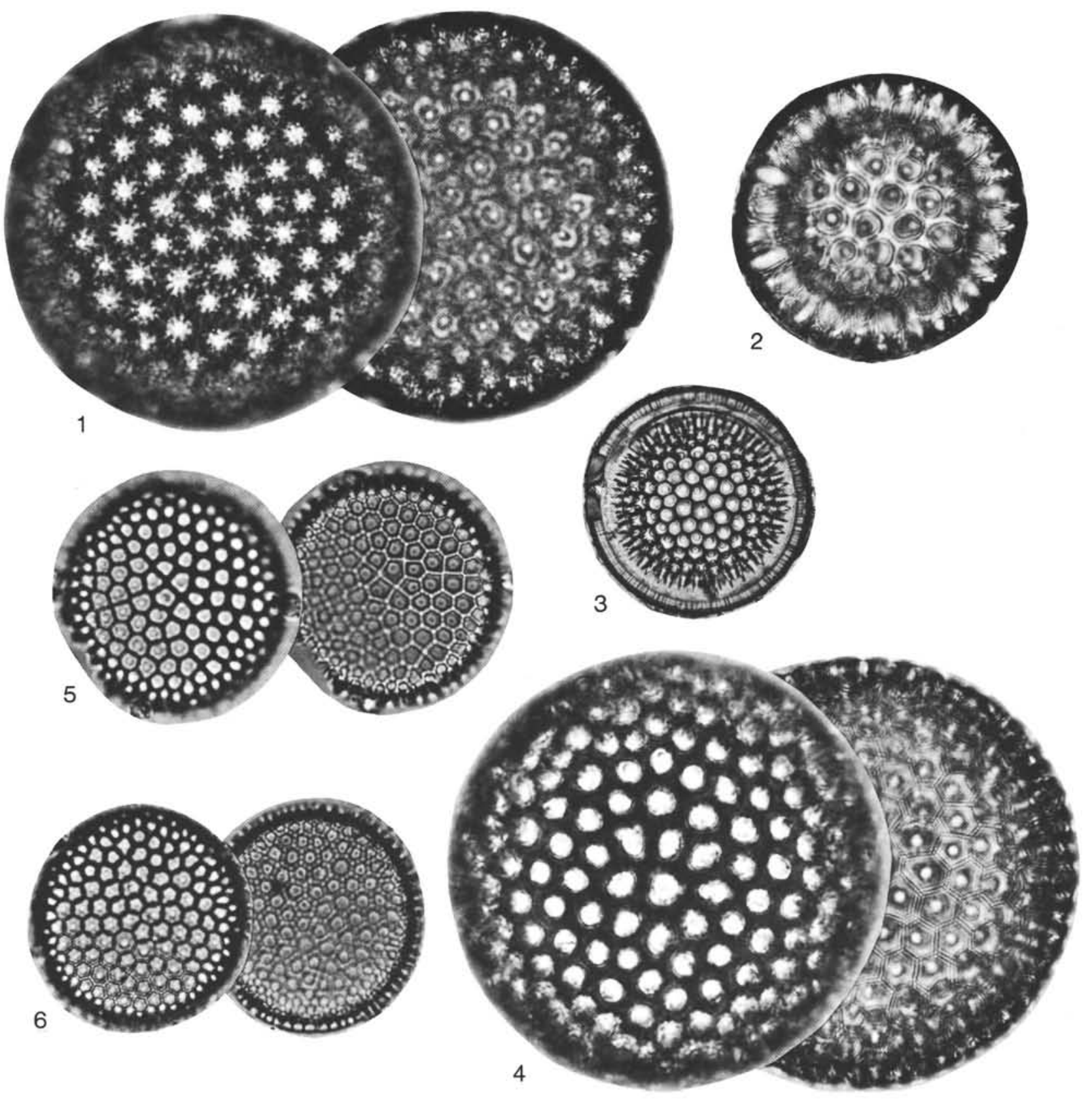

Plate 1. (Magnification $\times 1500$; Fig. 3, $\times 600$.) 1-4. Coscinodiscus marginatus Ehrenberg, (1) Sample 584-23,CC, valve with well-preserved cribrum, "Coscinodiscus marginatus f. fossilis Jousé" type, (2) Sample 438A-48-7, 30-31 cm, (3) Sample 438A-45-7, 10-11 cm, valve with connecting band, biological inner view, in which foramen can be clearly seen, (4) Sample 438A-48-7, 30-31 cm, valve with poorly preserved cribrum. 5-6. Coscinodiscus $\mathrm{cf}$, radiatus Ehrenberg, Sample 583-4-1, 47-48 cm. 


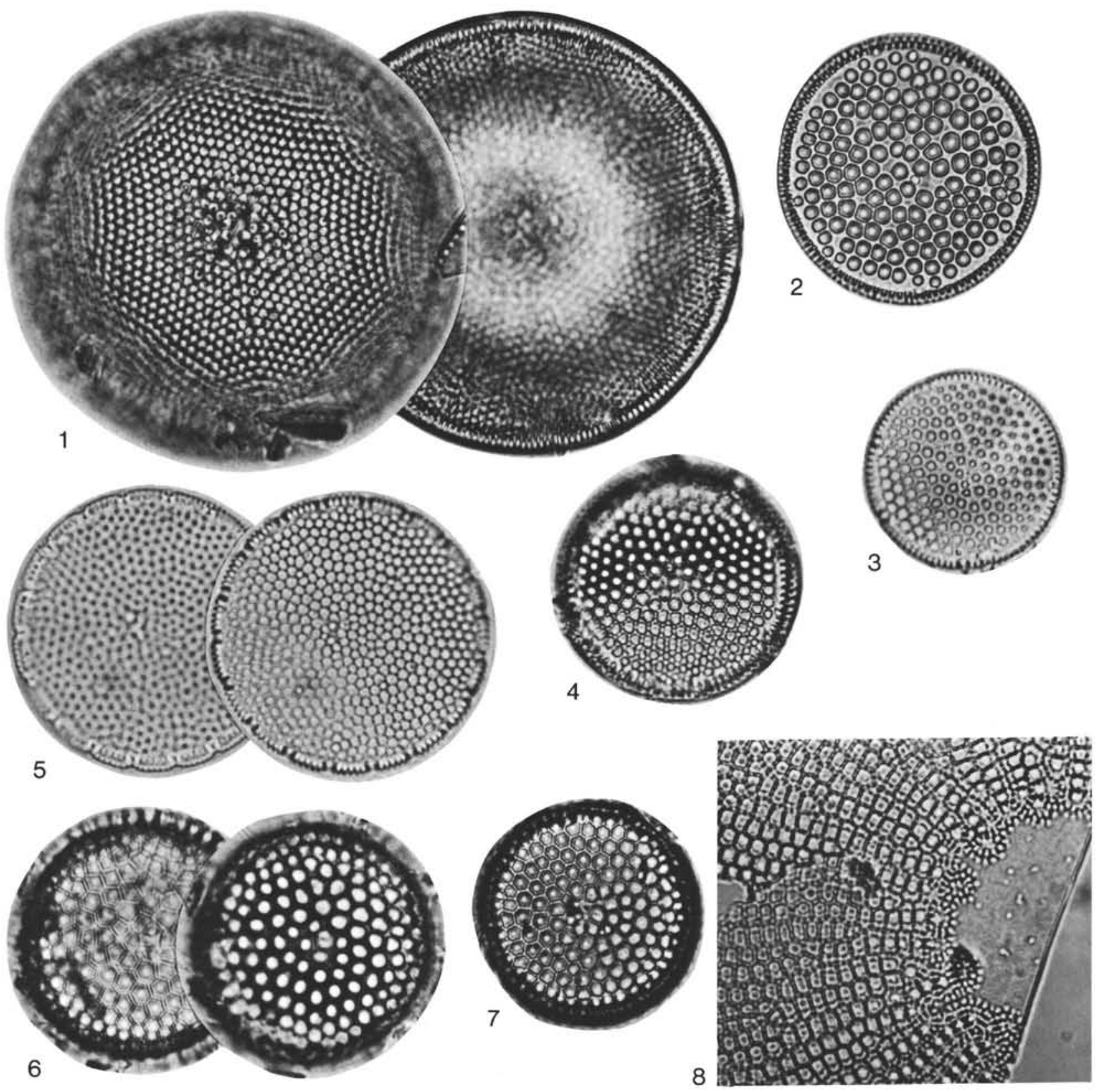

Plate 2. (Magnification $\times 1500$.) 1. Coscinodiscus symbolophorus Grunow, Sample 438A-42-1, 90-92 cm. 2. Coscinodiscus endoi Kanaya, Sample JDS-11833, a lower part of the Taga Group, Joban Area, northeastern Honshu. 3-4. Coscinodiscus tabularis Grunow, (3) Sample 584-1-1, 0-3 cm, (4) Sample 438A-42-4, 73-74 cm. 5. Coscinodiscus crenulatus Grunow, Sample 583-10-1, 116-117 cm. 6-7. Coscinodiscus nodulifer A. Schmidt, (6) Sample 584-19,CC, (7) Sample 583-4-1, 47-48 cm. 8. Coscinodiscus wailesii Gran and Angust, Sample 583-4-1, $47-48 \mathrm{~cm}$. 


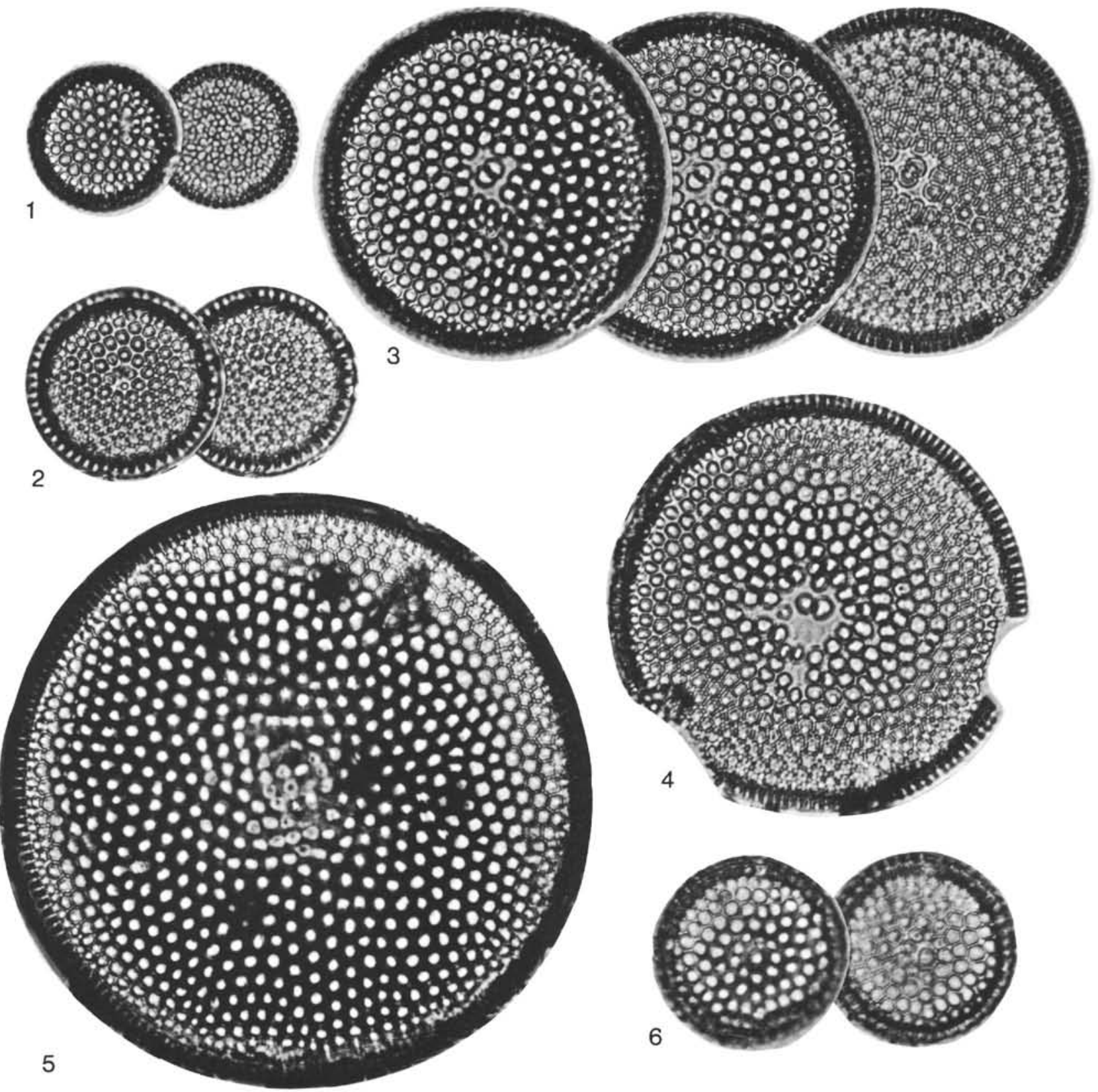

Plate 3. (Magnification $\times 1500$.) 1-5. Coscinodiscus sp. A, Sample 584-52,CC. 6. Coscinodiscus nodulifer A. Schmidt, Sample 584-32,CC. 

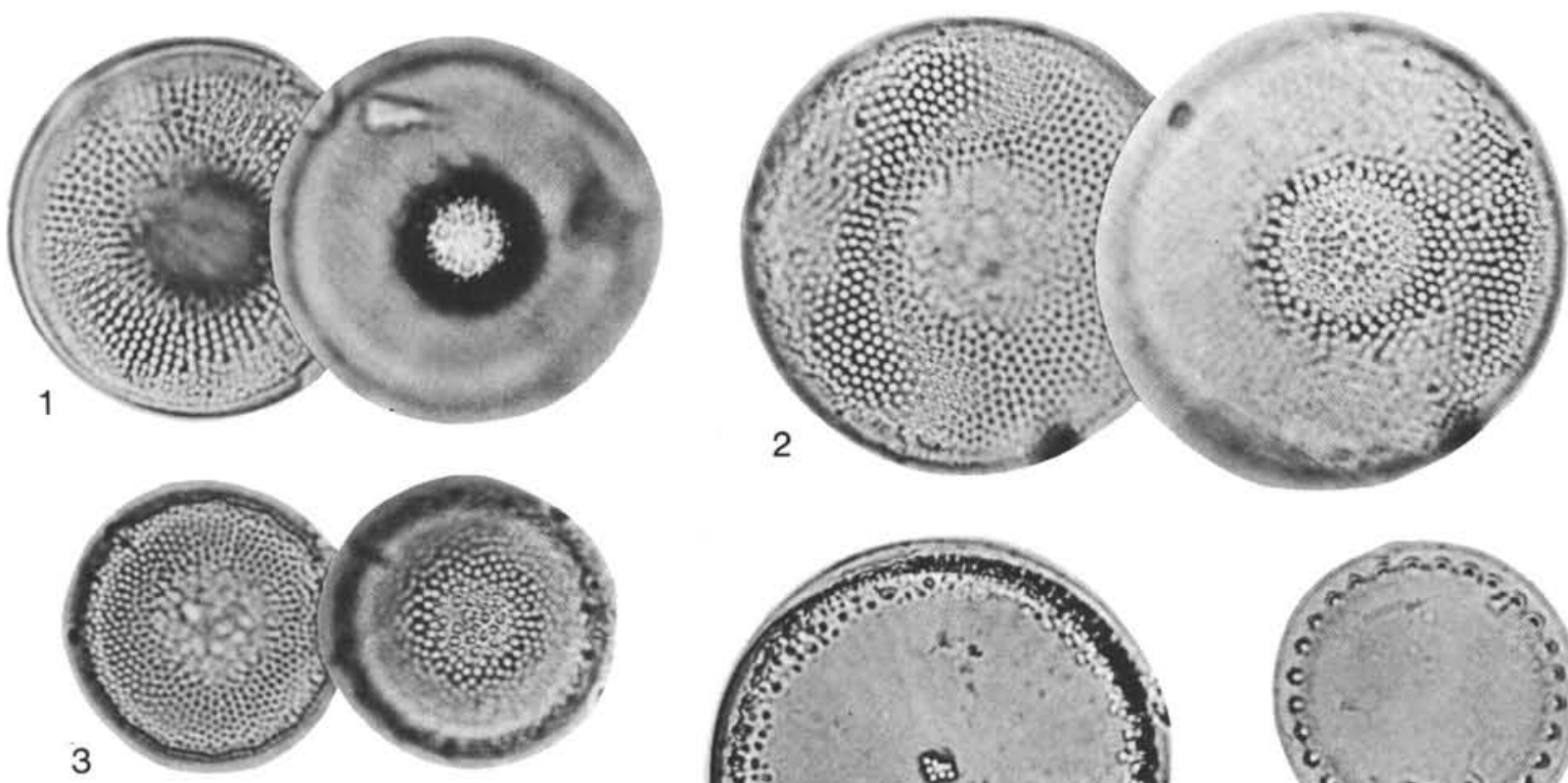
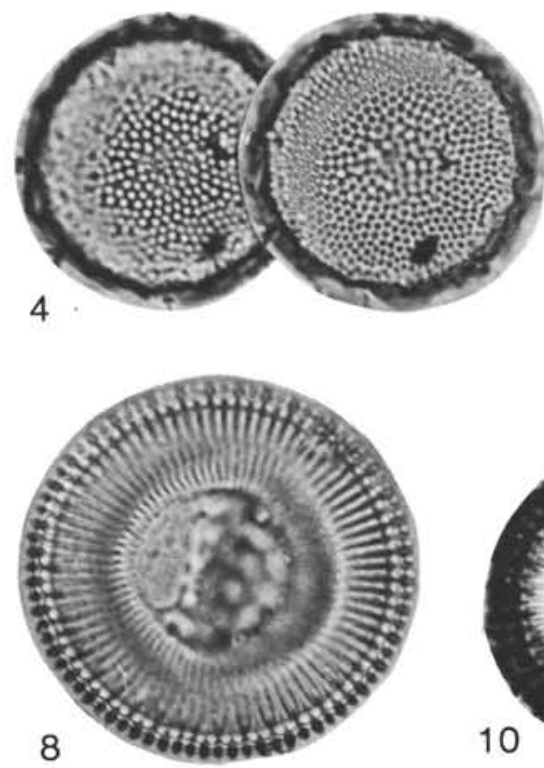

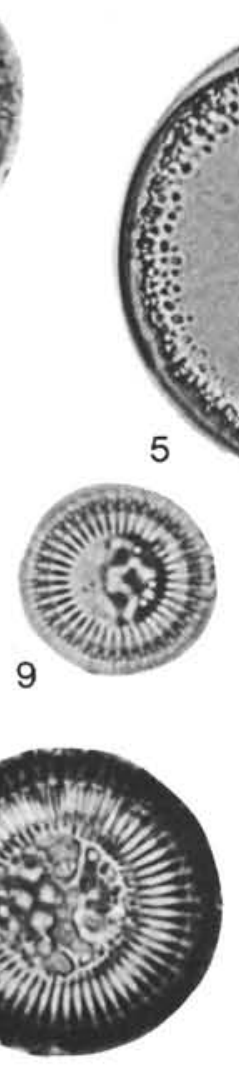

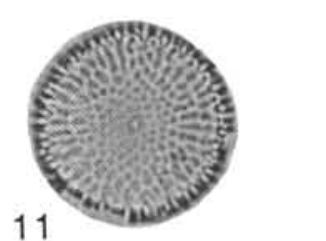

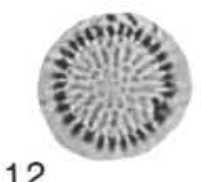

12
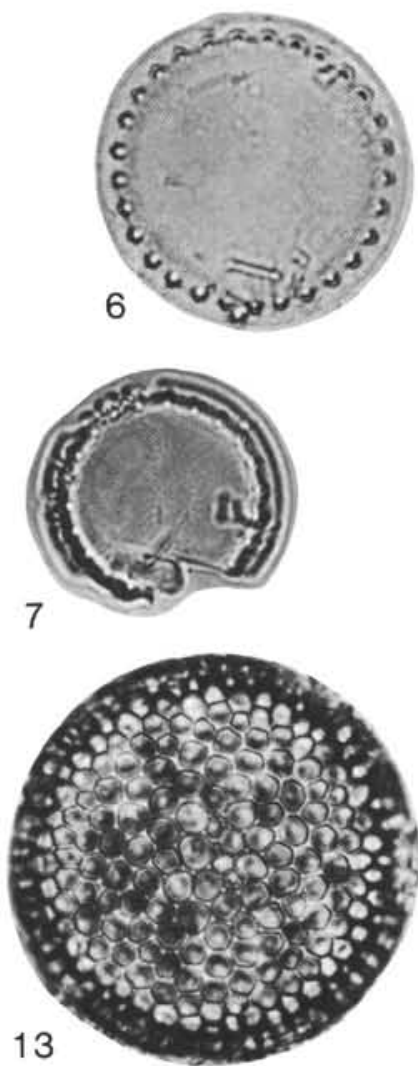

Plate 4. (Magnification $\times 1500$.) 1-4. Bacterosira fragilis (Gran) Gran, (1-3) Sample 584-1-1, 0-3 cm (1, valve with strongly convex center; 2-3, valve with flat valve face), (4) Sample 584-4,CC, valve with flat valve face. 5-7. Pseudopodosira elegans Sheshukova-Poretzkaya, (5-6) Sample 438A-42-4, 73-74 cm, (7) Sample 584-54,CC. 8-10. Cyclotella striata (Kützing) Grunow, (8, 10) Sample 584-1-1, 0-3 cm, (9) Sample 584-4,CC. 11-12. Melosira albicans Sheshukova-Poretzkaya, Sample 584-4,CC. 13. Stephanopyxis dimorpha Schrader, Sample 584A-H1-5, 100-101 cm. 

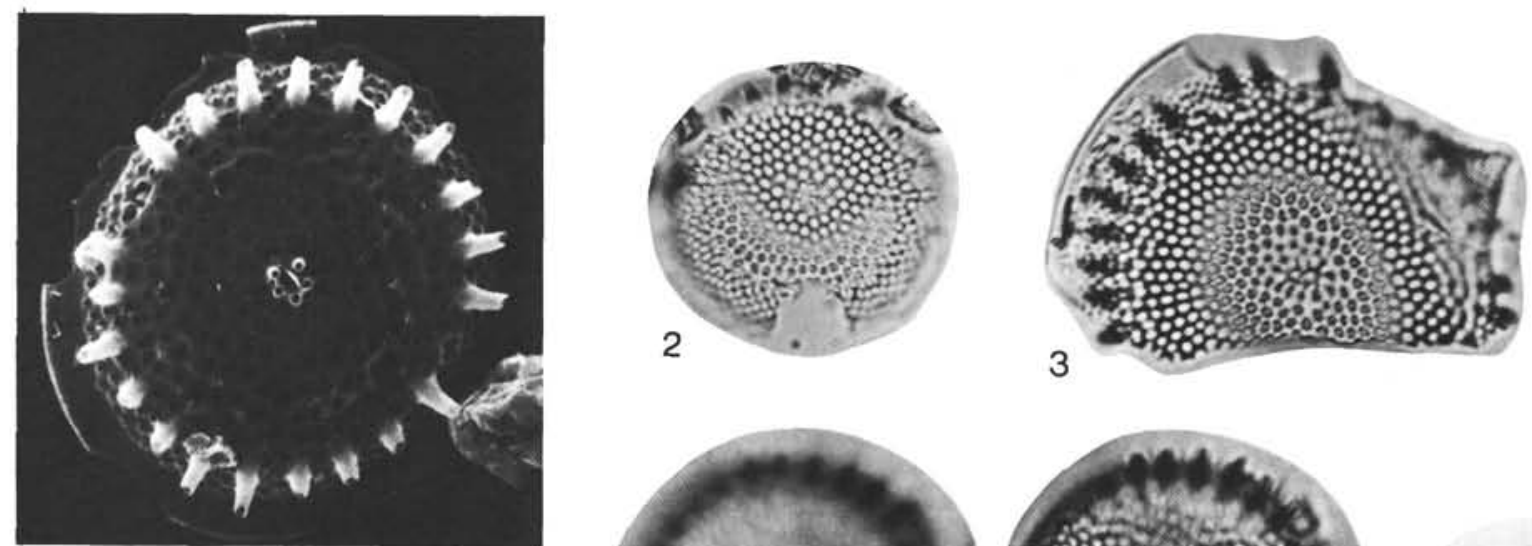

1

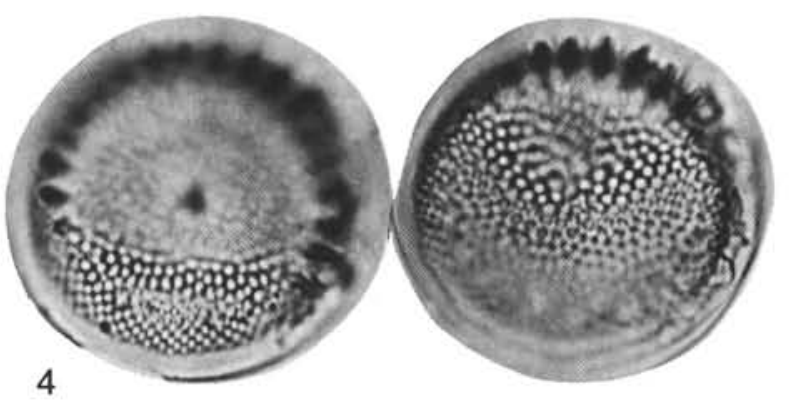

5
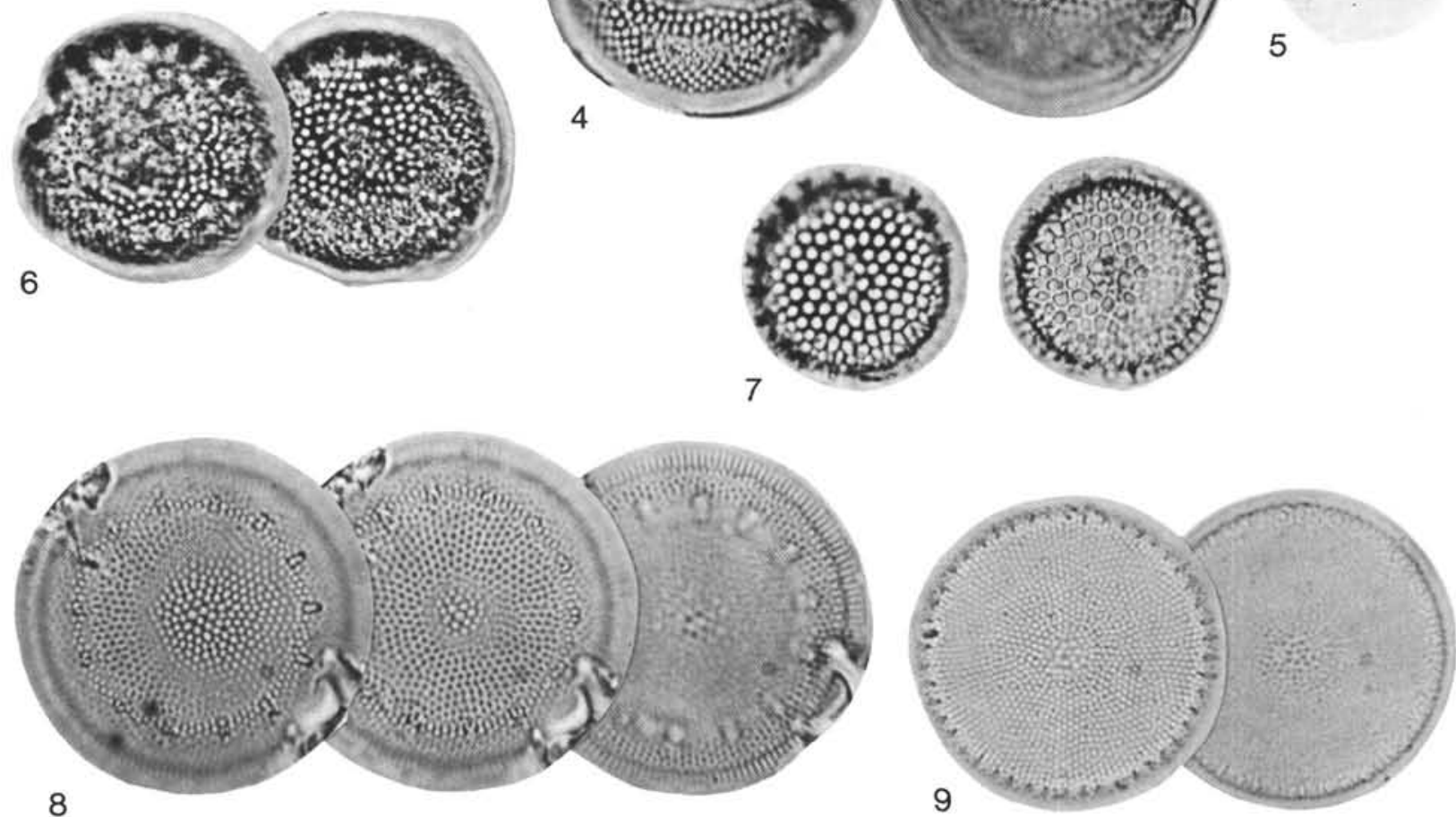

Plate 5. (Magnification $\times 1500$; Fig. 1, $\times 3300$.) 1-6. Thalassiosira urahoroensis Akiba n. sp., (1) Scanning electron microscopy, Sample JDS-6539, Keihoku Diatomite, Tenpoku Area, northern Hokkaido, (2-4) Sample JDS-11452, Chokubetsu Formation, Atsunai Area, eastern Hokkaido (2, holotype), (5-6) Sample 438A-60-3, 26-27 cm. 7. Thalassiosira praenidulus Akiba n. sp., Sample JDS-11452, Chokubetsu Formation, Atsunai Area, eastern Hokkaido. 8. Thalassiosira nordenskioeldii Cleve, Sample 584-1-1, 0-3 cm. 9. Thalassiosira hyalina (Grunow) Gran, Sample $584-1-1,0-3 \mathrm{~cm}$. 

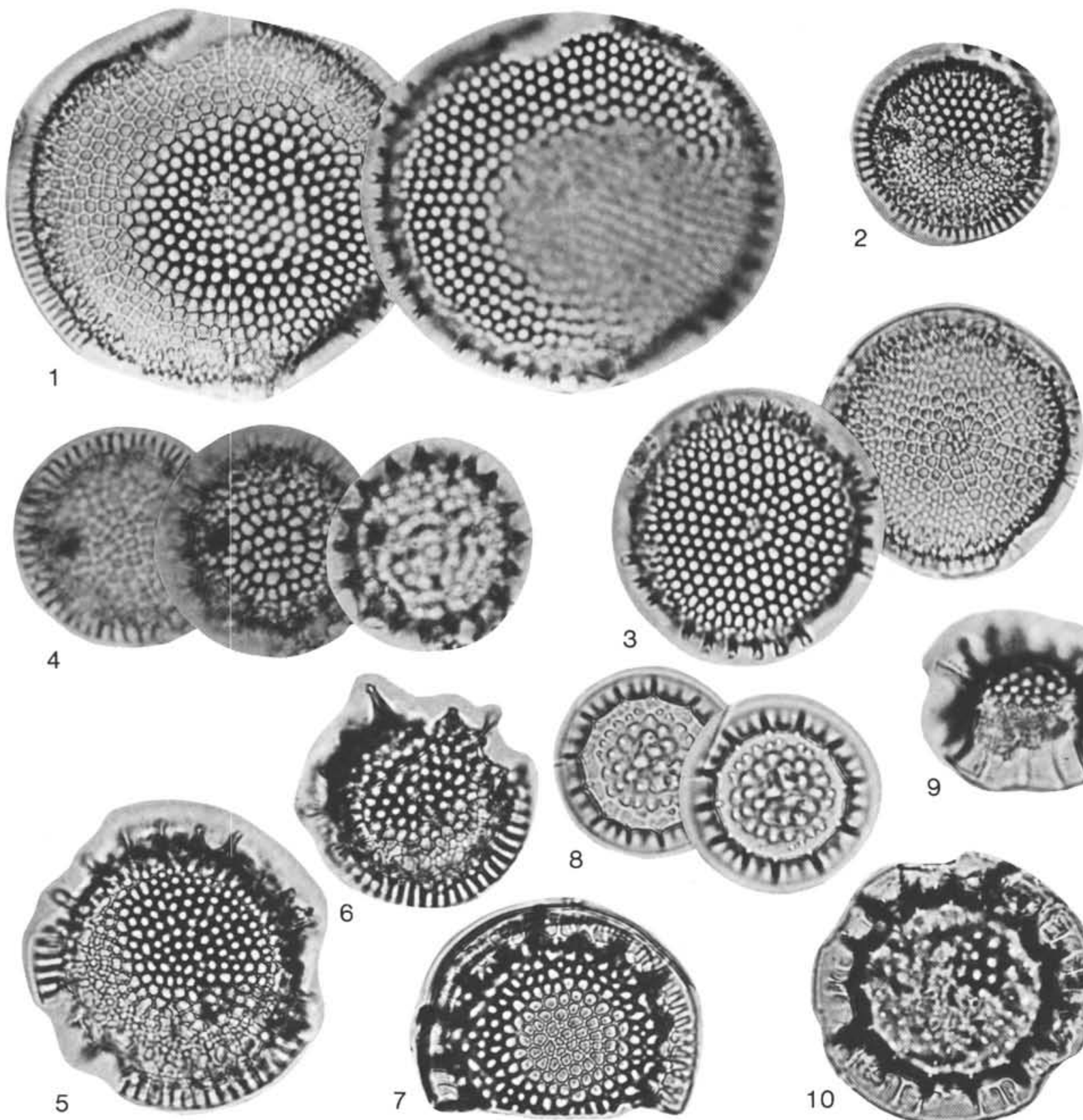

(2) 

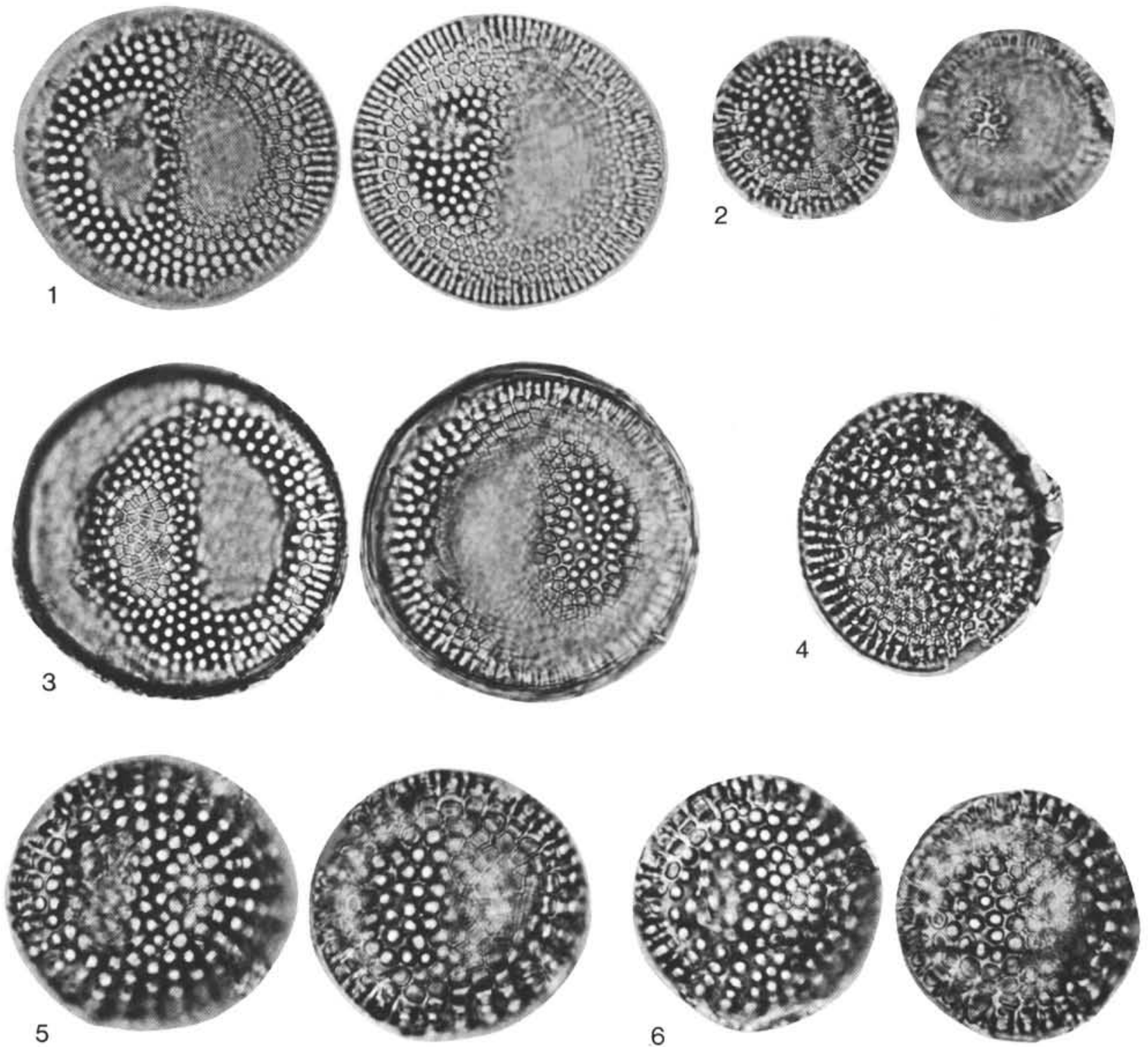

Plate 7. (Magnification $\times 1500$.) 1-3. Thalassiosira sancettae Akiba n. sp., (1) holotype, Sample 584-1-1, 0-3 cm, (2) Sample 584-1-2, 83-85 cm,

(3) Sample 584A-H1-5, 100-101 cm. 4. Thalassiosira temperei (Brun) Akiba and Yanagisawa, Sample 584-56,CC. 5-6. Thalassiosira yabei (Kanaya) Akiba and Yanagisawa, (5) Sample 584-80,CC, (6) Sample 584-79,CC. 

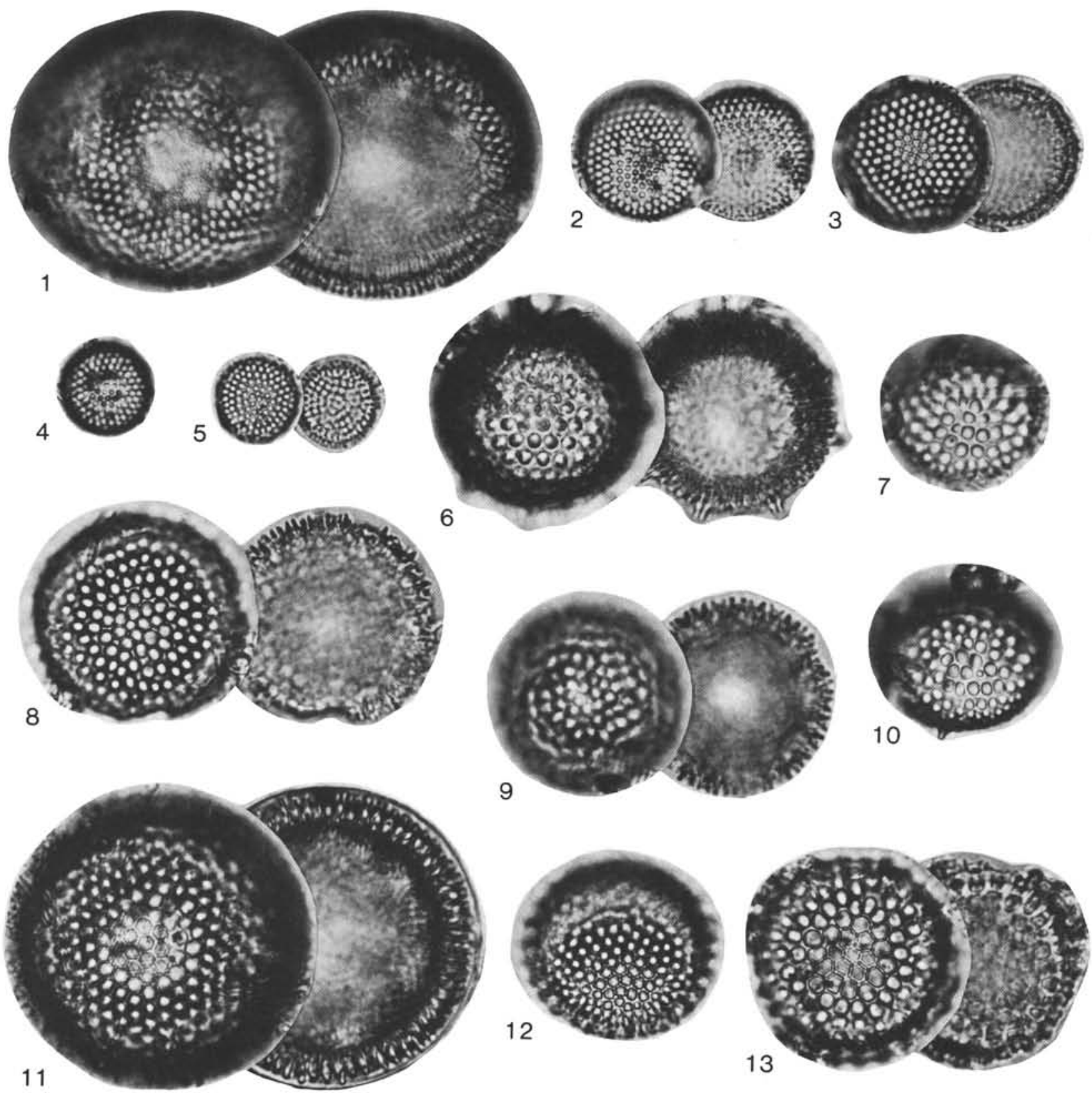

Plate 8. (Magnification $\times 1500$.) 1. Thalassiosira convexa Muchina, Sample 584-27,CC. 2-3. Thalassiosira miocenica Schrader, (2) Sample 438A-42-2, 95-96 cm, (3) Sample 438A-41,CC. 4. Thalassiosira $\mathrm{cf}$. miocenica Schrader, Sample 438A-42-2, 95-96 cm. 5. Thalassiosira $\mathrm{cf}$. praeconvexa Schrader, Sample 192-24,CC. 6-7, 9-10. Thalassiosira aff. zabelinae Jousé, (6-7) Sample 183-17-3, 80-82 cm, (9) Sample 183-15,CC, (10) Sample 438A-41,CC. 8. Thalassiosira cf. fraga Schrader, Sample 439-18-3, 53-55 cm. 11. Thalassiosira zabelinae Jousé, Sample 584-35,CC. 12-13. Thalassiosira fraga Schrader, (12) Sample 439-18-3, 53-55 cm, (13) Sample 439-20-3, 22-24 cm. 

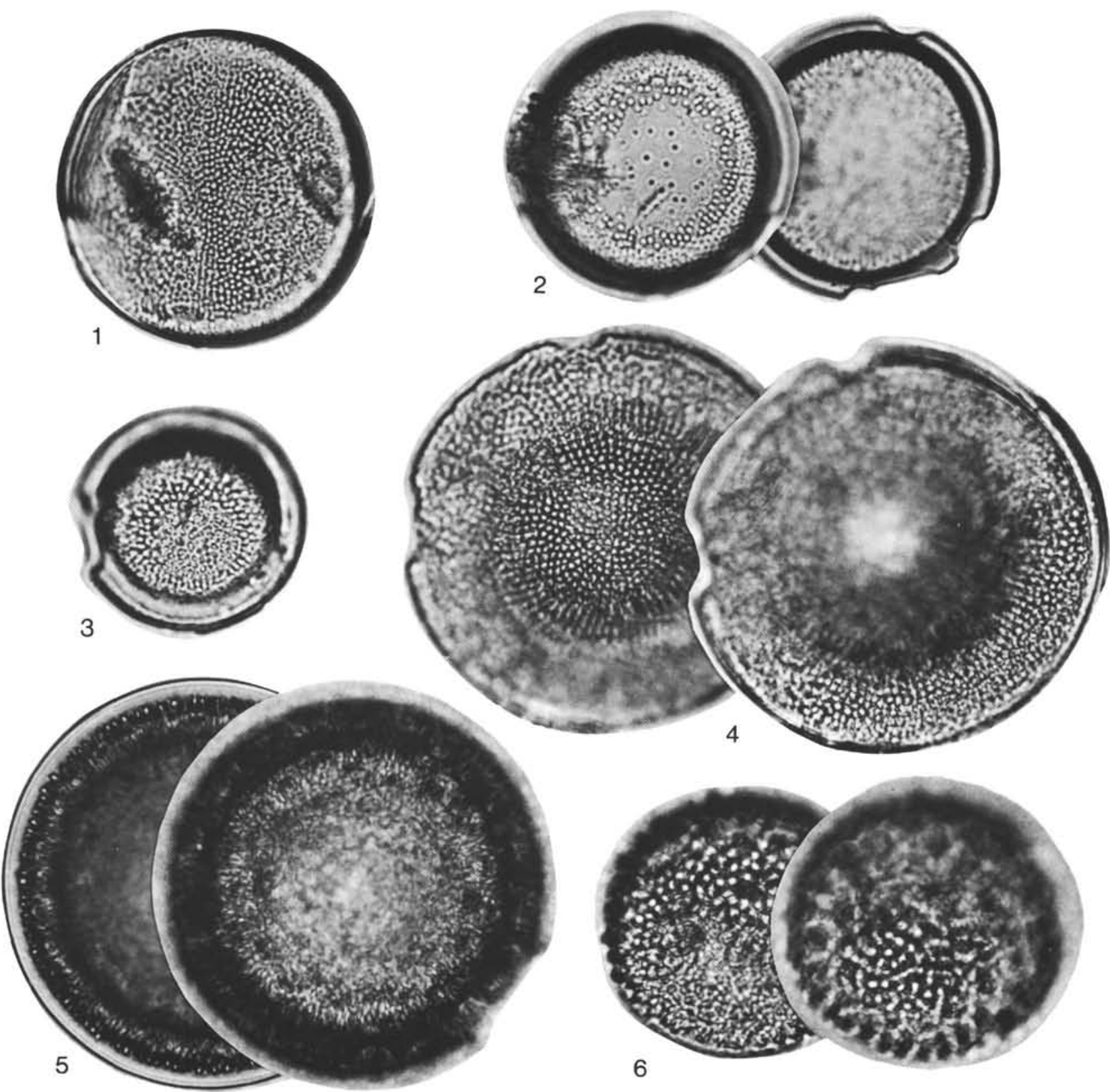

Plate 9. (Magnification $\times 1500$.) 1-3. Thalassiosira manifesta Sheshukova-Poretzkaya, (1) Sample 438A-42,CC, (2) Sample 438A-42-4, 73-74 cm, (3) Sample 438A-60-3, 26-27 cm. 4. Thalassiosira undulosa (Mann) Sheshukova-Poretzkaya, Sample 438A-42,CC. 5-6. Thalassiosira punctata Jousé, (5) Sample 438A-24-4, 73-74 cm, "punctate" type, (6) Sample 438A-42-1, 90-91 cm, "spinose" type. 

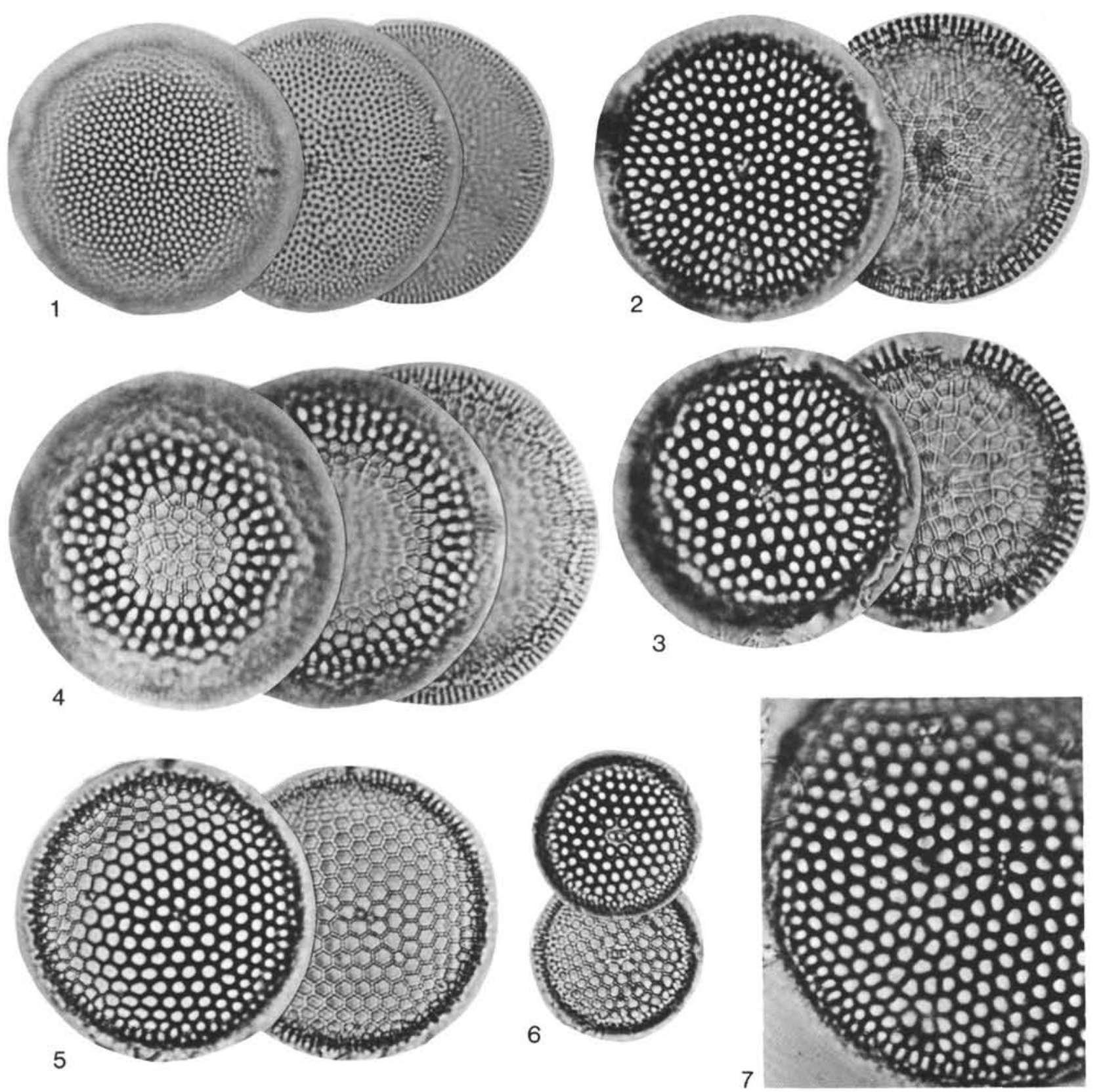

Plate 10. (Magnification $\times 1500$.) 1. Thalassiosira gravida Cleve, Sample 584-1-1, 0-3 cm, Quaternary type with fine areolae. 2-3. Thalassiosira gravida Cleve, (2) Sample 438A-41,CC, (3) Sample 584-9,CC, Pliocene type. 4. Thalassiosira gravida Cleve, Sample 584-1-1, 0-3 cm, Quaternary type with coarse areolae. 5-7. Thalassiosira trifulta Fryxell, (5, 7) Sample 584-1-1, 0-3 cm, (6) Sample 584-10,CC. 

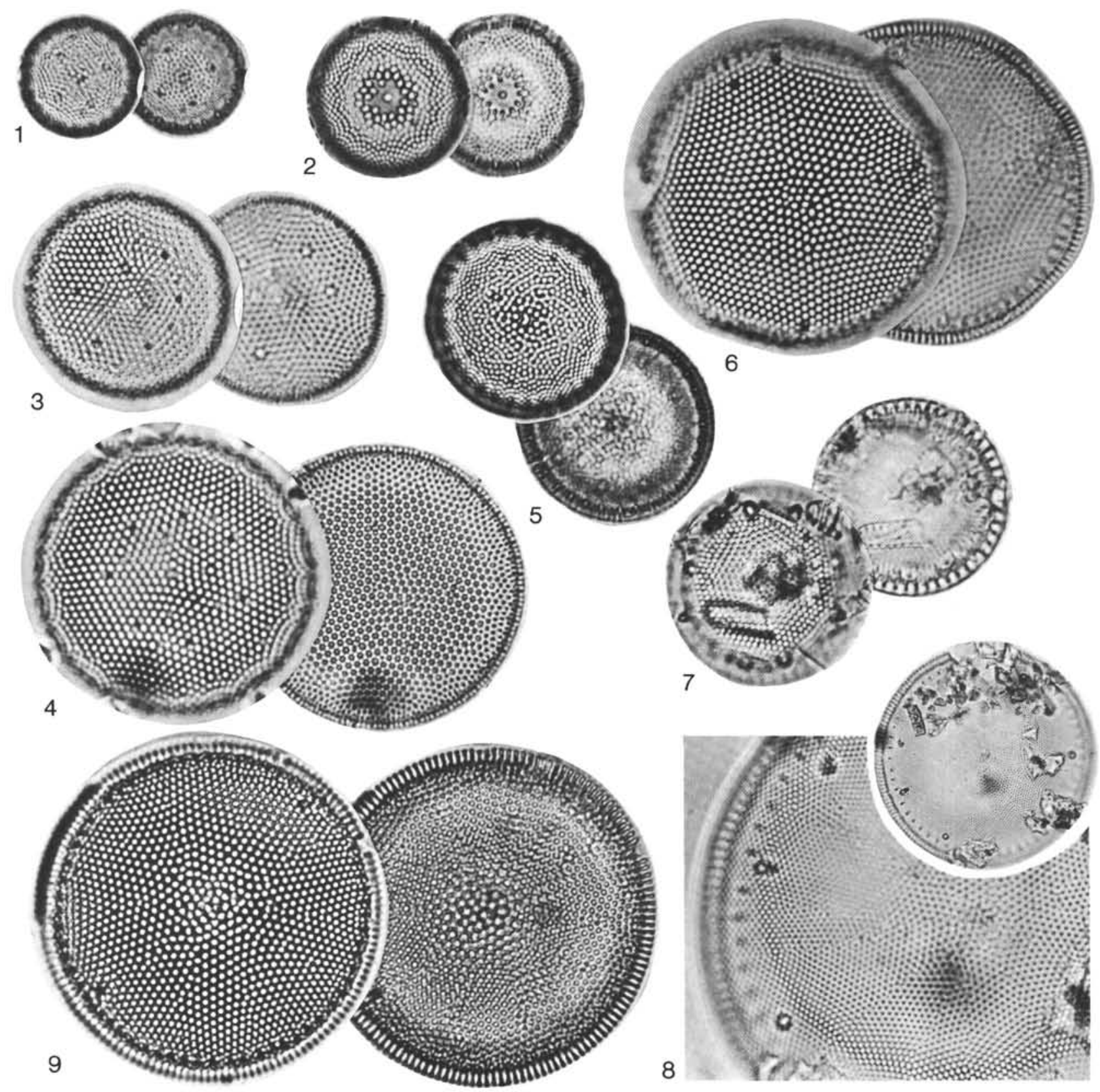

6
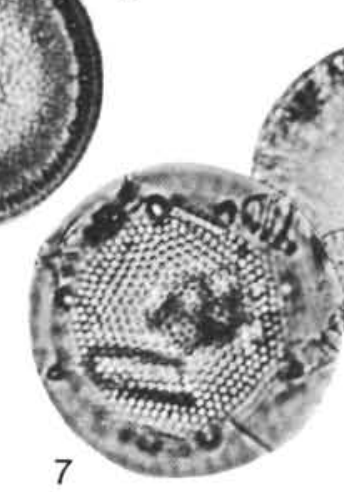

8

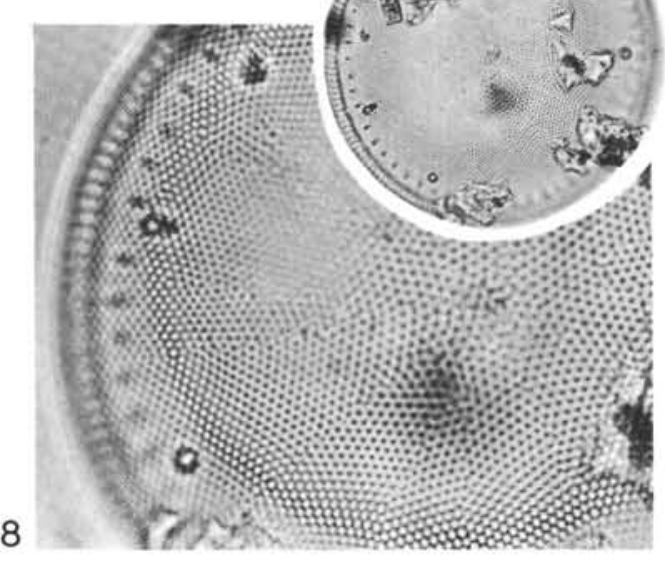

Plate 11. (Magnification $\times 1500$.) 1, 5. Thalassiosira cf. jacksonii Koizumi and Barron, (1) Sample 584-45,CC, (5) Sample 584-21,CC. 2. Thalassiosira jacksonii Koizumi and Barron, Sample 584-32,CC. 3-4. Thalassiosira sp. E, Sample 583-4-1, 47-48 cm. 6, 9. Thalassiosira sp. B, (6) Sample JDS-11685, Atsunai Formation, Atsunai Area, eastern Hokkaido, (9) Sample 438A-44,CC. 7. Thalassiosira sp. C, Sample 584-3,CC. 8. Thalassiosira sp. D, Sample $584-1-1,0-3 \mathrm{~cm}$. 

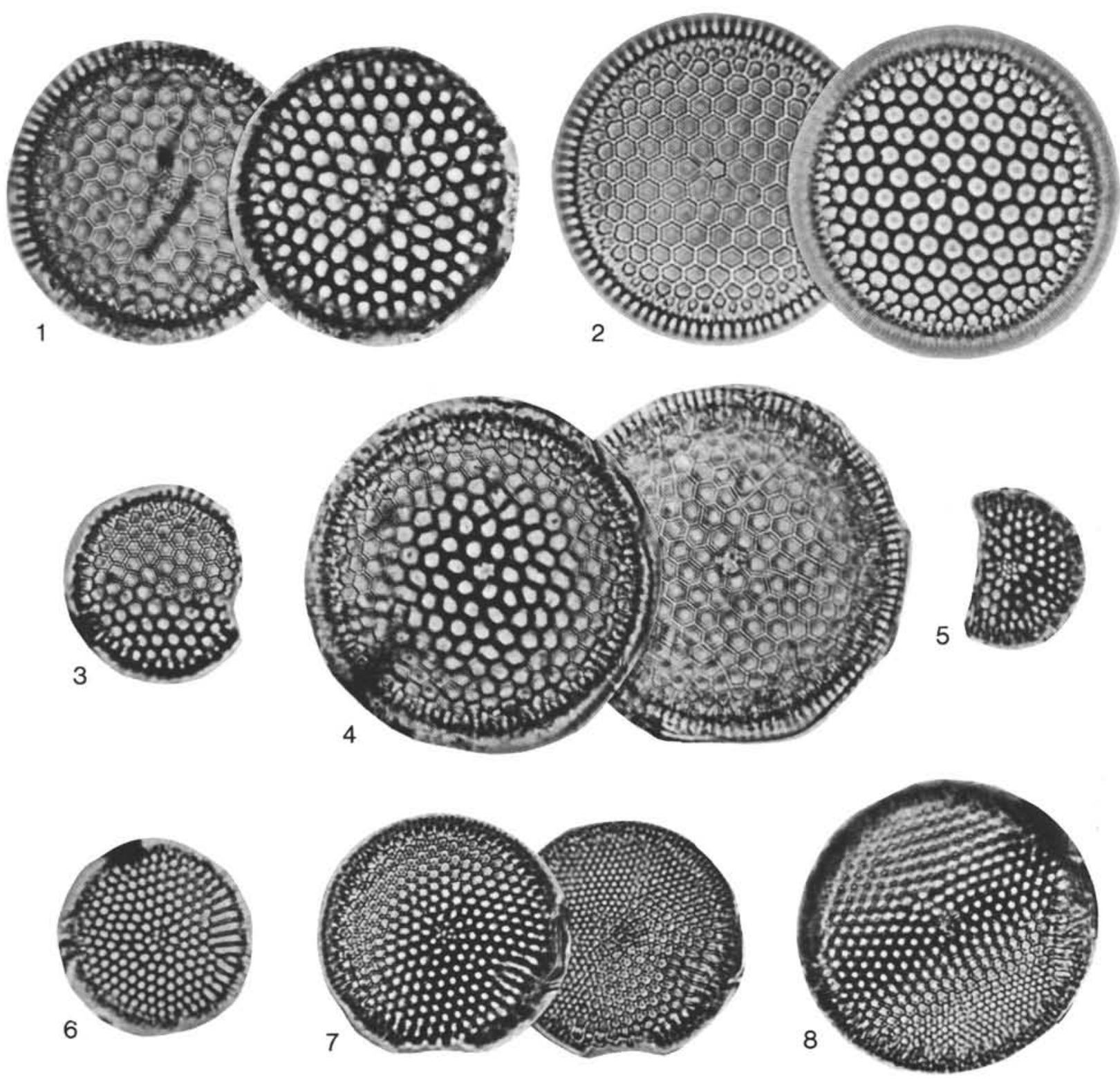

Plate 12. (Magnification $\times 1500$.) 1, 3-4. Thalassiosira antiqua (Grunow) Cleve-Euler, (1) Sample 584-33,CC, (3) Sample 438A-41,CC, (4) Sample 584-10,CC. 2. Thalassiosira sp. F, Sample 583-10-1, 116-117 cm. 5. Thalassiosira burckliana Schrader, Sample 584-63-2, 123-124 cm. 6-8. Thalassiosira singularis Sheshukova-Poretzkaya, (6) Sample "Calcaire de Sendai", (7, 8) Sample 438A-42-1, 90-91 cm. 

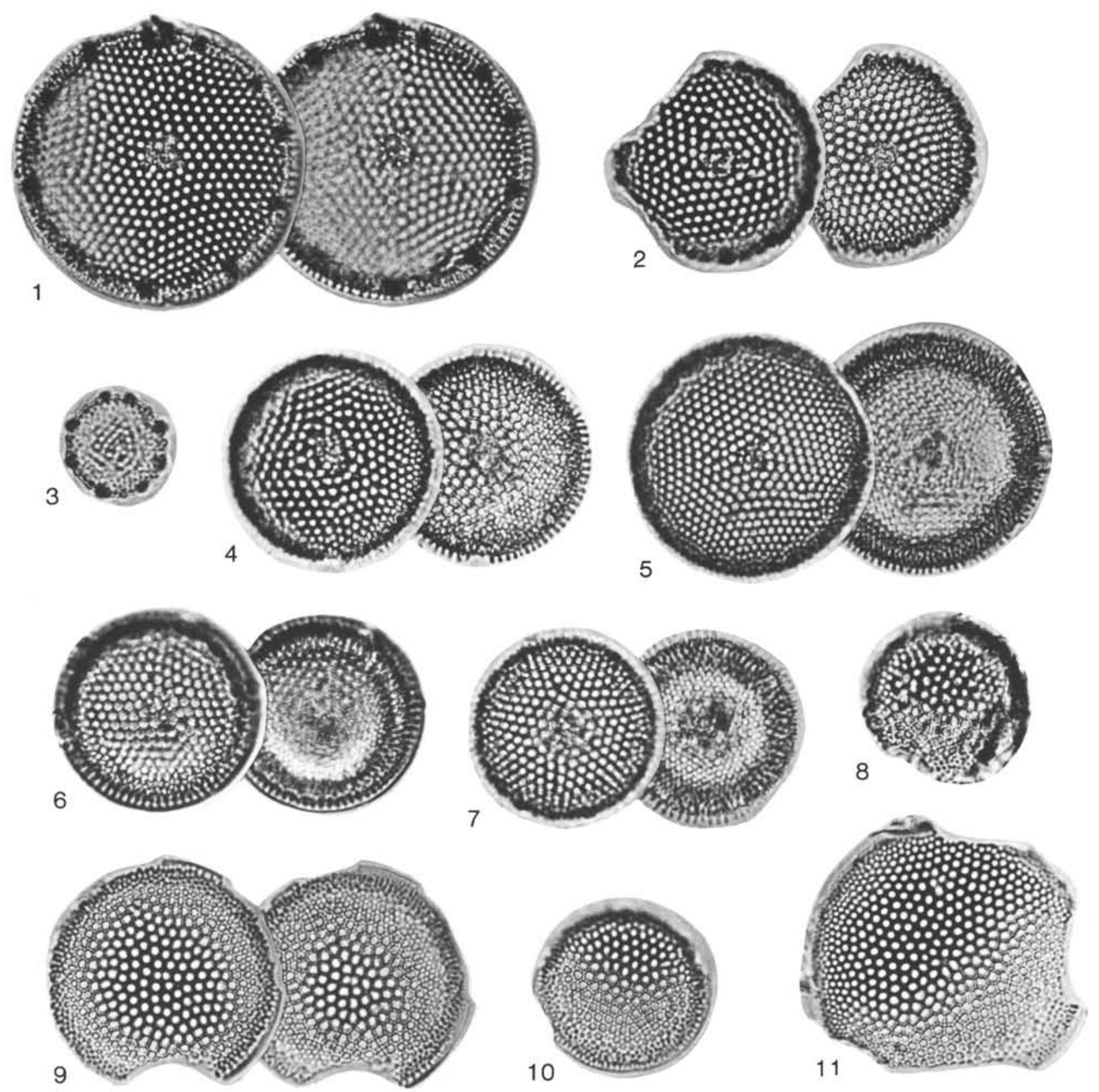

Plate 13. (Magnification $\times 1500$.) 1-7. Thalassiosira marujamica Sheshukova-Poretzkaya, (1-2, 5) Sample 584-54,CC, (3-4, 6-7) Sample 438A-42-4, 73-74 cm. 8-11. Thalassiosira umaoiensis Akiba n. sp., (8) Sample 439-10-4, 29-30 cm, (9-11) Sample JDS-12507, Yuni Formation, Umaoiyama Area, central Hokkaido, (9, holotype). 

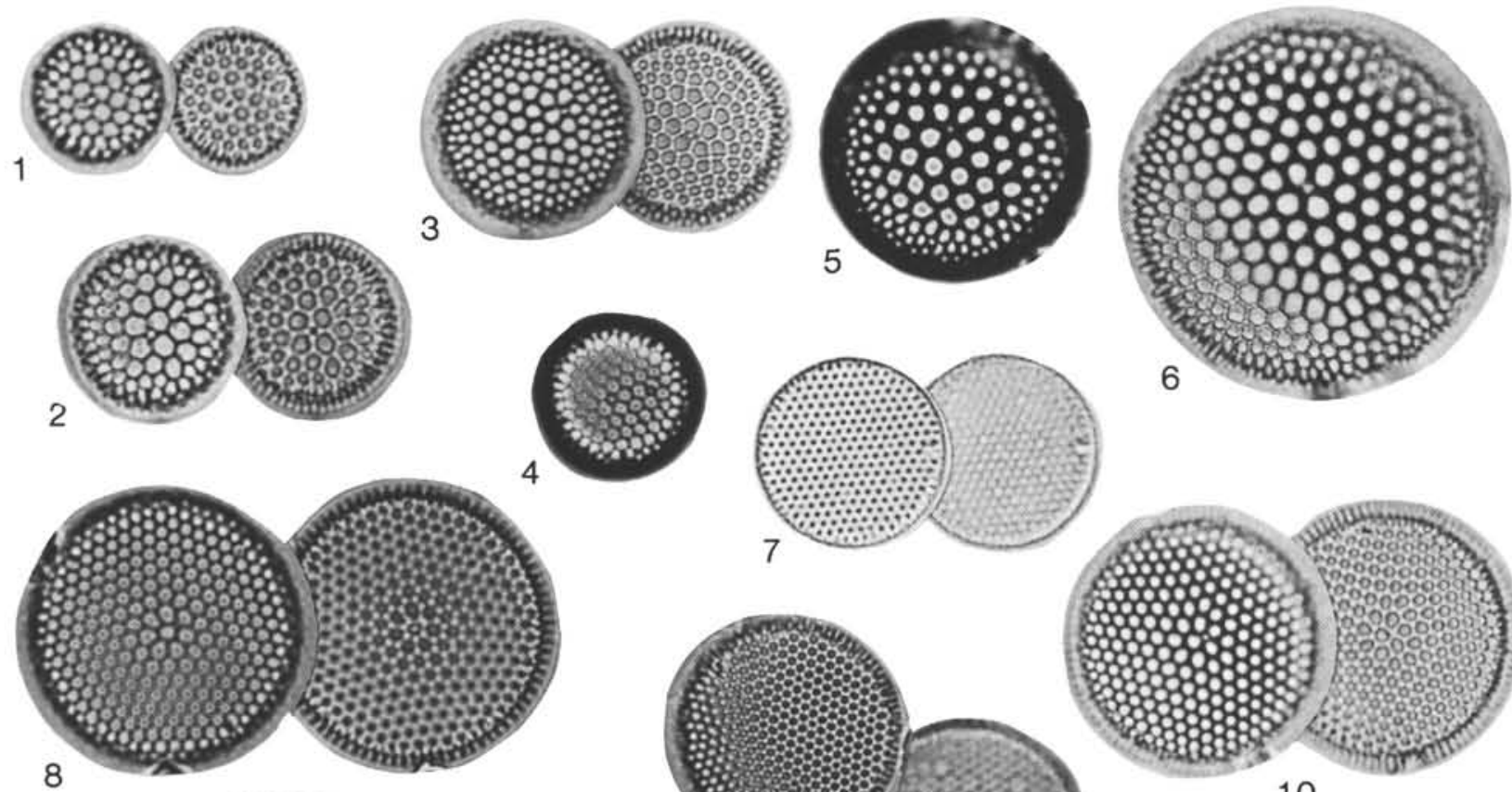

6
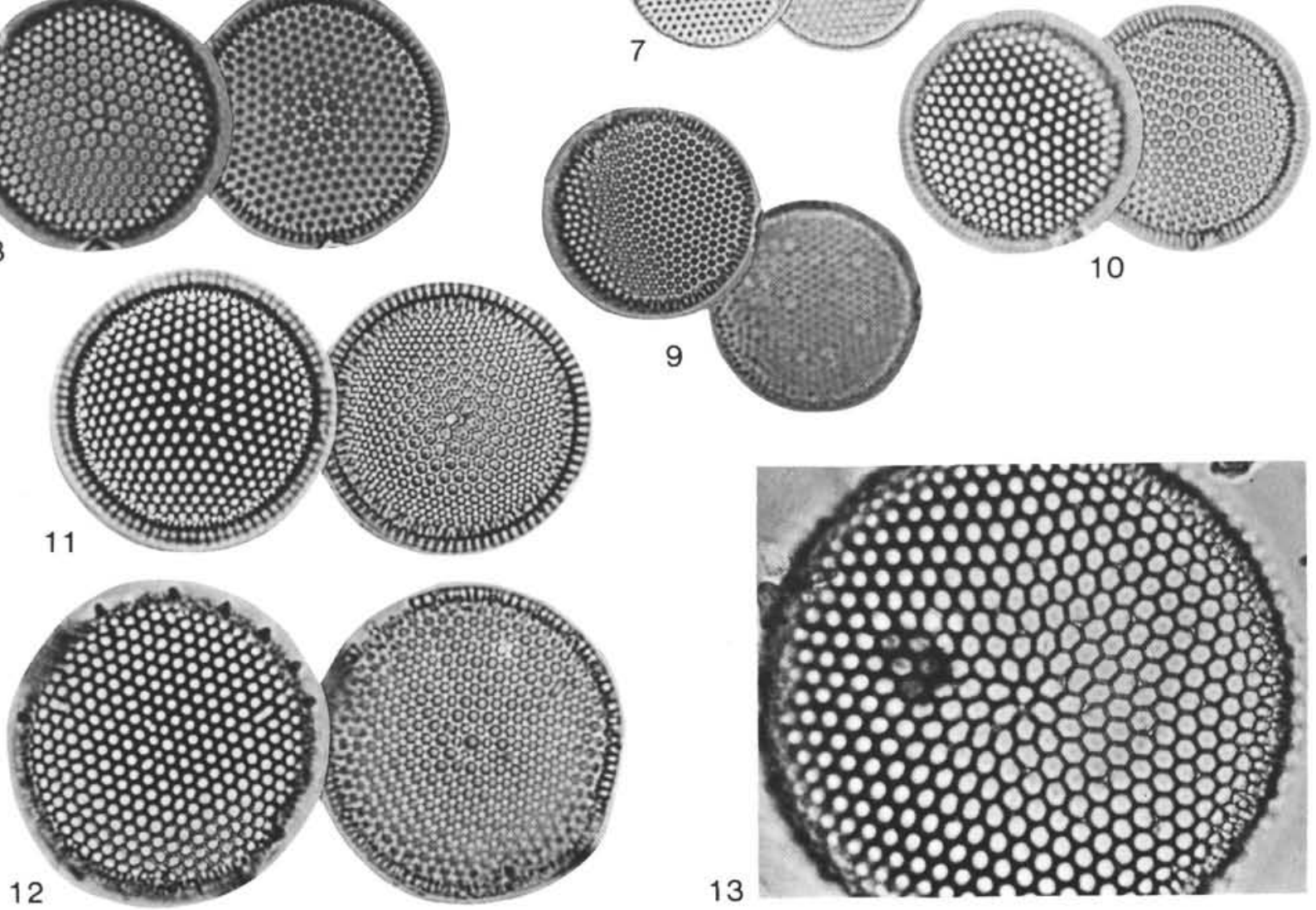

Plate 14. (Magnification $\times 1500$.) 1-6. Thalassiosira oestrupii (Ostenfeld) Proshkina-Labrenko, (1, 3, 6) Sample 584-1-1, 0-3 cm, (2) Sample 583-10-1, 116-117 cm, (4-5) Sample 583-4-1, 47-48 cm. 7, 9. Thalassiosira lineata Jousé, (7) Sample 584-1-1, 83-85 cm, (9) Sample 583-4-1, $47-48 \mathrm{~cm}$. 8. Planktoniella sol (Wallich) Schütt, Sample 583-4-1, 47-48 cm. 10-11. Thalassiosira cf. eccentrica (Ehrenberg) Cleve, (10) Sample 584-1-1, 0-3 cm, (11) Sample 584-21,CC. 12. Thalassiosira leptopus (Grunow) Hasle and Fryxell, Sample 438A-41,CC. 13. Thalassiosira eccentrica (Ehrenberg) Cleve, Sample 584-1-1, 0-3 cm. 

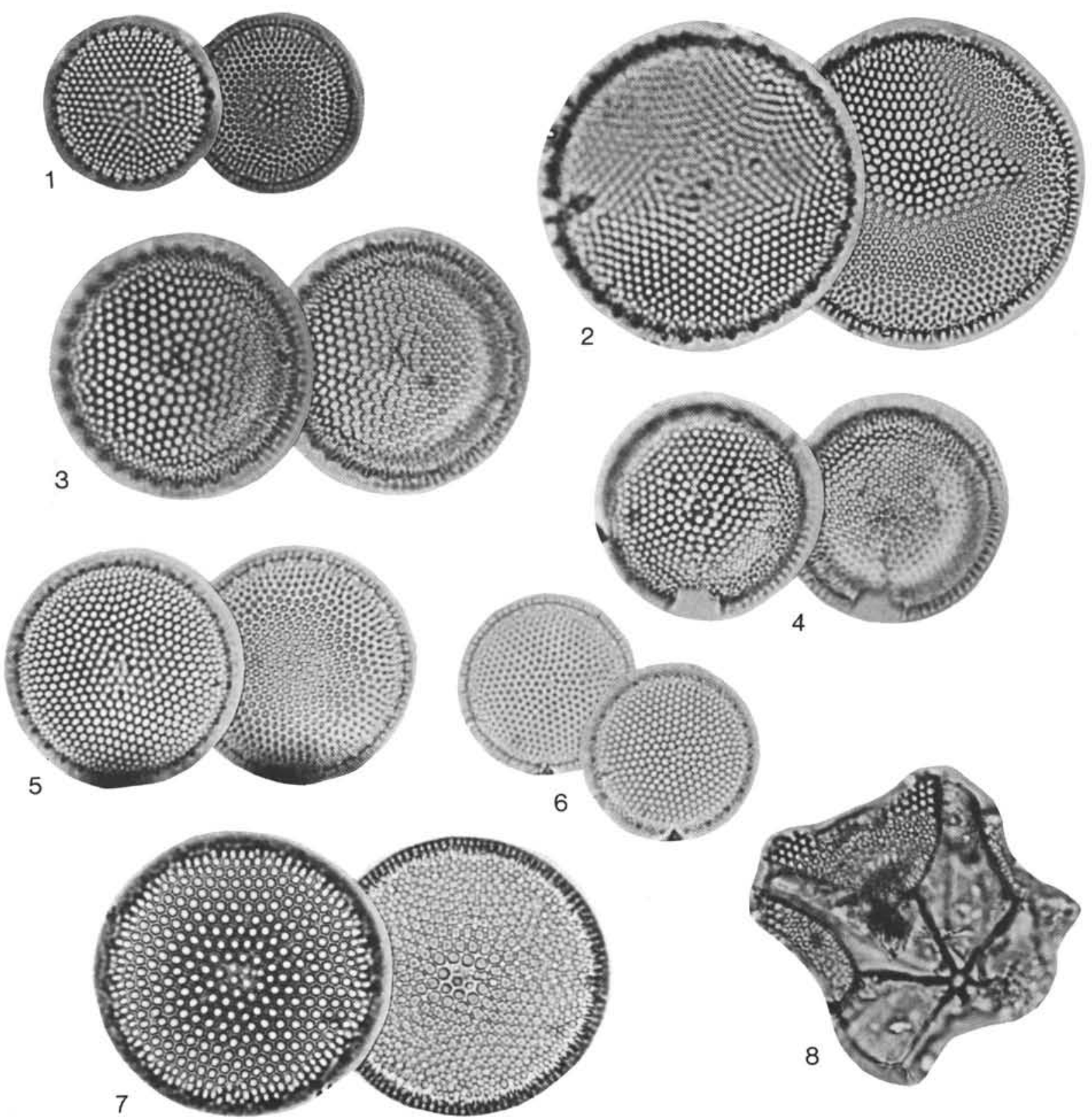

Plate 15. (Magnification $\times 1500$.) 1. Thalassiosira sp., Sample $583-4-1,47-48 \mathrm{~cm}$. 2. Thalassiosira aff. eccentrica (Ehrenberg) Cleve, Sample 583-4-1, 47-48 cm. 3-4. Thalassiosira aff. marujamica Sheshukova-Poretzkaya, (3) Sample 183-17-2, 80-82 cm, (4) Sample 183-17-4, 80-82 cm. 5-6. Thalassiosira cf. decipiens (Grunow) Joergensen, Sample 584-1-1, 0-3 cm. 7. Thalassiosira ? sp., Sample 584-1-1, 0-3 cm. 8. Asterolampra acutiloba Forti, Sample 584-56,CC. 


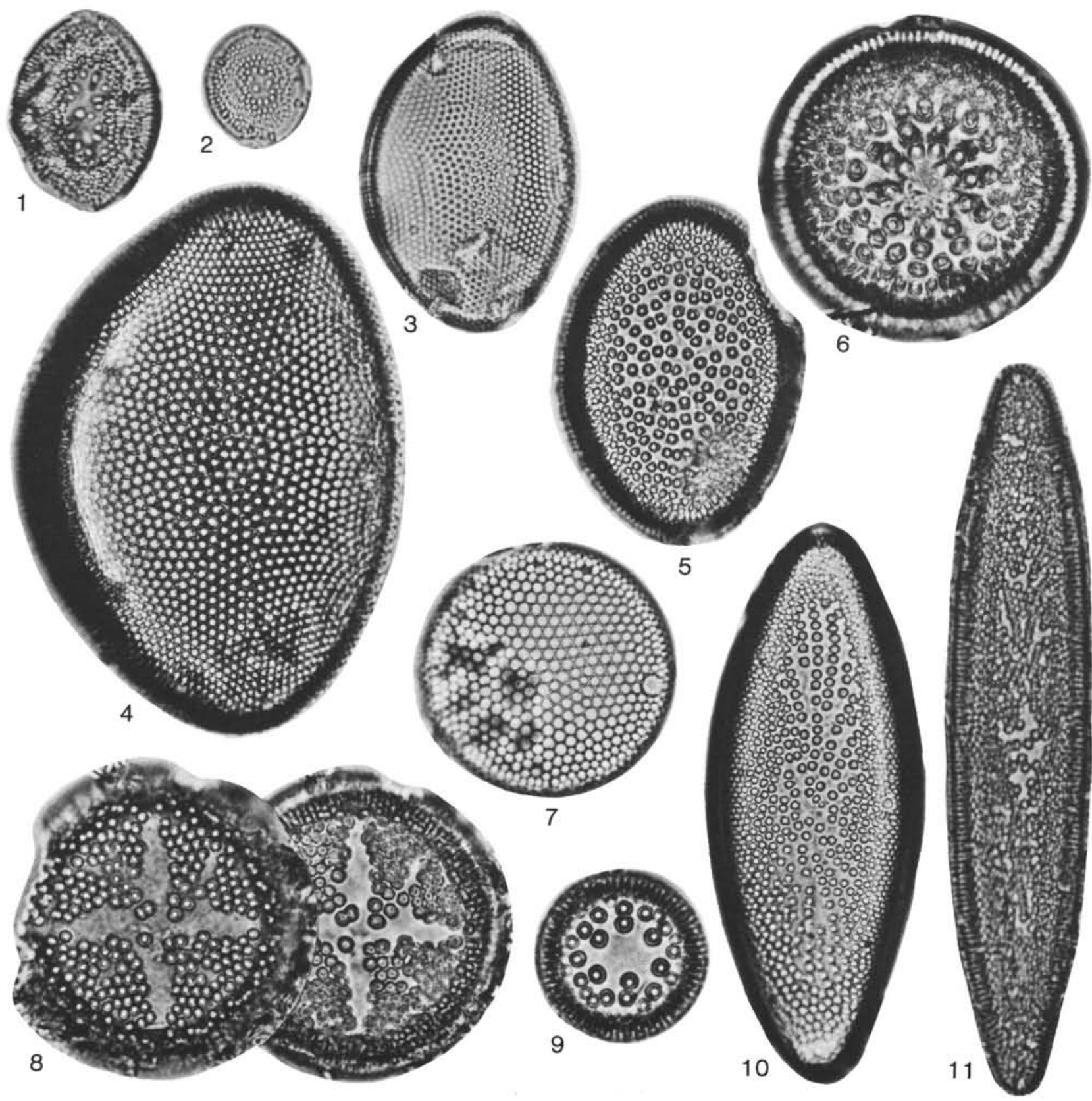

Plate 16. (Magnification $\times 1500$.) 1-2. Hemidiscus ovalis Lohman, (1) Sample 584-27,CC, (2) Sample 584-10,CC. 3-4. Hemidiscus cuneiformis Wallich, (3) Sample 584-1-1, 83-85 cm, (4) Sample 438A-48-7, 30-31 cm. 5. Actinocyclus ellipticus Grunow, Sample 438A-60-3, 26-27 cm. 6, 9. Actinocyclus ingens Rattray, (6) Sample 438A-60-3, 26-27 cm, (9) Sample 183-18,CC. 7. Roperia tesselata (Roper) Grunow, Sample 584-1-1, 0-3 cm. 8. Actinocyclus sp. A, Sample 439-17-3, 12-13 cm. 10. Actinocyclus ellipticus f. lanceolata Kolbe, Sample 438A-41,CC. 11. Actinocyclus ellipticus var. elongatus (Grunow) Kolbe, Sample 584-43,CC. 

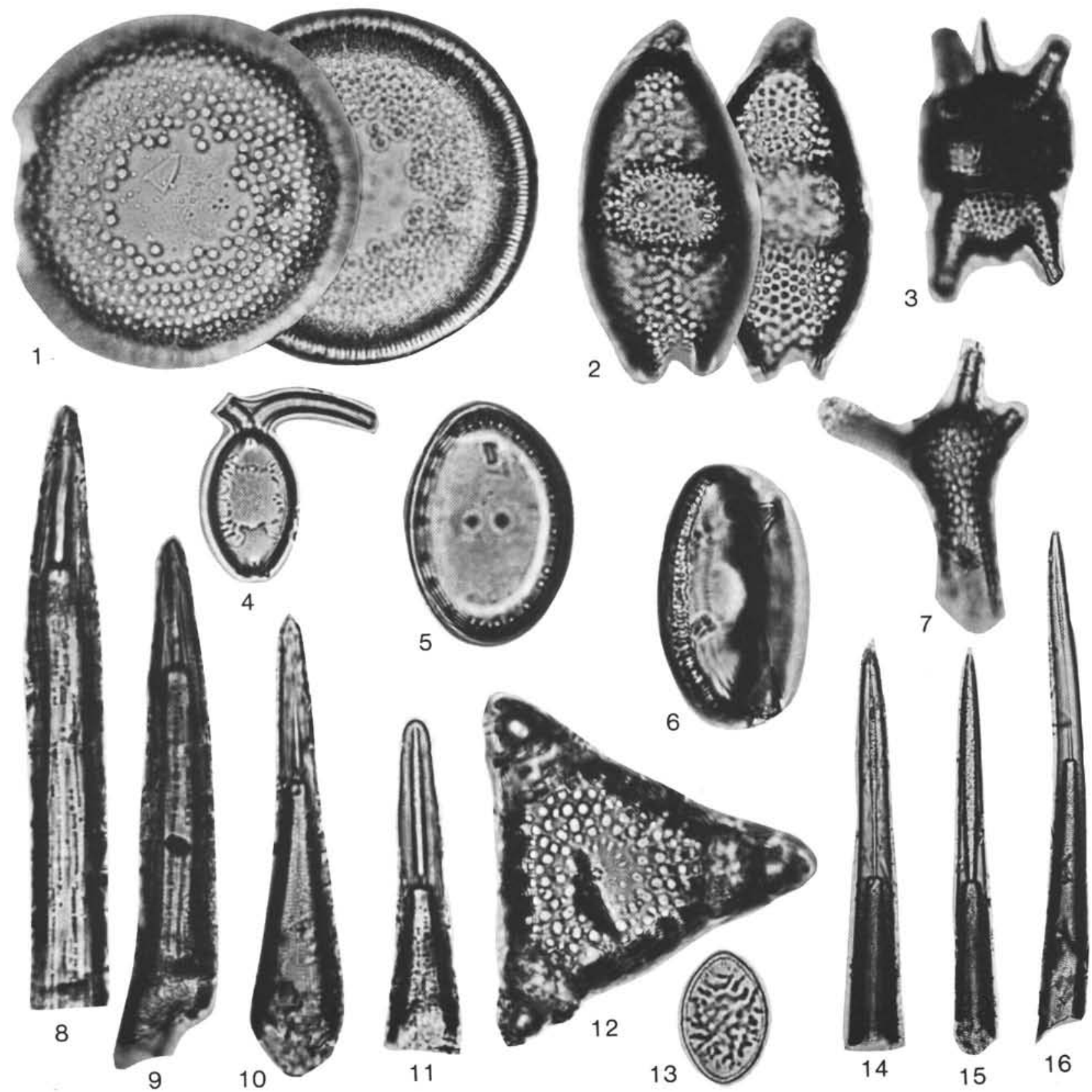

Plate 17. (Magnification $\times 1500$; Figs. $14-16, \times 600$.) 1. Cosmiodiscus insignis Jousé, Sample 438A-41,CC. 2-3. Odontella aurita (lyngbye) Agardh, Sample 438A-42-2, 95-96 cm. 4-6, 13. Chaetoceros spp. (resting spores), Sample 438A-42,CC. 7. Genus et species indet. sp. 2, Sample 584-31,CC. 8-9. Rhizosolenia sp. A, (8) Sample 584-6,CC, (9) Sample 584A-X1,CC. 10-11. Rhizosolenia cf. hebetata f. hiemalis Gran, Sample 584-43,CC. 12. Lithodesmium reynoldsii Barron, Sample 438A-42,CC. 14-16. Rhizosolenia sp., (14, 16) Sample 584-6,CC, (15) Sample 584-1-3, 20-21 cm. 


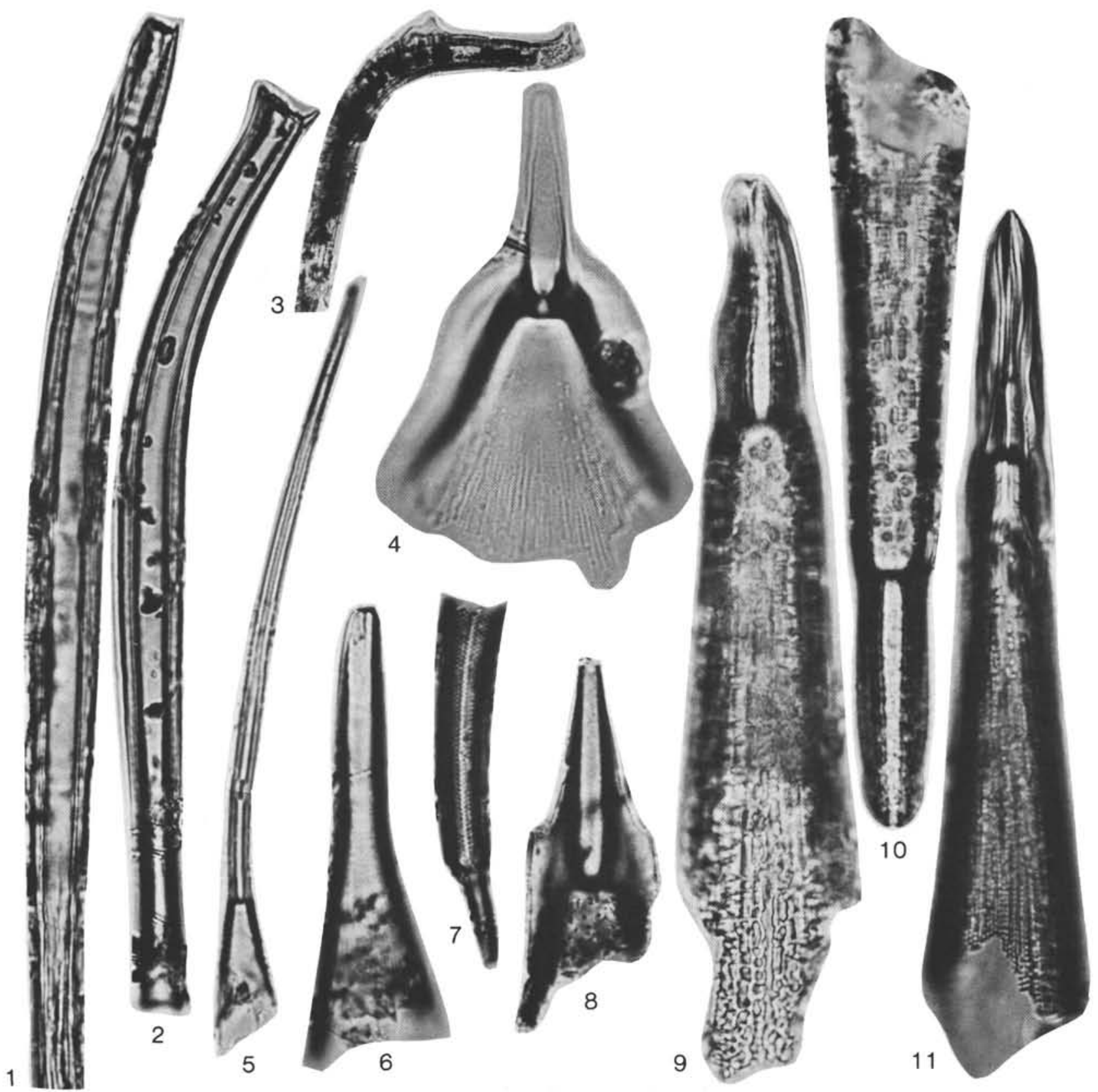

Plate 18. (Magnification $\times 1500$; Figs. 3, 5, $\times 600$.) 1. Rhizosolenia praebarboi Schrader, Sample JDS-11193, Mito Formation, Mito City, northeastern Honshu. 2. Rhizosolenia barboi (Brun) Tempère and Peragallo, Sample 438A-60-3, 26-27 cm. 3. Rhizosolenia curvirostris Jousé, Sample JDS-12711, dredge material, off Otsuchi, northeastern Honshu. 4. Rhizosolenia styliformis Brightwell, Sample 582-1-1, 34-36 cm. 5. Rhizosolenia setigera Brightwell, Sample 584-34,CC. 6. Rhizosolenia alata Brightwell, Sample 584-34,CC. 7. Rhizosolenia miocenica Schrader, Sample 438A-53-2, 30-31 cm. 8. Rhizosolenia cf. hebetata f. semispina (Hensen) Gran, Sample 584-7, CC. 9. Rhizosolenia hebetata f. hiemalis Gran, asymmetric form, Sample $584-1-1,83-85 \mathrm{~cm}$. 10. Rhizosolenia hebetata $\mathrm{f}$. hiemalis Gran, Sample 584-1-1, 83-85 cm. 11. Rhizosolenia sp. A, Sample 438A-42-4, 73-74 cm. 

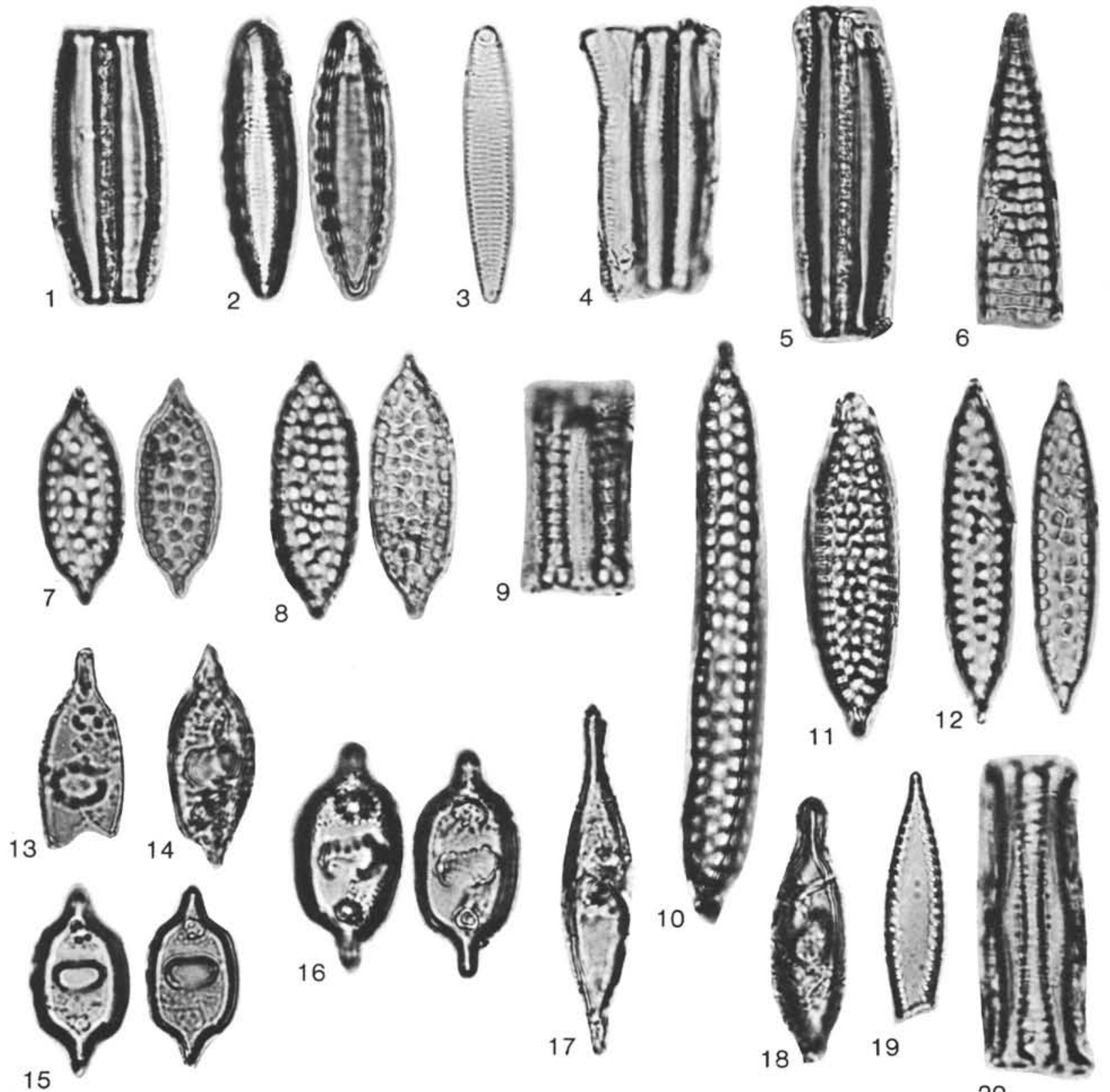

Plate 19. (Magnification $\times 1500$.) 1-5. Ikebea tenuis (Brun) Akiba, $\mathrm{n}$. comb., (1-2) Sample 438A-60-3, 26-27 cm, (3-4) Sample JDS-10648, Hata Formation, Boso Peninsula, central Japan, (5) Sample 584-54,CC, (3) vegetative valve of "kannoa" type, (4) colony of vegetative cell and resting spore. 6. Rossiella praepaleacea (Schrader) Gersonde and Schrader, Sample 438A-43,CC. 7-9. Rossiella tatsunokuchiensis (Koizumi) Gersonde and Schrader, (7) Sample 584-11,CC, (8) Sample 584-21,CC, (9) Sample 584-12,CC, 10-12. Rossiella cf. tatsunokuchiensis (Koizumi) Gersonde and Schrader, (10) Sample 438A-42-4, 73-74 cm, (11) Sample 584-21,CC, (12) Sample 584-10,CC. 13-16. Kisseleviella ezoensis Akiba n. sp., (13-14) Sample 439-17-3, 12-13 cm, (15-16) Sample JDS-8482, Tokomuro Formation, Atsunai Area, eastern Hokkaido, (16) holotype. 17-18. Kisseleviella carina Sheshukova-Poretzkaya, Sample 439-8-6, 49-52 cm. 19-20. Cymatosira debyi Tempère and Brun, (19) Sample $584-35, C C,(20)$ Sample $584-46, C$, colony in girdle view. 


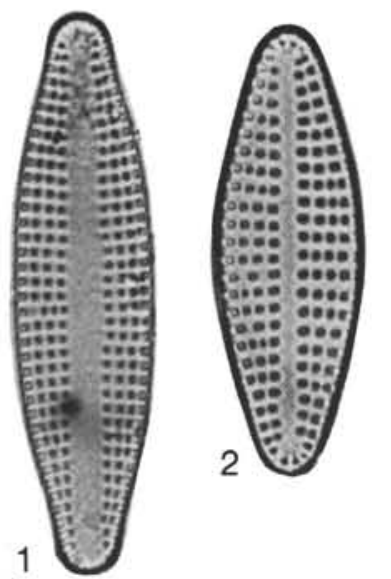

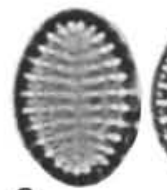

8

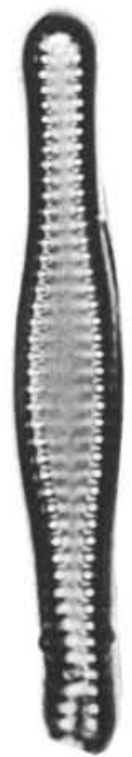

12
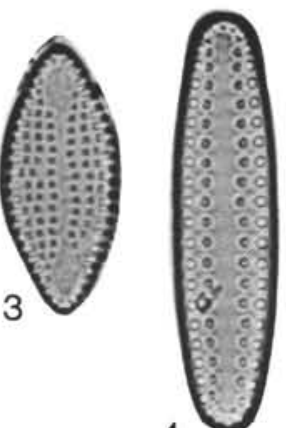

4
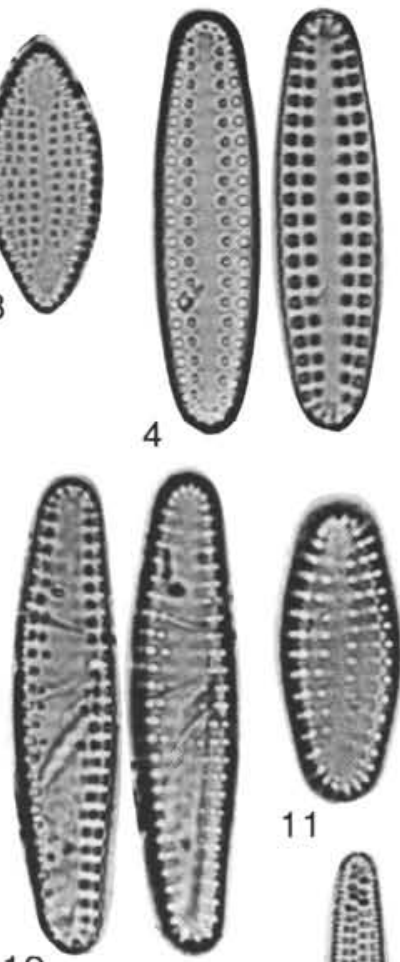

11

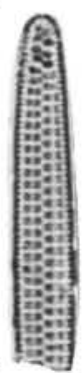

14

15

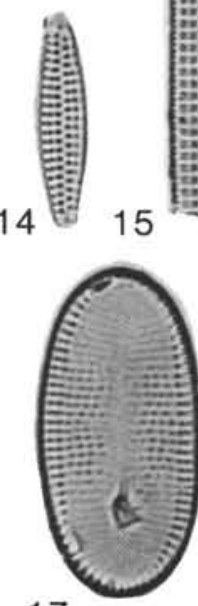

17

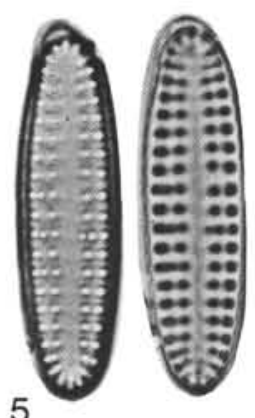

5
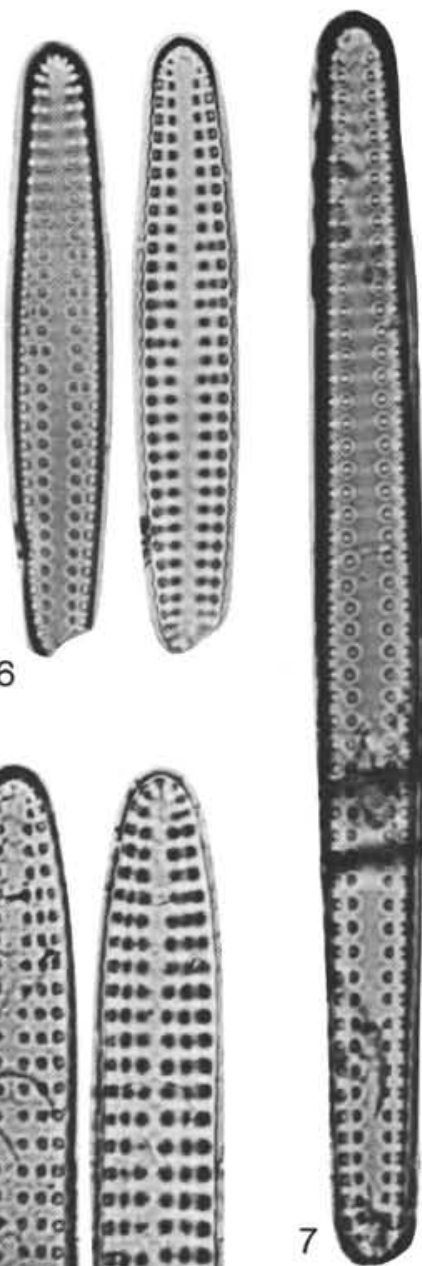

16
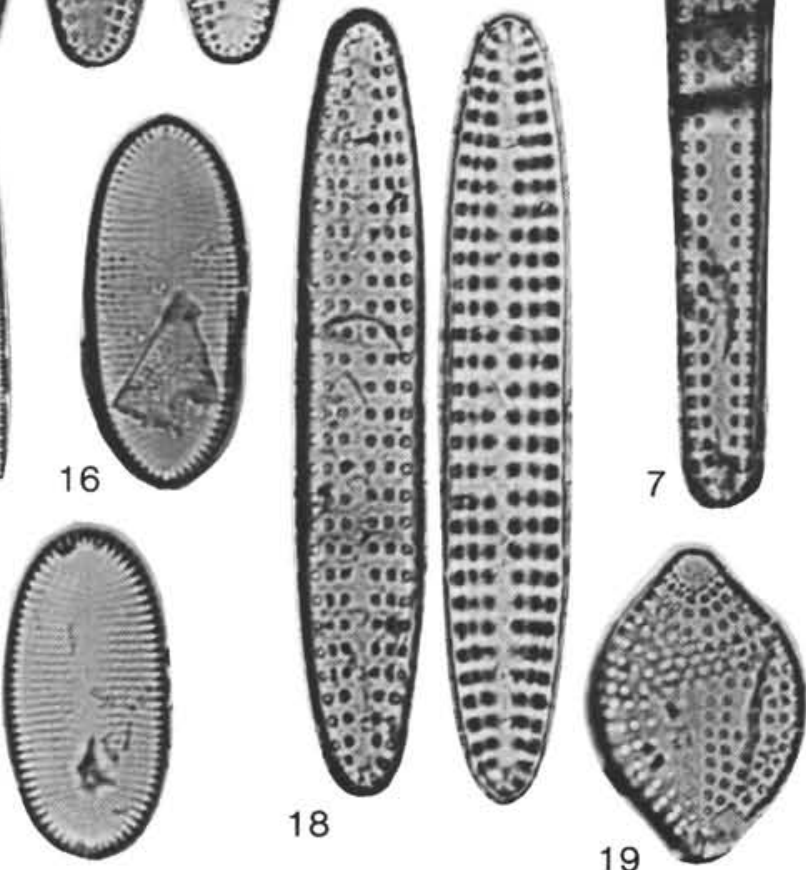

Plate 20. (Magnification $\times 1500$.) 1. Delphineis kippae Sancetta, Sample 584A-H1-3, 121-123 cm. 2-3. Delphineis surirella (Ehrenberg) Andrews, Sample 584-4,CC. 4-7. Delphineis cf. angustata (Pantocsek) Andrews, (4, 7) Sample 584-4,CC, (5-6) Sample 438A-41, CC. 8-9. Rhaphoneis $\mathrm{cf}$. ischaboensis (Grunow) Mertz, short form, (8) Sample 584-9,CC, (9) Sample 584-10,CC. 10-11. Rhaphoneis cf. ischaboensis (Grunow) Mertz, (10) Sample 584-23,CC, (11) Sample 584-21,CC. 12-13. Delphineis simonsenii (Mertz) Akiba n. comb., Sample 584-21,CC. 14-15. Neodelphineis pelagica Takano, (14) Sample 438A-43,CC, (15) Sample 584-3,CC. 16-17. Delphineis sheshukovae Akiba n. sp., Sample 584-32,CC, (17) holotype. 18. Rhaphoneis cf. sachalinensis Sheshukova-Poretzkaya, Sample 584-3,CC. 19. Rhaphoneis amphiceros Ehrenberg, Sample 584-10,CC. 


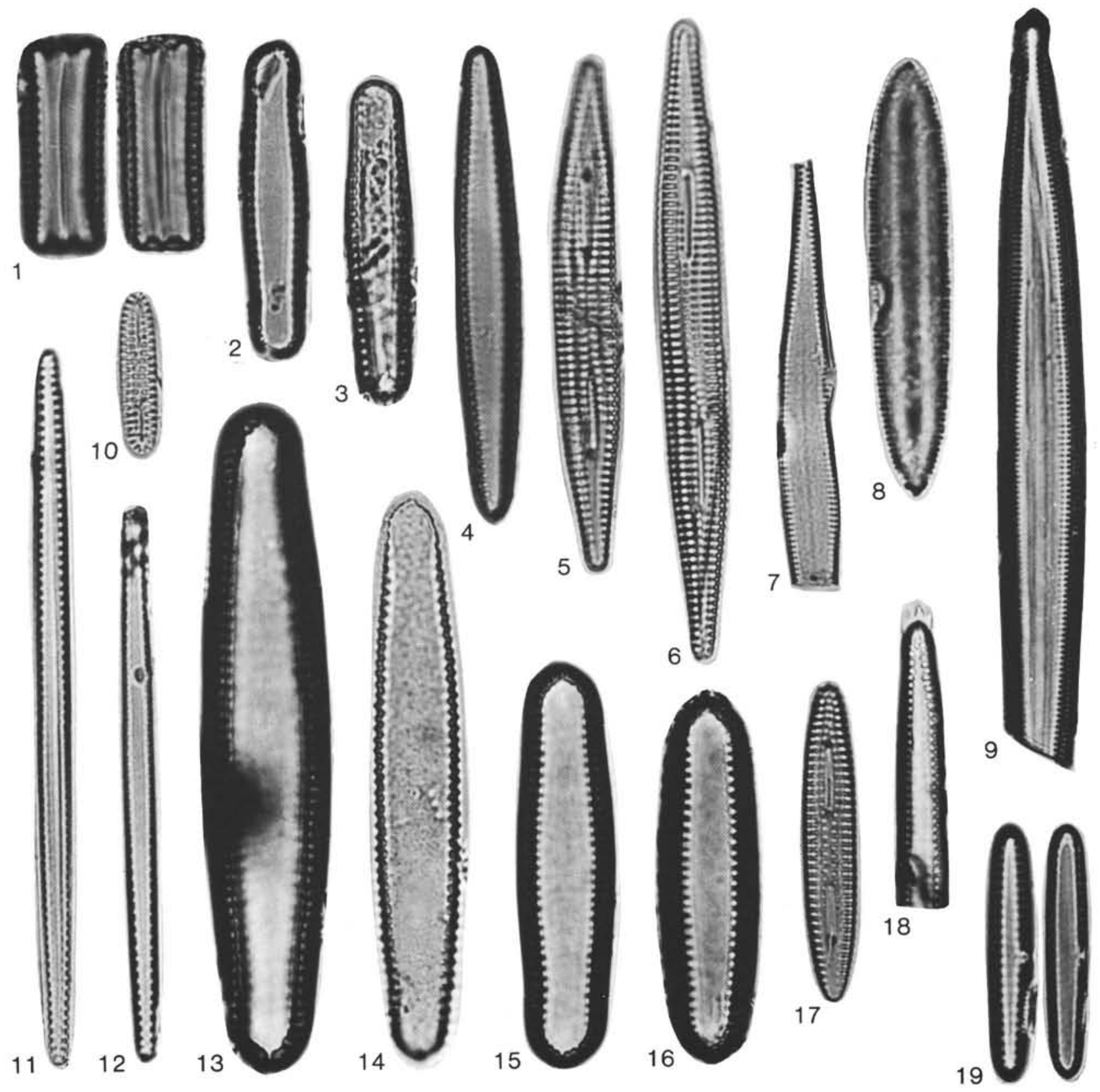

Plate 21. (Magnification $\times 1500$.) 1-3. Thalassionema hirosakiensis (Kanaya) Schrader, (1) Sample 584-71,CC, (2-3) Sample 438A-60-3, 26-27 cm. 4. Thalassiothrix robusta (Schrader) Akiba n. comb., Sample JDS-2289, Koetoi Formation, Tenpoku Area, northern Hokkaido. 5-6. Rouxia californica M. Peragallo, Sample 438A-42-2, $95-96 \mathrm{~cm}$. 7. Synedra miocenica Schrader, Sample 438A-56, CC. 8. Synedra jouseana f. linearis Sheshukova-Poretzkaya, Sample 183-18-2, 80-82 cm. 9. Synedra jouseana Sheshukova-Poretzkaya, Sample 438A-42,CC. 10. Rouxia cf. diploneides Schrader, Sample 438A-66-2, 82-84 cm. 11. Thalassionema nitzschioides (Grunow) H. and M. Peragallo, Sample 584-1-1, 83-85 cm. 12. Thalassionema bacillaris (Heiden) Kolbe, Sample 584-1-1, 83-85 cm. 13-16. Thalassionema schraderi Akiba, (13-15) Sample 183-18-3, 80-82 $\mathrm{cm}$, (14) valve without mantle, (16) Sample 438A-48-7, 30-31 cm. 17. Rouxia cf. peragalli Brun and Héribaud, Sample 438A-42-4, 73-74 cm. 18. Thalassiothrix longissima Cleve and Grunow, Sample 584-4,CC. 19. Thalassionema cf. nitzschioides (Grunow) H. and M. Peragallo, Sample $438 \mathrm{~A}-60-3,26-27 \mathrm{~cm}$. 

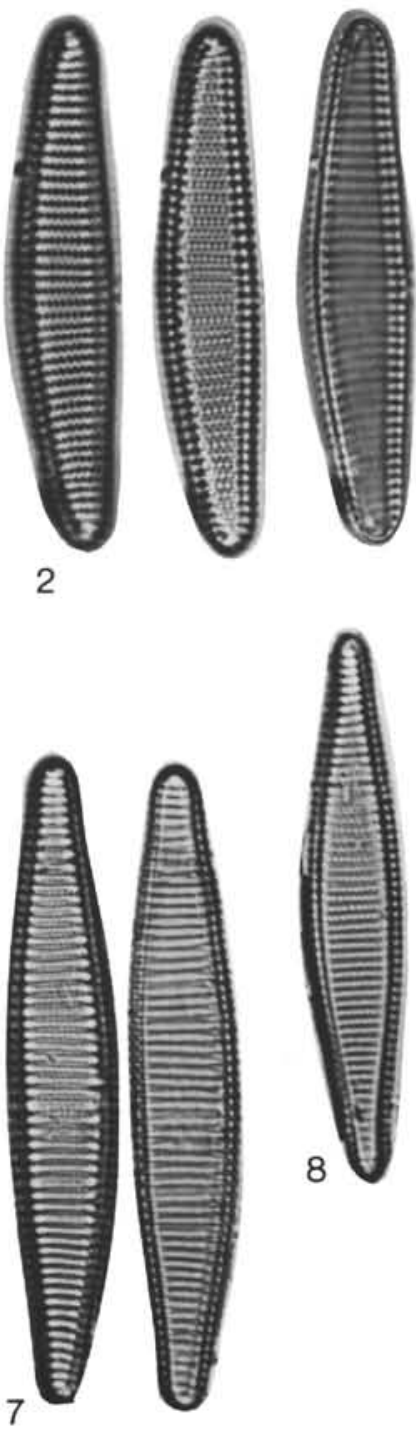
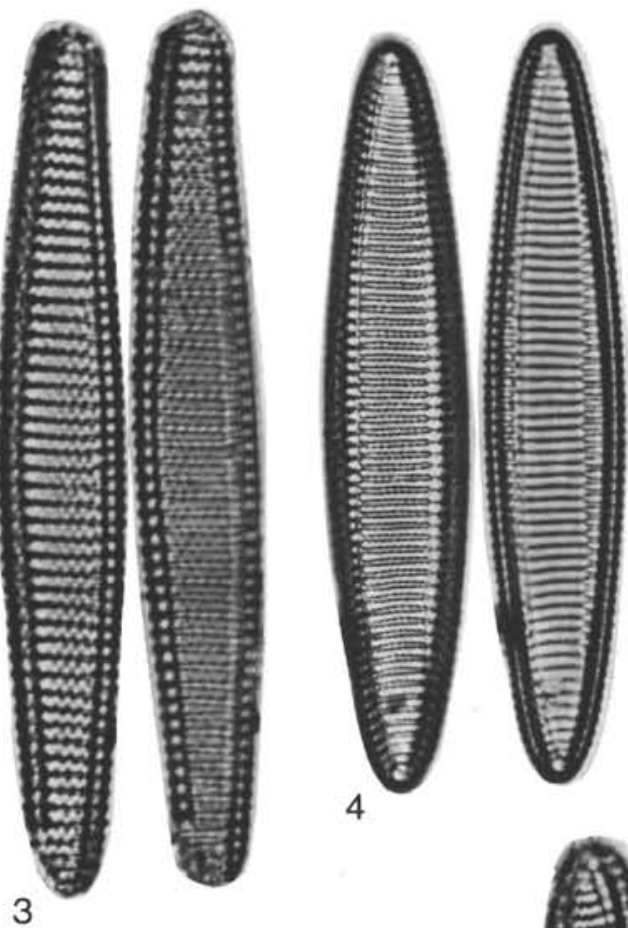

3
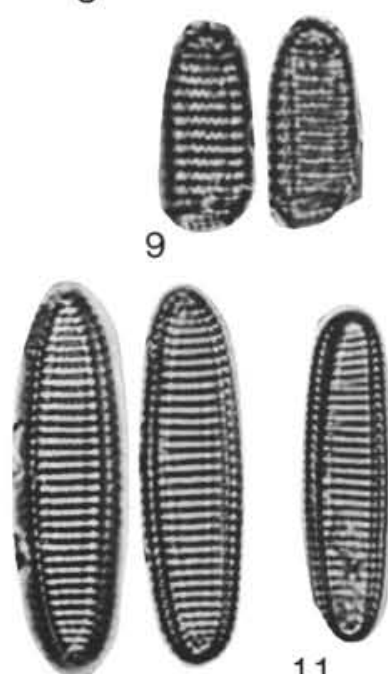

11

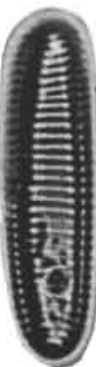

12

10

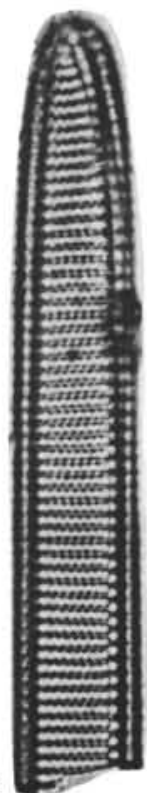

5

Plate 22. (Magnification $\times 1500$.) 1-2. Pseudoeunotia doliolus (Wallich) Grunow, (1) Sample 584A-H1-4, 100-101 cm, (2) Sample 583-4-1, 47-48 cm. 3. Nitzschia cf. fossilis (Frenguelli) Kanaya ex Schrader, Sample 584-33,CC. 4-5. Nitzschia reinholdii Kanaya ex Schrader, (4) Sample 438A-41,CC, (5) Sample 584-10,CC. 6-8. Nitzschia fossilis (Frenguelli) Kanaya ex Schrader, Sample 584-34,CC. 9. Nitzschia cf. cylindrica Burckle, Sample 438A-57-4, 125-127 cm. 10-11. Nitzschia sp., Sample 438A-48-7, 30-31 cm. 12. Nitzschia marina Grunow, Sample $584-4, C C$. 

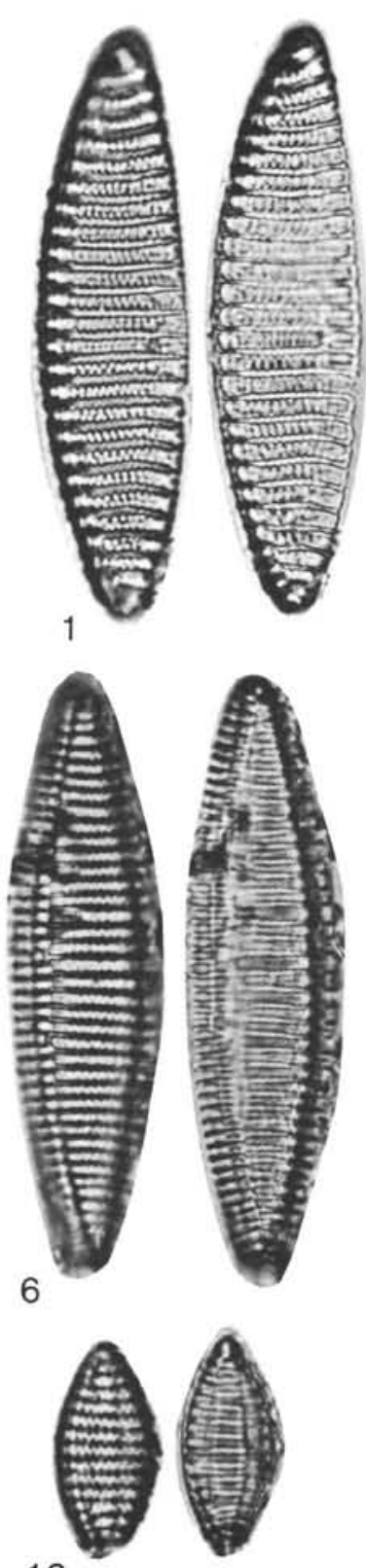

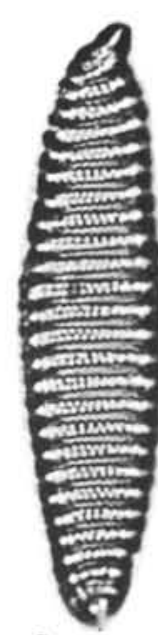

2
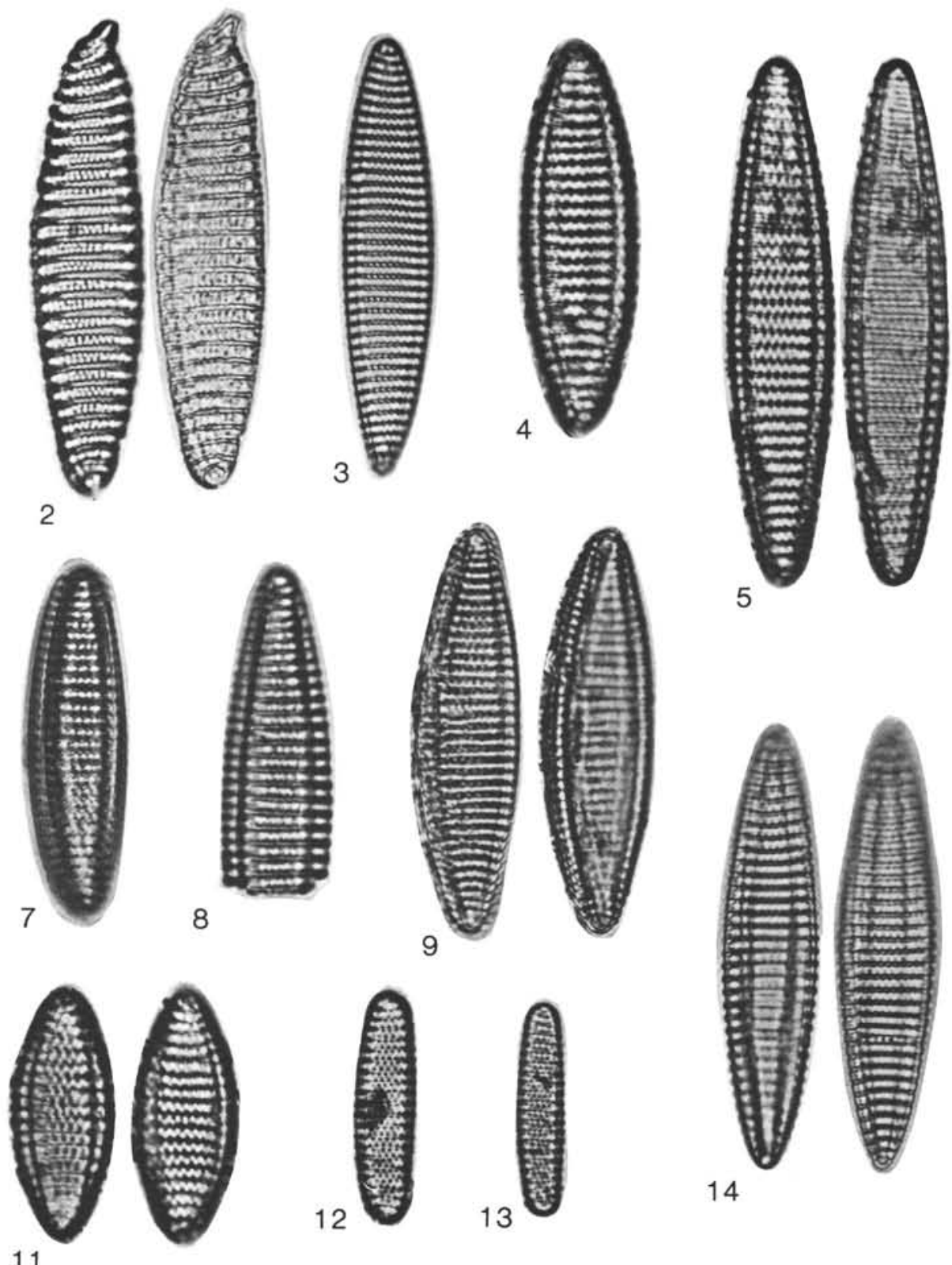

13
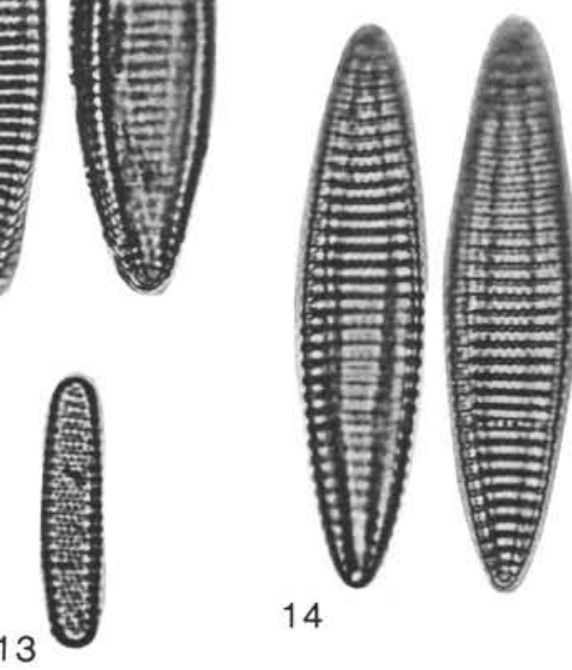

14

Plate 23. (Magnification $\times 1500$.) 1-2. Nitzschia umaoiensis Akiba n. sp., Sample JDS-3663, Yuni Formation, Umaoiyama Area, central Hokkaido,

(1) holotype. 3. Nitzschia heteropolica Schrader, Sample JDS-11685, Atsunai Formation, Atsunai Area, eastern Hokkaido. 4, 5, 11. Nitzschia jouseae Burckle, (4) Sample 584-25,CC, (5) Sample 584-6,CC, (11) Sample 584-30,CC. 6-9. Nitzschia pliocena (Brun) Mertz, (6) Sample 438A-42-5, 100-101 cm, (7) Sample 438A-42-4, 73-74 cm, (8) Sample 183-18-2, 80-82 cm, (9) Sample 584-61,CC. 10, 14. Nitzschia miocenica Burckle, Sample 438A-41,CC. 12-13. Nitzschia cf. cylindrica Burckle, (12) Sample 438A-44,CC, (13) Sample 438A-50-7, 10-11 cm. 

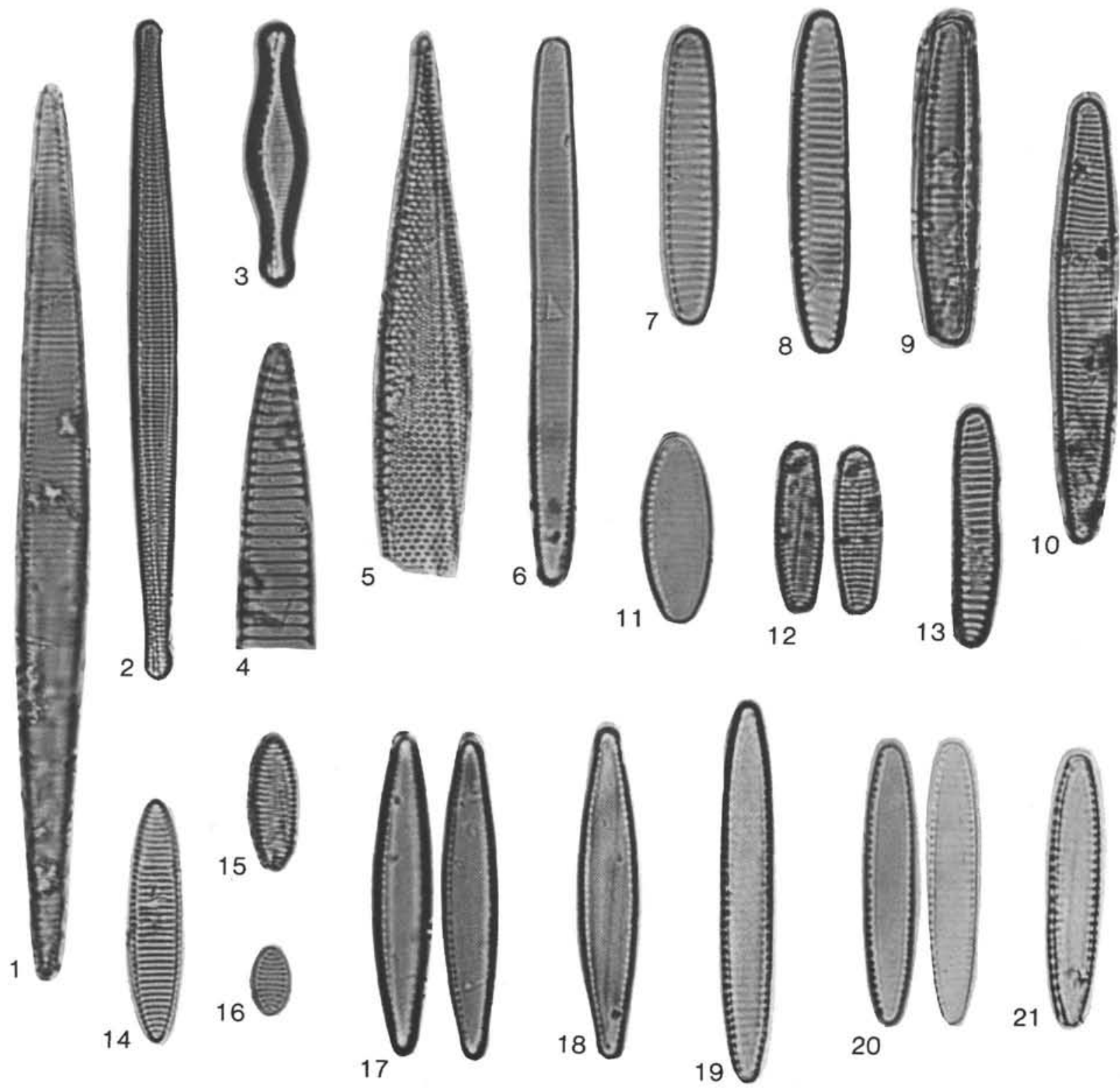

Plate 24. (Magnification $\times 1500$.) 1. Nitzschia cf. seriata Cleve, Sample 584-H1-3, 121-123 cm. 2. Nitzschia interruptestriata Simonsen, Sample 583-4-1, 47-48 cm. 3. Nitzschia capuluspalae Simonsen, Sample 583-4-1, 47-48 cm. 4. Nitzschia cf. sicula (Castracane) Hustedt, Sample 584-4,CC. 5. Nitzschia kolaczekii Grunow, Sample 584A-H1-3, 121-123 cm. 6-11. Nitzschia sp. 1 Group, (6-7, 11) Sample 584-4,CC, (8) Sample 584-9,CC, (9) Sample 439-10-4, 29-30 cm, (10) Sample 438A-52-7, 20-21 cm. 12. Nitzschia cf. challengeri Schrader, Sample 584-74,CC. 13. Nitzschia cf, rolandii Schrader emend. Koizumi, Sample 438A-44,CC. 14-16. Nitzschia cf. extincta Kozurenko and Sheshukova-Poretzkaya, $(14,16)$ Sample 584-4,CC, (15) Sample 584-34,CC. 17-18. Genus et species indet. sp. 1, (17) Sample 584-9,CC, (18) Sample 584-1-1, 0-3 cm. 19-21. Nitzschia grunowii Hasle, Sample $584-1-1,83-85 \mathrm{~cm}$. 

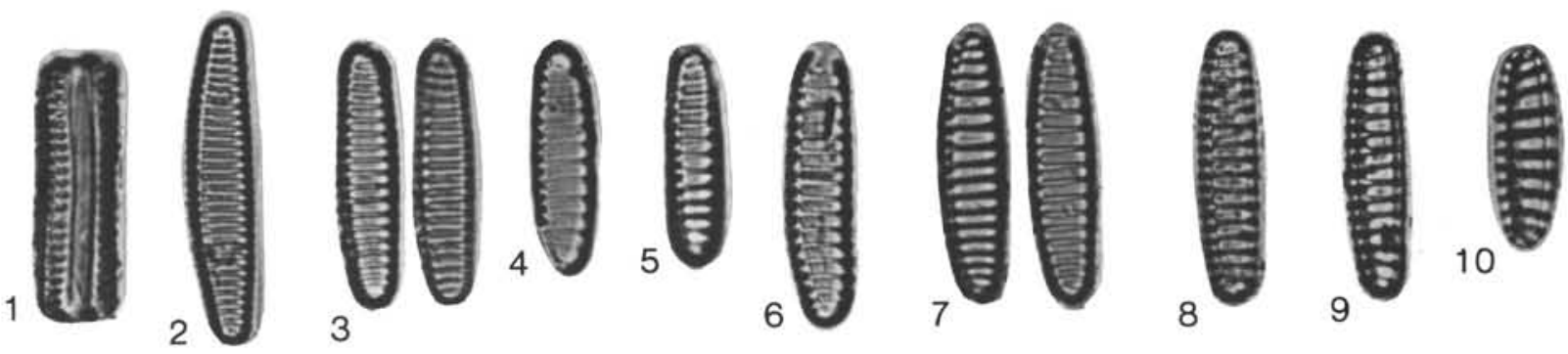

11

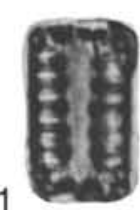

12

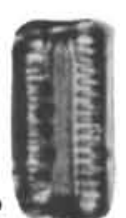

13

14
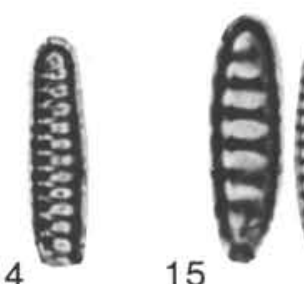

15

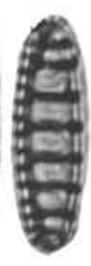

16
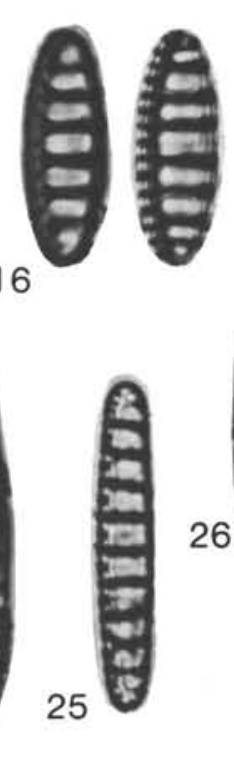

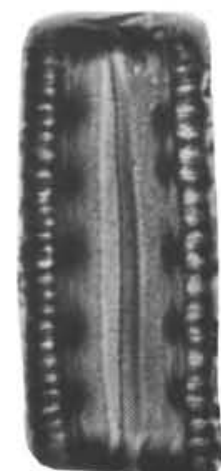

28

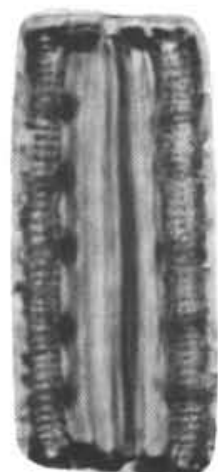

22
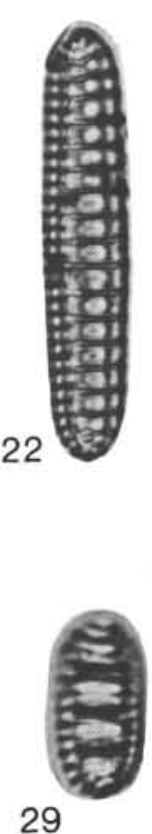
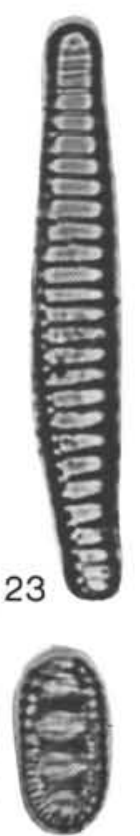

\section{0}
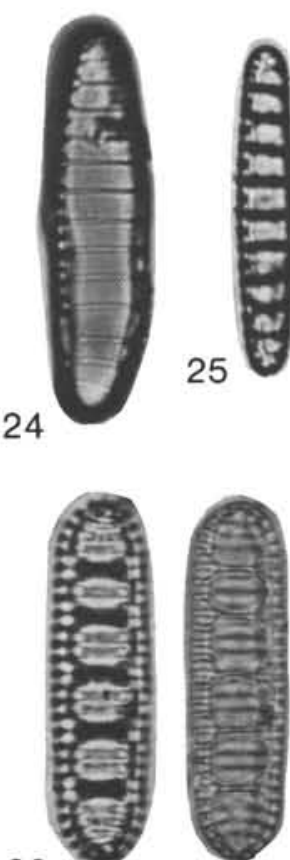

31

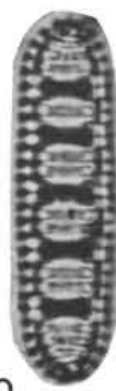

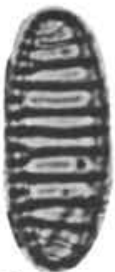

17

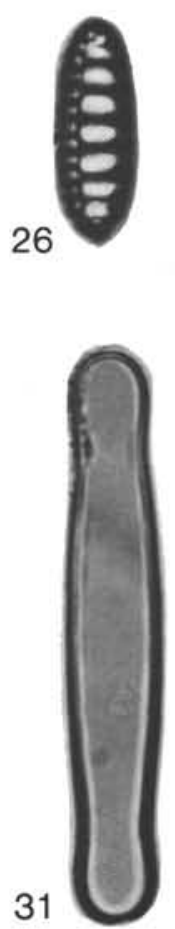

27
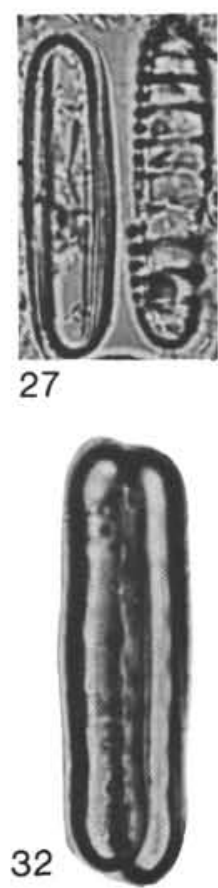

Plate 25. (Magnification $\times 1500$.) 1-6. Nitzschia rolandii Schrader emend. Koizumi, (1) Sample 438A-44,CC, (2) Sample 438A-53-2, 30-31 cm, (3) Sample 584-48,CC, (4, 6) Sample 584-55,CC, (5) Sample 438A-41,CC. 7-27. Neodenticula kamtschatica (Zabelina) Akiba and Yanagisawa, (7) Sample 584-54,CC, (8) Sample 438A-42-5, 100-101 cm, (9) Sample 438A-43,CC, (10) Sample 438A-42,CC, (11-12, 18-21, 26) Sample 584-4,CC, (13-14) Sample 584-60-1, 30-31 cm, (15-17, 22-25) Sample 584-10,CC, (27) Sample 584-1-3, 20-21 cm. 28-32. Neodenticula seminae (Simonsen and Kanaya) Akiba and Yanagisawa, (28) Sample 584A-H1-2, 100-101 cm, (29-31) Sample 584-1-1, 0-3 cm, (32) Sample 584A-H1-5, 100-101 cm, (31-32) isolated intercalary band. 

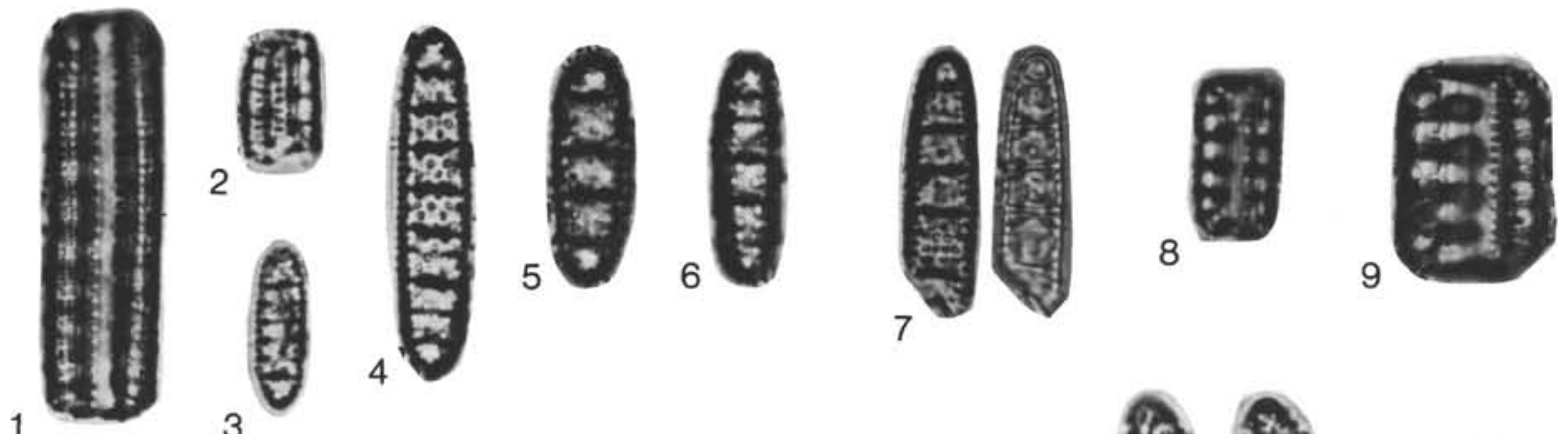

3

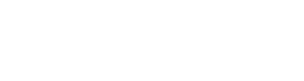

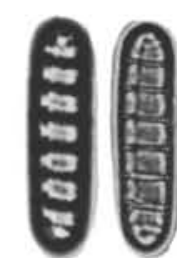

10

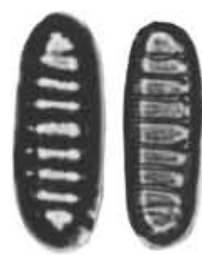

11

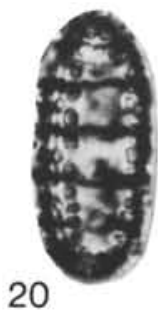

21

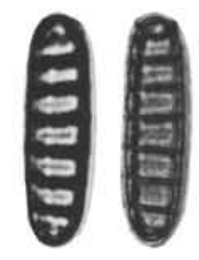

13

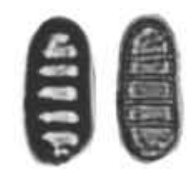

12

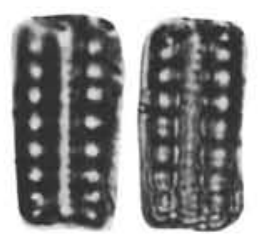

14

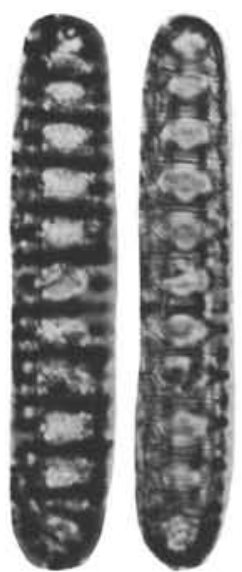

15

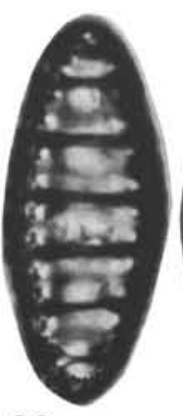

26
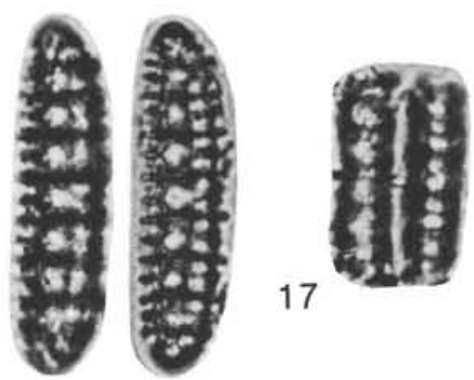

16

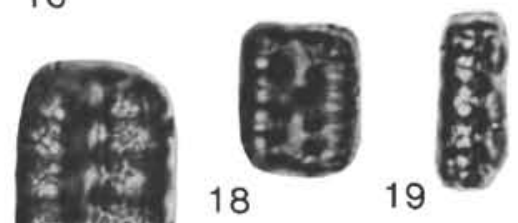

24
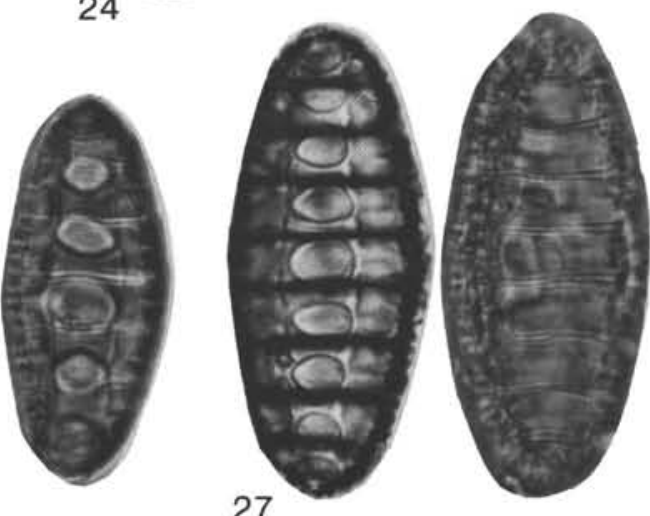

27

Plate 26. (Magnification $\times 1500$.) 1-4. Crucidenticula nicobarica (Grunow) Akiba and Yanagisawa, Sample 438A-66-2, 82-84 cm, (1-2) frustule. 5-6. Crucidenticula cf. kanayae Akiba and Yanagisawa, (5) Sample 438A-51-7, 10-11 cm, (6) Sample 438A-58-3, 19-21 cm. 7. Crucidenticula paranicobarica Akiba and Yanagisawa, Sample 584-64,CC. 8. Denticulopsis praedimorpha Barron ex Akiba, Sample 584-91-1, 70-71 $\mathrm{cm}$, primitive form. 9. Denticulopsis dimorpha (Schrader) Simonsen, Sample 584A-H2,CC. 10-14. Denticulopsis praelauta Akiba and Koizumi n. sp., Sample 439-8-6, 49-52 cm, (10) holotype. 15-19. Denticulopsis lauta (Bailey) Simonsen, (15) Sample 584-95, CC, (16-17, 19) Sample 438A-70-7, 5-7 cm, (18) Sample 584-94-1, 69-70 cm. 20-25. Denticulopsis hyalina (Schrader) Simonsen, (20-21, 23) Sample 438A-67-1, 112-113 cm, $(22,24-25)$ Sample 584A-H4,CC. (23-24) frustule, note coarse aroliert-punctae on mantle. 26-27. Denticulopsis miocenica (Schrader) Simonsen, Sample 584A-H4,CC. 

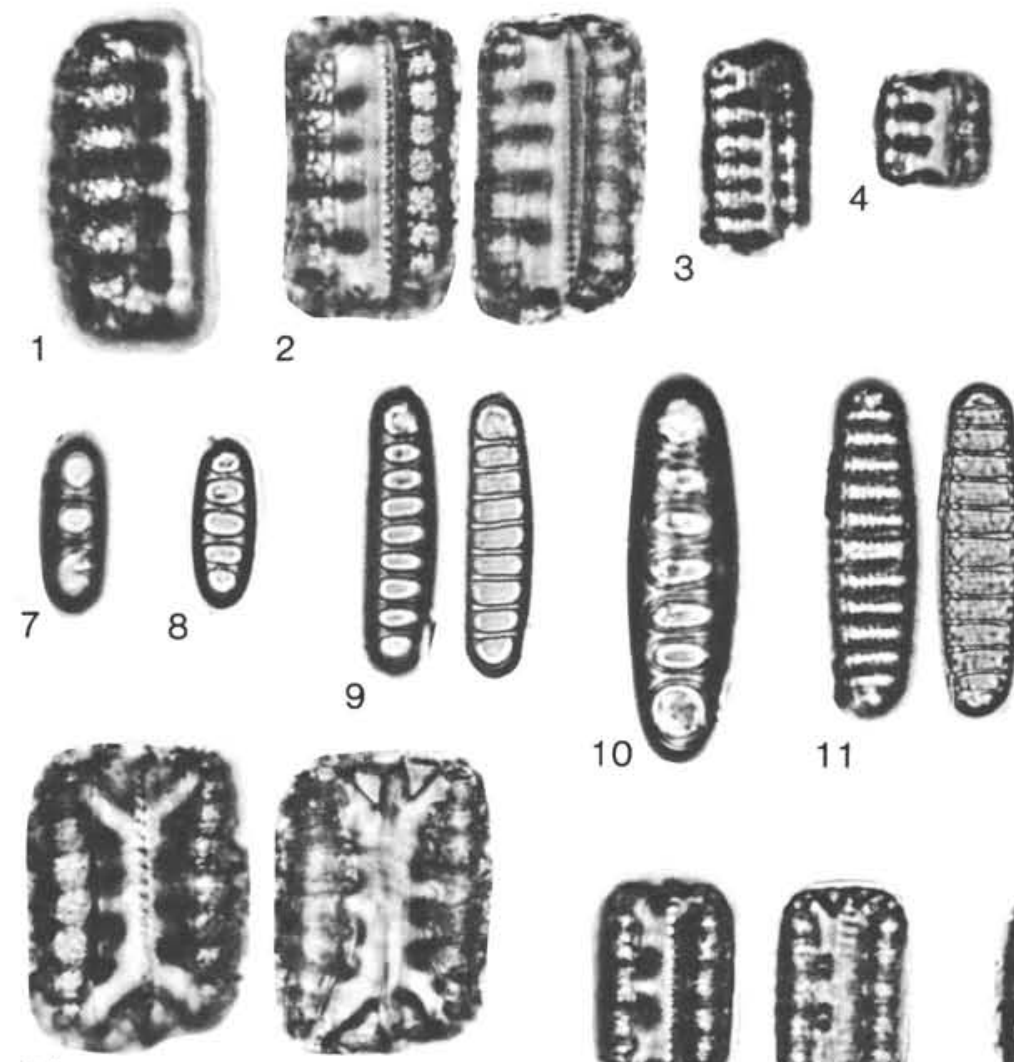

14

19
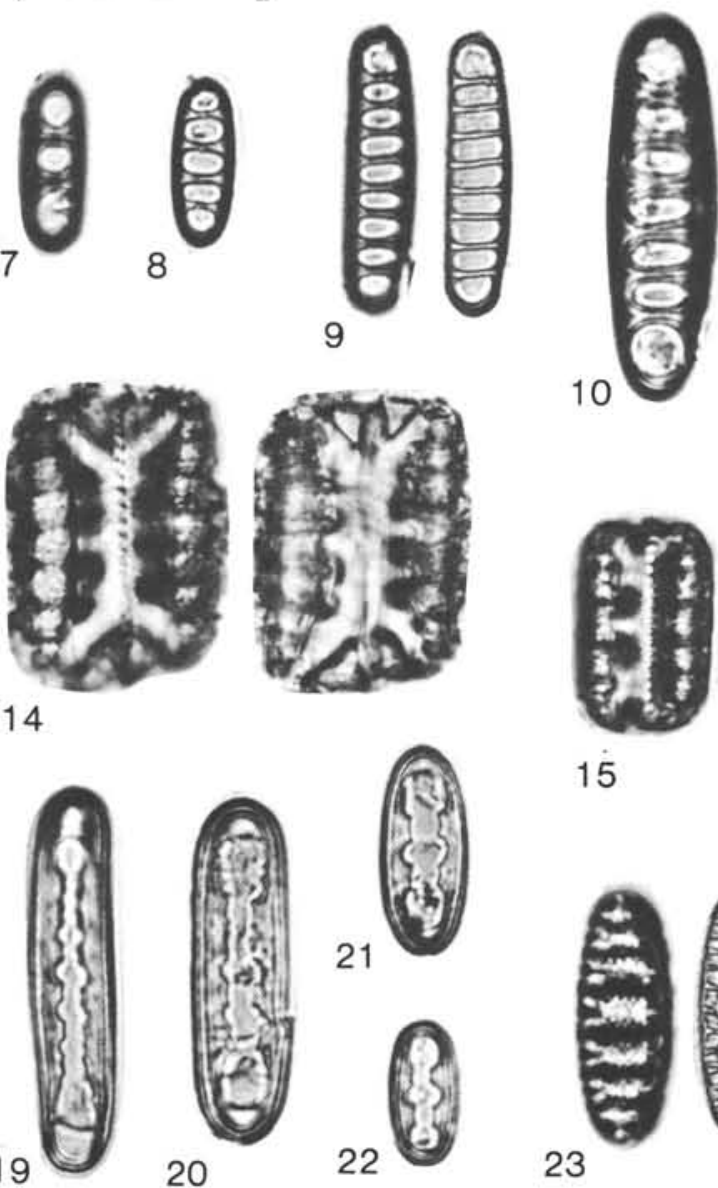

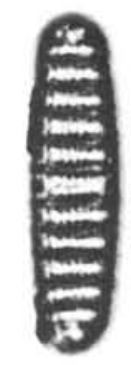

11

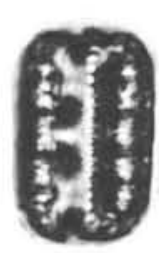

15

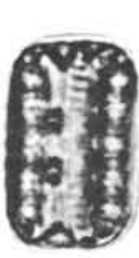

16

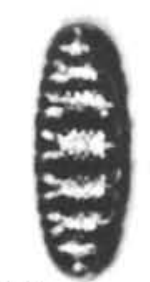

23

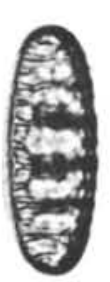

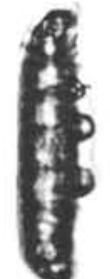

24

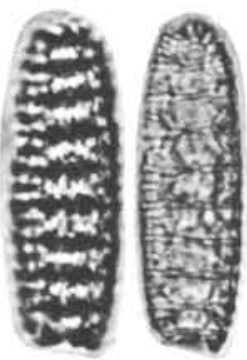

5
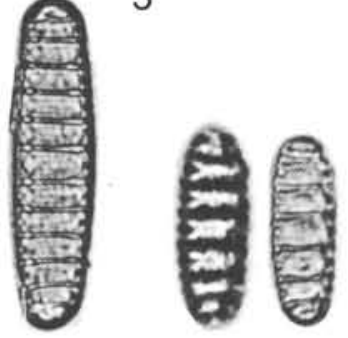

12

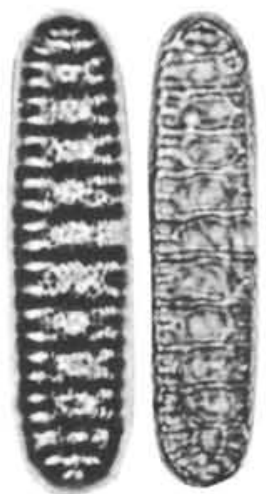

6

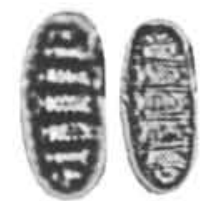

13

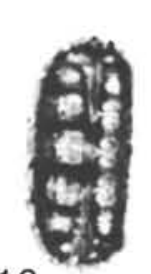

17
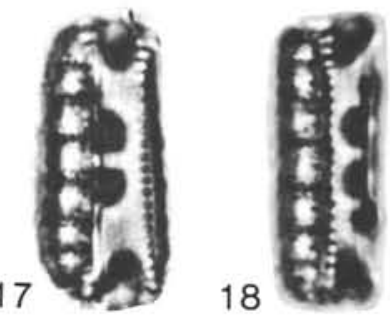

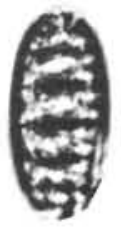

25
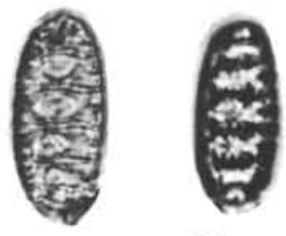

26

Plate 27. (Magnification $\times 1500$.) 1-13. Denticulopsis dimorpha (Schrader) Simonsen, Sample 438A-56,CC, (1) valve in girdle view, (2-4) frustules, (5-6) valve with coarse areoliert-punctae, (7-10) isolated intercalary band, (11-13) valve with fine punctae. 14-26. Denticulopsis praedimorpha Barron ex Akiba, (14) Sample 584-83-3, 139-140 cm, (15-26) Sample 438A-64-7, 34-35 cm, (14-16) frustule, (17-18) theca in girdle view, $(19-22)$ isolated intercalary band, (23-24) valve with well-developed crossbars, (25-26) valve with poorly developed crossbars. 

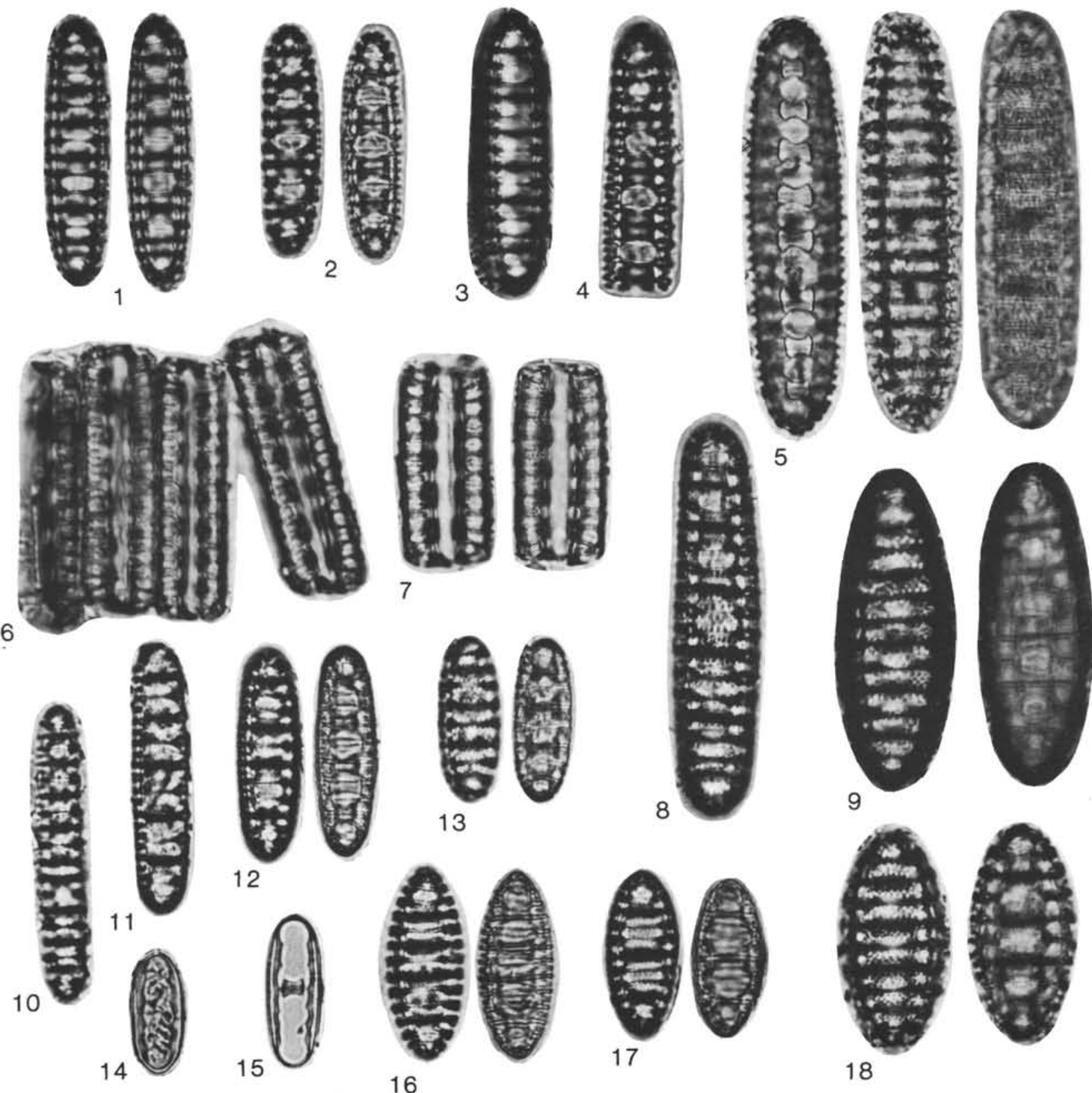

18

Plate 28. (Magnification $\times 1500$.) 1-4. Denticulopsis katayamae Maruyama, (1-2) Sample 438A-56,CC, (3) Sample 438A-53-2, 30-31 cm, (4) Sample 192-24,CC. 5-18. Denticulopsis hustedtii (Simonsen and Kanaya) Simonsen, $(5,15,18)$ Sample 438A-65-7, 17-18 cm, (6) Sample 584-76,CC, colony of four cells, (7, 11, 13) Sample 438A-66-2, 82-84 cm, (8) Sample 192-24,CC, (9) Sample 584-68,CC, (10) Sample 584-91-1, $70-71 \mathrm{~cm},(12,14,16-17)$ Sample 438A-60-3, 26-27 cm, (14-15) isolated intercalary band. 


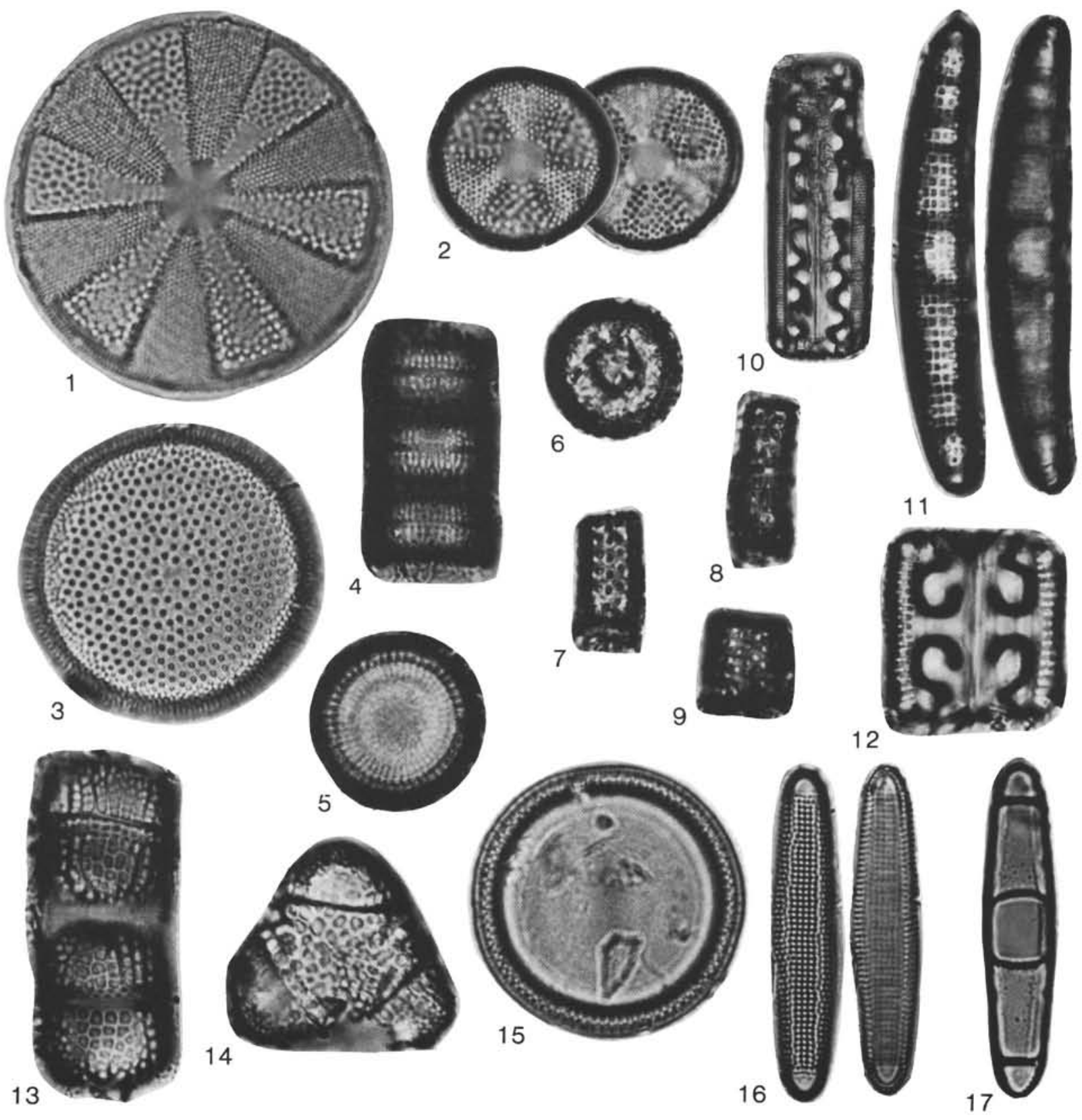

Plate 29. (Magnification $\times 1500$; Fig. $10, \times 600$.) 1. Actinoptychus vulgaris Schumann, Sample $582-1-1,34-36 \mathrm{~cm} . \quad 2$. Actinoptychus senarius (Ehrenberg) Ehrenberg, Sample 584-1-1, 0-3 cm. 4-5. Paralia sulcata (Ehrenberg) Cleve, (4) colony, Sample 584-33,CC, (5) Sample 439-17-3, 12-13 cm. 6-9. Aulacosira granulata (Ehrenberg) Simonsen s.1., Sample 439-18-3, 53-55 cm. 10. Grammatophora angulosa Ehrenberg, Sample 584-33,CC. 11. Grammatophora arcuata Ehrenberg, Sample 584-10,CC. 12. Grammatophora hamulifera Kützing, Sample 584-3,CC. 13-14. Triceratium alternans Bailey, Sample 584-27,CC, (13) colony. 15. Hyalodiscus obsoletus Sheshukova-Poretzkaya, Sample 438A-56,CC. 16-17. Grammatophora cf. oceanica (Ehrenberg) Grunow, Sample 583-4-1, 47-48 cm, (16) isolated valve, (17) isolated connecting band. 

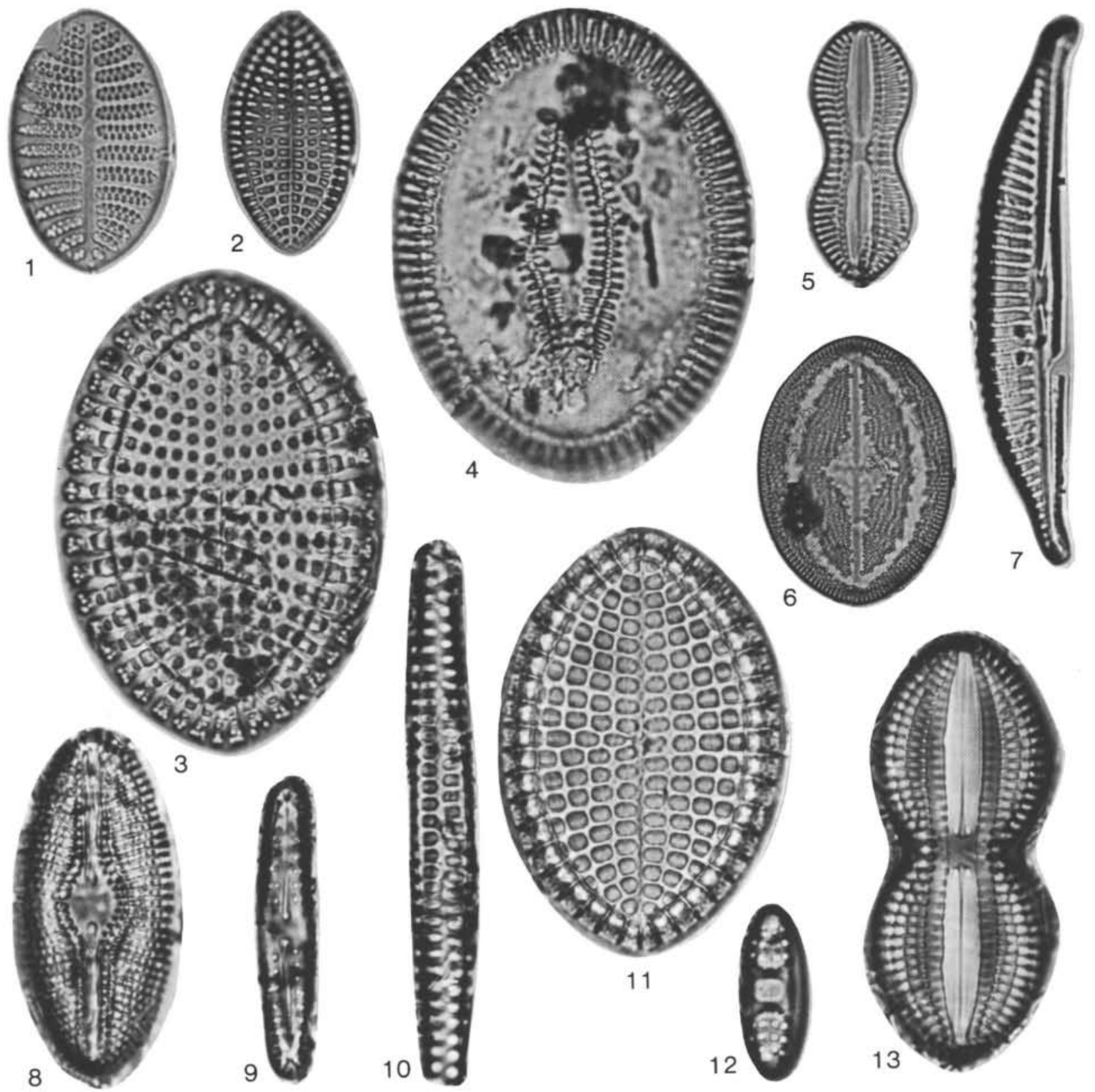